\title{
TUBERCULOSE HUMANA CAUSADA PELO Mycobacterium bovis: CONSIDERAÇÕES GERAIS E A IMPORTÂNCIA DOS RESERVATÓRIOS ANIMAIS.
}

REGINA MAURA CABRAL DE MELO ABRAHÃO

Dissertação apresentada à Faculdade de Saúde Pública da Universidade de São Paulo para obtenção do Título de Mestre em Saúde Pública.

Área de concentração:

Epidemiologia

ORIENTADOR: PROF. DR. RINALDO NIERO

São Paulo

1998 
O que for a profundeza do teu ser, assim será

teu desejo.

O que for o teu desejo, assim será tua vontade.

O que for a tua vontade, assim serão teus atos.

O que forem teus atos, assim será teu destino.

Brihadaranyaka Upanishad IV, 4.5 
Aos meus pais e irmãos, por existirem.

Ao Sergio, razão da minha vida.

À Isadora, fruto de um grande amor. 


\section{AGRADECIMENTOS}

A todos que, direta ou indiretamente, contribuíram para a realização deste trabalho:

Ao Prof. Assoc. Rinaldo Niero, pelo incentivo e orientação recebida.

Ao Prof. Dr. Péricles Alves Nogueira, pela compreensão e apoio constantes.

A todos os docentes da área de Tisiologia da Faculdade de Saúde Pública da USP.

Às funcionárias do Laboratório de Micobactérias da Faculdade de Saúde Pública da USP, Ana Lúcia e Lúcia Maria, pela amizade e cooperação nas tarefas laboratoriais.

Às funcionárias da Biblioteca da Faculdade de Saúde Pública da USP: Maria do Carmo Avamilano Alvarez, pela busca dos artigos nas bases de dados da biblioteca; Suely de Olim Santos, pela aquisição de artigos pertencentes à outras Universidades nacionais e internacionais e, especialmente, à Maria Lúcia de Faria Ferraz, pela valiosa contribuição na revisão bibliográfica.

À Dra. Sonia Regina Pinheiro, da Faculdade de Medicina Veterinária e Zootecnia da USP, pelo fornecimento de artigos científicos referentes à tuberculose bovina, e pelos esclarecimentos veterinários.

À Dra. Eliana Roxo, pesquisadora científica do Instituto Biológico da Secretaria de Agricultura do Estado de São Paulo, pelo fornecimento de relevantes artigos científicos.

À Dra. Maria Ivette Carboni Malucelli do Instituto Butantan, pela amizade e importantes sugestões no decorrer deste trabalho.

À Denise Cristina Duarte, pela amizade e apoio técnico na área de informática.

À Maria Alice, Sueli, Maria Conceição, Lucilaine e Melissa, do Setor de Micobactérias do Instituto Adolfo Lutz, pela valiosa contribuição na aquisição de bibliografias. 


\section{RESUMO}

Visando conhecer os dados epidemiológicos, a etiologia, patogenia, recursos diagnósticos, mecanismos de transmissão, tratamento, prevenção e controle da tuberculose causada pelo Mycobacterium bovis no homem, bovinos e reservatórios animais, realizou-se essa revisão bibliográfica para rever a situação da tuberculose humana causada por essa micobactéria, em termos mundiais, uma vez que os dados disponíveis no Brasil são precários. Constatou-se a grande preocupação de que a pandemia HIV/AIDS aumente o número de casos de tuberculose humana causada por M.bovis, a exemplo do que ocorreu nos casos de tuberculose humana por M.tuberculosis. Analisou-se detalhadamente os principais reservatórios animais de M. bovis existentes, com destaque àqueles de maior importância na transmissão da tuberculose humana e animal devida a este agente. Verificou-se os mecanismos de transmissão conhecidos em sua cadeia de hospedeiros, uma das mais amplas entre todos os patógenos existentes. Constatou-se os avanços das técnicas diagnósticas no campo da biologia molecular, visando uma melhor discriminação das cepas de M.bovis e M.tuberculosis. Foram abordados os problemas causados por tratamentos inadequados com drogas antituberculosas, os quais podem induzir o aparecimento de cepas multidroga-resistentes. Evidenciou-se uma urgente necessidade de maiores pesquisas sobre o desempenho de testes diagnósticos usados nos programas de controle e também para as questões de vacinação e quimioterapia. A efetiva colaboração entre a tríade microbiologistas médicos e veterinários e profissionais de saúde pública, torna-se essencial para a investigação dessa micobactéria de importância histórica e contemporânea. Existe, portanto, a necessidade de uma política de aporte de recursos materiais, humanos e financeiros, que envolvam uma cooperação internacional de órgãos vinculados à saúde pública, corroborando as recomendações da Organização Mundial da Saúde, divulgadas em Genebra em 1993. 


\section{SUMMARY}

Seeking to know the epidemic data, etiology, pathogeny, diagnostics resources, transmission mechanisms, treatment, prevention and control of the tuberculosis caused by the Mycobacterium bovis in man, bovine and animal reservoirs, it took place this bibliographical revision to review the situation of the human tuberculosis caused by that mycobacteria worldwide, since there are few available data in Brazil. There is a great concern whether the pandemic HIV/AIDS will increase the number of cases of human tuberculosis caused by M.bovis, as occurred due to Mycobacterium tuberculosis. It was analyzed the main animal reservoirs of M.bovis existent in full detail, with emphasis to those of larger importance in the transmission of the human and animal tuberculosis due to this agent. The transmission mechanisms were verified in its hosts chain, one of the widest among all the existent pathogens. The progress of the diagnostic technics in the field of the molecular biology, seeking a better strains discrimination of M.bovis and M.tuberculosis was evidenced. The problems caused by inadequate treatments with antituberculosis drugs, which can induce the appearing of multidrug-resistants strains, were approached. An urgent need of larger researches was evidenced on the performance of diagnostics tests used in the control programs and, also, for the vaccination subjects and chemotherapy. The effective collaboration between the triad medical and veterinary microbiologists and professionals of public health, is essential for the investigation of that mycobacteria of historical and contemporary importance. There is, therefore, the need of a material, human and financial resources policy, involving international cooperation of organs linked to the public health, corroborating the recommendations of World Health Organization, published in Geneva in 1993. 


\section{ÍNDICE}

1- INTRODUÇÃO

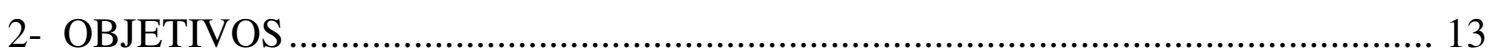

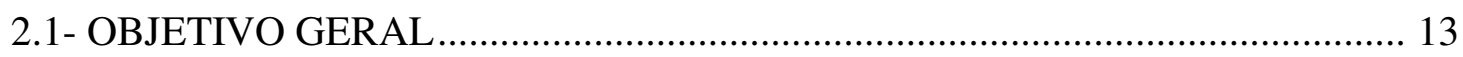

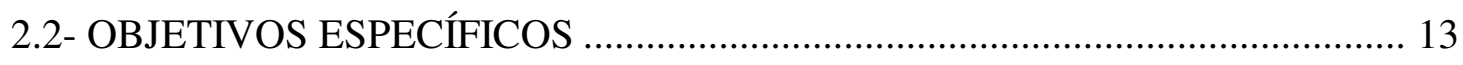

3- PROCEDIMENTOS METODOLÓGICOS …………………………………........ 14

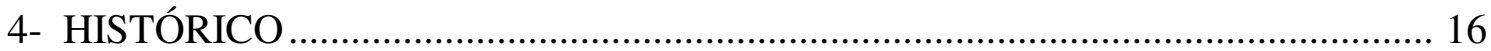

5- EPIDEMIOLOGIA DA TUBERCULOSE CAUSADA PELO Mycobacterium

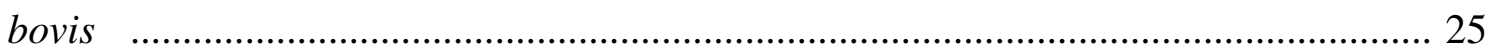

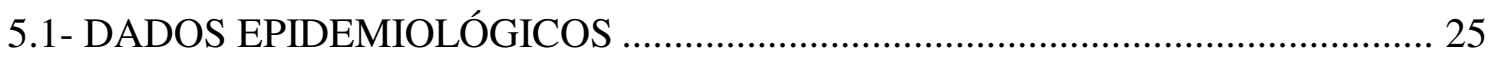

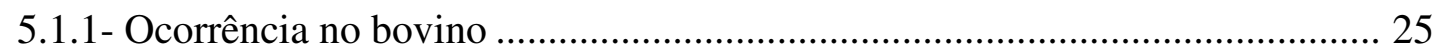

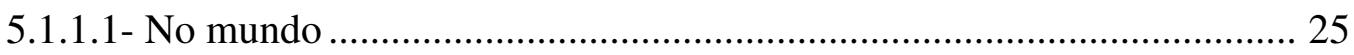

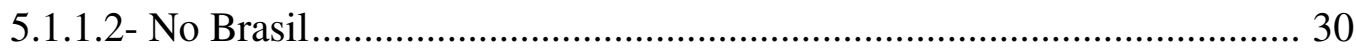

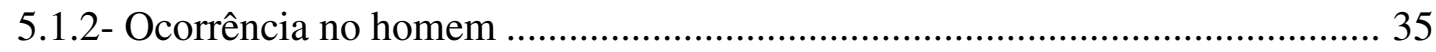

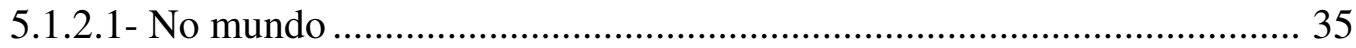

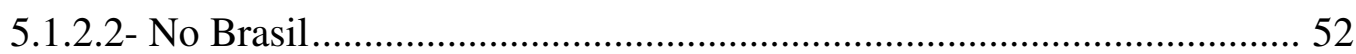

5.1.3- Ocorrência nos reservatórios animais ............................................................ 52

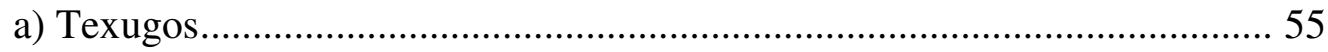

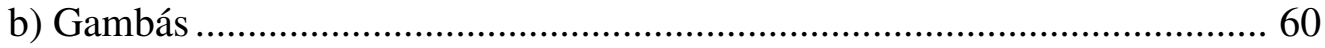

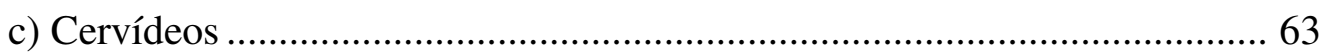

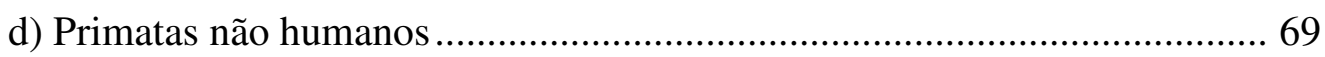

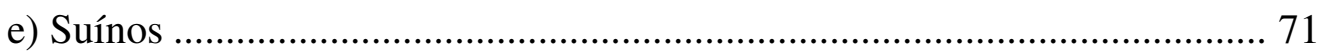

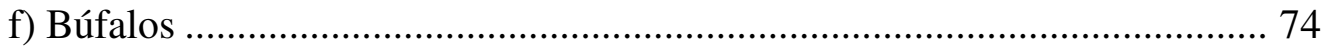

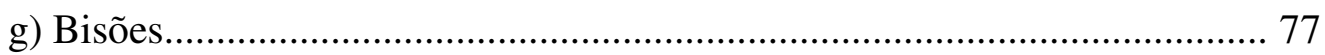

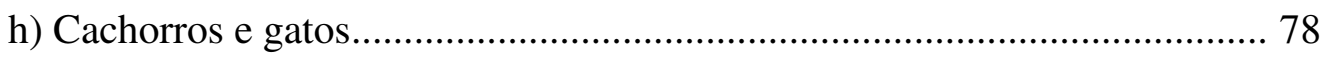

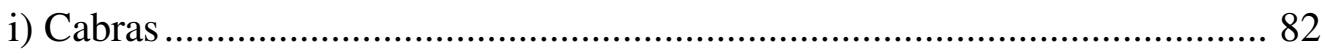

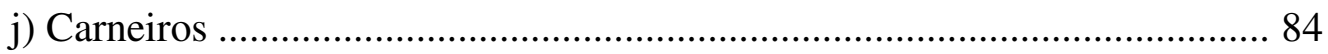

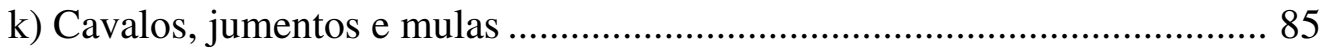

1) Camelos e outros animais de casco .......................................................... 87

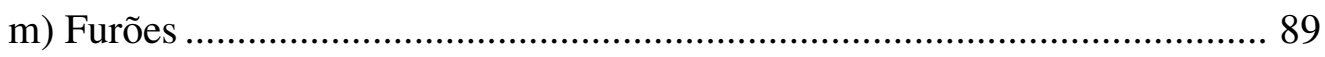

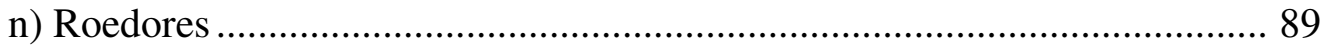




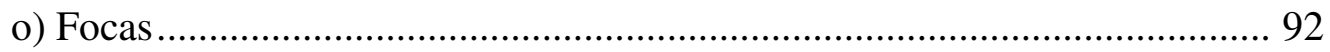

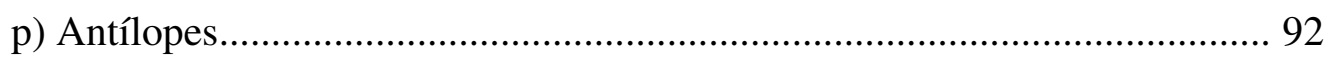

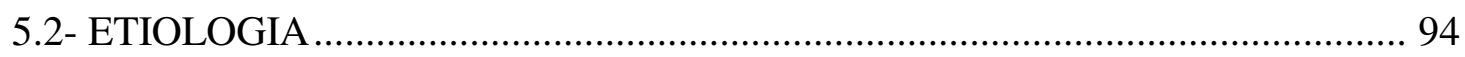

5.2.1- Agente etiológico..................................................................................... 94

5.2.2- Características morfológicas, tintoriais e de cultivo........................................ 95

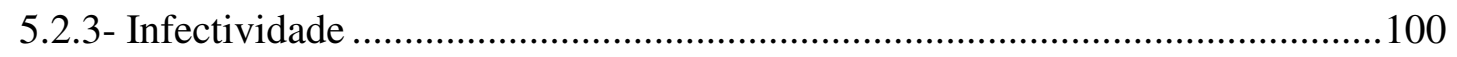

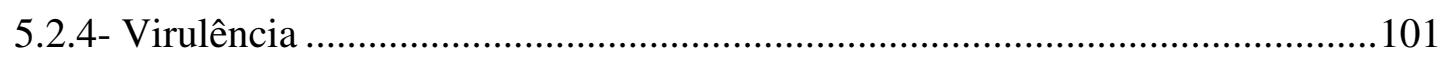

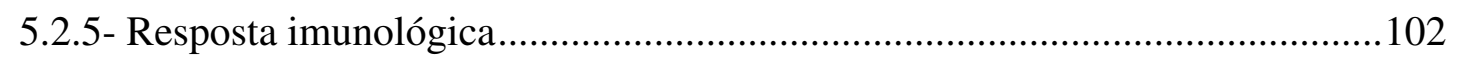

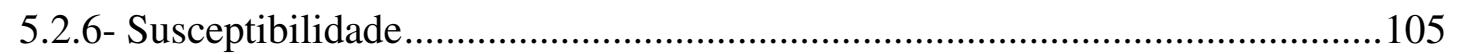

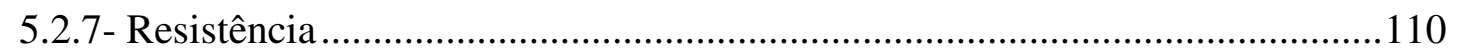

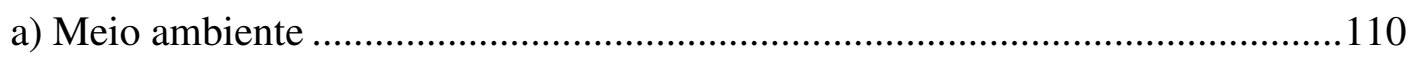

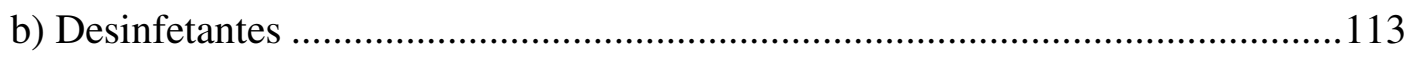

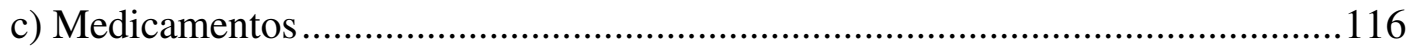

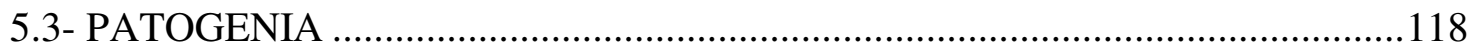

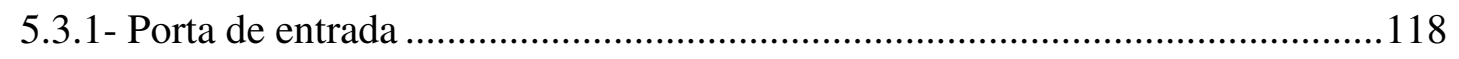

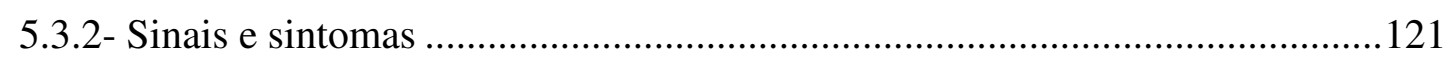

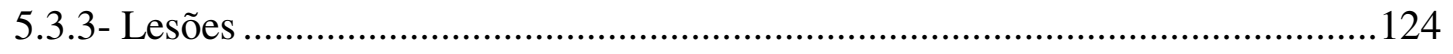

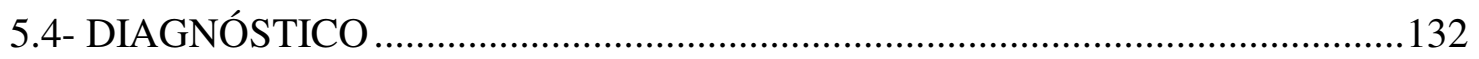

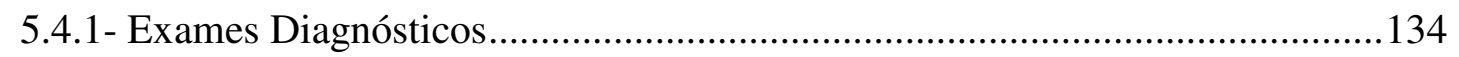

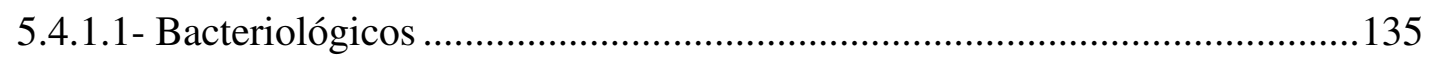

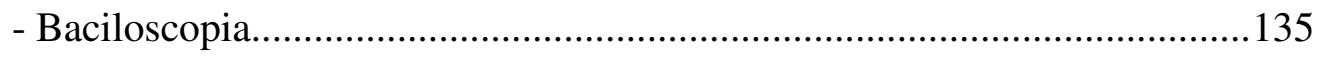

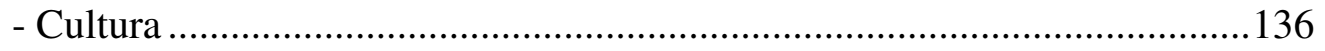

- Inoculação em animais ...............................................................................139

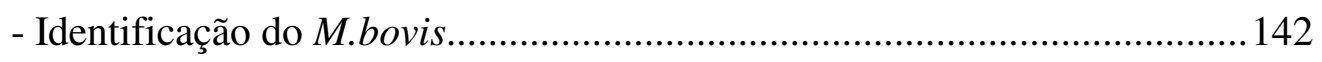

- Teste de sensibilidade aos tuberculostáticos ..............................................146

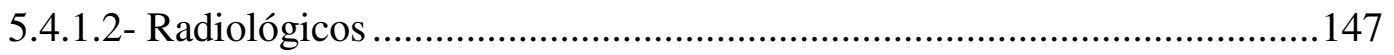

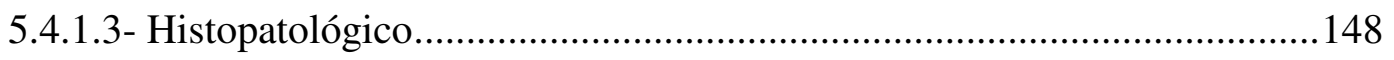

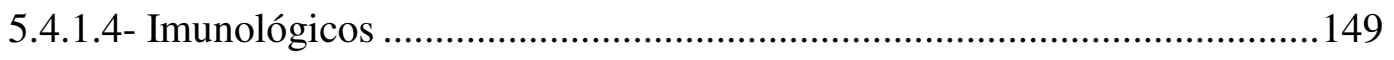

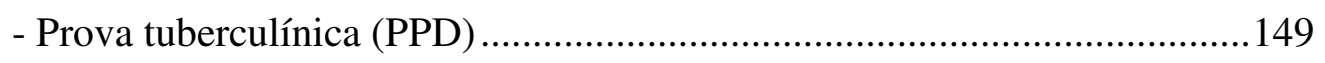

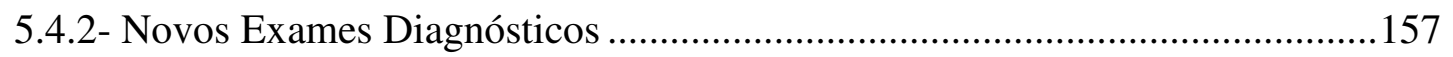

5.4.2.1- Método radiométrico (BACTEC) ..........................................................158

5.4.2.2- Cromatografia gás-líquida ..................................................................... 159 
5.4.2.3- Métodos sorológicos.

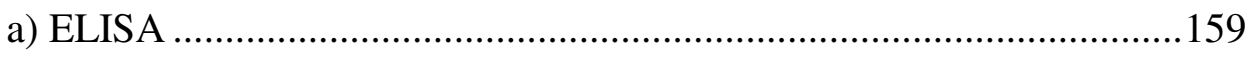

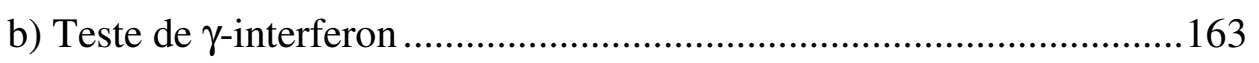

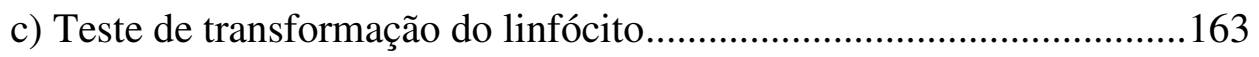

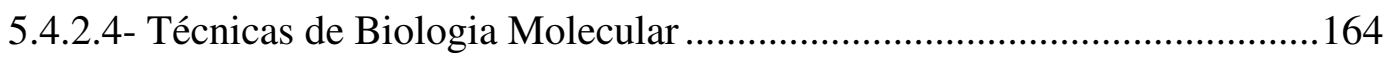

a) Separação eletroforética de moléculas e transferência para fase

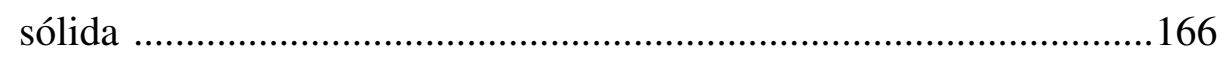

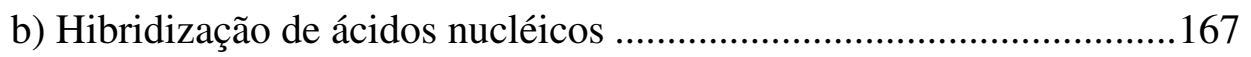

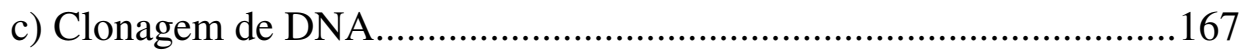

d) RFLP e Endonucleases de restrição..................................................169

e) Análise da endonuclease de restrição (REA) ...................................174

f) PCR (Reação em cadeia da polimerase)..........................................177

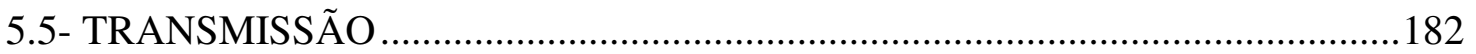

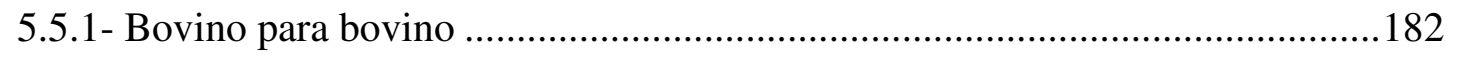

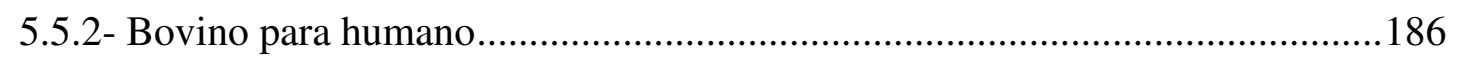

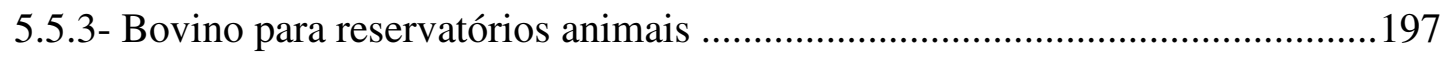

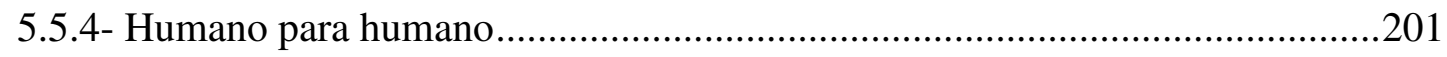

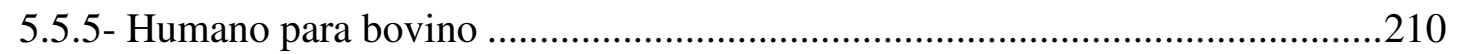

5.5.6- Humano para reservatórios animais ..........................................................213

5.5.7- Reservatórios animais para reservatórios animais .......................................215

5.5.8- Reservatórios animais para humanos ………................................................229

5.5.9- Reservatórios animais para bovinos ……....................................................22

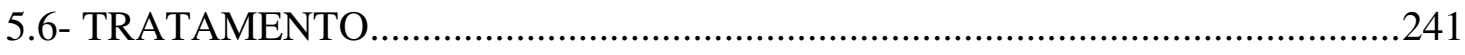

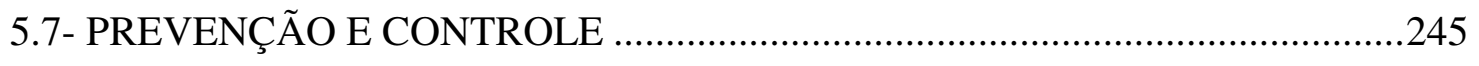

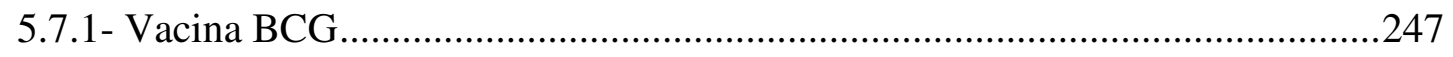

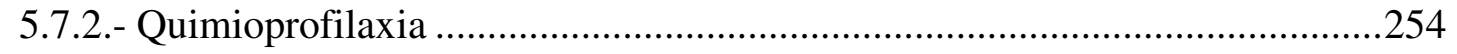

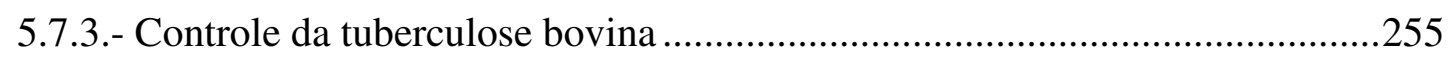

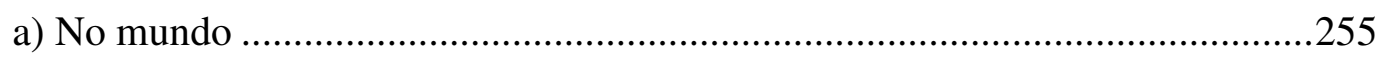

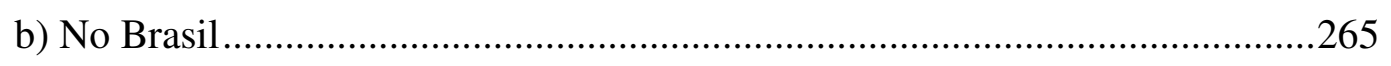

5.7.4- Controle da tuberculose por M.bovis nos animais domésticos e selvagens....273

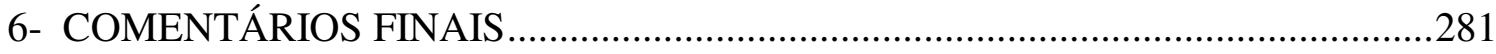

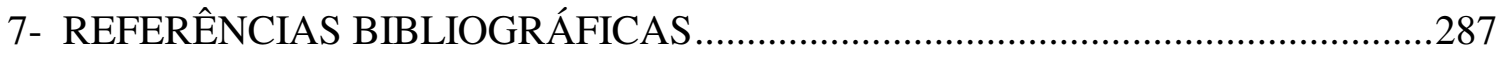




\section{LISTA DE SIGLAS E ABREVIAÇÕES}

$\mu=$ micra

$\mu \mathrm{g}=$ microgramas

$\mathrm{mg}=$ miligramas

$\mathrm{g}=$ gramas

$\mathrm{kg}=$ quilogramas

$\mathrm{ml}=$ mililitros

$\mathrm{mm}^{3}=$ milímetros cúbicos

$\mathrm{cm}=$ centímetros

$\mathrm{pH}=$ Potencial hidrogênico

BCG = Bacille Calmette-Guérin

$\mathrm{BAAR}=$ Bacilo álcool-ácido resistente

AIDS = Síndrome da Imunodeficiência Adquirida (sigla de "Acquired Immuno

Deficiency Syndrome")

HIV = Vírus da Imunodeficiência Humana (sigla de "Human Immunodeficiency

Virus")

BIV = Vírus da Imunodeficiência bovina ( sigla de "Bovine Immunodeficiency-like Virus")

MOTT $=$ Mycobacteria other than Mycobacterium tuberculosis

OMS = Organização Mundial da Saúde

WHO = World Health Organization

OPAS = Organização Panamericana de Saúde

MAFF $=$ Ministry of Agriculture, Fisheries and Food

NWRC $=$ National Wildlife Research Center

$\mathrm{CDC}=$ Center for Disease Control

MDR = Multidrug-resistant

PPD $=$ Derivado Protéico Purificado

$\mathrm{VL}=$ Visible lesions

$\mathrm{NVL}=$ No visible lesions 


\section{1- INTRODUÇÃO}

A atualidade da questão da tuberculose é indiscutível, dado o aumento do número de casos no mundo, associado à pobreza crescente e epidemia de AIDS ${ }^{192}$. Os avanços no seu conhecimento e a tecnologia disponível para seu controle, não têm sido suficientes para impactar significativamente a sua morbidade e mortalidade, principalmente nos países em desenvolvimento ${ }^{193}$.

O gênero Mycobacterium (do grego mycos: fungo) inclui parasitas obrigatórios, saprófitas e formas intermediárias. Contem mais de 50 espécies, entre as quais pelo menos 22 podem causar doença no homem, destacando-se as incluídas no complexo Mycobacterium tuberculosis (M.tuberculosis, M.bovis, M.africanum (isolado de humanos na África equatorial) e M.microti) e o M.leprae, pelo fato de serem patogênicas para o homem. Os autores incluem o M.microti apesar dessa micobactéria ser uma exceção, porque é patogênica apenas para o arganaz (ratazana Microtus agrestis) e outros pequenos roedores e não para o homem. Alguns autores incluem também a cepa BCG no complexo M.tuberculosis 17, 32, 34, 50, 68, 89, 92, 93, 104, 117, 125, 126, 127, 128, 142, 191, 201, 216, 228, 236, 252, 254, 261, 277, 290, 295, 296, 297.

As espécies de micobactérias altamente patogênicas são parasitas facultativa ou obrigatoriamente intracelulares, entretanto, muitas micobactérias saprófitas também agem como patógenos oportunistas. As espécies potencialmente patogênicas, largamente disseminadas na natureza (no solo, água, aves e animais domésticos e silvestres), já receberam nomenclaturas distintas, como "atípicas", "anônimas", "não classificadas", "não tuberculosas", "oportunistas" e hoje são comumente denominadas MOTT, ou seja, outras que não especificamente o M.tuberculosis $32,53,89,142,228,236,240,290,297,240$.

Em 1959, Runyon propôs uma divisão das micobactérias baseando-se em duas características culturais: o tempo de crescimento e a produção de pigmento, separando-as em 4 grupos que não incluíam as espécies típicas como o M.tuberculosis, M.bovis, M.avium e as não cultiváveis como o M.leprae. Esta primeira classificação, ainda que superada em profundidade e detalhe, tem utilidade como guia, especialmente para o bacteriólogo clínico e o médico ${ }^{53,192}$. 
Em 1974, Runyon publicou a lista dos "patógenos micobacterianos" para o homem, que incluíam as seguintes espécies: M.leprae, M.ulcerans, complexo M.tuberculosis, M.kansasii, M.marinum, M.simiae, M.szulgai, complexo M.aviumscrofulaceum, M.xenopi e complexo M.fortuitum ${ }^{53}$.

Muitos esquemas de classificação dessas micobactérias já foram propostos por vários pesquisadores, entre os quais Tsukamura, que em 1967 propôs a separação de micobactérias de crescimento rápido em um novo sub-gênero denominado Mycomycobacterium, mas essa divisão não foi $\operatorname{adotada}^{32}$. Wolinsky $(1979)^{290} \mathrm{e}$ Bergey $(1986)^{32}$ classificaram as MOTT em patógenos e não patógenos humanos de maneira semelhante e de acordo com o tempo de crescimento dessas micobactérias em meios de cultura. Bergey $(1986)^{32}$ dividiu-as em 2 grupos: as de crescimento lento (mais de 7 dias) e as de crescimento rápido (igual ou inferior a 7 dias) $32,142,236,290$.

No grupo de crescimento lento estão enquadradas várias espécies patogênicas, destacando-se o M.avium e M.intracellulare que não podem ser diferenciados através de testes de identificação rotineiramente usados em laboratórios clínicos e, consequentemente, são referidos como complexo M.avium (MAC-Mycobacterium avium complex). Também pertencem a este grupo o M.scrofulaceum, M.kansasii, M.ulcerans, M.marinum, M.xenopi, M.malmoense; outras eventualmente patogênicas como o M.asiaticum, M.shimodei, M.szulgai, M.gordonae, M.simiae; além do complexo M.terrae, que inclui o M.terrae (patógeno eventual), M.nonchromogenicum e M.triviale. O M.triviale e o M.gastri são micobactérias de patogenicidade ainda não demonstrada ${ }^{32,142,236,290}$.

No grupo de crescimento rápido, são descritas mais de 25 espécies, tais como M.thermoresistibile, M.flavescens, M.gadium, M.aichiense, M.obuense, encontradas principalmente na expectoração e/ou lavado gástrico, para as quais não foi demonstrado qualquer poder patológico. A micobactéria saprófita de conhecimento mais antigo e que até hoje convive com o homem sem causar danos é o M.smegmatis, freqüente no esmegma. Neste grupo destacam-se ainda, do ponto de vista clínico e pela patogenicidade, o M.fortuitum e M.chelonae, referidos como complexo 
M.fortuitum $32,142,236,290$.

As MOTT mais isoladas no Brasil são o complexo M.avium, M.fortuitum, M.kansasii, M.chelonae e M.scrofulaceum, e causam principalmente doença pulmonar e ganglionar. Essas e outras formas têm sido encontradas em pacientes soropositivos para o vírus da imunodeficiência humana (HIV), sendo que esse grupo contribui hoje com a metade da casuística das micobactérias no Brasil ${ }^{192}$.

A tuberculose era chamada "peste branca" por ter alcançado proporções epidêmicas durante a Revolução Industrial, e por ter matado mais de um bilhão de pessoas nos últimos 200 anos ${ }^{50,71}$.

Três espécies animais perpetuaram a tuberculose através dos séculos: o homem, o bovino e as aves em geral, contribuindo assim para a manutenção destes bacilos na natureza $136,201,272$.

O termo tuberculose deve ser reservado para designar a doença causada pelo M.tuberculosis, M.bovis e M.avium, agentes etiológicos da tuberculose humana, bovina e aviária, respectivamente; enquanto as outras micobactérias (MOTT) causam doenças que hoje são referidas como micobacterioses 116, 201, 204, 225, 267, 281, 282 . Por isso, nos casos suspeitos de tuberculose não se deve perder de vista a possibilidade de infecção por animais, pois todos são sensíveis a um dos três tipos de bacilo ${ }^{4}$.

Em 1981, a síndrome de imunodeficiência adquirida (AIDS) foi reconhecida pela primeira vez como uma nova doença, resultante da infecção crônica de vários tipos de células por um retrovírus, o vírus da imunodeficiência humana (HIV), identificado como seu agente causal em 1983. O impacto da infecção pelo HIV sobre a situação da tuberculose se fez notar, mundialmente, no aumento do número de casos de tuberculose ativa, uma vez que a tuberculose é uma importante manifestação da imunodeficiência induzida pelo HIV 16, 89, 111, 121, 142, 236, 299.

Segundo estimativas realizadas pela Organização Mundial da Saúde, um terço da população mundial está infectada pelo Mycobacterium tuberculosis, sendo que durante a década de 1990-1999, ocorrerão no mundo 88 milhões de casos novos de tuberculose, dos quais, 8 milhões serão atribuídos à infecção pelo HIV 50, 89, 111, 121, 
142, 230, 295, 296, 299, 300 . A previsão é de que 30 milhões de pessoas morram de tuberculose no mesmo período, incluindo 2.9 milhões $(9.7 \%)$, devido à infecção pelo HIV 50, 101, 121, 193, 216, 230, 295.

No sudeste da Ásia, dos 35.1 milhões de casos novos de tuberculose que são esperados durante a década, 2.8 milhões (8\%) serão atribuídos ao HIV, e dos 15 milhões de casos estimados para a África sub-Sahara durante o mesmo período, 3.9 milhões $(25 \%)$ serão atribuídos à infecção pelo HIV ${ }^{101,121}$.

Estima-se também, que o número de casos novos de tuberculose que ocorrem a cada ano no mundo, aumentará de 7,5 milhões (143 casos por 100.000 habitantes) em 1990 para 8,8 milhões (152 por 100.000) em 1995 e 10,2 milhões (163 por 100.000) no ano 2000, correspondendo a um aumento de $36 \%$ 101, 161, 230, 295, 296, 300. Projeções feitas em 1995 indicaram que no ano 2005 ocorrerão 11.9 milhões de casos novos de tuberculose, anualmente ${ }^{230}$.

A incidência específica por idade para os anos 1990 e 2000 demonstra que $70 \%$ dos casos novos ocorrem entre 15 e 59 anos (quando as pessoas são economicamente mais produtivas), $20 \%$ com no mínimo 60 anos e $10 \%$ inferior a 15 anos $101,161,230$.

Em 1990 aproximadamente 2,5 milhões de pessoas morreram de tuberculose, tornando esta doença a maior causa de morte por um único patógeno no mundo. Em 1995 morreram aproximadamente 3,0 milhões de pessoas e estima-se que ocorrerá 3,5 milhões de mortes por tuberculose no ano $2000{ }^{101,161,230,295,296,300}$. Entretanto, apenas $4.6 \%$ de todas as mortes por tuberculose foram atribuídas à infecção pelo HIV em 1990. Estimou-se que em 1995 essa porcentagem aumentou para 8.9\% e que no ano 2000, 14.2\% das mortes por tuberculose, serão associadas ao HIV 101, 230, 300. Globalmente, 500.000 mortes por tuberculose, por ano, serão atribuídas à AIDS no ano $2000^{89,101,300 .}$

Apesar da variabilidade nos relatórios, vigilância e descoberta de casos, muitos países na África, Ásia e América do Sul, apresentam taxas de morbidade extremamente altas. Em 1990, as taxas excederam 300 casos por 100.000 habitantes 
na Zâmbia e Bolívia, e 200 por 100.000 nas Filipinas, África do Sul, Peru, Nigéria e Índia. Todas as evidências apontam para uma devastadora taxa de tuberculose em muitos países africanos. Na Tanzânia, em 1988, foram registrados 5.000 casos de tuberculose acima da média anual. No hospital rural Malawi, por exemplo, as admissões por tuberculose aumentaram $160 \%$ entre 1983 e $1988^{300}$.

A distribuição geográfica da tuberculose guarda íntima relação com os índices sócio-econômicos das diversas nações. As taxas de incidência da doença são baixas nos países desenvolvidos e muito altas naqueles países cuja população está sujeita à desnutrição e às más condições de habitação ${ }^{191,225}$.

Nos países desenvolvidos, a maioria dos casos de tuberculose está concentrada nos grandes centros urbanos, nos quais, em adição aos tradicionais fatores de risco ambientais, existe um aumento na prevalência de infecções pelo HIV e uma maior concentração de imigrantes provenientes de países em desenvolvimento $^{101,300}$. Apesar do declínio das taxas de morbidade por tuberculose nos Estados Unidos, a cidade de Nova York, em 1993, possuía uma taxa de incidência de 44.2 novos casos por 100.000 habitantes, ou seja, uma taxa $450 \%$ maior do que a nacional que era de 9.8 por 100.000 . Um estudo realizado nos Estados Unidos estimou que a imunossupressão causada pela infecção por HIV, foi responsável por aproximadamente 30\% dos novos casos de tuberculose entre 1985 e $1990^{300}$.

A associação da tuberculose com a infecção pelo HIV talvez se constitua senão na mais grave, pelo menos na mais característica das associações, em termos de morbidade, por se tratar não de mera interação patológica, mas de uma combinação de fatores epidemiológicos, sociais e individuais que favorecem o desenvolvimento de ambas as condições. $\mathrm{O}$ aspecto fundamental diz respeito aos dois agentes etiológicos e à resposta imunológica mediada por células, da qual dependem igualmente para a sua evolução e, em particular, das defesas do aparelho respiratório, porta de entrada da infecção inicial pelo bacilo da tuberculose. A falência do sistema imunitário, diminuindo ou suprimindo as defesa, faz com que múltiplas infecções e certas neoplasias (sarcoma de Kaposi) se implantem facilmente no organismo, sendo 
que os pulmões são freqüentemente atingidos pelo Pneumocystis carinii, o citomegalovírus, o adenovírus ou por fungos diversos, facilitando extraordinariamente a progressão das micobactérias ${ }^{36,230,236,299}$. A infecção pelo HIV foi o maior fator a alterar o equilíbrio entre o homem e o bacilo de Koch nos últimos 100 anos ${ }^{164}$.

A AIDS está modificando dramaticamente a epidemiologia da tuberculose no homem, porque, não somente, facilita a implantação da primo-infecção tuberculosa, com formas graves, como propicia a reativação de antigos focos residuais quiescentes, isto é, abre caminho para a reativação endógena 36, 90, 127, 130, 230, 236, 299. Nas infecções com HIV, embora ainda não com AIDS doença, também há maior incidência de infecções por micobactérias ${ }^{236}$.

Em 1994, a OMS estimou que o número de pessoas infectadas pelo HIV, desde o início da pandemia, havia excedido 17 milhões, sendo que, desse total, 16 milhões de casos ocorreram em adultos e 1 milhão em crianças ${ }^{230,} 299$.

Mais recentemente, a WHO estimou que aproximadamente 5 milhões de pessoas estão infectadas com M.tuberculosis e HIV desde o início da pandemia de AIDS $89,230,299,300$, sendo que a maioria (3.8 milhões) dos co-infectados vivem na África sub-Sahara e mais que 1.15 milhões no sudeste da Ásia ${ }^{101,230}$. Na América Latina e Caribe estimou-se aproximadamente 450.000 pessoas infectadas pelo vírus HIV e tuberculose ${ }^{164,230,299}$. A tuberculose tem uma íntima ligação com a infecção pelo HIV e AIDS, e 95\% das pessoas portadoras de ambas as infecções vivem nos países em desenvolvimento $89,111,230,295,300$. No mundo todo, aproximadamente 5\% dos casos de tuberculose são relacionados ao HIV, chegando a $20 \%$ na África subSahara ${ }^{89,230}$.

Dois terços dos casos mundiais de tuberculose estão na Ásia, onde a infecção pelo HIV espalha-se mais rapidamente do que em qualquer outra parte do mundo. Em 1995, previu-se que em 10 anos a tuberculose e AIDS juntas, matarão mais pessoas na Ásia do que toda a população das cidades de Singapura, Beijing, Yokohama e Tokyo combinadas ${ }^{216}$. 
Em muitos países em desenvolvimento, a tuberculose emergiu como a doença oportunista mais comum associada à infecção pelo HIV, sendo que em 1995, acima de 54\% dos pacientes com AIDS na África, 24 a 28\% no México e em alguns países da América Latina, como o Brasil, e 23\% no Haiti, tinham tuberculose clínica durante o curso da infecção pelo HIV ${ }^{230}$.

A co-infecção com HIV tem atribuído outra dimensão ao problema da tuberculose. A transmissão hospitalar do M.tuberculosis tornou-se um sério problema na última década, entre pacientes de AIDS hospitalizados. Este problema aumentou devido ao surgimento de cepas multidroga-resistentes (MDR), que exigem terapia prolongada e aumentam o período de comunicabilidade entre os doentes ${ }^{71,117,300}$.

A maioria dos casos de tuberculose em infectados pelo HIV é causada pelo M.tuberculosis, mas casos de infecção com M.bovis e infecção com a cepa de M.bovis da vacina BCG, também têm sido descritos ${ }^{85,249}$.

No Brasil, o Programa Nacional de Controle da Tuberculose (PNCT) é um conjunto de ações integradas desenvolvidas pelos diferentes níveis de governo, com a participação da comunidade, visando modificar a situação epidemiológica através da redução da morbidade, da mortalidade e atenuar o sofrimento humano causado pela doença, mediante o uso adequado dos conhecimentos técnicos e científicos e dos recursos disponíveis e mobilizáveis, tendo como objetivo colocar a doença sob controle $^{193}$.

Os resultados atuais do Programa mostram uma cobertura vacinal de $90 \%$ dos menores de um ano, uma descoberta de $75 \%$ dos casos estimados e sucesso terapêutico em $75 \%$ dos pacientes que iniciam tratamento, configurando assim, as ações governamentais para reduzir o problema da tuberculose no Brasil. Apesar desse esforço, a tuberculose ainda persiste, ocorrendo cerca de 90.000 casos novos e mais de 5.000 mortes anuais. A redução da taxa de incidência, em $2 \%$ ao ano para a forma pulmonar positiva, embora mantida, é pouco expressiva para o controle da doença ${ }^{193}$.

Esse panorama tende a agravar-se por várias causas, destacando-se: a crise econômica que gerou bolsões de pobreza no país, a deterioração dos serviços de 
saúde, a epidemia da AIDS que aumentou o número de casos e o aparecimento de cepas resistentes às drogas usuais devido a tratamentos inadequados ou incompletos ${ }^{89,193}$. Um dos principais receios atualmente é de que a tuberculose venha a se tornar uma doença incurável como resultado do aparecimento de cepas resistentes às drogas antituberculosas ${ }^{299}$.

Em 1995, o Brasil elaborou um Plano Emergencial para o controle da tuberculose, objetivando que $100 \%$ dos municípios tenham ações de diagnóstico e tratamento, $80 \%$ dos centros de saúde desenvolvam essas ações, 90\% dos casos existentes sejam diagnosticados, e que $85 \%$ dos casos tratados sejam curados ${ }^{193}$.

A introdução do HIV em populações com alta prevalência de M.tuberculosis acrescentou um obstáculo considerável para o controle da tuberculose. Entre os casos de AIDS notificados ao Ministério da Saúde no Brasil, a frequiência da tuberculose associada à AIDS aumentou de 8\%, em 1984, para $19.9 \%$ em $1994^{113,164}$.

Em 1993, uma declaração da OMS colocou a tuberculose em "estado de emergência" em todo o mundo ${ }^{50,193,230}$. Esta declaração e o anúncio de sua magnitude na próxima década valeram como um chamado a todos os países, para que superassem a negligência que tem caracterizado as ações governamentais nesse campo, retomassem o esforço concentrado de outras épocas e pusessem em ação a tecnologia que está disponível. Essa tecnologia, adequadamente utilizada, seria capaz de reverter a ameaça que a tuberculose representa atualmente para países desenvolvidos e em desenvolvimento ${ }^{193}$. A World Health Assembly endossou que os objetivos para o controle global da tuberculose são: a cura de pelo menos $85 \%$ dos casos recentemente detectados e a detecção de pelo menos $70 \%$ dos casos existentes até o ano $2000^{230}$.

Outra preocupação da OMS foi a considerável e contínua importância em saúde pública da infecção pelo Mycobacterium bovis no ser humano e animais ${ }^{296}$. O M.bovis, conhecido de outra maneira como bacilo da tuberculose bovina, é a causa da tuberculose bovina. Este último termo deveria ser utilizado estritamente para se referir à tuberculose no bovino, mas ele é muitas vezes usado para denominar a tuberculose causada pelas cepas bovinas do bacilo da tuberculose, 
independentemente do hospedeiro ${ }^{125,216}$. De fato, o bacilo da tuberculose bovina tem uma das mais amplas cadeias de hospedeiros entre todos os patógenos conhecidos $^{125,199,216}$.

A tuberculose humana e animal causada por esse agente já é conhecida desde o final do século XIX ${ }^{81}$. Entretanto, seus efeitos na produtividade dos rebanhos afetados e na saúde humana, tornaram-se aparentes somente no início do século XX com o desenvolvimento da indústria leiteira na Europa e América ${ }^{156}$. Devido à falta de conhecimento a respeito do agente causal, da epidemiologia da doença e da conexão entre casos humanos e animais, pouco foi feito para controlar o problema até o início do século ${ }^{49}$.

A tuberculose bovina é uma zoonose (doenças ou infecções naturalmente transmissíveis entre os animais vertebrados e o homem) ${ }^{255}$ de evolução crônica e efeito debilitante, causada pelo Mycobacterium bovis, que é também um bacilo álcool-ácido resistente (BAAR). Esta enfermidade é caracterizada pela formação de lesão do tipo granulomatoso, de aspecto nodular, denominada "tubérculo", cujo hospedeiro primário é o bovino 20,55, 74, 115, 201, 237, 282 . Diversas espécies mamíferas, incluindo o homem, são também susceptíveis ao bacilo bovino ${ }^{2,4,55,105,115,136,153,174,196}$. O homem pode, portanto, contrair a doença de diferentes animais e igualmente transmitir-lhes a infecção 4, 74, 89, 92, 174, 295, 296.

Essa zoonose é de distribuição mundial. Sua prevalência é marcante nos países em desenvolvimento e baixa nos desenvolvidos, devido a programas de controle e erradicação, inspeção de carnes e pasteurização do

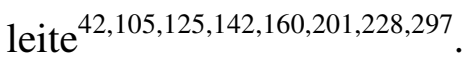

A tuberculose bovina ocasiona grandes prejuízos à economia de um país pois, vitimando o gado, cria dificuldades para a melhoria do padrão de vida de vastos núcleos humanos que se ocupam da exploração pecuária e, diminuindo o rendimento de carne e leite dos rebanhos, acarreta para a população o decréscimo do consumo de dois produtos básicos da alimentação. Além disso, representa uma ameaça para a saúde humana que dependerá, em primeiro lugar, da existência da doença no bovino e, posteriormente, dos hábitos alimentares da população, principalmente a ingestão 
de leite cru ou não fervido, e o contágio por inalação ou contato com o $\operatorname{gado}^{54,56,74,110,156,201,217,237,273}$.

No Brasil, a situação da tuberculose bovina não é bem conhecida, pois não existe um levantamento confiável que permita estimar a prevalência da doença e nem trabalhos científicos que nos forneçam objetivamente a freqüência do M.bovis em tuberculose humana ${ }^{4,201}$.

Nos outros países tropicais, também existe uma notável falta de informações a respeito da extensão e distribuição da tuberculose humana devida ao M.bovis, mas relatos disponíveis até o ano de 1996 sugeriram que em 94 (69\%) dos 136 países tropicais, existiam significantes níveis de tuberculose nos bovinos. Se correta, esta informação terá sérias implicações em saúde pública à luz da atual epidemia HIV/AIDS ${ }^{89,129,196,228 .}$

As crianças sempre foram as mais atingidas pela infecção devida ao M.bovis, por causa da maior ingestão de leite cru 49, 66, 92, 127, 148, 156, 160, 175, 196, 201, 267, 269 . A mudança na prevalência de grupos jovens para uma idade mais avançada (por reinfecção exógena ou reativação de foco antigo de M.bovis) ${ }^{4,89,127,148,161,196,201,228,295,296}$, a constante imigração de pessoas originárias de países em desenvolvimento e a persistência de doença extrapulmonar em infectados pelo HIV, trazem novos problemas para o diagnóstico e controle da tuberculose humana atribuída ao M.bovis, nos países desenvolvidos ${ }^{92,125,161,196,228 .}$

Muitas pesquisas apontam que na Europa, América do Norte, e outros países desenvolvidos, o problema da infecção causada pelo M.bovis permanece não resolvido, apesar da longa duração e relativamente bem sucedidos esforços de combate da tuberculose bovina, através da pasteurização do leite (aquecimento do leite à uma temperatura e durante o período de tempo que sejam necessários para destruir todos os agentes patogênicos que possa conter, sem causar mais que modificações de mínima importância na sua composição, sabor e valor nutritivo) ${ }^{158}$, e abate do gado tuberculina-positivo (reatores ao PPD) $56,92,125,142,163$.

Em muitos países, a reinfecção de rebanhos de bovinos tem ocorrido através 
de contatos com o homem, gado importado e reservatórios silvestres ${ }^{56,228}$. O homem tornou-se um importante reservatório de M.bovis proveniente do bovino, e essa transmissão tem sido registrada na Inglaterra, França, Estados Unidos, Holanda, Suíça, Suécia, Dinamarca, Nova Zelândia, Alemanha, Canadá, Austrália, Rússia, Turquia, Checoslováquia e outros países 4, 66, 81, 92, 105, 148, 160, 163, 175, 228 . Entretanto, em países desenvolvidos como a Grã-Bretanha, Irlanda e Nova Zelândia, os animais silvestres adquiriram importância significativa como reservatórios do M.bovis, podendo reintroduzir a tuberculose em rebanhos de bovinos livres de infecção $25,89,92,105,117,201,240,265$.

Em virtude da importância da infecção pelo Mycobaterium bovis em saúde pública, no ser humano e animais, a OMS convocou uma reunião sobre tuberculose zoonótica em Genebra em novembro de 1993, na qual, entre outros assuntos, foi revista a situação da tuberculose humana e animal no mundo inteiro. As discussões foram estruturadas em cinco tópicos, resultando nas seguintes conclusões e

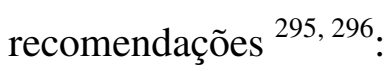

\section{- Cooperação internacional, recursos financeiros e treinamento}

Dados sobre a importância zoonótica do M.bovis, principalmente nos países em desenvolvimento, são dificultados por duas deficiências principais: a falta de informações sobre a distribuição e prevalência da infecção e doença devida ao M.bovis em animais e humanos e a falta de recursos financeiros para os países investigarem e produzirem estas informações ${ }^{295,296}$. A atual atenção focada na tuberculose humana e sua associação com HIV/AIDS deveriam atrair fundos para pesquisas do M.bovis ${ }^{129,295,296}$. É necessário coletar sólidas evidências a respeito da importância do M.bovis na atual epidemia da tuberculose humana, nos países em desenvolvimento ${ }^{295,296}$.

\section{- Epidemiologia e vigilância}

Como a tuberculose bovina tem padrões epidemiológicos diferentes nos países em desenvolvimento, é importante conduzir investigações sobre as circunstâncias nas quais o M.bovis é de importância zoonótica e seu mecanismo de 
transmissão $295,296$.

Estudos epidemiológicos bem planejados devem ser feitos para fornecer informações de qualidade, que serão a base da estratégia para programas de controle 295,296 .

\section{- Controle}

Há uma urgente necessidade de mais pesquisas sobre o desempenho de testes diagnósticos usados nos programas de controle e também para as questões de vacinação e quimioterapia $295,296$.

\section{- Diagnóstico}

Foi apontada a necessidade de testes que discriminem cepas dentro do complexo M.tuberculosis. A importância da realização de culturas confiáveis e testes diagnósticos é incontestável para investigar a epidemiologia, importância zoonótica e controle da tuberculose bovina ${ }^{295,296 .}$

Testes novos e convencionais requerem avaliação de sua performance sob condições adversas, nos países em que serão usados. Trabalhos atuais nos Trópicos enfocando este aspecto são, portanto, recomendado e esperado, visando apontar o caminho para o desenvolvimento de futuros testes ${ }^{295,296}$.

\section{- Aspectos humanos}

A efetiva colaboração entre o pessoal médico e veterinário é essencial para a investigação da importância zoonótica do M.bovis ${ }^{129,295,296 .}$

Portanto, considerando-se a importância da tuberculose no contexto da saúde pública mundial, agravada pela associação com a atual epidemia HIV/AIDS; a importância da tuberculose causada pelo Mycobacterium bovis nos países em desenvolvimento, bem como seu reaparecimento em países nos quais ela estava praticamente erradicada; a ausência de dados de prevalência e incidência da 
tuberculose causada pelo M.bovis, no Brasil e em outros países tropicais; a não utilização de métodos adequados de isolamento e identificação do bacilo; a importância dos reservatórios animais na reintrodução desta zoonose no mundo e a ênfase nas recomendações da OMS são as justificativas da presente pesquisa. 


\section{2- OBJETIVOS}

\section{1- OBJETIVO GERAL:}

$\Rightarrow$ Estudar a importância dos reservatórios animais na tuberculose humana causada pelo Mycobacterium bovis.

\section{2- OBJETIVOS ESPECÍFICOS:}

$\Rightarrow$ Estudar a etiologia, patogenia, recursos diagnósticos, mecanismos de transmissão, tratamento, prevenção e controle do Mycobacterium bovis no homem e em reservatórios animais.

$\Rightarrow$ Estudar os dados epidemiológicos disponíveis a respeito da tuberculose humana e animal causada pelo Mycobacterium bovis, no Brasil e no mundo.

$\Rightarrow$ Estudar quais são os reservatórios animais de M.bovis existentes, e os de maior importância na transmissão da tuberculose devida a este agente, aos homens e outros animais. 


\section{3- PROCEDIMENTOS METODOLÓGICOS}

Para a elaboração da Dissertação de Mestrado, foi realizada uma revisão bibliográfica de publicações nacionais e internacionais. O levantamento bibliográfico, cuja busca foi feita por assunto com o cruzamento de descritores previamente selecionados, realizou-se por meio do Serviço de Biblioteca e Documentação (SBD) da Faculdade de Saúde Pública da Universidade de São Paulo, no qual foram consultadas as seguintes bases disponíveis em rede local informatizada:

\section{a) Bases locais via terminal.}

- Base ACERVO que constitui o catálogo de livros e monografias, anais de congressos, folhetos e outros formatos de publicações, existentes na Biblioteca, a qual permite buscas e localizações dos documentos nas estantes.

- Base HIGEIA que fornece referências e resumos da produção científica e teses defendidas na Faculdade de Saúde Pública da Universidade de São Paulo.

- Banco de Dados DEDALUS que representa as coleções existentes no acervo das Bibliotecas da Universidade de São Paulo, com acesso via terminal ligado a REDEUSP. Foram pesquisados dois módulos: MONOGRAFIA, contendo referências de livros, folhetos, eventos e séries monográficas, e PUBLICAÇÕES SERIADAS que representa as coleções de revistas técnico-científicas, "abstracts", e outros.

\section{b) Bases de dados internacionais no formato de CD-ROM, em rede local informatizada:}

- MEDLINE (Medical Literature on-line) que reúne referências e resumos de artigos de cerca de 3.300 periódicos de âmbito internacional no campo das ciências da saúde e afins.

- LILACS (Literatura Latino-Americana em Ciências da Saúde) que reúne referências e resumos de documentos da literatura em ciências da saúde gerada na 
América Latina, a partir de 1980.

\section{c) Outras fontes:}

Artigos e capítulos de livros importantes para o estudo do assunto abordado foram consultados em acervos individuais de pesquisadores docentes da Universidade de São Paulo, e de outras Instituições de Ensino e Pesquisa, nacionais e internacionais.

De posse de toda a bibliografia disponível, foi efetuada uma análise, por meio de leitura, com a finalidade de avaliar os artigos pertinentes ao objetivo proposto.

Enumerados pela ordem de aquisição, os artigos assim selecionados foram catalogados em fichas individuais, seguindo uma ordem alfabética de autores, nas quais constaram resumos dos assuntos a serem abordados na Dissertação.

Em sequiência, foi analisada a ordem de prioridade dos mesmos, segundo os tópicos mais relevantes. 


\section{4- HISTÓRICO}

A tuberculose bovina originou-se na Inglaterra e Europa Continental e, provavelmente, nenhum assunto pertencente à bacteriologia e doenças infecciosas, gerou debates mais calorosos entre os primeiros cientistas médicos do que o papel da tuberculose bovina na doença humana ${ }^{92,220}$.

O risco da infecção tuberculosa pela ingestão de carne tem sido objeto de interesse e controvérsia, desde os tempos bíblicos, e há regras contra o consumo de carne tuberculosa no Talmud, codificado em fins do século II, no qual os rabinos proibiam ao povo hebreu o uso de carne de bovinos, em cujos pulmões houvesse lesões ulcerosas. Em 1307, lei semelhante foi promulgada em Munich, Alemanha; e em 1788, em Leipzig, a morte de 12 estudantes foi atribuída à ingestão de carne de animal tuberculoso ${ }^{110}$.

Carmichael, em 1810, em Londres publicou um ensaio sobre a natureza da escrófula (linfadenite cervical tuberculosa), no qual expõe a sua convicção de que o leite de vaca era freqüentemente responsável pela doença ${ }^{110}$. Entretanto, a ligação entre a escrófula e ingestão de leite de vacas doentes, somente foi estabelecida por Klencke em 1846, que reproduziu a doença em coelhos mediante injeção intravenosa de leite bovino procedente de vacas tuberculosas 8 , 57, 68, 92, 125, 228 . Klencke relatou também a história clínica de 16 crianças alimentadas com leite de vacas tuberculosas e que adoeceram de tuberculose intestinal, ganglionar, cutânea e óssea, concluindo que a escrófula humana e a doença encontrada nos animais eram idênticas ${ }^{110}$.

Em 1866, Villemin, um cirurgião militar Francês, demonstrou o caráter transmissível da tuberculose humana e bovina pela inoculação de material tuberculoso de humanos e de vacas doentes em coelhos, ao constatar que estes desenvolveram tuberculose, e também, acidentalmente, observou que material infectado de gado era mais virulento para o coelho do que o material análogo proveniente de humanos ${ }^{34,68,125,137,225,297}$. Villemin afirmou que "a tuberculose é uma doença infecciosa produzida por uns "fermentos" que se encontram obrigatoriamente nas lesões dos tísicos", e chegou às seguintes conclusões: 
- "A tuberculose é uma enfermidade específica";

- "É produzida por um agente ("fermento") inoculável;"

- "Pode transmitir-se do homem ou do bovino aos animais susceptíveis, como coelho, cobaio, cabrito e, de animais enfermos aos outros susceptíveis à enfermidade";

- "É uma das enfermidades mais destrutivas" 8.

Em 1868, Chaveau transmitiu a doença experimentalmente para bezerros $^{92,125}$.

O patólogo alemão Paul von Baumgarten, foi o primeiro que visualizou (microscopicamente) bacilos tuberculosos nas preparações de tecidos humanos com lesões específicas. Além disso, Baumgarten comunicou que havia conseguido cultivar estes bacilos na câmara anterior do olho dos coelhos inoculados por via oftálmica. Este importante trabalho foi publicado em $1882^{8}$.

Estes e outros relatos, especialmente os dos veterinários sobre a mastite tuberculosa das vacas, provavelmente impressionaram Koch ${ }^{110}$. O renomado Robert Koch e seus pontos de vista eram o centro das controvérsias durante o início de 1900. Nesta época o Dr. Koch havia ganho reputação mundial como resultado de seu trabalho sobre o Bacillus anthracis como causa de doença (1877) e sua descoberta do “Tuberkelbacillen” (bacilo da tuberculose), por meio de cultivo, em 24 de março de 1882, apontando o escarro do doente tuberculoso como a principal origem do material infectante $68,92,110,111,125,137,220,237,297$.

Antes de Villemin demonstrar a natureza infecciosa da tuberculose e da descoberta de seu agente específico por Koch, acreditava-se que a tuberculose nos seres humanos era uma doença hereditária, devido à freqüência com a qual sucessivas crianças de pais tuberculosos sucumbiam à doença ${ }^{137}$. Nesta data, Koch apresentou na Sociedade de Fisiologia de Berlim seu histórico trabalho denominado "A etiologia da tuberculose", onde comunicou que havia utilizado, pela primeira vez, o bacilo que produzia a tuberculose, e que havia conseguido reproduzir a doença 
mediante inoculação de cultivos puros do germe isolado, nos animais de laboratório ${ }^{8}$.

Koch inicia sua extraordinária publicação com as seguintes frases: "O descobrimento feito por Villemin de que a tuberculose é contagiosa para os animais, foi reconhecido por alguns, mas não por outros, resultando em dúvidas a esse respeito. Porém, desde então, Cohnhein, Salomonsen e von Baumgartem com suas inoculações na câmara anterior do olho dos coelhos, como também Tappeimer e outros, com seus ensaios de inalação, comprovaram, sem dúvida, a contagiosidade da tuberculose, que no futuro deverá ocupar seu lugar correspondente entre as enfermidades infecciosas" ${ }^{8,110}$. Um pouco mais adiante se lê: "mais 10 casos de tuberculose bovina, com tubérculos calcificados nos pulmões, às vezes também no peritôneo e, em um caso no pericárdio. Em todos os casos foram encontrados bacilos, preferencialmente no interior das células gigantes situadas no tecido ao redor da massa calcificada"... E, finalmente disse: "Uma outra fonte de infecção pela tuberculose, constitui indubitavelmente, a tuberculose dos animais domésticos, e em primeiro lugar a tuberculose bovina. Com isto, fica também indicada a posição que a saúde pública terá de assumir, no futuro, em relação ao problema do perigo da carne e do leite de animais tuberculosos. A tuberculose bovina é idêntica à tuberculose do homem e, portanto, uma doença transmissível à este. Ela deve, por isso, ser tratada como as outras doenças infecciosas transmissíveis do animal para o homem. Possa o perigo que resulta do uso da carne ou do leite de animais tuberculosos ser grande ou pequeno, ele existe e deve, portanto, ser evitado. É bastante conhecido que a carne infectada com antraz é consumida por muitas pessoas e, freqüentemente, durante muito tempo, sem qualquer prejuízo e, não obstante, ninguém concluirá que o comércio dessa carne deva ser permitido. Com relação ao leite das vacas tuberculosas, é digno de nota que, a propagação do processo tuberculoso à glândula mamaria é, não raramente, observada pelos veterinários e é, por isto, bem possível que, nestes casos, o bacilo da tuberculose possa misturar-se diretamente com o leite" $, 8,110$.

A visão de Koch foi geralmente aceita por médicos e veterinários ${ }^{125,220}$. Os veterinários estavam prontos para defenderem medidas de prevenção em relação à transmissão da tuberculose através do leite e carne de gado infectado ${ }^{220}$. 
Como Koch não havia dado um nome específico para o bacilo, que era conhecido como bacilo de Koch, em 1883 Zopf propôs o titulo "Bacterium tuberculosis" e, em 1886 Lehmann e Neumann atribuiram a espécie ao gênero "Mycobacterium", 68, 170, 220, 223.

Durante a reunião da Associação de Veterinários dos Estados Unidos, na Filadélfia, em 1887, várias resoluções solicitavam uma legislação que instituísse a inspeção veterinária de fazendas leiteiras e abatedouros para eliminar a venda de leite e carne de gado tuberculoso. Muitas associações de classes atenderam a solicitação. Proeminentes veterinários impulsionaram a fervura do leite como uma medida preventiva contra a transmissão da doença ao consumidor ${ }^{220}$.

Em 1890, Dr. Koch engajou-se em extensas pesquisas a respeito de vários aspectos da doença. Uma das questões colocadas por muitos investigadores foi a do perigo da tuberculose bovina para a saúde humana ${ }^{220}$.

O perigo da transmissão da tuberculose de bovinos infectados para o homem foi reconhecido em 1896 e 1898 por Theobald Smith, pesquisador americano, que demonstrou que o bacilo da tuberculose encontrado no gado era diferente do encontrado no homem, ao utilizar pela primeira vez uma classificação ou tipificação dos bacilos tuberculosos baseada na diferença da patogenicidade das variedades bovina e humana para o coelho $2,8,92,102,110,111,127,266$. Ao mesmo tempo demonstrou que as cepas bovinas cresciam mais lentamente que as humanas em caldo glicerinado e reduziam a acidez do meio, fenômeno conhecido como "Curva de Theobald Smith"

Smith declarou na época (1898) que: "se o bacilo bovino pode invadir o corpo humano sem permissão ou obstáculo, não temos que nos proteger apenas contra a infecção alimentar através do leite e produtos lácteos, mas também da doença por inalação, a qual o homem está exposto nos estábulos que contenham gado tuberculoso" 266 .

Koch conduziu experimentos que pretendiam esclarecer a questão da intertransmissibilidade. No entanto, criou um tumulto entre aqueles que assistiam ao 
Congresso Internacional de Tuberculose, ocorrido em Londres, em julho de 1901, quando ele reverteu a sua posição em relação a patogenicidade do bacilo da tuberculose bovina (Mycobacterium bovis) para humanos ${ }^{110,127,220,266 .}$

A base para esta mudança foi a sua tentativa de infectar um grupo de 19 bovinos com culturas e tecidos infectados de humanos que tinham tuberculose. Exames post mortem do gado, 6 a 8 meses após, não apresentaram lesões, exceto no local da inoculação. O pequeno foco supurativo que foi observado era, de acordo com Koch, exatamente igual àqueles resultantes da injeção de bacilos tuberculosos mortos, levando-o à convicção de que a tuberculose humana diferia da bovina e não poderia ser transmitida ao gado, e de que o inverso era verdadeiro ${ }^{110,220}$.

Além de bovinos, realizou experimentos com ovelhas, porcos e vitelos, por acreditar que a inoculação de culturas puras nos animais, permitiria decidir se a tuberculose humana resultava de contágio inter-humano ou se era de origem animal. Mas, até aquele momento, Koch não havia encontrado no homem uma amostra bacilar com os caracteres do bacilo do tipo bovino, nem mesmo em casos de tuberculose dos órgãos digestivos, nos quais uma infecção causada pelo uso de manteiga ou leite de animal doente era previsível ${ }^{110}$.

Por isso, dirigindo-se ao Congresso, declarou:

"É impossível dar a esta questão uma resposta direta porque, naturalmente, a investigação experimental com seres humanos está fora de cogitação. Indiretamente, porém, podemos avaliá-la. É bem sabido que o leite e a manteiga consumidos nas grandes cidades contêm, muito freqüentemente, grandes quantidades de bacilos viáveis de tuberculose bovina, como o provam as numerosas inoculações experimentais destes produtos. A maioria dos habitantes das cidades ingere, diariamente, estes bacilos viáveis e perfeitamente virulentos da tuberculose bovina e, involuntariamente, realizam a experiência que não temos o direito de praticar. Se os bacilos da tuberculose bovina fossem capazes de infectar seres humanos, numerosos casos de tuberculose causada pela ingestão de alimentos contendo os bacilos da tuberculose deveriam ocorrer entre os habitantes das grandes cidades, especialmente entre as crianças". E acrescenta: "Eu avaliaria a importância da infecção pelo leite e 
carne de gado tuberculoso, e pela manteiga preparada com seu leite, como ligeiramente maior do que a da transmissão hereditária e, portanto, não julgo aconselhável adotar qualquer medida contra ela“ 110, 220 . Concluindo, disse: "O homem é imune à infecção pelo bacilo bovino, ou é tão pouco susceptível, que não é necessário tomar medidas especiais para anular o risco de infecção" 68, 89, 110, 118, 125, 127, 137, 154 . Entretanto, salientou a necessidade de pesquisas mais amplas com culturas puras de diferentes casos de tuberculose humana, para que se pudesse estabelecer a freqüência do tipo bovino do bacilo no homem ${ }^{110}$.

Estas declarações provocaram uma tempestade de desafios e protestos de proeminentes pesquisadores no campo das doenças infecciosas ${ }^{110,127,137,220}$.

Em conseqüência, o Rei Eduardo VII mandou instalar uma Comissão Real de Tuberculose para questionar e responder:

1- Se a doença tuberculose em animais e homens é uma e a mesma.

2- Se animais e homens podem ser reciprocamente infectados por ela.

3- Sob que condições, se houverem, ocorre a transmissão da doença de animais ao homem, e quais as circunstâncias favoráveis e desfavoráveis para essa transmissão ${ }^{220}$.

Enquanto Koch estava correto na sua visão de que o gado tinha considerável resistência à exposição ao tipo humano do bacilo da tuberculose, o qual ele usou nos seus primeiros experimentos, ele estava completamente errado em relação à importância do tipo bovino como causa da tuberculose em seres humanos ${ }^{220}$.

Os críticos de Koch apontaram que seus experimentos eram muito limitados em abrangência, por não incluírem inóculos de uma variedade de fontes humanas, e por haver utilizado em seus estudos, culturas avirulentas da Escola de Veterinária de Berlim 110, 220 . Outros pesquisadores, daquele mesmo período, reportaram vários exemplos de transmissão bem sucedida da tuberculose para o gado, usando material de lesão de origem humana, especialmente de crianças ${ }^{220}$.

Em 1902, Mc Fadyean declarou que tubérculos bovinos de vacas leiteiras 
foram a causa principal de tuberculose intestinal em crianças, na Escócia, mas foi Ravenel (1902) que obteve a primeira prova definitiva da transmissão da tuberculose bovina ao homem, por ingestão, ao isolar em cultura pura os bacilos dos gânglios mesentéricos de uma criança que havia morrido de meningite tuberculosa no Hospital Infantil da Filadélfia, inoculando-os em dois vitelos e em uma vaca, na veia jugular e na cavidade peritonial. Os animais morreram em menos de um mês, e a autópsia não deixou dúvidas de que a causa da morte havia sido a tuberculose ${ }^{92,110,228}$.

Em 1903, Behring expôs a sua célebre tese de que a tuberculose do adulto representava a exacerbação de uma primo-infecção adquirida na infância, e que o leite, do qual se nutria o lactante, era a fonte principal dos bacilos ${ }^{110}$.

Os seus estudos se apoiaram na "inesperada" comprovação, feita por seu colaborador Römer, de que os corpos proteicos atravessavam inalterados a mucosa intestinal dos animais de laboratório recém-nascidos, como se fossem introduzidos diretamente no sangue, ao passo que, nos animais adultos, estas substâncias deviam ser transformadas em peptona antes de poderem transpor a mucosa intestinal. Verificou que a mesma diferença, entre crianças recém-nascidas e adultos, se observava em relação às proteínas antitóxicas dos soros antitetânicos e antidiftéricos. Considerou então, inteiramente plausível que o mesmo fato ocorresse com as bactérias, e pôde confirmar esta suposição ao ministrar, em cobaios, Bacillus anthracis misturados com leite. Os animais adultos excretavam prontamente os bacilos e não adoeciam. Ao contrário, cobaios submetidos à experiência, até 8 dias depois de nascidos, morriam rapidamente. Investigação semelhante com o bacilo da tuberculose proporcionou resultados idênticos ${ }^{110}$.

Em 1904 a Comissão Real Britânica, relatou:

"Tubérculos de origem bovina, podem crescer no homem provocando uma tuberculose idêntica à usual tuberculose humana" 92, 220 .

O $2^{\circ}$ Congresso aconteceu em Paris em 1905, no qual veterinários declararam a transmissão da tuberculose humana aos animais ${ }^{220}$.

Em 1907, a Comissão Real em Tuberculose fez uma declaração categórica 
sobre o assunto: "O leite da vaca que contenha o bacilo da tuberculose bovina é evidentemente uma causa de tuberculose, inclusive fatal, no homem. Nossos resultados nitidamente apontam a necessidade de medidas mais severas do que as que vêm sendo aplicadas atualmente, para impedir a venda ou o consumo de tal leite" ${ }^{, 110,220}$.

Assim, quando o Congresso Internacional de Tuberculose se reuniu em 1908, em Washington, o tópico de maior interesse continuava sendo o das relações entre a tuberculose bovina e humana, principalmente porque, presente à reunião, Koch ia expor seu pensamento sobre o assunto pela primeira vez desde 1901. Mas, quando se esperava que modificasse seu ponto de vista, Koch confirmou a sua já conhecida convicção de que não se devia dar grande importância à tuberculose bovina na luta contra a doença no homem. Os bacilos do tipo bovino podiam ser encontrados nos seres humanos, mas com raras exceções, eram de virulência atenuada e permaneciam localizados. Para Koch, os poucos casos conhecidos de tuberculose humana fatal, atribuídos ao tipo bovino, não resistiriam à uma crítica. Além do mais, nenhum caso de tuberculose pulmonar humana de origem bovina, havia sido inequivocamente demonstrado ${ }^{110,220}$.

Como no congresso anterior, também desta vez, Koch não pôde silenciar os opositores, agora apoiados nos resultados parciais das investigações da Comissão Real. E ao encerrar-se o Congresso de Washington em 3 de outubro, foi aprovada a seguinte resolução: "Os maiores esforços devem continuar sendo desenvolvidos na luta contra a tuberculose, para impedir a transmissão do homem para o homem da infecção tuberculosa, como a fonte mais importante da doença. Além do mais, devem continuar as medidas preventivas contra a tuberculose bovina, e a possibilidade de sua propagação ao homem deve ser reconhecida" ${ }^{110}$.

Os relatórios da Comissão Real publicados em 1907, 1909 e 1911, são volumosos e contém dados sobre todos os aspectos da tuberculose em animais. Uma importante descoberta foi a clara definição de três tipos distintos de bacilos e que o tipo humano (Mycobacterium tuberculosis) era responsável pela maioria dos casos da doença em humanos, o tipo bovino (Mycobacterium bovis) no gado, e o tipo aviário 
(Mycobacterium avium) nas aves, além de outras micobactérias saprófitas. Contudo, o tipo bovino também era encontrado em humanos ${ }^{68,220}$.

Após 10 anos de existência (1901-1911), a Comissão Real finalmente concluiu que vacas tuberculosas representavam um sério risco à saúde humana. Eles demonstraram que o leite da vaca doente, contendo o bacilo da tuberculose bovina era o principal vetor da transmissão, porque causou tuberculose não pulmonar em pessoas, especialmente em crianças, e que a infecção pulmonar humana poderia ser adquirida de gado infectado, por inalação ${ }^{68,92,110,127,220}$. Foi demonstrado também que o bacilo bovino, além de infectar crianças, foi capaz de produzir as mais severas formas de tuberculose: meningite e tuberculose miliar. Entretanto, por muito tempo, apenas o risco de infecção alimentar através do leite foi considerado ${ }^{266}$.

Eles ainda investigaram o uso do teste tuberculínico em animais, para fornecer a freqüência da infecção, e determinaram que todas as vacas de fazendas leiteiras deveriam ser submetidas ao teste e que o leite e a nata seriam pasteurizados; medidas que se tornaram universalmente aceitas. Foram também instituídas leis governamentais, implantando a inspeção da carne e disposição das carcaças tuberculosas $68,92,127,220$.

Apesar de a Comissão Real ter se referido à cepa bovina como M.bovis em 1911 , esse nome não foi reconhecido até $1970{ }^{228}$. Durante esse período o bacilo da tuberculose bovina era considerado uma espécie ou variante do Mycobacterium tuberculosis, e era denominado M.tuberculosis subsp.bovis ou M.tuberculosis var.bovis. A separação da espécie nomeada Mycobacterium bovis foi proposta por Karlson e Lessel, em $1970^{32,125 .}$ 


\section{5- EPIDEMIOLOGIA DA TUBERCULOSE CAUSADA PELO}

\section{Mycobacterium bovis.}

\section{1- DADOS EPIDEMIOLÓGICOS}

\subsection{1- OCORRÊNCIA NO BOVINO}

\subsubsection{1- No mundo}

Os principais indicadores da existência de tuberculose no bovino são a presença de animais tuberculina-positivos e de lesões comprovadamente tuberculosas $^{74,237}$. As rotas mais comuns da infecção no gado são a respiratória e a digestiva. As formas de transmissão cutânea, transplacentária e genital, são menos comuns $^{228}$.

De 420 milhões de cabeças de gado que existiam nas Américas (América do Norte, América Latina e Caribe), na década de 90, pouco mais da metade criavam-se em países ou zonas consideradas infectadas por tuberculose bovina (prevalência de $1 \%$ ou mais da população bovina total) ou onde não havia informação disponível sobre sua prevalência. Estimou-se que na América do Sul, possivelmente estivessem infectados 4 milhões de animais, o que representaria perdas econômicas consideráveis devidas à doença nas vacas leiteiras e no gado de corte, e conseqüente redução na produção de carne, leite e derivados lácteos, constituindo um sério fator limitante para o desenvolvimento da indústria de criação de gado, incluindo o mercado internacional de animais e de produtos de origem animal, e uma ameaça para a saúde humana 54, 56, 74, 201, 217, 237, 273 . Estimou-se que os animais infectados perdiam de 10 a $25 \%$ de sua capacidade produtiva ${ }^{201}$.

De aproximadamente 300 milhões de animais que constituíam a população bovina na América Latina e Caribe, nesta época apenas 80 milhões encontravam-se em países nos quais as taxas de infecção por M.bovis eram baixas ou nulas ${ }^{156,216}$. Os remanescentes 220 milhões encontravam-se em países com moderada ou alta prevalência, ou onde informações recentes não eram disponíveis. Dos países da América Latina, apenas Cuba e Venezuela tinham programas nacionais de controle. 
As maiores taxas de infecção ocorriam nas regiões produtoras de leite, localizadas nos arredores das grandes cidades na América do Sul ${ }^{156,216 .}$

Na década de 30, cerca de 40\% dos bovinos abatidos na Inglaterra e País de Gales apresentavam lesões tuberculosas na inspeção post mortem e, em 1949, 35\% das vacas leiteiras estavam infectadas, enquanto nos Estados Unidos a prevalência era de $3,3 \% 68,110,125,148,156,228$. Nessa época, havia muita resistência aos programas de controle na Grã-Bretanha, devido à alta prevalência da doença nos rebanhos bovinos. As autoridades consideraram impraticável o abate de todo o gado sensível à tuberculina, porque seria necessário sacrificar um terço ou a metade de todo o gado leiteiro do país, e também uma proporção considerável do rebanho mais jovem. As conseqüências seriam o pagamento de somas enormes para a indenização aos criadores e a redução imediata do suprimento de leite, aumentando o preço já elevado. Além do mais, entre os médicos, havia o conceito da menor virulência do bacilo para o homem, e a crença de que a ingestão de leite contendo bacilos da tuberculose teria efeito favorável na população humana, imunizando-a contra a doença $^{110}$.

Em 1932, foi publicado o relatório de uma comissão designada para estudar o problema da tuberculose bovina na Inglaterra, que forneceu os seguintes elementos: pelo menos $40 \%$ dos bovinos estavam infectados, mas apenas a minoria era infectante; aproximadamente $0,2 \%$ de todas as vacas sofriam de tuberculose no úbere e, portanto, eliminava bacilos viáveis no leite; cerca de $40 \%$ das vacas abatidas nos matadouros públicos, apresentavam lesões macroscópicas e cerca de 6,7\% do leite cru no mercado, continha bacilos viáveis ${ }^{110}$.

Em 1950, 18\% dos rebanhos tinham pelo menos um animal infectado, mas em 1961 este quadro foi reduzido para 3,5\%, em 1965 para 1,0\% e para $0,15 \%$ em 1990 68, 125, 148, 156, 228 . Em 1993, com exceção do sudoeste da Inglaterra, cerca de $0,06 \%$ dos rebanhos possuíam animais reatores à tuberculina no Reino Unido. A alta incidência no sudoeste da Inglaterra estava relacionada com a infecção em texugos (animais que constituem o principal reservatório da infecção por M.bovis, nessa região) ${ }^{57,209}$. 
Na França, em 1948, 40\% dos rebanhos de gado reagiam à tuberculina e 2 a $4 \%$ das vacas apresentavam mamite tuberculosa ${ }^{110}$. No período de 1983 a 1992, de um total de 610 isolamentos de micobactérias em bovinos, $446(73,1 \%)$ cepas eram de M.bovis $^{264}$.

No período de 1947 a 1948, na Alemanha, a prevalência da infecção por M.bovis nos bovinos era de 30 a $35 \%$ para o gado de corte e de 50 a $60 \%$ para o gado leiteiro. Nessa época, a situação do leite pasteurizado era pouco satisfatória, pois a proporção de leite contendo bacilos era de 4,8\% em 1948, aumentando para $10 \%$ no ano seguinte, e mantendo-se entre 6,6 e 7,6\% no princípio de 1950; revelando uma baixa eficiência no controle do método de pasteurização e um risco para a população humana ${ }^{110}$.

Na Nova Zelândia, em 1994 existiam 47.000 rebanhos, com 8,36 milhões de cabeças de gado, dos quais, $45 \%$ era gado leiteiro e 55\%, gado de corte ${ }^{269}$. Em 1958, havia aproximadamente, 10,7\% de animais reatores à tuberculina. Em 1962, 28,5\% do gado do sul da ilha era tuberculina-positivo e acima de 20,0\% dos animais abatidos tinham lesões tuberculosas. Em 1970, apesar das medidas de controle, o quadro ainda era de $27,7 \%$ e $17,8 \%$, respectivamente ${ }^{65,68}$. Em 1986, apenas cerca de $2 \%$ do total nacional de rebanhos bovinos, estava infectado por M.bovis ${ }^{65}$.

Em 1992, ocorreu um surto epidêmico de tuberculose bovina em 2 rebanhos de gado de 2 fazendas do sudoeste da Escócia. O primeiro animal doente foi um bezerro de 5 meses de idade, e por isso, todos os outros 185 animais do rebanho foram testados com tuberculina, obtendo-se 11 (5,9\%) animais reatores. Foi aplicada restrição de movimentos aos não reatores e repetição do teste a cada 60 dias, até que 2 testes negativos consecutivos fossem obtidos. Os 11 animais reatores foram mortos e submetidos ao exame post mortem. Sete $(63,6 \%)$ animais apresentaram lesões tuberculosas visíveis, e o M.bovis foi isolado em 6 animais ${ }^{57}$.

Dos 261 animais pertencentes ao segundo rebanho, 84 (32,2\%) foram reatores à tuberculina e 5 apresentaram reação inconclusiva. Todos os animais deste rebanho também foram abatidos e submetidos ao exame post mortem. Entre os 84 animais reatores, $34(40,5 \%)$ apresentaram visíveis lesões tuberculosas e entre os 172 não 
reatores, $13(7,6 \%)$ tinham lesões. A identificação do bacilo não foi realizada ${ }^{57}$.

No período de 1945 a 1948, na Irlanda do Norte, 33\% das vacas leiteiras estavam tuberculosas, e de 1983 a 1994, na região sudoeste da Irlanda, a prevalência da infecção por M.bovis no gado diminuiu gradualmente, de 467 animais tuberculinapositivos por 100.000 cabeças de gado em 1983 , para 158 por 100.000 em $1994^{85,231}$.

A suposta erradicação da tuberculose por M.bovis em bovinos, na Hungria, foi concluída em 1980; mas um estudo realizado no período de 1988 a 1993, demostrou que, de acordo com a região, ainda havia 5-15\% de rebanhos de gado tuberculina-positivos. Além disso, de 1.848 amostras de órgãos de bovinos, provenientes de 25 regiões que ainda apresentavam surtos epidêmicos, foram isoladas $191(10,3 \%)$ cepas de M.bovis ${ }^{162}$.

Na Espanha, em 1994, 5,7\% dos rebanhos de bovinos estavam infectados por M.bovis. O programa de erradicação iniciado em 1965 diminuiu a prevalência da doença, mas, em anos recentes, não houve uma redução significativa ${ }^{17}$.

Em junho de 1989, foi detectado o primeiro surto de tuberculose bovina na Pennsylvania, Estados Unidos, desde 1978. Em um rebanho de 122 vacas leiteiras, 109 (89\%) eram tuberculina-positivas, e dessas, 16 (15\%) apresentaram lesões tuberculosas. Não foi identificada a fonte de infecção desse surto ${ }^{42}$. No período de 1982 a 1991, foram detectados 83 rebanhos de gado infectados por M.bovis em 23 Estados americanos. A média anual foi de 8,5 rebanhos infectados ${ }^{106}$.

Um estudo mais amplo demonstrou que nos Estados Unidos, no período de 1950 a 1990, houve uma queda na incidência de bovinos infectados pelo M.bovis de 4,9\% para 0,08\%, enquanto no México em 1989, a doença foi diagnosticada em $11,3 \%$ das vacas e em $0,5 \%$ do gado de corte, cuja carne era destinada ao consumo ${ }^{92}$. A compra de gado infectado do México manteve a infecção por M.bovis nos Estados Unidos 92, 106. De 1982 a 1991, o número de bovinos importados do México aumentou de 329.000 para cerca de 1,2 milhões. Durante o mesmo período, os bovinos mexicanos foram responsabilizados por 55 a $77 \%$ de todos os casos de tuberculose bovina confirmados nos rebanhos americanos ${ }^{92}$. Em 1994, estimou-se 
que a prevalência da tuberculose em rebanhos bovinos nos Estados Unidos, era de $0,003 \%{ }^{106}$.

Durante o período de 1982 a 1991, no Canadá, apenas 36 rebanhos de gado foram infectados por M.bovis, com uma média inferior a 4 rebanhos por ano ${ }^{106}$.

No período de 1994 a 1996, dos 56 países africanos, 44 reconheceram oficialmente a presença da tuberculose bovina em sua população animal e apenas 30 aplicavam alguma medida de controle. Da população total de gado leiteiro e de corte na África, mais de 50\% encontrava-se em países nos quais não existiam quaisquer medidas de controle para tuberculose bovina, e cerca de $90 \%$ da população humana na África vivia nestes países, sendo expostas diretamente ao gado ou a seus $\operatorname{produtos}^{130,274}$.

Entretanto, em 1992, realizou-se um estudo, pelo período de 6 meses, no distrito de Malopo, na África do Sul, que demonstrou uma prevalência de M.bovis de $0,06 \%$ no gado, sendo considerada muito baixa. Muitos fatores poderiam ter contribuído para este fato, incluindo boas condições de pastagens em extensos campos, reduzindo a contaminação do pasto; pouco ou nenhum contato entre animais selvagens e a população de gado local, e a mínima importação de gado ${ }^{20}$.

No Paraguai, a prevalência da infecção por M.bovis, por rebanho de gado, nas bacias leiteiras de Asunción, Alto Paraná e Encarnación, era em 1975-76, de $57 \%, 29 \%$ e $44 \%$, respectivamente ${ }^{55}$. No período de 1981 a 1990, no país como um todo, a porcentagem de rebanhos infectados diminuiu de $9,8 \%$ para $1,3 \%{ }^{156}$.

Na Argentina, em 1942, a freqüência da tuberculose nas vacas leiteiras, variava de 25 a 70\%. Em 1981, cerca de 4,5\% do gado ainda estava infectado com M.bovis ${ }^{85,92}$. Em 1989, a prevalência média de infecção tuberculosa no gado foi estimada em 4\%, mas variações importantes foram observadas de acordo com a região, a idade e o tipo de gado, sendo que um ou mais reatores foram detectados em $37 \%$ dos rebanhos ${ }^{156}$.

Em 1994, a Argentina e Brasil, com uma população bovina de 51 milhões e 137 milhões, respectivamente, deveriam abrigar juntos, 3,5 milhões de gado 
infectado por M.bovis ${ }^{156,216}$. Na Argentina, a perda na produção de leite de vacas tuberculosas girou em torno de $18 \%$, como resultado de um atraso na primeira lactação e da diminuição no número e duração das lactações, quando comparadas aos animais sadios; demonstrando assim, que os efeitos da doença na economia e saúde animal progridem lenta e uniformemente ${ }^{156}$.

Como se pode observar a taxa de infecção no gado, provavelmente o melhor indicador para a presença da doença humana, varia de país para país. Apesar dos dados não serem recentes, em 1970, países como a Venezuela, Brasil, Colômbia, Equador e Bolívia tinham baixas taxas de reatores à tuberculina. Em contraste, no Peru, Argentina e Chile, as taxas eram altas. No Peru, a causa era a grande importação de gado leiteiro da Europa ${ }^{92}$.

O vírus da imunodeficiência bovina (BIV) está intimamente relacionado ao vírus da imunodeficiência humana (HIV), e acredita-se que o BIV tenha uma distribuição mundial. O papel, se algum, da infecção pelo BIV na epidemiologia da infecção do M.bovis no bovino, é desconhecido ${ }^{216}$.

Em 1995, amostras de soro de 928 vacas adultas de 256 rebanhos em Ontario, Canadá, foram testadas para anticorpos BIV. Concluiu-se, que apesar da baixa prevalência da infecção por BIV entre o gado leiteiro em Ontario, ela não é incomum, e que um resultado positivo ao teste BIV estava associado com uma diminuição na média da produção de leite ${ }^{216}$.

\subsubsection{2- No Brasil}

Considerando a importância que a pecuária assume na economia nacional, os dados referentes à freqüência da tuberculose bovina nos rebanhos brasileiros sempre foram insuficientes, não permitindo uma visão exata sobre a verdadeira extensão do problema $4,110,201$.

Feldman (1955) ${ }^{110}$ já apontava as razões para esta falta de informação, dizendo que a maioria dos dados procedia de matadouros e frigoríficos, onde a 
anotação de alterações encontradas nos animais abatidos era atribuição rotineira do serviço de inspeção de carnes. Entretanto, estes dados não serviam para uma avaliação do verdadeiro grau de difusão da tuberculose no bovino, especialmente do ponto de vista da saúde pública. Em primeiro lugar, porque o gado de corte, além de ser criado em pastagens, geralmente, extensas, nas quais a possibilidade da propagação da doença é reduzida, era abatido antes de atingir a idade em que a porcentagem da infecção tuberculosa se elevava de modo considerável. Em segundo lugar, a transmissão da tuberculose bovina ao homem pela ingestão de carne era de importância quase nula, porque além de ser objeto de inspeção obrigatória nos matadouros e frigoríficos, era submetida à cocção antes de ser consumida ${ }^{110}$.

E sugeriu que, informes idôneos a respeito da prevalência da infecção tuberculosa nos bovinos, e dos riscos de contágio para a população, seriam obtidos pelo inquérito tuberculínico no gado leiteiro, porque este alcançava a idade em que a doença adquire maior grau de disseminação; era freqüentemente mantido em regime de estabulação ou semi-estabulação, que favorecia o contágio de um animal para outro e deste para o homem (inalação, contato); e produzia o leite, que era um dos meios de transmissão da doença para o homem ${ }^{110}$.

Nos poucos dados disponíveis, constatou-se que, em 1929 no Brasil, cerca de 50\% dos bovinos de Niterói, no Estado do Rio de Janeiro, estavam infectados pelo M.bovis. Neste mesmo ano, no Estado do Rio Grande do Sul, 20\% dos bovinos estavam infectados. Estudos posteriores indicaram que, no período de 1937 a 1942, foram tuberculinizados 27.887 bovinos no Rio Grande do Sul, dos quais 9,4\% era tuberculina-positivos, sendo que, em 1944 o número de animais reatores baixou para $7,7 \%$, e em 1951 , para $6,3 \%{ }^{110}$.

Em 1936, realizou-se em São Paulo a prova tuberculínica no gado de leite mantido nos arredores da cidade, encontrando-se 39,6\% de reagentes entre os animais adultos, e 10,8\% entre os bezerros testados. Devido ao elevado coeficiente de infecção tuberculosa no gado leiteiro, foram analisadas 100 amostras de leite, e $30 \%$ delas continham o bacilo de Koch. Neste mesmo ano, no Espírito Santo, encontrou-se prevalências de infecção por M.bovis nos bovinos, que oscilaram entre 
5 e $16 \%$, nas diferentes regiões do Estado ${ }^{110}$.

Em 1951, cerca de $26 \%$ do gado leiteiro de 6 municípios do Estado do Paraná, apresentaram reação positiva à tuberculina ${ }^{110}$.

No Estado de Minas Gerais, a tuberculose no gado de corte era rara, sendo que, em 1944 havia 5,9\% de animais reatores à tuberculina, e nos anos 1948-51, apenas $972(0,15 \%)$ dos 664.369 animais examinados, estavam doentes. No mesmo período, o teste tuberculínico realizado em 1.852 vacas leiteiras, revelou apenas 12 $(0,64 \%)$ animais reagentes ${ }^{110}$.

Correa e Correa $(1972)^{79}$ isolaram 24 cepas de micobactérias, provenientes de lesões de bovinos colhidas em um matadouro da Grande São Paulo e de bovinos da Clínica de Enfermidades Infecciosas da Faculdade de Ciências Médicas e Biológicas de Botucatu. Entre as 24 cepas, 18 (75,0\%) eram M.bovis, 1 (4,2\%) M.tuberculosis e a outras $5(20,8 \%)$ pertencencentes à outras espécies de micobactérias. Os autores realizaram teste de sensibilidade aos tuberculostáticos e observaram que algumas cepas eram resistentes a antibióticos de $1^{\mathrm{a}}$ linha. Alertaram para o perigo existente no tratamento de animais, pois cepas artificialmente induzidas à resistência poderiam infectar todo o rebanho, constituindo uma ameaça à saúde pública ${ }^{79}$.

No período de 1973-1975, ocorreu um surto de tuberculose bovina em um rebanho de gado de corte, constituído por 1.832 animais em criação extensiva e provenientes de uma propriedade rural do Município de São Vicente do Sul, Rio Grande do Sul, no qual 36,6\% dos bovinos estavam doentes. Em 1975, 110 bovinos tuberculina-positivos pertencentes a este rebanho, foram abatidos na Cooperativa de Carnes de São Gabriel, sob inspeção federal. Foram colhidos 110 gânglios linfáticos com lesões tuberculóides e 15 amostras de músculos. O exame bacteriológico dos 110 gânglios permitiu o isolamento de 95 cepas $(86,0 \%)$ de micobactérias, posteriormente identificadas como M.bovis. Entretanto, a cultura dos músculos foi negativa, embora fosse material de animais com tuberculose generalizada, constatada no exame post mortem ${ }^{202,247 .}$

Em 1976, foi realizado outro estudo sobre a prevalência de lesões 
tuberculosas em bovinos de 7 municípios do Rio Grande do Sul, através do exame post mortem. Foram abatidos 28.197 animais, sendo que 1.488 (5,3\%) apresentaram lesões. A prevalência da tuberculose bovina nos 7 municípios, variou de 1,9\% a $10,9 \%{ }^{46}$.

Em 1978, a prevalência de tuberculose em 46 rebanhos leiteiros de 3 municípios de Mato Grosso do Norte, foi de $1,3 \%^{18}$. Neste ano, o Ministério da Agricultura constatou que a prevalência de tuberculose em rebanhos produtores de leite tipo B, da bacia leiteira em Belo Horizonte, Minas Gerais, era de 21,2\% ${ }^{172}$.

Em um estudo realizado em 1981, em gado leiteiro de 17 regiões do Rio Grande do Sul, efetuou-se o teste tuberculínico em 25.823 vacas, das quais 839 $(3,2 \%)$ eram tuberculina-positivas. A proporção de animais positivos ao teste variou de 0 a $6,3 \%$, entre as distintas regiões. Foram examinados um total de 2.206 rebanhos e $449(20,3 \%)$ apresentaram-se reatores positivos à tuberculina, indicando que a infecção tuberculosa no gado leiteiro alcançou taxas elevadas nas regiões estudadas $^{214}$.

O exame post mortem realizado em matadouros do Estado de São Paulo, em 1982, em 1.495.976 carcaças de bovinos procedentes de 611 municípios brasileiros, revelou que a tuberculose foi constatada em $5.334(0,36 \%)$ animais de 367 municípios (60,1\%). A prevalência de tuberculose variou de 0,23\% para o Estado de Mato Grosso a $0,49 \%$ para o Estado do Paraná ${ }^{232}$.

No período de janeiro de 1979 a 1983, estudou-se a prevalência da tuberculose bovina em animais abatidos no Frigorífico Triângulo em Uberlândia, Minas Gerais. Foram inspecionados 161.437 bovinos provenientes de vários municípios do sul do Estado de Goiás e Triângulo Mineiro, sendo que 267 animais suspeitos de estarem tuberculosos foram abatidos e submetidos ao exame post mortem. A prevalência da doença foi de $0,16 \%$ e os pontos de eleição, por ordem de aparecimento das lesões, foram os linfonodos do pulmão, carcaça, intestino, fígado, cabeça, língua e rins, havendo sido comprovados histopatologicamente os achados macroscópicos ${ }^{213}$. 
No período de 1980 a 1987, 159 lesões observadas em frigoríficos como macroscopicamente similares à tuberculose, provenientes de bovinos de 14 municípios da região sul do Rio Grande do Sul, foram estudadas histologicamente. A tuberculose foi diagnosticada em 147 lesões, e em 59 desses materiais foram realizadas culturas para micobactérias, obtendo-se 40 isolamentos tipificados como M.bovis. Neste período, estimou-se a prevalência da doença em gado de corte no Estado em aproximadamente $0,6 \%$, mas detectaram-se marcadas diferenças nas prevalências entre regiões, com variações de 0,1 a 3,4\%, provavelmente devidas a fatores sócio-econômicos e aspectos geográficos e climáticos ${ }^{5}$.

$\mathrm{Na}$ população bovina do Brasil, os resultados dos testes tuberculínicos realizados em 1986, em 4 regiões do país, mostraram variações no nível de infecção em torno de 0,9 a 2,9\%, enquanto 6,2 a $26,3 \%$ dos rebanhos testados possuíam animais reatores ${ }^{156}$.

Em 1990, Langenegger e col. (1991) ${ }^{169}$ realizaram um experimento em uma fazenda em Minas Gerais, cujo rebanho de gado leiteiro com 254 animais, acusou a presença de $55(21,7 \%)$ reagentes positivos à tuberculina e $13(5,1 \%)$ suspeitos para tuberculose ${ }^{169}$.

No período de 1986 a 1996 (sendo que os dados referentes ao período de 1994 a 1996 eram provisórios e não publicados, fornecidos pelo Ministério da Agricultura) a prevalência de infecção por M.bovis na população bovina do Brasil, variou de $0,9 \%$ a $1,7 \%$, em 14 Estados brasileiros ${ }^{188,189,190 .}$

Talvez, os números apresentados pelo Ministério da Agricultura estejam muito aquém da realidade, pois muitos veterinários autônomos deixam de notificar seus achados e ainda não foi feito um programa de controle da doença em nível nacional $^{200}$.

Para os pecuaristas, a tuberculose bovina gera conseqüências econômicas desastrosas, devidas em grande parte à aquisição de animais doentes, como a diminuição do desfrute do rebanho; redução da produção de leite e carne; desvalorização comercial do animal infectado pela rejeição de sua carcaça; maior 
intervalo entre partos; maior necessidade de substituição dos animais no rebanho; produção de crias debilitadas e diminuição do valor comercial da fazenda ${ }^{116}$.

Por isso, ainda hoje, apesar da pasteurização do leite e abate do gado tuberculina-positivo, se pratica o abate clandestino e o comércio clandestino de leite em várias regiões do Brasil, que são problemas difíceis de estimar. No caso da tuberculose, este fato é muito importante, pois alguns produtores de gado de leite e de corte, com altos índices de condenação por tuberculose, enviam seus animais para serem abatidos em locais sem controle sanitário. Além disso, é bastante frequiente a distribuição clandestina do leite proveniente de pequenas propriedades rurais $5,9,11$.

\subsection{2- OCORRÊNCIA NO HOMEM}

\subsubsection{1- No mundo}

A infecção humana pelo M.bovis foi primeiramente descrita no início deste século, onde se estimou que ela foi a causa de 10-18\% de todos os casos de tuberculose, existindo uma associação entre o número de casos humanos identificados e a prevalência da tuberculose na população bovina local 90, 248 . Calcula-se que 70 a $80 \%$ dos casos de tuberculose dos gânglios cervicais em crianças e $20 \%$ dos casos de tuberculose renal do homem eram causados pelo M.bovis ${ }^{282}$.

Existem vários relatos de casos de tuberculose humana pelo M.bovis, nos quais a causa mais comum tem sido a reativação endógena de infecções adquiridas na infância ou juventude, pela ingestão de leite não pasteurizado; ou por contato com gado doente, nas regiões que possuem uma alta incidência de infecção por M.bovis nos bovinos, sendo que nesses casos, a tuberculose é considerada uma doença ocupacional ${ }^{148,201,248}$.

Não é possível observar diretamente em populações humanas a prevalência da infecção pelo M.bovis, uma vez que nem o teste tuberculínico e nem qualquer outro método de investigação populacional pode distinguir essa infecção, daquela causada pelo M.tuberculosis ${ }^{175,216,236}$. No entanto, em 1992 o M.bovis era reconhecido como 
uma causa relativamente comum de tuberculose humana, sendo implicado em inúmeros casos que variavam de $0,1 \%$ na França a 5,0\% no Reino Unido ${ }^{36,41}$. Nos países (especialmente aqueles em desenvolvimento) onde a tuberculose no bovino era comum, cerca de $10,0 \%$ dos casos de tuberculose clínica em humanos eram causados pela infecção por M.bovis ${ }^{216}$.

Em 1909, Griffith na Inglaterra, relatou os primeiros 2 casos de tuberculose pulmonar causada pelo M.bovis. Desde então, tornou-se evidente que tuberculose pulmonar e extrapulmonar, devidas ao M.bovis, eram prevalentes no homem ${ }^{175}$.

Em 1928, Griffith reuniu os dados conhecidos na Grã-Bretanha sobre a frequiência do bacilo bovino na localização ósteo-articular, que foi de $20 \%$ entre os 598 doentes adultos, e de $33 \%$ em crianças abaixo de 5 anos de idade. Em 1929, o mesmo pesquisador procurou conhecer a importância da tuberculose bovina na epidemiologia humana, segundo a distribuição regional na Grã-Bretanha, e constatou que na Inglaterra, o bacilo bovino foi encontrado em 45,7\% dos casos de adenopatia cervical e em 18,2\% dos casos de localização ósteo-articular; entretanto, os números relativos à Escócia eram mais elevados: 70,6\% e 26,6\%, respectivamente. A prevalência de meningite por M.bovis, nessa época, na Inglaterra e País de Gales, era $30,2 \%{ }^{110}$.

Em 1929, Savage declarou na Inglaterra, que o M.bovis poderia causar todas as manifestações da tuberculose no homem. Nessa época, $5 \%$ de todos os casos de tuberculose eram devidos ao M.bovis, mas em crianças menores que 5 anos, a proporção era de $30 \%{ }^{228}$.

Savage também reviu a relativa proporção de tuberculose humana e bovina nos diferentes sítios de localização. O M.bovis foi isolado de $51 \%$ das lesões cutâneas, $45 \%$ das lesões cervicais, $32 \%$ dos casos de escrofuloderma, $27 \%$ dos casos de meningite, $18 \%$ das lesões ósteo-articulares, $17 \%$ das amostras gênito-urinárias, mas de apenas $1 \%$ das lesões pulmonares ${ }^{228}$.

Na década de 30, as taxas de incidência da tuberculose por M.bovis, variaram de 3 a $80 \%$, dependendo da forma da doença, influências regionais e exposicionais. 
Linfadenite cervical (escrófula) predominou em crianças; tuberculose extrapulmonar e, em menor grau, formas pulmonares, em adultos 148, 216 . Em 1932, os dados disponíveis sugeriram que cerca de $6 \%$ de todas as mortes por tuberculose eram causadas pelo bacilo bovino, ocorrendo 2.000 óbitos anualmente, sendo a maioria, constituída de crianças ${ }^{110}$.

Em 1937, o M.bovis foi isolado em cerca de $10 \%$ dos 7.500 casos de tuberculose humana, registrados na Grã-Bretanha ${ }^{175}$. Em um estudo detalhado, realizado por Griffith neste mesmo ano, na Inglaterra, dos 163 casos de doença pulmonar em humanos, devido a cepas bovinas, não foram demonstradas diferenças clínicas, radiológicas ou patológicas entre essas e a doença devida ao bacilo humano. Em 62 casos (38\%) havia evidências de um foco digestivo primário, mas nos outros 101 (62\%), a doença parecia estar limitada ao pulmão. Dos 163 pacientes, 25 $(15,3 \%)$ foram ocupacionalmente expostos ao gado e $21(12,8 \%)$ tinham uma história familiar de tuberculose ${ }^{125}$. Nesta época, a tuberculose bovina era responsável por mais de $25 \%$ de todos os casos de tuberculose humana, e cerca de $2 \%$ de tuberculose pulmonar $^{92}$.

Em 1937, 29,6\% dos casos de meningite e 51,6\% dos casos de adenite tuberculosa na Escócia, eram devidas ao bacilo bovino e em 1938, 24,6\% e 50,0\% respectivamente, eram de origem bovina na Inglaterra ${ }^{216,231}$.

A contribuição da infecção pelo M.bovis na taxa de mortalidade por tuberculose na Inglaterra, foi estimada em 3.382 mortes em 1918, 1.945 mortes em 1927 e 1.195 mortes em $1938^{228}$.

Em 1939, na Inglaterra, 1,4\% dos casos de tuberculose pulmonar foram estimados como sendo devidos ao M.bovis e, em 1944, essa porcentagem aumentou para $2,3 \%{ }^{110,148,216}$. O rápido aumento do número de casos de tuberculose pulmonar do adulto, pelo bacilo bovino, estimulou a intensificação das pesquisas em diversas regiões da Grã-Bretanha, e se constituiu em um dos argumentos mais consistentes, contra a tese da penetração do bacilo de Koch por via digestiva ${ }^{110}$.

No período de 1943 a 1945, 261 (26,3\%) dos 994 pacientes tuberculosos na 
Inglaterra, estavam infectados por M.bovis. Quanto à localização da doença, 28\% eram casos de meningite, $57 \%$ eram de adenopatia cervical e o restante, em outros locais. Um fato importante foi que a maior proporção dos casos não se encontrava no grupo etário de 0-4 anos, mas de 5-9 anos, talvez pela substituição gradual do leite cru, pelo leite fervido, na alimentação do lactente; ou pela distribuição de leite cru nas escolas, aumentando o risco de infecção para os escolares ${ }^{110}$.

No País de Gales, a prevalência de tuberculose por M.bovis foi menor (17\%), porque a pesquisa foi realizada em menor escala. Mas, reunindo os dados da Inglaterra e País de Gales, verificou-se que $24 \%$ de todos os casos de tuberculose extrapulmonar, foram devidos à infecção pelo bacilo bovino, e que em 1944, aproximadamente 1.350 pessoas morreram vitimadas por tuberculose extrapulmonar de origem bovina. A situação da Escócia continuava mais séria no período 1943-45, com a prevalência de tuberculose abdominal em 66,7\% dos casos nas cidades e $62,5 \%$, no campo, de adenite cervical em $46,2 \%$ e $77,8 \%$ e de meningite em $6,1 \%$ e $18 \%$, respectivamente. Em 1944, a prevalência de tuberculose pulmonar era de $5,8 \%{ }^{110}$.

A ausência de medidas eficazes para a redução de tuberculose no bovino ou para impedir a transmissão da doença ao homem, explicava porque a importância da tuberculose por M.bovis na epidemiologia humana mantinha-se inalterada, nessa época ${ }^{110}$.

Em muitos países da Europa, a tuberculose bovina foi altamente prevalente, particularmente, nos distritos rurais até 1950 ou mais ${ }^{175}$. Dados de prevalência da infecção tuberculosa no gado dessa época foram comparados com a prevalência de reações a tuberculina entre escolares anos depois, em alguns distritos rurais na Inglaterra. A porcentagem de reatores a tuberculina entre escolares de 13-14 anos de idade nos anos 1959-60, 1963-64, 1967-68, e a porcentagem de bovinos atestados como livres de tuberculose 12 anos antes (1947, 1951 e 1955 respectivamente) em 41 distritos rurais da Inglaterra foram analisados. Encontrou-se que quanto menor exposição havia ao gado tuberculoso, menor era a porcentagem de reatores nos escolares, indicando que uma substancial proporção dos reatores a tuberculina entre 
as crianças resultou de uma infecção por fonte bovina ${ }^{92,148,175,216 .}$

Apesar de não serem fornecidas estimativas exatas, os resultados sugeriram que a maior proporção da população rural inglesa, reagente à tuberculina, era constituída de pessoas nascidas antes de 1950 e, provavelmente, sensibilizadas através do contato, direto ou indireto, com bovino tuberculoso ${ }^{175}$. Este estudo auxiliou na explicação da contínua presença do M.bovis entre a população adulta atualmente no Reino Unido 92, 148 . Essas pessoas constituem um imensurável reservatório para reativação, uma vez que são portadores de bacilos viáveis, mas dormentes $^{1,129}$.

No período de 1962-1966, o M.bovis foi isolado de 102 pacientes tuberculosos na Inglaterra e País de Gales, sendo 65 casos pulmonares, 37 não pulmonares e 25 destes, envolvendo o trato urinário ${ }^{125,127}$. Em Liverpool, encontrouse uma incidência de 2,9\% da infecção causada por M.bovis, no período de 1969 a $1983^{1,288}$. Neste período, o M.bovis era responsável por cerca de 2,0\% de todos os isolamentos micobacterianos em pacientes humanos no noroeste da Inglaterra $^{92,148,216}$.

Entre 1977 e 1987, Yates e Grange constataram que dos 16.862 casos de tuberculose registrados no sudeste da Inglaterra, $201(1,2 \%)$ foram causados por M.bovis, sendo $40 \%$ dos casos de localização pulmonar e a idade média dos pacientes, em torno dos 62 anos de idade 1, 84, 92, 225, 298 . Neste período, estimou-se que o M.bovis era responsável por cerca de $1 \%$ de todos os isolamentos micobacterianos de pacientes humanos no sudeste da Inglaterra e País de Gales $^{92,148,216}$. Em um estudo realizado entre 1980 e 1989, dos 1.817 casos de linfadenite tuberculosa que ocorreram no sudeste da Inglaterra, o M.bovis foi isolado de $25(1,4 \%)$ pacientes ${ }^{1}$.

No período de 1977 a 1990, de um total de 20.361 novos casos de tuberculose, registrados também no sudeste da Inglaterra, $232(1,1 \%)$ eram causados por M.bovis, sendo 94 casos (40\%) de doença pulmonar e 138 (60\%) de casos extrapulmonares, dos quais $53(38 \%)$ foram de localização gênito-urinária ${ }^{127}$. 
Durante o período de 1986 a 1990, M.bovis foi isolado de 228 pacientes tuberculosos identificados nos Laboratórios de Saúde Pública na Inglaterra e País de Gales. Doença respiratória foi encontrada em 78 (34\%) dos 228 isolamentos; doença não respiratória ocorreu em 123 (54\%) pacientes, e os isolamentos remanescentes eram de casos onde o sítio da doença era desconhecido. Isolamentos de 50 (22\%) dos 228 pacientes eram do trato gênito-urinário. Quanto à faixa etária atingida, 54\% eram pacientes com idade superior a 60 anos; $25 \%$ entre 30-60 anos e 3,5\% abaixo de 30 anos. Os remanescentes eram pacientes com idade desconhecida ${ }^{148,216}$. No período de janeiro de 1986 a outubro de 1991, foram registrados 9.687 isolamentos de micobactérias sendo que 117 (1,2\%) foram devidos ao M.bovis, e destes, 34\% foi de doença pulmonar ${ }^{84,148}$.

Na Escócia, no período de 1986 a 1991, a tuberculose humana devida ao M.bovis foi responsável por $2 \%$ dos casos de tuberculose notificados, dos quais $54 \%$ eram de localização não-pulmonar e $76 \%$ em pessoas com idade superior a $65 \operatorname{anos}^{57}$.

Durante um surto de tuberculose em 2 rebanhos de bovinos, ocorrido no sudoeste da Escócia em 1992, 17 pessoas apresentaram viragem tuberculínica e foram submetidos à quimioprofilaxia com isoniazida. Todos eram trabalhadores ou famílias que viviam nas 2 fazendas, onde os surtos ocorreram, e que haviam sido expostos diretamente aos bovinos doentes 57 .

Em 1992, estimou-se que o M.bovis era responsável por apenas 1\% de todos os isolamentos micobacterianos de pacientes humanos reportados na Inglaterra e País de Gales. Cerca de 20 a 40 casos de infecção por M.bovis em humanos, foram confirmados a cada ano nesses países 148, 216. Muitos casos foram de doença reativada, mas alguns isolamentos ocorreram em pacientes nascidos depois da implantação das medidas de controle representando uma infecção primária adquirida de bovinos ou humanos ${ }^{148}$. Na Inglaterra, apesar dos esforços de profissionais médicos e veterinários, a pasteurização obrigatória obteve pequenos progressos, devido à preferência pública por leite cru ${ }^{201,228}$. Desde $1988,3,0 \%$ de todo o leite da Inglaterra e País de Gales, ainda não é pasteurizado ${ }^{57,148,228 .}$

$\mathrm{Na}$ Dinamarca, em um período de 5 anos (1931-36), 5.476 cepas de bacilo da 
tuberculose, de todos os casos existentes no país na época, foram tipificadas por Jensen e col., e $644(11,8 \%)$ eram M.bovis. Entre os casos pulmonares, a porcentagem de infecção bovina foi de 5,4\% e entre os extrapulmonares, 25,1\%. Dos 29 casos de meningite que ocorreram em crianças abaixo de anos de idade nos distritos rurais, $23(79,2 \%)$ eram de origem bovina ${ }^{110,266}$.

Em 1940, um estudo realizado por Jensen e col. demonstrou que 23,4\% dos casos de tuberculose meníngea e 46,2\% dos casos de tuberculose glandular, eram devidos ao M.bovis, e que a freqüência da tuberculose bovina no homem variava, em diferentes partes do país, com a freqüência da tuberculose no gado e com o hábito das pessoas de ingerirem leite cru. Numerosos casos de doença pulmonar bovina ocorreram entre adultos que trabalhavam com gado, sugerindo a importância da infecção por inalação ${ }^{110,231,266 .}$

Em 1956, uma enfermeira nascida em 1917, foi hospitalizada em Copenhague. Ela era filha de um fazendeiro que na época do seu nascimento estava sendo tratado de tuberculose, e numerosas vacas tuberculosas estavam sendo abatidas em sua propriedade. Apesar de não ter estado em íntimo contato com esses animais, ela desenvolveu tuberculose por M.bovis. Esse caso ilustra uma exacerbação endógena tardia de uma antiga e quiescente infecção bovina ${ }^{266}$.

Magnus $(1963,1966)^{183,184}$ estudou o problema da prevalência de infecção por M.bovis, por meio de um modelo matemático, baseado na correlação entre a prevalência da infecção tuberculosa em humanos e no gado, em 20 regiões dinamarquesas. Foi possível estimar para cada região a proporção da população humana infectada com cada um dos 2 tipos de bacilos, humano e bovino. Magnus comparou a frequiência de rebanhos bovinos infectados nos anos 1937-39, para cada região, com a prevalência de pessoas tuberculina-positivas em uma campanha de massa realizada no período 1950-52. Concluiu que, uma enorme proporção dos reatores à tuberculina na população dinamarquesa, adquiriu sua reação através da exposição ao gado tuberculoso no passado, e que os reatores de fonte bovina, tinham um menor risco de desenvolverem tuberculose pulmonar do que os reatores que adquiriram sua infecção pela exposição a humanos tuberculosos $127,175,183,184,216$. 
Magnus foi de opinião que na Dinamarca, a rota digestiva da infecção, via leite contaminado, provavelmente justificou a baixa freqüência de doenças pulmonares, e possivelmente também, a baixa morbidade entre os reatores infectados por fontes bovinas $127,175,184,216$.

No entanto, outros estudos demonstraram que na Dinamarca, onde o programa de erradicação da tuberculose bovina começou antes que em muitos outros países da Europa, o número de casos pulmonares em humanos, entre o total de casos devidos ao M.bovis, aumentou no decurso de muitas décadas, sendo 30,7\% em 1931$35,49,7 \%$ em $1954-58$ e $58,3 \%$ em $1959-63^{127}$.

Para o país como um todo, cerca de um terço de todas as pessoas nascidas entre 1910 e 1930, que reagiram à tuberculina em 1972, tinham sido infectadas por fontes bovinas somente, apesar da tuberculose no gado haver sido considerada completamente erradicada na Dinamarca em 1952 154, 175, 184, 216, 266.

Na Alemanha, em 1932, a freqüência do bacilo bovino na tuberculose humana era a seguinte: $8,6 \%$ de 201 casos de tuberculose generalizada e meningite tuberculosa; 4,6\% de 87 casos de tuberculose ósteo-articular; 22,3\% de 94 casos de adenopatia cervical; 35,8\% de 106 casos de tuberculose abdominal; mais de $1 \%$ de 345 casos de tuberculose pulmonar; e nenhum caso, entre os 24 de tuberculose gênito-urinária. Em pessoas cujas ocupações as obrigavam ao contato com vacas tuberculosas, a prevalência da infecção por M.bovis girou em torno de $20,0 \%{ }^{110}$.

Durante o período de 1953 a 1957, foram examinadas 4.784 cepas de bacilos da tuberculose provenientes de pacientes adultos, e o M.bovis foi isolado de $5 \%$ dos casos de tuberculose pulmonar e $14 \%$ dos casos de tuberculose extrapulmonar ${ }^{68,141}$.

Na Suécia, no período de 1936 a 1939, ocorreram 94 casos de tuberculose humana devida ao M.bovis, e nos anos 1974-75, foram registrados 12 casos de infecção humana, pelo bacilo da tuberculose bovina ${ }^{127,261}$. Desde 1984, a cada ano, aproximadamente 10 casos de tuberculose por M.bovis foram diagnosticados na Suécia. Esses casos ocorreram principalmente em pessoas mais velhas, resultantes da ativação de infecções persistentes, e em imigrantes de países com altas prevalências 
de tuberculose no gado ${ }^{40,160}$.

Na França, Gervois em 1937, demonstrou que 7,4\% dos casos de tuberculose meníngea e $11,0 \%$ dos casos de tuberculose glandular, eram de origem bovina ${ }^{231}$.

No período de 1954 a 1966, o trabalho de estatística geral publicado por Gervois em 1966, e citado por Corrêa e Corrêa em 1974, demonstrou as seguintes incidências do bacilo bovino no homem: Alemanha, 10,5\%; Inglaterra, 4,7\%; Dinamarca, 5,6\%; França, 4,3\%; Polônia, 1,1\%; Hungria, 9,9\%; Suíça, 2,6\%; Checoslováquia, 7,8\%; Turquia, 7,1\%; Congo, 2,2\%; África do Sul, 7,2\% e Venezuela, $5,4 \%{ }^{81}$.

Este mesmo trabalho mostrou as seguintes porcentagens para a distribuição das lesões no doente: pleuro-pulmonares, 3,3\%; cutâneo-mucosas, 41,7\%; adenites cervicais, 31,2\%; meníngeas, 13,2\%; peritoniais, 8,0\%; ósteo-articulares, 7,3\% e gênito-urinárias, $5,2 \%{ }^{81}$.

No período de 1988 a 1993, foram identificadas 85 cepas de M.bovis em humanos, na França. O modo de contaminação foi principalmente aerógeno, porque $68 \%$ dos pacientes apresentavam tuberculose pulmonar ${ }^{275}$.

Em 1993, ocorreu um caso de tuberculose miliar por M.bovis em um hospital na França, em uma mulher de 75 anos de idade, não exposta a riscos alimentares ou profissionais, e nem imunodeficiente. Houve, inicialmente, uma localização pulmonar e urinária do bacilo, com posterior disseminação hematogênica. Usualmente, o M.bovis é responsável por tuberculose pulmonar em pacientes expostos profissionalmente, e as formas disseminadas ocorrem, com maior freqüência, em pessoas imunodeprimidas. Para esta paciente, suspeitou-se de uma reativação de uma infecção antiga ${ }^{104}$.

Na Holanda, em 1936, o M.bovis foi responsável por 14,3\% dos casos de tuberculose infantil e $5 \%$ dos casos em adultos ${ }^{110}$. De 1972 a 1975, os laboratórios de microbiologia holandeses registraram 125 infecções por M.bovis em seres humanos, sendo que mais de $80 \%$ dos pacientes haviam nascido na época em que a infecção por M.bovis, proveniente do leite, era possível. Seis pacientes eram menores 
de 20 anos, presumivelmente infectados em outros países, e um paciente havia nascido em 1954, quando a tuberculose bovina ainda não estava erradicada na Holanda ${ }^{67}$.

No Hospital de La Santa Cruz y San Pablo de Barcelona, na Espanha, durante o período de 1986 a 1990, foram diagnosticados 10 casos de tuberculose atribuída ao M.bovis, cuja incidência foi de $0,9 \%$. Os pacientes tinham em média, 32 anos de idade. Doença pulmonar foi observada em 5 (50\%) pacientes, linfadenite em $2(20 \%)$, derrame pleural em $2(20 \%)$ e derrame peritonial em $1(10 \%)$ deles. O mais significante dos fatores epidemiológicos foi que 2 desses pacientes, de 18 e 22 anos respectivamente, eram estudantes de veterinária ${ }^{216,248}$. Este fato sugere que talvez os veterinários pertençam ao grupo de alto risco, necessitando de medidas de vigilância e controle ${ }^{248}$.

Na Irlanda, O'Kelly estimou em 1918, que 10\% dos casos de tuberculose em humanos, eram devidos ao M.bovis. De 1929 a 1938, aproximadamente 31-33\% de todo o gado da cidade de Dublin estavam tuberculosos, e Mushatt constatou, em 1940, que 34\% dos casos de tuberculose não-pulmonar em humanos, na Irlanda, eram de origem bovina ${ }^{85}$.

Em 1941, foi reportado que dos 72 casos de tuberculose, investigados na Irlanda do Norte, 14 (19,4\%) eram causados por M.bovis. Dos 29 casos de meningite, e 16 casos de adenite cervical, $7(24,1 \%)$ e 2 (12,5\%), respectivamente, eram causados por M.bovis. Não foram descobertos casos de tuberculose pulmonar por esse agente ${ }^{216,231}$.

Se as mortes por tuberculose abdominal em crianças abaixo de 5 anos de idade era considerada uma consequiência da ingestão de leite cru infectado com M.bovis, a dramática queda de 1107 mortes em 1921 para 12 mortes em 1953, foi devida à combinação da pasteurização do leite e controle da tuberculose no bovino $^{148,216}$.

Um levantamento nacional sobre tuberculose, realizado no período de 195053 na Irlanda, atribuiu 10,4\% dos casos de tuberculose extrapulmonar ao M.bovis, e 
apenas $1 \%$ dos casos de tuberculose pulmonar ${ }^{85}$.

No período de janeiro de 1982 a dezembro de 1985, na República da Irlanda foram diagnosticados 1.002 casos de tuberculose, sendo que $9(0,9 \%)$ eram devidos ao M.bovis ${ }^{216}$.

Durante os anos 1986 a 1990, o M.bovis foi responsável por 6.4\% dos casos de tuberculose existentes na região oeste da Irlanda, que é considerada uma área predominantemente rural. O estudo incluiu 331 isolamentos, sendo 263 cepas pertencentes ao complexo M.tuberculosis e 68 MOTT. Dos 263 casos de tuberculose, causados pelo complexo M.tuberculosis, 17 (6,5\%) foram devidos ao M.bovis. Desses 17 casos, 12 (70,6\%) eram de localização pulmonar, 5 (29,4\%) de localização extrapulmonar e $4(23,5 \%)$ cepas, eram resistentes à isoniazida e pirazinamida ${ }^{76,84}$.

$\mathrm{Na}$ Irlanda do Norte, estudos realizados durante 13 anos, de 1979 a 1991, registraram a ocorrência de menos que 2 casos de tuberculose por M.bovis, por ano, refletindo o impacto da pasteurização do leite e dos programas de erradicação da tuberculose bovina, introduzidos na década de $50^{84}$.

Cotter e col. (1996) $)^{84,} \quad 85$ estudaram os aspectos bacteriológicos e epidemiológicos da doença humana por M.bovis, nas regiões de Cork e Kerry, no sudoeste da Irlanda, nos anos 1983-92, inclusive. Entre os 626 casos de tuberculose ocorridos na região, nesse período de 10 anos, 30 (4,8\%) eram devidos ao M.bovis, sendo que $16(53,3 \%)$ casos eram de origem pulmonar e $14(46,7 \%)$ de localização extrapulmonar, com tuberculose gênito-urinária constatada em 4 (28,6\%) dos 14 pacientes extrapulmonares. A idade média dos pacientes foi de 58,4 anos, e 63,4\% dos casos de M.bovis ocorreram em pessoas do sexo masculino. Como não houve diferença na incidência da doença, em pacientes de origem urbana ou rural, os autores sugeriram que a infecção inicial ocorreu na infância através de leite contaminado, na era pré-pasteurização, e que possivelmente, alguns adquiriram a infecção por aerolização primária de um bovino ou humano infectado ${ }^{84,85}$.

Um estudo posterior dos mesmos autores e realizado na mesma região, na qual existia um foco residual de tuberculose humana por M.bovis, comparou a 
incidência da doença em humanos com culturas positivas para M.bovis entre 1983 e 1994, com os resultados da prova tuberculínica no gado entre 1978 e 1994. Observaram que a cada ano houve o registro de 1 a 5 casos humanos de tuberculose por M.bovis, apesar da diminuição gradual da prevalência da doença nos bovinos, durante o período estudado ${ }^{85}$.

A baixa incidência da enfermidade humana e a diminuição da prevalência da infecção animal sugeriram um corte na cadeia de infecção do animal ao homem em dois níveis: o foco animal e a ingestão de leite não pasteurizado, indicando que a doença em humanos era devida à reativação de focos prévios da infecção, na época em que a pasteurização do leite não era obrigatória. Baseados nessas observações, os autores acreditam em uma possível eliminação da doença humana por M.bovis, nesta região, em 10 a 15 anos ${ }^{85}$.

Em Ontario, Canadá, dos 500 casos de tuberculose infantil estudados por Price, no período de 1926 a 1938, 9.6\% eram causados por M.bovis ${ }^{92,110}$. Em 1939, todos os municípios, dentro dos limites de Ontario, usavam leite pasteurizado. $\mathrm{O}$ sucesso desse plano de erradicação foi melhor demonstrado por um estudo de 31 casos de tuberculose bovina registrados entre 1964 e 1970, no qual 75\% dos pacientes infectados tinham acima de 40 anos de idade, e nenhuma criança havia sido afetada. Esses 31 pacientes representaram apenas 0,5\% de todos os casos de tuberculose humana nesse período. Treze $(41,9 \%)$ pacientes tinham doença pulmonar e $18(58,1 \%)$ extrapulmonar, dos quais $12(66,7 \%)$ entre os 18 casos de tuberculose não-pulmonar apresentavam envolvimento do trato gênito-urinário ${ }^{92,108,125,127,216,283}$. Em 1982, somente $4(0,5 \%)$ dos 743 novos casos de tuberculose ocorridos em Ontario, eram devidos ao M.bovis ${ }^{92}$. No período de 1973 a 1990, dos 14.731 isolamentos de micobactérias identificadas, apenas $57(0,4 \%)$ eram M.bovis ${ }^{179}$.

Nos Estados Unidos, estudos epidemiológicos foram concentrados nos Estados do leste, provavelmente devido à densidade populacional e aos grandes rebanhos leiteiros mantidos nessas áreas. No período de 1927 a 1931, em Nebraska, 9 (40\%) dos 227 casos de tuberculose humana eram causados por M.bovis. Em 1933, em um sanatório de Boston, 27,5\% de todos os casos de tuberculose, eram devidos ao 
M.bovis ${ }^{92}$.

No período de 1979 a 1983, nos Estados Unidos, constatou-se uma média de 26 isolamentos/ano de M.bovis, com uma taxa menor que $0,1 \%$ de todas as espécies micobacterianas registradas no $\mathrm{CDC}^{92}$.

Outros dados do San Diego County Department of Health Services em San Diego, revelaram uma taxa de isolamento de M.bovis 2,6\% em $1991{ }^{68,167}$. Estes valores poderiam subestimar o número de infecções por M.bovis, uma vez que o denominador representava todos os pacientes com tuberculose, incluindo os não confirmados bacteriologicamente ${ }^{92}$.

Em San Diego, houve 73 casos de tuberculose bovina em humanos, no período de 1980 a $1991^{\text {92, } 216}$. Desse total, 48 eram adultos, sendo 22 mulheres (com idade média de 39 anos) e 26 homens (idade média de 37 anos), além de 25 crianças e adolescentes (idade inferior a 16 anos). Quanto à localização das lesões, entre os adultos, $24(50 \%)$ apresentaram doença pulmonar e os outros 24 (50\%) doença extrapulmonar, principalmente nos homens ${ }^{85,92}$.

A maioria dos adultos (69\%) era de origem hispânica, nascidos no México ou nos Estados Unidos, com freqüentes períodos de residência ou viagens ao México, país que nessa época, possuía $50 \%$ do gado leiteiro infectado com tuberculose ${ }^{85,92}$.

Entre os 25 pacientes pediátricos (idade média de 3 anos, incluindo 2 adolescentes) haviam 13 meninas e 12 meninos, sendo que 11 (44\%) apresentaram linfadenite cervical, 3 (12\%) doença pulmonar e os outros 11 (44\%) com manifestações extrapulmonares. Um dos adolescentes era aidético. A exemplo dos adultos, a maioria dos pacientes pediátricos $(80 \%)$ era de origem hispânica ${ }^{92}$.

A distribuição anual dos 73 casos de infecção por M.bovis em San Diego demonstrou que a maioria dos pacientes $(60 \%)$ foi identificada durante os últimos 3 anos do estudo (1989-1991), sendo que 12 (27,3\%) pacientes, pertencentes a esse grupo de 44 identificados desde 1989, estavam infectados com HIV ${ }^{85,92}$.

Este estudo sugeriu que a infecção pelo HIV e a contínua imigração irão, 
provavelmente, aumentar o número de pessoas com tuberculose bovina, no futuro $^{85,92}$.

Em 1996, ainda 0,1\% dos casos de tuberculose humana eram causados pelo M.bovis, uma taxa similar a de outros países onde a tuberculose no bovino tinha sido virtualmente erradicada; mas a proporção elevava-se para 3\%, perto da fronteira com o México, onde casos de doença no gado ainda eram comuns ${ }^{196}$.

No período de 1983-1990, ocorreram 305 casos de tuberculose humana no Wellington Hospital da Nova Zelândia, dos quais 22 (7,2\%) foram causados pelo M.bovis. A idade média dos pacientes sugeriu uma infecção mais recente e não uma reativação, e a alta proporção de homens infectados indicou alguma atividade ocupacional ou de recreação, como a captura de gambás e a caça. Considerou-se improvável que o aumento nos casos de infecção fosse devido a ingestão de carne ou leite contaminados, uma vez que o pulmão foi o órgão mais atingido, sugerindo outra rota de transmissão ${ }^{45}$.

Em 1995, em um hospital de Adelaide, Austrália, ocorreu um caso de meningite causada por M.bovis em uma mulher de 57 anos de idade, que havia emigrado da Inglaterra em 1950. Como o diagnóstico da meningite tuberculosa é muito difícil, apesar de terem realizado uma punção do líquor, a mulher faleceu após 3 semanas de hospitalização e o M.bovis só foi isolado 7 dias depois ${ }^{212}$. Em uma revisão sobre meningite tuberculosa na Austrália, não houve qualquer registro de casos devidos à cepas de M.bovis. Até 1995, o M.bovis era responsável por $1 \%$ de todos os casos de tuberculose humana, registrados na Austrália ${ }^{221}$.

Na Eslováquia, onde a doença no bovino foi eliminada em 1968, durante o período de 1972 a 1990, foram descobertos 68 novos casos de tuberculose em humanos, causados por M.bovis. Muitos casos ocorreram na faixa etária de 65 anos de idade ou mais, principalmente em pessoas que foram expostas à infecção no período anterior à eliminação da tuberculose no bovino ${ }^{19,85}$. Aproximadamente $80 \%$ das pessoas infectadas viviam em aldeias e apenas $20 \%$ em cidades com mais de 10.000 habitantes. Metade das pessoas era aposentada e quase $90 \%$ delas e das não aposentadas haviam trabalhado na agricultura. Dos 68 casos, 60 (88,2\%) 
apresentaram tuberculose pulmonar e $8(11,8 \%)$, extrapulmonar ${ }^{19}$.

No Egito, estudos demonstraram que, das 300 micobactérias cultivadas de escarros humanos, $15(5 \%)$ eram M.bovis. A alta ocorrência foi atribuída ao fato de que muitos pacientes residiam em uma área de matadouros no Cairo, e alguns deles trabalhavam naqueles locais. Outros autores citaram que de 20 cepas de micobactérias isoladas de pacientes com tuberculose abdominal, 9 (45\%) eram M.bovis, embora dados de 1996 tenham sugerido que a prevalência de tuberculose humana causada pelo M.bovis no Egito, variava de $0,4 \%$ a $6,0 \%$ em diferentes hospitais do país ${ }^{196,295}$.

Existem pouquíssimas informações a respeito da prevalência da tuberculose humana causada por M.bovis na África e os dados disponíveis, geralmente, são provenientes de amostras populacionais pequenas e não representativas. Entretanto, as informações baseadas nos registros de inspeção de carne e testes tuberculínicos, realizados em alguns países africanos, sugeriram que a tuberculose bovina era extensamente prevalente na África, e em algumas áreas, a prevalência era excepcionalmente alta, expondo a população humana a um grande risco de contrair a infecção por M.bovis ${ }^{90}$.

Acredita-se haver uma correlação positiva entre a quantidade de cabeças de gado em uma região e a prevalência de tuberculose humana não pulmonar. Esta crença foi reforçada por Alemu, que em 1992 declarou que na Etiópia, a prevalência de tuberculose em uma tribo pastoril foi de 55\% em comparação aos $10 \%$ encontrados em tribos não pastoris ${ }^{89}$.

Em 1992, Bakunzi e col. $(1995)^{20}$, realizaram um estudo de 6 meses no distrito de Malopo, na África do Sul, onde a população local tradicionalmente consome leite cru ou azedo (coalhado). A média de incidência da tuberculose humana por M.bovis foi $0,2 \%$, considerada relativamente alta uma vez que a incidência no bovino havia sido de apenas $0,06 \%$, levantando a suspeita de que os bovinos provavelmente não foram os principais contribuintes para a tuberculose humana neste distrito ${ }^{20}$. 
Em março de 1994, das 19 biópsias de linfonodos, obtidas de pacientes da região de Arusha, Tanzânia, foram isoladas 4 (21,1\%) cepas de M.bovis. Os pacientes eram de uma zona rural, por isso, 2 casos ocorreram em tratadores de gado, 1 caso em um fazendeiro e o outro em 1 criança. No final de 1994, foram isoladas 44 cepas de micobactérias em seres humanos na Tanzânia, sendo que 11 (25\%) delas foram identificadas como M.bovis ${ }^{90}$.

Fison (1996) ${ }^{114}$ relatou que, no sul do Sudão, existia pouca informação sobre a prevalência de tuberculose no gado, mas que em pelo menos uma região, havia uma alta taxa de tuberculose extrapulmonar na população humana, e que casos de tuberculose bovina eram encontrados com freqüência no gado submetido ao exame post mortem. Existia um íntimo contato entre a população humana e seus animais, fossem bovinos ou animais domésticos, e por isso, o leite era consumido cru ou coalhado, dificultando muito o controle da doença ${ }^{114}$.

Nas Américas (América do Norte, América Latina e Caribe), segundo dados de 1992, registravam-se anualmente quase 8.000 casos de infecção humana por M.bovis ${ }^{217,235}$.

No Peru, um estudo de 853 cepas do bacilo da tuberculose provenientes de casos de tuberculose pulmonar em humanos, identificou 38 (4,5\%) cepas como M.bovis ${ }^{216}$.

Na Argentina, em 1904, foram descritos os primeiros casos de tuberculose humana produzida pelo bacilo bovino, baseando-se no isolamento do M.bovis em lesões intestinais de crianças mortas por tuberculose ${ }^{74,110,154,156}$. Outros casos de tuberculose infantil de origem bovina foram descritos em 1912, e em 1940 ocorreu um caso de primo-infecção tuberculosa pulmonar causada pelo M.bovis, em um auxiliar de veterinário que inspecionava matadouros ${ }^{74,110,154}$, e outro em 4 adultos que também exerciam atividades em matadouros ou frigoríficos, sendo que um deles contaminou um filho de 23 meses de idade, em cujas fezes foi isolado o bacilo ${ }^{110}$. Durante a década de 40, o M.bovis era responsável por cerca de $6 \%$ dos casos de tuberculose humana, na Argentina 192, 216. 
Raimondi e col., em 1940, investigaram 60 trabalhadores do Matadouro e Frigorífico Municipal de Buenos Aires que apresentaram tuberculose pulmonar e encontraram que em $4(6,7 \%)$ deles, o agente causal havia sido o bacilo do tipo bovino. Na pesquisa familiar dos 4 pacientes, descobriram 1 menino com uma lesão gânglio-pulmonar causada também pelo M.bovis $^{74,110}$.

Em 1946, Arena e Cetrángolo relataram que, de 86 cepas de micobactérias isoladas de trabalhadores rurais com tuberculose extrapulmonar, $5(5,8 \%)$ eram M.bovis; e de 140 cepas isoladas de pacientes com tuberculose pulmonar, $8(5,7 \%)$ eram M.bovis ${ }^{74,154}$.

Em 1970 e 1971, de 215 cepas de micobactérias isoladas de pacientes com tuberculose, em um primeiro estudo, 8 (3,7\%) foram classificadas como M.bovis. Em um segundo estudo sobre uma amostra maior (1.800 cepas em 3 anos), 27 (1,5\%) foram M.bovis ${ }^{74,154}$. Em 13 desses casos confirmou-se a existência de recente contato com animais em tarefas rurais ou em frigoríficos; em outros 4 a ocorrência de reativação endógena; e nos 10 pacientes restantes não haviam antecedentes rurais, sendo que em um deles se comprovou uma fonte de contágio familiar ${ }^{154}$.

Na província de Santa Fé, durante o período 1977-1989, o M.bovis foi isolado de 66 pacientes $(2,7 \%)$ de um total de 2.482 casos de tuberculose. A idade média dos pacientes foi 44 anos, e 63,8\% deles eram trabalhadores rurais ou empregados de frigoríficos ou matadouros. Em 65 (98,5\%) dos 66 pacientes, a localização da tuberculose foi pulmonar e apenas $1(1,5 \%)$ apresentou tuberculose ganglionar ${ }^{170,216}$.

Entre 1982 e 1984, um levantamento bacteriológico de âmbito nacional foi realizado na Argentina, onde 7.700 amostras de escarros de pacientes com tuberculose pulmonar foram analisadas. O M.bovis foi identificado em escarros de apenas $49(0,6 \%)$ desses pacientes. A prevalência de infecção atribuída ao M.bovis variou de zero a $1,9 \%$, com uma média de $0,4 \%$, de acordo com a região ${ }^{156,216}$.

Durante o período de 1983 a 1993, 66 casos de tuberculose humana causada pelo M.bovis foram diagnosticados pela cultura de escarro ou outros fluidos corporais no Hospital do Instituto de Doenças Respiratórias e Tuberculose da Universidade de 
Buenos Aires. A incidência, em relação aos casos de M.tuberculosis diagnosticados no mesmo período, foi $0,9 \%$. A idade média dos pacientes foi 39,4 anos. Doença pulmonar foi observada em 53 pacientes $(80,3 \%)$ e derrame pleural em $13(19,7 \%)$. Do ponto de vista epidemiológico, o aspecto mais significativo foi que 19 pacientes trabalhavam em matadouros, 18 beberam leite não pasteurizado e 2 eram pacientes HIV-positivos. Houve 4 mortes, 12 casos com retratamento e 50 pacientes tiveram uma boa evolução com o tratamento ${ }^{198}$.

Neste país, onde uma relativamente alta prevalência de tuberculose no bovino coincide com um diagnóstico bacteriológico confiável de doenças humanas, a porcentagem de casos de tuberculose humana devida ao M.bovis variava de 0,4 a 6,2\%, entre 1992 e 1995, e muitos dos pacientes infectados eram trabalhadores rurais ou de matadouros 216,235 .

\subsubsection{2- No Brasil}

Dados sobre a prevalência da tuberculose humana causada pelo M.bovis no Brasil são desconhecidos. Sabe-se apenas que a incidência era elevada nas primeiras décadas deste século, como acontecia também na Europa. Há, entretanto, referência de um caso na Guanabara (Rio de Janeiro) em 1938, cujo paciente apresentava alterações intestinais intensas. No Rio Grande do Sul, em 1940, foram identificados 4 casos; em São Paulo, em 1941, foram isoladas 16 (13,2\%) cepas de M.bovis em 121 pacientes com meningite tuberculosa, e em Minas Gerais, em 1955, de um total de 52 doentes, foram isoladas 2 (3,8\%) cepas de M.bovis ${ }^{4,110}$.

Outro caso de tuberculose por M.bovis, descrito por Andrade e col. (1972) ${ }^{4}$, ocorreu na Guanabara em 1968, em um homem de 39 anos de idade, que havia trabalhado como lavrador até os 18 anos, e que apresentava tuberculose pulmonar. Após 5 meses de tratamento o paciente teve alta do hospital por abandono e em 1971 apresentava-se como crônico, com poucas possibilidades de cura ${ }^{4}$.

Em São Paulo, no período de setembro de 1970 a outubro de 1973, 200 cepas de micobactérias foram isoladas de diferentes casos de humanos, com diagnóstico clínico de tuberculose, sendo que 7 (3,5\%) cepas de M.bovis foram encontradas. A 
tuberculose pulmonar foi responsável por $5(2,5 \%)$ casos e a tuberculose renal por 2 $(1,0 \%)^{81}$.

\subsection{3- OCORRÊNCIA NOS RESERVATÓRIOS ANIMAIS}

O M.bovis possui uma das maiores cadeias de hospedeiros entre todos os patógenos existentes, com um complexo padrão epidemiológico, que envolve interações da infecção entre seres humanos, animais domésticos e animais selvagens ${ }^{199}$. Há um consenso geral entre os pesquisadores, que a tuberculose é relativamente rara em animais selvagens, com a exceção dos locais onde exista a possibilidade de um contato prévio com bovinos e humanos ${ }^{208}$.

O M.bovis tem um amplo espectro de patogenicidade para várias espécies domésticas e silvestres, constituindo-se a principal causa da tuberculose $\operatorname{animal}^{65,87,89,92,196,199,201,256}$. A infecção por este agente tem sido reportada em um grande número de espécies animais, que constituem um foco potencial para a doença no homem e em outras espécies animais, possibilitando a persistência da tuberculose bovina no mundo, pela falta de testes diagnósticos confiáveis e o efetivo tratamento de espécies não domésticas $25,87,89,92,125,201,203,228,237,256,261$.

Entre os animais infectados, encontram-se os domésticos (gatos, cachorros, suínos), mamíferos exóticos e silvestres, alguns cativos em zoológicos e parques animais, e outros animais selvagens, tais como: macacos, elefantes, girafas, leões, tigres, leopardos, raposas, camelos, lhamas, alpacas, cabras, carneiros, lebres, javalis, búfalos, texugos, antílopes, gazelas, eqüinos, cervos, gambás, porcos selvagens, ratos, roedores selvagens, lontras, bisões, esquilos, doninhas, corvos, toupeiras, minks (martas), furões e focas 2, 19, 24, 25, 32, 57, 59, 63, 64, 65, 87 89, 91, 92, 105, 115, 125, 132, 135, 137 , 148, 160, 163, 173, 178, 181, 192, 201, 208, 216, 228, 236, 237, 248, 259, 261, 263, 265, 269.

Anteriormente dava-se pouca importância a essas fontes de infecção, mas a gradual eliminação da tuberculose nos bovinos tem ressaltado o perigo representado por esses reservatórios, pois animais selvagens infectados são responsáveis atualmente por casos esporádicos de tuberculose bovina ${ }^{196}$. 
A tuberculose foi reconhecida como uma séria doença clínica em mamíferos selvagens cativos, há mais de um século ${ }^{199,280}$. Com o passar dos anos, houve um crescente interesse em relação à tuberculose em espécies cativas exóticas, devido aos informes da doença em animais de zoológicos e de outras instituições como centros de primatas, colônias animais em universidades e parques animais e de caça; locais que favorecem a propagação do M.bovis ${ }^{137,196,199,260,280}$. Animais selvagens cativos, freqüentemente, não são submetidos às leis governamentais de teste para tuberculose, e podem servir como reservatórios da infecção por M.bovis para animais domésticos e principalmente para o bovino e seres humanos, especialmente os trabalhadores rurais $137,194,196,256,260,265$.

Além disso, com o aumento na incidência de tuberculose humana por M.tuberculosis, em áreas urbanas com grandes populações de imigrantes e em grupos de risco para o desenvolvimento de AIDS, poderia haver um aumento correspondente na tuberculose em animais domésticos em um futuro próximo ${ }^{89,159,194 .}$

Por isso, a importância dessas ocorrências de tuberculose foi acentuada pelo risco que representam para a saúde pública, pelas perdas econômicas e a dificuldade de reposição de certos animais exóticos $\operatorname{raros}^{260,261}$.

Em um estudo realizado nos Estados Unidos, no período de 1 de julho de 1971 a 30 de junho de 1976, baseado em exames micobacteriológicos de 474 espécimes de animais exóticos suspeitos de terem tuberculose, foram encontrados 263 animais comprovadamente doentes. Do total de 263 animais tuberculosos, 114 $(43,3 \%)$ isolamentos de micobactérias foram em animais de zoológicos; 59 (22,4\%) em animais de centros de primatas; 48 (18,3\%) em animais de parques animais e de caça e $42(16,0 \%)$ em colônias animais de universidades, sendo que o M.bovis foi isolado em $74(28,1 \%)$ desses animais, em 18 Estados americanos ${ }^{260}$.

Dos 114 animais de zoológicos doentes, 19 (16,7\%) estavam infectados pelo M.bovis em 7 zoológicos de 6 Estados diferentes. O M.bovis foi isolado de 5 animais $(8,5 \%)$ de um total de 59, em 2 centros de primatas em 2 Estados americanos. Esta micobactéria também foi responsável por 56,3\% (27 animais em 48) dos isolamentos em animais de 7 parques, em outros 7 Estados, e por 54,8\% (23 animais em 42) dos 
isolamentos em animais de 8 colônias animais, diagnosticados nos laboratórios das universidades, em 6 Estados distintos ${ }^{260}$.

No período de 1983 a 1992, na França, de um total de 282 isolamentos de micobactérias em animais domésticos e selvagens, 56 (19,9\%) cepas eram M.bovis. Do total de 56 cepas de M.bovis, 24 (42,9\%) ocorreram em caprinos, 15 (26,8\%) em animais selvagens, $5(8,9 \%)$ em gatos, $3(5,3 \%)$ em suínos, 2 (3,6\%) em cachorros, 1 $(1,8 \%)$ em ovinos, $1(1,8 \%)$ em cavalos, $1(1,8 \%)$ em animais de laboratório e 4 $(7,1 \%)$ em animais não identificados ${ }^{264}$.

No Brasil, são raras as pesquisas existentes sobre o papel dos reservatórios animais na transmissão da tuberculose humana e bovina, especialmente os selvagens mantidos em cativeiros, uma vez que o teste da tuberculina não é realizado rotineiramente nos zoológicos brasileiros, a não ser em situações especiais. Até 1983, não havia estudos sobre animais silvestres reservatórios no Brasil ${ }^{99}$.

Devido à importância que a tuberculose voltou a assumir na atualidade e uma vez que os animais mantidos em cativeiros para exposição pública estão potencialmente sujeitos à doença, através de alimentos contaminados que podem ser lançados pelos visitantes aos recintos, Diniz e col. (1994) ${ }^{99}$ realizaram o teste tuberculínico em 105 mamíferos silvestres mantidos em cativeiro no zoológico de São Paulo, em estado de higidez, com alimentação apropriada e alojamento adequado para cada espécie e, no mínimo, há 2 anos em cativeiro ${ }^{99}$.

O PPD foi aplicado em 58 primatas (42 macacos-prego e 16 sagüis) e 47 carnívoros (37 quatis e 10 felídeos constituídos por 2 onças, 1 jaguatirica e 7 gatos), sendo que $6(5,7 \%)$ animais foram tuberculina-positivos. Os animais positivos à tuberculina foram 1 felino (10,0\%), 3 quatis $(8,1 \%)$ e 2 macacos-prego (4,8\%). Todos os animais foram sacrificados. Os autores recomendaram o desenvolvimento de programas de saúde tanto para animais silvestres mantidos em cativeiros, quanto para seus tratadores e profissionais técnicos que lidam diretamente com coleções desses vertebrados ${ }^{99}$.

Entre os principais reservatórios animais da infecção por M.bovis, encontram- 
se:

\section{a) TEXUGOS}

Na Europa, verificou-se que entre a população de animais selvagens, o texugo é o mais importante reservatório da infecção por M.bovis, principalmente na Inglaterra e País de Gales, fazendo a tuberculose bovina ressurgir após a sua erradicação em certas áreas 25, 31, 47, 68, 92, 123, 124, 125, 148, 167, 173, 196, 201, 228, 261, 279, 297. Apesar de outros animais selvagens se apresentarem infectados por M.bovis, nenhum possui uma prevalência de infecção maior que os texugos ${ }^{64}$. Embora seja difícil diagnosticar a infecção por M.bovis em texugos, evidências sugerem que cerca de $22 \%$ de algumas populações de texugos do sudoeste da Inglaterra, encontram-se infectadas ${ }^{123}$.

O texugo europeu da espécie Meles meles é amplamente distribuído em toda a Europa, mas existem poucos registros de infecção por M.bovis em texugos fora da Grã-Bretanha (sudoeste da Inglaterra) e República da Irlanda (Irlanda do Norte $)^{58,167,173,196,199,208,210,216,297}$. A doença nos texugos tem sido intensamente estudada nesses 2 países, e evidências demonstraram que a prevalência da infecção na população de texugos apresentou uma flutuação de 2 a 12\% em uma série de $\operatorname{anos}^{199}$.

Apesar da tuberculose em texugos, causada pelo M.bovis, ter sido primeiramente registrada em Basle, na Suíça em 1956, provavelmente adquirida de cervos doentes da raça "roe", onde a doença foi diagnosticada post mortem em 5 $(18,5 \%)$ de 27 texugos e em $11(1,2 \%)$ de 892 cervos dessa raça, a epidemiologia da doença nestes animais tem sido estudada apenas desde 1971, quando a carcaça de um texugo infectado foi encontrada em uma fazenda em Gloucestershire, Inglaterra, decorrente de investigações realizadas pelo MAFF, em razão de surtos inexplicáveis de tuberculose bovina no gado 47, 58, 68, 125, 146, 167, 180, 199, 203, 210, 216, 265, 278, 285, 286. Acima de 30 texugos foram pegos dentro dos limites dessa fazenda e 12, foram encontrados tuberculosos ${ }^{26}$. 
Como os cervos encontrados na região de Basle estavam infectados por M.bovis, sugeriu-se na época, que a ingestão de carcaças de cervos, havia sido a origem da infecção no texugo. Houve também a menção de um possível envolvimento com cabras, mas nenhuma ligação com tuberculose no bovino foi sugerida. Entretanto, estudos realizados em Gloucestershire levantaram a suspeita de que a tuberculose se instalou na população de texugos antes de 1960, quando lesões pulmonares no gado eram comuns ${ }^{203}$.

Investigações locais subsequentes na população de texugos, dentro e ao redor das fazendas, onde bovinos reatores à tuberculina haviam sido encontrados, revelaram prevalências de infecção por M.bovis superiores a 35\%, em texugos. Estes estudos envolveram a captura, exames bacteriológicos e post mortem das carcaças, revelando que as cepas de M.bovis dos texugos e bovinos eram bacteriologicamente indistinguíveis ${ }^{286}$.

Entre 1971 e 1983, 13\% das 6.000 carcaças de texugos examinadas pelo Ministério da Agricultura, na Inglaterra, eram tuberculosas ${ }^{125}$. Gloucestershire possui uma das maiores populações de texugos da Grã-Bretanha ${ }^{203}$.

Em uma revisão dos dados acumulados na distribuição e prevalência de tuberculose na população de texugos na Grã-Bretanha, durante o período de 1972 a 1987, de um total de 15.064 texugos examinados, 588 (3,9\%) estavam positivos para M.bovis, em 16 dos 61 municípios britânicos, com maior prevalência na região sudoeste. Muitos desses texugos haviam sido mortos nas rodovias. A prevalência da infecção por M.bovis nos texugos desses municípios, oscilou de $0,4 \%$ em Somerset a $11,5 \%$ em Gloucestershire ${ }^{58}$.

A falta de evidência de infecção por M.bovis nestes animais, na Escócia e certos municípios no sul da Inglaterra como Hampshire e Kent, pode ser devido ao fato de que um número insuficiente de carcaças de texugos foi examinada nessas áreas. Apenas 31 texugos foram examinados em toda a Escócia durante o período de 16 anos, acima citado, enquanto mais de 15.000 foram examinados no resto da GrãBretanha $^{58}$. 
Em alguns municípios, a presença da infecção por M.bovis em texugos não tem sido associada com tuberculose no bovino, o que indica que a infecção pode ser mantida na população de texugos na ausência de outra fonte de M.bovis ${ }^{210}$.

Durante as operações de controle de texugos realizadas no sudoeste da Inglaterra, no período entre 1985 e 1991, 15,4\% dos texugos mortos estavam infectados pelo M.bovis, comparados com 5,7\% de uma amostra de texugos mortos em rodovias, na mesma região e no mesmo período. Em 1992, a média de prevalência de tuberculose nos texugos mortos durante as operações de controle era de $20 \%$, comparada com $10 \%$ nos animais mortos nas rodovias ${ }^{279}$. Em 1993, foram encontrados texugos infectados por M.bovis em 22 dos 61 municípios da GrãBretanha $^{63}$. Até 1996, existiam 23 municípios que possuíam texugos infectados ${ }^{64}$.

A infecção por M.bovis em texugos, foi primeiramente registrada na República da Irlanda em $1975^{100,210,216}$. A tuberculose por M.bovis nesses animais, foi identificada em 26 municípios na República da Irlanda durante a década de 80 , e hoje, a doença é endêmica na população nacional de texugos ${ }^{58,100,199,216}$. O M.bovis foi isolado de cerca de $10 \%$ de 450 texugos examinados na Irlanda do Norte no período de 1977 a março de $1986^{216}$.

Em um estudo realizado, no período de 1985 a 1988, em 22 municípios da Irlanda, dos 2.633 texugos submetidos ao exame post mortem, entre $4,8 \%$ e $37,1 \%$ dos animais tinham lesões tuberculosas. Este estudo não forneceu a verdadeira estimativa da prevalência, uma vez que muitos casos de infecção sem lesões visíveis podem ocorrer, mas indicou que o M.bovis estava presente em 21 dos municípios estudados $^{210}$.

Um total de 3.909 texugos foi submetido ao exame post mortem nos Laboratórios Veterinários Regionais da Irlanda, entre 1980 e 1989, e 664 (17\%) apresentaram evidências de infecção por M.bovis, sendo que a grande maioria possuía grosseiras lesões tuberculosas. A tuberculose é primariamente uma doença respiratória em texugos, e isso se reflete no fato de que $60 \%$ das lesões foram encontradas nos pulmões e/ou linfonodos do trato respiratório no tórax e cabeça. Durante um período de 4 anos, de 1989-1992, 100 (12,9\%) das 778 carcaças de 
texugos submetidas ao exame laboratorial na Irlanda, tinham grossas lesões tuberculosas. Dos 100 texugos com lesões, 49 (49,0\%) tinham lesões nos pulmões e/ou linfonodos associados e entre os 51 (51,0\%) restantes, com lesões extrapulmonares, $22(43,1 \%)$ tinham lesões nos rins ${ }^{100,216}$.

No Athlone Regional Veterinary Laboratory na República da Irlanda, 178 (10\%) das 1.776 carcaças de texugos sujeitas ao exame post mortem em um período de 2 anos (1991-1992), estavam tuberculosas ${ }^{216}$.

Os texugos vivem em túneis subterrâneos, denominados "setts", e formam grupos sociais de, aproximadamente, 6 animais adultos mais os filhotes ${ }^{149}$. Em 1993, dados de uma tentativa de extrapolação para avaliar a população de texugos em toda a ilha, indicou que usando um tamanho médio do grupo social de 5.0 animais, havia cerca de 50.000 grupos sociais presentes, consistindo em cerca de 250.000 texugos adultos na República da Irlanda ${ }^{149,216}$. Este número foi relativamente maior que a população de texugos na Grã-Bretanha que consistia na época, de cerca de 43.000 grupos sociais, ou aproximadamente, 215.000 texugos adultos com uma produção anual em torno de 105.000 filhotes; mas a população estava largamente concentrada nas regiões sul e sudoeste, em uma área de terra proporcionalmente similar $58,149,216$. A partir de 1994, o total da população adulta de texugos na Irlanda foi declarado em 230.000, sendo 30.000 texugos na Irlanda do Norte e 200.000 na República da Irlanda, e em 250.000 na Grã-Bretanha ${ }^{149,210,216 .}$

As maiores densidades de texugos foram notadas na Irlanda do Norte, mas as maiores variações nas densidades de texugos foram registradas na República da Irlanda. Na Irlanda, muitos setts de texugos estão situados nas plantações que formam cercas vivas junto aos pastos, enquanto na Grã-Bretanha muitos setts estão situados nos bosques. Na Grã-Bretanha, apenas $15 \%$ dos grandes setts ativos estão situados nas plantações que formam cercas vivas junto aos pastos, 50\% nos bosques e florestas e 7\% nos arbustos. Na Irlanda, estimou-se que cerca de $60 \%$ dos setts de texugos estão localizados junto aos pastos, $19 \%$ nos bosques, e $21 \% \mathrm{em}$ $\operatorname{arbustos}^{100,149,216}$. Isto significa que os texugos na Irlanda vivem e se alimentam em íntimo contato com o bovino que, por sua vez, adquirem fácil acesso aos setts e 
latrinas dos texugos ${ }^{100}$.

Embora não exista esse animal no Brasil, a luta que a Grã-Bretanha e a República da Irlanda vêm empreendendo no combate aos texugos, é um exemplo para futuros programas de controle da tuberculose por M.bovis em outras populações de animais selvagens em nosso país, que porventura venham a ser infectadas por essa micobactéria.

\section{b) GAMBÁS}

Na Nova Zelândia, existe um marsupial que também perpetua o M.bovis no meio ambiente, reinfectando o bovino, além de gatos, porcos selvagens e cervos $^{25,92,105,125,142,149,160,173,178,196,199,201,228,259,269 .}$

Como a incidência da doença no bovino era muito alta na Nova Zelândia, principalmente nas regiões que formavam divisas com florestas e bosques, a busca por um reservatório da doença entre animais selvagens, foi iniciada em 1968. Apesar de a tuberculose ter sido encontrada em muitos animais, incluindo gatos, cervos, furões, cabras, porcos-espinho, coelhos e carneiros, o gambá foi mais freqüentemente afetado, com uma incidência de 3 a $40 \%$ dependendo da região. Os animais tuberculosos tinham uma doença disseminada progressiva e, freqüentemente, apresentavam muitos abcessos purulentos na pele, sendo uma fonte potencial de infecção para qualquer outro animal susceptível ${ }^{65,68}$.

O gambá australiano da raça "brush-tailed” e espécie Trichosurus vulpecula, proveniente da Austrália, é um reservatório endêmico da infecção por M.bovis na Nova Zelândia 24, 47, 61, 68, 69, 70, 125, 149, 151, 173, 178, 180, 199, 208, 216, 228, 269, 297 . Como a tuberculose parece não ocorrer entre os gambás australianos, acredita-se que estes animais adquiriram a doença de bovinos ou animais selvagens infectados, após sua chegada na Nova Zelândia 69, 70, 125, 151, 173, 269 . O primeiro gambá com lesões tuberculosas foi identificado na Nova Zelândia em 1967, após sua captura em uma armadilha em uma fazenda, na área de Westport, com persistente problema de 
tuberculose no gado $105,149,199,216$.

Os gambás são considerados como pragas pelo efeito devastador que exercem na produção agrícola, destruindo plantações e colheitas e também por serem uma potencial fonte de infecção do M.bovis, para animais domésticos e selvagens ${ }^{24,149,} 216$.

Estudos demonstraram que a infecção em gambás, está presente em várias áreas da Nova Zelândia e está aumentando sua distribuição geográfica ${ }^{199}$. A prevalência de casos, com lesões visíveis, nas áreas afetadas da Nova Zelândia é em média 5\%, com variações sazonais típicas de 2 a $10 \%{ }^{24,167,199,216 .}$.

A população de gambás da Nova Zelândia foi estimada em 1994, como sendo superior a 70 milhões, comparada com aproximadamente 230.000 texugos na Irlanda e 250.000 texugos na Grã-Bretanha $24,149,216,269$.

A tuberculose é endêmica em 6 áreas da Nova Zelândia onde, por causa de seu grande tamanho, cobertura do solo por enormes bosques nativos e a grande extensão de espécies infectadas, é tecnicamente impossível erradicar a tuberculose em vetores, nas populações de animais selvagens. Essas 6 áreas cobrem aproximadamente $22 \%$ da área terrestre da Nova Zelândia, mas contém aproximadamente $76 \%$ de bovinos infectados e $55 \%$ de rebanhos de cervos de criação infectados. A tuberculose bovina foi disseminada na população de gambás em ambas as regiões, norte e sul da ilha ${ }^{24,216,269}$.

No período de abril de 1973 a fevereiro de 1974, 1.467 gambás foram pegos em armadilhas ou envenenados. Todos foram autopsiados e $115(7,8 \%)$ estavam visivelmente infectados com M.bovis. Durante o mesmo período, um adicional de 334 gambás foi abatido por tiros em áreas periféricas, e a mesma proporção de animais, ou seja, $26(7,8 \%)$ estavam infectados ${ }^{65}$.

Em agosto de 1992 a infecção por M.bovis foi diagnosticada em 36 (53\%) de 68 gambás capturados em armadilhas, pertencentes a uma população de excepcionalmente baixa densidade, em arbustos que margeavam uma floresta em Westland, Nova Zelândia. A prevalência foi aproximadamente 7 vezes maior do que a registrada para a mesma população 12 anos antes, quando a densidade populacional 
era 5 vezes maior. Mais gambás machos (66\%) do que fêmeas (33\%) tinham lesões tuberculosas grosseiras visíveis. A aparentemente contínua distribuição da infecção ao longo de cerca de 5 quilômetros dos arbustos que margeavam a floresta, contrastou com os padrões previamente registrados de focos de infecção isolados espacialmente, centrados em pequenos terrenos cobertos de vegetais ${ }^{216}$.

A importância do gambá como reservatório endêmico da infecção por M.bovis na Nova Zelândia, despertou o interesse de Lagenegger e Langenegger $(1985)^{167}$ no Brasil, levando-os a realizar um estudo para esclarecer se o nosso gambá (Didelphis albiventris), que freqüentemente é encontrado no âmbito peridomiciliar, seria susceptível à infecção pelos agentes etiológicos da tuberculose ${ }^{167}$.

Foram capturados 31 gambás adultos, em propriedades rurais e em áreas residenciais de subúrbios de cidades e vilas de 4 municípios do Estado do Rio de Janeiro, de 1 município de Minas Gerais e de 1 município do Estado de São Paulo. Em algumas fazendas desses municípios em que os gambás foram capturados havia tuberculose no rebanho bovino, e em outras, a tuberculose já havia sido eliminada anteriormente, o que ensejou a provável exposição de gambás ao contágio natural da tuberculose bovina. No entanto, a necropsia dos 31 gambás, bem como o exame bacteriológico específico para o isolamento de micobactérias de fragmentos de órgãos e linfonodos, não revelaram lesões, nem a presença dos agentes da tuberculose ${ }^{167}$.

A infecção experimental de outros 12 gambás, mantidos em cativeiro, feita pelas vias oral e intramuscular, com altas doses infectantes de M.tuberculosis, M.bovis e M.avium, não permitiu reproduzir a doença, embora tenha sido possível estabelecer a infecção local, no ponto de inoculação. A julgar pela extensão da lesão local, o M.bovis pareceu ser um pouco mais agressivo do que o M.tuberculosis na infecção intramuscular. O M.avium não foi reisolado dos gambás contaminados por via oral e nem do ponto de inoculação dos animais infectados pela via intramuscular $^{167}$.

Inesperadamente, entretanto, foi possível isolar 50 culturas de micobactérias 
ambientais (MOTT), nos primeiros 31 animais capturados, possivelmente veiculadas com o alimento do meio exterior. Nos 12 gambás infectados experimentalmente, não foram isoladas essas micobactérias devido, provavelmente, às condições de cativeiro a que foram submetidos, pois eram alimentados apenas com ovos e frutas o que, certamente, evitava o contato com micobactérias ambientais ${ }^{167}$.

A ausência de casos naturais de tuberculose em gambás e a impossibilidade de reproduzir a doença experimentalmente permitiram aos autores concluírem que o gambá brasileiro é resistente à infecção natural da tuberculose ${ }^{167}$.

\section{c) CERVÍDEOS}

A tuberculose causada por M.bovis tem sido, há muito, reconhecida em cervos cativos e domésticos e está emergindo como a mais importante doença que afeta esses animais ${ }^{61,134,167,216,277}$. Animais infectados, em lugares como zoológicos e parques, são vistos como um risco para humanos e outros animais ${ }^{61,134,194,216}{ }^{\text {. A }}$ doença é esporadicamente encontrada em cervos selvagens e quando ocorre, geralmente, resulta da propagação da infecção em rebanhos de cervos domésticos e cativos ${ }^{61}$ 134, 199 . Em uma revisão de literatura de tuberculose em cervos, realizada em 1991, constatou-se que a prevalência da doença em cervos selvagens era menor que $5 \%$ 61, 216, 265 .

O advento da criação de cervos em fazendas destinadas à pecuária amplificou a incidência da tuberculose por M.bovis ${ }^{134,148,259}$.

A epidemiologia da infecção do M.bovis em cervos, não tem sido completamente investigada como no bovino e alguns aspectos da doença são ainda pouco compreendidos. Entretanto, acredita-se que os cervos domesticados podem ser mais susceptíveis à infecção que os bovinos, uma vez que, sob certas circunstâncias, extensas lesões podem desenvolver-se rapidamente, aumentando a probabilidade da transmissão em um rebanho ${ }^{61,199}$.

Nos últimos 60 anos, casos de infecção por M.bovis em cervídeos selvagens, 
foram relatados nos Estados Unidos, Canadá, Nova Zelândia, Suíça, Hungria, Irlanda, Grã-Bretanha e em alguns outros países ${ }^{61,216,265}$.

Em anos mais recentes, a tuberculose em cervos causada pelo M.bovis, tornou-se uma doença de importância, tanto econômica como de saúde pública, para a criação e indústria de cervos em muitos países, particularmente na Nova Zelândia, Reino Unido e Dinamarca, porque são animais muito susceptíveis à infecção tuberculosa e um risco para outros animais e humanos ${ }^{61,179,216}$. Estes 3 países têm controle nacional ou esquemas de erradicação para a tuberculose por M.bovis em $\operatorname{cervos}^{216}$.

A Nova Zelândia foi o primeiro país do mundo a desenvolver o conceito de criação de cervos para a produção de carne e veludo e essa prática tornou-se comum no mundo todo. Cada país envolvido com cervos domésticos tem sofrido esporádicos, porém sérios, surtos epidêmicos de tuberculose por M.bovis 40, 61, 134, 216 . A atividade iniciou-se em 1955, com o confinamento de 9 cervos da raça "red", em uma propriedade privada a cerca de 40 milhas ao norte de Wellington ${ }^{216,269}$.

No sul da Nova Zelândia, o M.bovis foi isolado pela primeira vez em um cervo selvagem da raça "red" e espécie Cervus elaphus caçado em $1970^{61,177,208,216,259}$. Em 1976, ocorreu o primeiro caso de M.bovis no norte da ilha, em um cervo selvagem ${ }^{177,216}$. Em 1978, o M.bovis foi isolado pela primeira vez em um cervo de criação, também da raça "red", em uma propriedade no sul da ilha ${ }^{61,177,259,265,269}$.

A tuberculose é uma das mais importantes doenças bacterianas que afetam cervos na Nova Zelândia. Esta alegação é baseada na prevalência de infecção, perdas de produção devidas à doença clínica e problemas regulatórios e de comercialização, associados à essa zoonose ${ }^{177,216}$.

Em 1980, 62 (0,1\%) isolamentos de M.bovis foram obtidos de um total de 64.000 cervos selvagens processados em fábricas de embalagem de carne ${ }^{216}$. Em 1981, outro caso de infecção por M.bovis foi registrado em um cervo de criação na Nova Zelândia ${ }^{177,216}$. O M.bovis foi isolado de 504 cervos, durante o período de 
1970 a 1983, na Nova Zelândia ${ }^{177}$.

A tuberculose dos cervídeos tem emergido como um problema significativo em cervos de criação e em 1983, o M.bovis foi encontrado em 40 propriedades diferentes na Nova Zelândia ${ }^{177}$.

Uma grande proporção de cervos selvagens capturados ou mortos por tiros foram encontrados infectados com M.bovis em 1985, sugerindo que na Nova Zelândia, onde cervos eram capturados vivos em muitas partes do país e então comercializados para fins de procriação, os animais infectados provavelmente contribuíram para a introdução da infecção em áreas consideradas livres de tuberculose. Por isso, um esquema de erradicação voluntária da tuberculose em cervos foi introduzido neste mesmo ano ${ }^{65,199}$.

Em 1985, a prevalência nacional da infecção por M.bovis em cervos de criação na Nova Zelândia, foi estimada em 0,6\% e em 1989, 0,4\% ${ }^{65}{ }^{186}$. Entretanto, a prevalência da infecção em rebanhos ou grupos particulares, poderia ser muito maior ${ }^{186}$. Foi estimado que no meio do ano de 1989 , existiam mais de 400.000 fêmeas e 100.000 machos nas fazendas da Nova Zelândia. No final de 1991, 3,9\% dos rebanhos de cervos estavam sob controle e restrição de movimentos. Em 1994, estimou-se que havia 1,2 milhões de cervos de criação em 6.500 rebanhos, sendo que, aproximadamente, $85 \%$ eram da raça “red" e espécie Cervus elaphus ${ }^{216,269 .}$

No Reino Unido, a tuberculose por M.bovis foi inicialmente diagnosticada em 1985 em um cervo da raça "red", importado da Hungria ${ }^{41}$. Em um grupo de cervos da mesma raça, importados do leste europeu em 1988, 20 (39,2\%) dos 51 animais, foram confirmados como tuberculosos ${ }^{186}$.

Na Inglaterra o M.bovis foi isolado de um cervo da raça "axis" no Parque Whipsnade em 1964. Em 1984, 4 (3,0\%) de 131 cervos caçados no sudeste da Inglaterra, sendo 3 da raça "sika" e 1 da raça "roe", foram encontrados infectados com M.bovis. Casos de tuberculose bovina têm sido encontrados em cervos selvagens, em regiões da Inglaterra conhecidas por conterem texugos infectados. Durante os anos 1985 e 1986, 4 (4,9\%) de 81 cervos da raça "sika" e $1(2,9 \%)$ de 35 
da raça "roe", selecionados na vizinhança de 3 rebanhos de bovinos infectados por tuberculose em Dorset, foram encontrados infectados com M.bovis ${ }^{216}$.

Em 1986, a infecção por M.bovis foi confirmada em 8 cervos selvagens na Inglaterra, todos com lesões visíveis. Contudo, acreditou-se que era improvável que cervos selvagens pudessem oferecer um risco significante para o bovino. Em 1989, o número total de cervos de criação na Grã-Bretanha era de aproximadamente 40.000 animais, sendo que metade deles era de fêmeas prenhas, além de um número similar de cervos cativos em parques. Em 1993, 1 (5,9\%) cervo da raça "roe", pertencente a um grupo de 17 cervos selvagens caçados no sudeste da Inglaterra, tinha lesões tuberculosas confirmadas no exame post mortem ${ }^{216}$.

Na Dinamarca a grande maioria dos cervos de criação pertence à raça “fallow”. Em 1989, havia 540 fazendas de criação de cervos, com uma população total de, aproximadamente, 25.000 animais. O diagnóstico inicial da tuberculose por M.bovis foi realizado em 1988 e a doença encontrada, subseqüentemente, em pelo menos 7 fazendas. ${ }^{61,216,259}$.

Na Irlanda, em 1984, a infecção por M.bovis foi confirmada em 5 (3,8\%) de 130 cervos mortos por caçadores e em 1986, um caso de infecção por M.bovis ocorreu em um cervo da raça "fallow" e espécie Dama dama ${ }^{216}$.

Nos Estados Unidos, em 1934, 2 casos de tuberculose em cervos selvagens da raça "white-tailed" e espécie Odocoillus virginianus, foram relatados no Estado de Nova York. Esses animais foram caçados, respectivamente, nas regiões de Delaware e Broom, onde havia naquela época, alta incidência de tuberculose no gado. Foram confirmados 2 novos casos de infecção por M.bovis no estado de Nova York, em $1961^{216}$.

No período de 1971 a 1976, o M.bovis foi isolado em 74 animais cativos, sendo $13(17,6 \%)$ isolamentos em cervos e $1(1,4 \%)$ em alces ${ }^{260}$.

Em 1980, ocorreu um surto de infecção por M.bovis nos Estados Unidos e requereu a investigação de 9 rebanhos de alces em 7 Estados americanos e aplicação do teste tuberculínico em bisões e rebanhos de bovinos. A infecção espalhou-se para 
humanos e bisões em contato com os alces ${ }^{108,216}$.

No período de 1984 a 1993, nos Estados Unidos, foram confirmadas infecções por M.bovis em 14 rebanhos de cervídeos cativos, sendo que 3 desses rebanhos encontravam-se em Nova York, 4 em Montana, e 1 em cada um dos Estados de Colorado, Idaho, Indiana, Nebraska, Oklahoma, Texas e Wisconsin. Cervos estavam infectados em 7 Estados, alces em 5 e cervos e alces em 2. Cinco casos documentados de infecção entre espécies de bovinos e cervídeos ocorreram no período de 1991 e $1992^{216}$.

De 1991 a 1996, 31 rebanhos de cervídeos cativos estavam infectados por M.bovis nos Estados Unidos. Em 1995, havia um rebanho de cervídeos cativos infectados, em cada uma de 5 regiões americanas: Texas, Colorado, Missouri, Carolina do Norte e Montana ${ }^{176}$.

Em 1995, a infecção por M.bovis foi confirmada em um cervo da raça "whitetailed" na área de Alpena, Michigan, que é considerada o único foco de infecção na população de animais selvagens nos Estados Unidos, cuja prevalência da doença é alta o suficiente, para considerar essa raça de cervos presentes nessa área, um reservatório permanente de M.bovis ${ }^{176}$.

Apesar da infecção por M.bovis ter sido, raramente, constatada em cervídeos selvagens, em muitas áreas dos Estados Unidos as densidades de cervos e alces selvagens excederam as densidades observadas em outros países. A população de cervos da raça "white-tailed" nos Estados Unidos em 1991, foi estimada como sendo acima de 18,4 milhões, comparada com uma população de cerca de 300.000 a 500.000 no começo do século. Os cervos da raça "white-tailed" estavam concentrados em dois terços da região leste dos Estados Unidos, onde a sua densidade excedia 100 cervos por milha quadrada (39 cervos por quilômetro quadrado $^{216}$.

A população de alces, estimada em 1991, era de 714.000, com densidades excedendo 5 alces por milha quadrada ( 2 alces por quilômetro quadrado) em partes do Colorado, Idaho, Oregon, Washington e Wyoming ${ }^{216}$. 
Em 1995, existiam mais de 5 milhões de cervos da raça "mule" (Odocoileus hemionus), nos Estados Unidos, além de 18.000 proprietários privados de alces, e cerca de 30.000 cervos cativos, excluindo-se os da raça "white-tailed" ${ }^{216}$.

A infecção por M.bovis tem sido registrada em cervos de criação da raça "fallow", na Suécia. Em 1991, a doença foi identificada em um rebanho desta raça e espécie Dama dama, e nos 3 anos seguintes, em 9 outros rebanhos. Até 1991, durante 50 anos, não foram descobertos casos de tuberculose em animais selvagens e o último caso em bovinos havia ocorrido em 1978, quando um fazendeiro com tuberculose renal infectou seu gado $40,216,258$.

Em Ontario, Canadá, nos meses de outubro e novembro de 1991, foram encontrados 2 rebanhos de cervídeos infectados por M.bovis, sendo que o primeiro consistia de 311 cervos e alces, dos quais 71 (23\%) apresentaram lesões tuberculosas grosseiras no exame post mortem. O segundo rebanho consistia de 91 cervos, dos quais 16 (18\%) foram condenados. Em 1994, existiam cerca de 263 rebanhos de cervos e alces de criação em Ontario e o contato com esses rebanhos representou um risco ocupacional para o homem, como no surto de tuberculose por M.bovis ocorrido em 1990, em Alberta ${ }^{179}$.

Em 1992, foi relatado que cerca de 50 cabeças de gado leiteiro, reatores a tuberculina, foram sacrificados a cada ano no Japão e apesar de surtos de tuberculose em gado de corte não terem sido registrados desde 1963, ocorreram surtos esporádicos em animais mantidos em jardins zoológicos. O M.bovis foi isolado de um cervo Japonês da raça "shika" e espécie Cervus nippon, morto em um zoológico e este foi o primeiro caso de tuberculose em cervos, devido a este agente, no Japão. Realizou-se então uma inspeção em todo o rebanho, constituído de 17 cervos, e no qual 3 desenvolveram sintomas respiratórios em 1984. Após o teste tuberculínico, todos eram reatores ou suspeitos, e por isso, foram sacrificados. No exame post mortem, 6 cervos apresentaram lesões tuberculosas nos linfonodos retrofaringeais, sendo que um deles tinha avançada calcificação no pulmão ${ }^{152}$.

Em 1993, o M.bovis foi isolado de 5 cervos da raça "red", caçados ou capturados em um período de 6 anos, em diversas áreas geográficas da Hungria ${ }^{216}$. 
No Brasil, a prevalência da tuberculose por M.bovis em cervídeos é praticamente desconhecida e considerada de pouca importância epidemiológica. Houve um registro de tuberculose em cervo-do-mangue (Blastocerus dichotomus) cativo em um zoológico de Americana, interior de São Paulo ${ }^{99}$.

\section{d) PRIMATAS NÃO HUMANOS}

Em macacos cativos, a incidência da tuberculose é extremamente alta e a taxa de mortalidade pode alcançar $10 \%$ ao ano. O macaco é igualmente susceptível à infecção por M.tuberculosis e M.bovis, e há poucas dúvidas de que o macaco em cativeiro é o mais susceptível de todos os animais à tuberculose ${ }^{137,173,216,261}$. A doença nesses animais, geralmente, é progressiva e generalizada e os surtos epidêmicos ocorrem principalmente em colônias de primatas. Até 1983, não havia registro de infecção por M.bovis em macacos selvagens ${ }^{173}$.

O diagnóstico da doença é feito através de exames bacteriológicos, imunológicos e radiológicos. Para a realização desses exames, torna-se necessária a administração de tranquilizantes ao animal. O exame bacteriológico é realizado no escarro, lavado gástrico ou fezes, nos quais o bacilo da tuberculose é eliminado ${ }^{96}$.

Francis, em 1958 declarou que 78\% das cepas isoladas de bacilo da tuberculose em macacos cativos, eram do tipo humano, às quais eles eram obviamente mais expostos ${ }^{216}$.

Gay (1955) ${ }^{122}$, descreveu um caso de tuberculose ocular em um macaco de 2 anos de idade, pertencente à uma colônia de primatas da Army Medical Service Graduate School em Washington, nos Estados Unidos, após a realização de exames clínicos completos nos animais, incluindo radiografias em todos eles. A autópsia desse animal revelou que além das lesões na cavidade orbital havia outras na traquéia, nos linfonodos bronquiais, nos pulmões, baço e fígado, caracterizando uma tuberculose miliar. Foram observados bacilos álcool-ácido resistentes nas lesões, mas a micobactéria não foi isolada ${ }^{122}$. 
Em 1974, ocorreu um surto de infecção por M.bovis em macacos na região de Bufallo, no estado de Nova York. Todos os 10 macacos infectados apresentaram lesões pulmonares. Desses, 9 eram tuberculina-positivos e exibiam abscessos em vários órgãos na necropsia ${ }^{216}$.

O M.bovis foi isolado de 2 babuínos (Papio papio) fêmeas, tuberculinapositivas, que estavam em quarentena em um laboratório de Illinois. Esses 2 animais apresentaram lesões tuberculosas visíveis no fígado, baço, pulmão e linfonodos mediastínicos, na necropsia. A fonte de infecção não foi identificada, mas como a tuberculose é considerada extremamente rara ou inexistente em babuínos selvagens, suspeitou-se do transporte desses animais até o laboratório ${ }^{216}$.

Em um estudo realizado nos Estados Unidos, no período de 1971 a 1976, dos 99 isolamentos de micobactérias em primatas não humanos, $28(28,3 \%)$ eram M.bovis, sendo que 26 cepas foram obtidas de macacos e 2 de babuínos ${ }^{216,260}$.

Em 1988, ocorreu um surto de tuberculose em uma colônia de primatas de um laboratório americano, no qual $10(90,9 \%)$ dos 11 isolamentos eram M.bovis e 1 $(9,1 \%)$ M.tuberculosis ${ }^{216}$.

No Brasil, são poucos os relatos de tuberculose em primatas. Entretanto, em 1972 ocorreu um caso de tuberculose pulmonar em um chimpanzé (Pan troglodytes) macho, de 5 anos de idade, no zoológico de São Paulo, proveniente de um circo. O animal chegou ao zoológico em março deste mesmo ano e apresentava letargia, anorexia, desidratação, além de um pelo ralo, seco e sem brilho. O chimpanzé era tuberculina-positivo e por isso foi mantido em uma área de quarentena. O diagnóstico da tuberculose baseou-se na presença de bacilos álcool-ácido resistentes no fluido pleural e nos resultados dos raios-X. Não foi realizada a identificação da micobactéria. Por ser um animal de grande valor zoonótico, o chimpanzé foi tratado com isoniazida e rifampicina ${ }^{97}$.

Segundo os autores, a presença de tuberculose em um animal de circo, enfatiza a importância da tuberculinização periódica, uma vez que a proximidade dos animais com o público constitui um importante elo na cadeia epidemiológica da 
doença 97 .

Neste mesmo ano, ocorreu a morte de 2 macacos com tuberculose devida ao complexo M.avium ${ }^{83}$, e Diniz e col. (1993) ${ }^{98}$, relataram um surto de tuberculose por M.tuberculosis em 11 macacos-prego (Cebus sp.), também pertencentes à Fundação Parque Zoológico de São Paulo ${ }^{98}$.

\section{e) SUÍNOS}

O suíno, no que se refere aos 3 tipos clássicos de micobactérias (M.tuberculosis, M.bovis e M.avium), pode ser considerado uma vítima, pois está demonstrado que a infecção destes animais pelo M.tuberculosis ocorre quando são alimentados com restos de comida de hospitais, sanatórios e restaurantes, não convenientemente tratadas $48,135,245,261,272$. A infecção pelo M.bovis estabelece-se quando são alimentados com leite contaminado ou sub-produtos da indústria de laticínios, originários de rebanhos com tuberculose, além de restos animais em abatedouros e açougues, de excreções de bovinos tuberculosos ou por material fecal nos currais. E a infecção pelo M.avium ocorre quando são alimentados com vísceras e outros subprodutos provenientes de granjas e de matadouros avícolas, em áreas onde existe tuberculose $48,55,173,199,261,272$.

Além das micobactérias como agentes etiológicos da tuberculose, outra bactéria, também encontrada no solo, é capaz de infectar suínos. Essa bactéria, denominada Rhodococcus equi (anteriormente conhecida como Corynebacterium equi), provoca lesões ganglionares que são muitas vezes indistingüíveis das lesões tuberculosas. Esta bactéria foi isolada de gânglios linfáticos de suínos, com ou sem lesões tuberculosas, em vários países. As lesões causadas pelo R.equi, localizam-se principalmente nos gânglios linfáticos da cabeça ${ }^{215}$.

Em 1914, Eastwood e Griffith, na Inglaterra, investigaram 5 casos de tuberculose generalizada e 73 casos de tuberculose, aparentemente localizada, em suínos. Desses 78 casos, 49 (62,8\%) foram causados por M.bovis, 26 (33,3\%) por 
M.avium e 1 (1,3\%) por M.tuberculosis. Os 2 (2,6\%) casos remanescentes, apresentavam infecção mista ${ }^{135}$. Foi registrado que no período de 1952 a 1968, 80\% de 318 isolamentos de rotina do bacilo da tuberculose em porcos, na Grã-Bretanha, eram M.avium e $20 \%$, M.bovis ${ }^{216}$.

Em 1992, a tuberculose devida ao M.bovis foi confirmada em 9 (20\%) de 44 porcos selvagens e reprodutores, caçados na Hungria, no período de 1985 a $1991^{216}$.

Níveis de doença em porcos, usualmente, refletem aqueles na população bovina local, e altos níveis de doença no gado pode resultar em prevalências superiores a $20 \%$, nos porcos ${ }^{199,216}$. Programas para a erradicação da tuberculose bovina ajudam diretamente na redução das taxas de infecção entre suínos ${ }^{181,216}$. Nos Estados Unidos, em 1924, lesões tuberculosas foram encontradas em 15,2\% dos porcos mortos em açougues, enquanto em 1970 elas foram encontradas em apenas $1,1 \%{ }^{216}$.

No período de 1986 a 1989, estudos realizados em 13 países da América Latina e Caribe, demonstraram uma prevalência de tuberculose por M.bovis em suínos abatidos que variou de 0 a 3,2\%. A tuberculose suína exercia o segundo maior impacto econômico na Argentina, onde a prevalência da doença nesses animais $(3,2 \%)$ era tão alta quanto nos bovinos. No Brasil, a prevalência $(0,1 \%)$ foi bem menor que na Argentina. A alimentação de suínos com produtos derivados do leite de vacas tuberculosas foi apontada como a principal fonte de infecção. O controle da doença no gado contribuiu para o declínio da doença no suíno, entretanto, condenações continuavam a ocorrer devido a outras infecções micobacterianas, principalmente pelo M.avium ${ }^{156}$.

Langenegger e col. (1972) ${ }^{165}$, relataram que a inspeção macroscópica de gânglios linfáticos cervicais de 2.000 suínos de abate, com mais de 1 ano de idade e oriundos do interior do Estado do Paraná, revelou 62 linfonodos com focos necróticos, semelhantes à lesão tuberculosa. $\mathrm{O}$ exame bacteriológico permitiu o isolamento de 41 cepas de micobactérias, sendo 3 cepas (7,3\%) de M.bovis, 31 $(75,6 \%)$ do grupo M.avium-intracellulare (complexo MAC) e $7(17,1 \%)$ de outras espécies de micobactérias ${ }^{165}$. 
Correa e Correa (1972) ${ }^{79}$ isolaram 9 cepas de micobactérias em suínos, provenientes de um matadouro da Grande São Paulo, sendo 3 de M.bovis, 3 de M.tuberculosis e 3 de M.avium. Algumas dessas cepas eram resistentes à antibióticos de $1^{\text {a }}$ linha ${ }^{79}$.

Passos e col. (1989) ${ }^{222}$ realizaram uma investigação epidemiológica sobre as zoonoses de maior constatação em suínos brasileiros, abatidos sob Inspeção Federal, em matadouros-frigoríficos localizados no Estado de São Paulo, no período de 1982 a 1984. Foram utilizadas as informações relativas a 194.361 suínos, procedentes de 306 municípios pertencentes a 8 Estados brasileiros, sendo 14 do Estado de Goiás, 3 do Mato Grosso, 5 do Mato Grosso do Sul, 35 de Minas Gerais, 62 do Paraná, 6 do Rio Grande do Sul, 13 de Santa Catarina e 168 de São Paulo ${ }^{222}$.

A tuberculose foi detectada em animais procedentes de 128 municípios de 7 Estados brasileiros, exceto o de Mato Grosso, com prevalências que variaram de 0,05\% para o Estado de Santa Catarina a 1,62\% para o Estado de Goiás, com um valor médio de $0,65 \%{ }^{222}$.

Os autores concluíram que essas informações poderiam fornecer valiosos subsídios, na escolha de prioridades para a adoção de medidas sanitárias, aos órgãos responsáveis pela Saúde Animal e Saúde Pública ${ }^{222}$.

Entre as micobactérias que infectam os suínos, as pertencentes ao grupo MAIS (M.avium, M.intracellulare e M.scrofulaceum) têm predominado no Brasil e em outros países, causando linfadenites tuberculóides no animal, sendo também freqüentemente isoladas no solo, em águas poluídas com resíduos industriais e domésticos, e em pacientes humanos com tuberculose pulmonar ${ }^{21,215}$.

As linfadenites tuberculóides dos suínos são destituídas de sintomatologia clínica, mas a sua ocorrência é extremamente indesejável, pois interfere com os resultados dos testes imunológicos, determina prejuízos econômicos elevados devido ao tipo de destino a ser dado às carcaças e oferece risco à saúde pública, particularmente, em indivíduos imunocomprometidos ${ }^{21}$.

No período de 1993 a 1994, de 60 carcaças de suínos abatidos no Estado de 
São Paulo, 30 apresentavam lesões tuberculóide macroscópicas; sendo que em 14 dessas carcaças com lesões, houve o isolamento do complexo MAIS nos linfonodos mesentéricos ${ }^{21}$.

\section{f) BÚFALOS}

A criação de búfalos, em muitas partes do mundo, tem se expandido na busca de uma nova opção para a produção de carne e leite, sobretudo nos países em desenvolvimento. Os búfalos são animais rústicos, com boa adaptação aos mais diversos tipos de clima e solo, suportam grandes variações de temperatura e adaptamse a terrenos de topografia alta ou baixa, inclusive em áreas alagadiças e mostram excelente desempenho produtivo e reprodutivo $28,240,241,242$. Por isso, uma falsa idéia de resistência à doenças foi imputada à espécie. Entretanto, doenças crônicas como a tuberculose assumem uma grande importância, devido à longevidade dos bubalinos, que podem atingir até 20 anos de vida produtiva ${ }^{241}$. Os mesmos preceitos sobre diagnóstico e controle da tuberculose de bovinos, têm sido empiricamente extrapolados para os búfalos ${ }^{240}$.

Acredita-se que haja no mundo de 150 a 175 milhões de búfalos, e o crescimento anual da população bubalina deve exceder a taxa de 10\%, principalmente nas Américas, contra uma taxa de aproximadamente 5\% para os bovinos $^{242}$.

Como nos bovinos, a via respiratória é a mais importante rota de transmissão da infecção por M.bovis em búfalos selvagens, sendo que na grande proporção dos casos ocorre também um único ou predominante envolvimento dos órgãos torácicos ${ }^{186,199,228 .}$.

Foi registrado no Egito, que o bovino e búfalo domésticos estavam infectados com M.bovis. Em 1989, 46 (0,05\%) das 96.219 cabeças de gado e 90 (0,16\%) dos 56.922 búfalos testados com tuberculina, foram classificados como reatores. Em abatedouros, os achados post mortem indicaram que a tuberculose em búfalos é, quase exclusivamente, uma doença respiratória ${ }^{216}$. 
A infecção por M.bovis em búfalos africanos de vida livre, da raça "cape" e espécie Syncerus caffer, ocorreu pela primeira vez em 1963, quando $8(68,5 \%)$ casos de tuberculose foram descritos entre 13 búfalos dessa espécie, mortos em um parque de caça em Uganda, África. Em 1982, a ocorrência de tuberculose bovina em búfalos selvagens da raça "cape” no Ruwenzori National Park, Uganda, foi registrada. Lesões tuberculosas foram encontradas em 5 (10\%) dos 52 búfalos de uma amostra ao acaso e em $24(38 \%)$ de 64 animais que foram selecionados por causa de suas más condições. Muitos casos aparentavam ter sido infectados por transmissão respiratória, uma vez que não tinham lesões que pudessem ser atribuídas à infecção digestiva $^{199,216}$.

Em 1992, a tuberculose foi muito difundida nessa raça de búfalos na parte sul do Kruger National Park, em Uganda. A prevalência de manadas infectadas por M.bovis, em 1991 e 1992, foi de 25\%. A tuberculose devida ao M.bovis em búfalos, foi diagnosticada neste parque em 1991, onde de um total de 32 rebanhos, 13 $(40,6 \%)$ estavam tuberculosos ${ }^{216,295}$.

Em 1993, a prevalência da doença em manadas de búfalos infectados variou de 3 a $33 \%$. Quarenta e quatro países da África reconheceram, oficialmente, a presença de tuberculose pelo M.bovis em sua população animal ${ }^{295}$.

A tuberculose bovina é endêmica, porém, com baixas prevalências, em populações de búfalos selvagens no Território Norte Australiano. No período de 1966 a 1974, a prevalência de tuberculose em búfalos da raça "water", era de 8\%. Em 1979, lesões tuberculosas foram encontradas em 193 (1,7\%) dos 11.322 búfalos examinados durante inspeções post mortem de rotina em 2 abatedouros. Constatou-se que, $97 \%$ das infecções por M.bovis em búfalos selvagens no norte da Austrália foi contraída pela via respiratória e ocorreu, com mais frequência, entre grupos familiares, porque o íntimo contato com o bovino era raro ${ }^{199,216,253}$.

Exames post mortem em animais tuberculosos de 4 abatedouros de búfalos, na Austrália, mostraram que 42,0\% dos animais apresentavam lesões restritas aos linfonodos pulmonares, e apenas 3,1\% tinham lesões nos linfonodos mesentéricos. As lesões estavam restritas aos linfonodos da cabeça em 11,6\% dos animais e 43,3\% 
dos búfalos tinham doença generalizada ${ }^{199,216}$.

Em 1957, de um total de 40.201 búfalos testados na Índia, 13,8\% animais eram positivos à prova da tuberculina. Em 1959, Sane e colaboradores assinalaram a ocorrência de tuberculose no aparelho genital de uma fêmea de búfalo, abatida no matadouro de Bandra ${ }^{94,226}$, e Deshpande e col. (1966) ${ }^{94}$, descreveram um caso de tuberculose uterina em uma búfala, também abatida neste matadouro ${ }^{94}$.

Consta que a introdução do búfalo no Brasil, ocorreu no final do século passado, por volta de 1890, na Ilha de Marajó. Estima-se a existência de aproximadamente 2 milhões de animais pertencentes às raças Carabao, Murrah, Jafarabadi e Mediterrânea, no território brasileiro, concentrados principalmente nos Estados do Pará e de São Paulo $28,242$.

A carne de búfalo é comercializada e, frequentemente, consumida como carne de bovino, mas o leite de búfala encontra um mercado mais seleto, tanto para o leite in natura (considerado mais rico que o de bovino e com baixa taxa de colesterol) quanto para a produção de derivados, em especial o queijo do tipo "mozzarella",28,240,242.

Portugal e col. (1971) ${ }^{226}$, descreveram a ocorrência de tuberculose em um rebanho de búfalos (Bubalus bubalis var. bubalis-Linneus,1758) no Estado de São Paulo. O rebanho, constituído de 250 búfalos, apresentou 16 animais tuberculinapositivos. $\mathrm{O}$ abate de 1 desses animais, permitiu o isolamento do M.bovis em lesões caseosas de gânglios retrofaríngeos ${ }^{226}$.

Vale e col. (1978) ${ }^{271}$, descreveram um caso de tuberculose genital em uma búfala (Bubalus bubalis var. bubalis-Linneus,1758) em um matadouro da cidade de Belém, Pará. Neste animal, observou-se uma completa alteração do sistema genital no exame post mortem, com a presença de nódulos caseosos generalizados, além de lesões típicas nos linfonodos mesentéricos, renais e esplênicos, embora não houvesse lesões macroscópicas evidentes em outros órgãos. Este foi o primeiro caso de tuberculose em búfala, no Brasil ${ }^{271}$.

Freitas (1982) ${ }^{119}$ comunicou a ocorrência de tuberculose em um búfalo, 
também abatido em matadouro em Belém, Pará. Apesar do encontro de bacilos álcool-ácido resistentes nas lesões, o M.bovis não foi isolado ${ }^{119}$.

\section{g) BISÕES}

O maior reservatório selvagem da tuberculose bovina na América do Norte, é a população de bisão híbrido (mestiço) dentro e ao redor do Wood Buffalo National Park, na divisa entre Alberta e os Territórios Noroestes, no Canadá ${ }^{216,228,280}$. A infecção por M.bovis foi introduzida no parque entre 1925 e 1928 quando 6.673 bisões foram removidos de um rebanho infectado do National Buffalo Park perto de Wainwright, Alberta ${ }^{216}$. No período de 1923 a 1939 foram encontradas lesões tuberculosas em $6.450(53,7 \%)$ dos 12.005 bisões abatidos em Wainwright ${ }^{199,} 216$. Investigações epidemiológicas indicaram que a fonte de infecção, provavelmente, foi um bisão introduzido no parque, proveniente de outro rebanho, no qual o primeiro filhote capturado havia sido criado por uma vaca doméstica. Os rebanhos de bisões do National Buffalo Park foram abatidos e o parque desativado em $1940^{216}$.

Entre 1952 e 1956, 39\% de 1.508 bisões abatidos no Wood Buffalo National Park, tinham lesões tuberculosas, e em 1961, foram encontrados 151 (13,5\%) bisões tuberculina-positivos em 1.116 bisões testados ${ }^{199,216}$. O teste da tuberculina tem uma sensibilidade de $66,6 \%$ e especificidade de $89,6 \%$ em bisões ${ }^{216}$.

Entre 1959 e 1974, a prevalência de lesões tuberculosas em bisões abatidos neste parque variou de 20-50\%, com uma média de 39\% ${ }^{216}$. Entre 1983 e 1985, durante uma investigação dentro e ao redor deste parque canadense, 15 (21\%) de 72 bisões encontrados mortos, apresentavam lesões tuberculosas no exame post mortem, sendo que a distribuição dessas lesões sugeriu que a infecção ocorreu primariamente pela via respiratória. Em 14 (93\%) dos bisões tuberculosos, foram afetados os linfonodos retrofaringeais e/ou bronquiais. Concluiu-se que a doença havia sido endêmica e, consequentemente, havia um risco crescente de transmissão da infecção para bisões não infectados e populações bovinas ${ }^{199,216}$. 
Em 1992 houve um surto de infecção por M.bovis em um rebanho de bisões cativos em Oklahoma. Antes desse surto, os casos mais recentemente documentados em bisões cativos nos Estados Unidos ocorreram em 1984 e 1956. Em 1994, registrou-se nos Estados Unidos um total de 11 rebanhos de bisões infectados com tuberculose bovina ${ }^{216}$.

\section{h) CACHORROS E GATOS}

Cachorros e gatos são susceptíveis a infecções por M.bovis e M.tuberculosis, mas são relativamente resistentes à infecção pelo M.avium. As infecções causadas pelo M.tuberculosis são consideradas uma zoonose inversa, ou seja, a direção da transmissão é do homem para o animal, cuja prevalência é maior nos cães do que em gatos ${ }^{131}{ }^{157}$. No caso do cão, companheiro de um homem excretor eventual de bacilos, a contaminação ocorre, principalmente, por inalação ${ }^{117}$.

Cachorros e gatos podem adquirir a tuberculose bovina por meio de leite contaminado, pela ingestão de carne não cozida (restos de carnes e vísceras de animais abatidos em matadouros) ou pela via aerógena, por serem usados muitas vezes como sentinelas para gado leiteiro infectado por M.bovis, em pequenas fazendas 48, 92, 131,151, 168,173, 174, 181. Os gatos também são utilizados no combate biológico dos ratos, nos estábulos ${ }^{167}$.

Portanto, cães e gatos, podem ser potenciais disseminadores do M.bovis e a doença nesses animais se localiza, preferencialmente, no trato respiratório e no intestino, respectivamente ${ }^{131}$. Assim, as lesões nos cachorros são mais freqüentes nos pulmões do que em outros órgãos como o fígado e rins, e geralmente exsudativas e não calcificadas 117, 137, 261. Como o leite de vacas tuberculosas tem sido incriminado como a fonte de infecção mais comum para os gatos, o sitio primário da infecção é o trato digestivo, com aumento e necrose dos linfonodos mesentéricos. A propagação hematogênica resulta em doença progressiva em outros órgãos, incluindo os pulmões, com rara calcificação da lesão 117, 137, 178, 261 . 
Nas 2 espécies animais, a doença é de evolução rápida e caquetizante, na ausência de tratamento ${ }^{117,131}$. Devido à localização da infecção, os cães geralmente excretam o bacilo no escarro e os gatos, nas fezes ${ }^{131}$.

Na Europa, a infecção por M.bovis era relativamente comum em gatos antes do efetivo controle da tuberculose no gado. Em uma revisão da literatura, estudos de necropsia em gatos revelaram, na época, uma prevalência de tuberculose variando de 2 a $13 \%$ 178, 181, 216 . Em 1928, Griffith relatou que de 20 gatos tuberculosos naturalmente infectados, na Inglaterra, todos tinham como agente, o M.bovis ${ }^{216}$.

Em 1929, Stableforth registrou 5 casos de tuberculose em gatos devidos à infecção por M.bovis. Em um animal, as lesões estavam confinadas à cavidade torácica, e nos outros 4 , a infecção aparentava ter ocorrido por ingestão ${ }^{216}$. Francis, em 1958, demonstrou por meio de infecções experimentais com M.bovis, que gatos morriam em períodos médios de 28 a 42 dias, após a infecção ${ }^{151}$.

No período de 1966 a 1968, na Pennsylvania, Estados Unidos, o M.bovis foi isolado de $4(44,4 \%)$ dos 9 cachorros e de $24(46,2 \%)$ dos 52 gatos examinados por haverem sido expostos à bovinos afetados com tuberculose bovina, sugerindo assim, que gatos e cachorros podem ser envolvidos em uma extensão muito maior do que, geralmente, se imaginava ${ }^{181,216}$.

Em 1983, um surto de tuberculose devida ao M.bovis em gatos, foi relatado em Victoria, na Austrália. Concluiu-se que o caso índice foi infectado por ingestão de carne contaminada, e que alguns dos outros casos adquiriram a infecção por inalação do bacilo da tuberculose, proveniente de um abscesso supurado na região dos linfonodos submandibulares do caso índice ${ }^{151,216}$.

O M.bovis foi isolado de 57 gatos nos laboratórios de saúde animal na Nova Zelândia, no período de 1974 a 1986. Com a exceção de 6 gatos, todos eram provenientes de áreas rurais e suburbanas, onde o M.bovis também estava presente em animais silvestres e selvagens, especialmente, em gambás. Lesões tuberculosas na pele foram encontradas em 33 (58\%) gatos, em forma de abscessos nas costas, pernas, flancos e região inguinal. Os remanescentes apresentavam inchaços dos 
linfodos mesentéricos, torácicos, axilares e da cabeça ${ }^{178}$.

A presença de lesões nos linfonodos da cabeça, especialmente nos submandibulares, indicou a transmissão da infecção pela via oral. Provavelmente, essas infecções ocorreram como resultado de gatos comendo carcaças de animais selvagens tuberculosos ou lambendo suas lesões de pele, ao invés de beberem leite contaminado, uma vez que, praticamente todo o leite destinado ao consumo humano na Nova Zelândia era pasteurizado nessa época e mastite tuberculosa nas vacas era rara nas áreas endêmicas de tuberculose. Não foi encontrada a fonte de infecção do M.bovis, neste estudo ${ }^{178}$.

Em uma carta de 26 de março de 1994, o Dr. G.J. de Bolla relata que um gato doente da raça "chinchilla" com 3 anos de idade, apresentou um aumento anormal dos linfonodos submandibulares, em Wellington, Nova Zelândia. Foram realizadas várias biópsias e foi isolada uma micobactéria, posteriormente identificada como uma cepa com características intermediárias de M.tuberculosis e M.bovis. Muitas questões foram levantadas a respeito dessa cepa. Pesquisadores da Inglaterra, ao comentarem esse caso, afirmaram que este foi mais um, de uma série de 10 gatos, nos quais esta micobactéria foi isolada pelo Laboratório de Referência em Micobactérias; no entanto, as informações ainda eram insuficientes para explicar a origem e o potencial zoonótico desta cepa, mas pesquisas estavam sendo realizadas para atingir esse objetivo ${ }^{39,139,287}$.

Outro caso, relatado por Blunden e Smith $(1996)^{38}$, ocorreu em um gato doméstico de Kent, Inglaterra, no qual o bacilo da tuberculose com características entre M.bovis e M.tuberculosis foi isolado de linfonodos cervicais, mesentéricos e submandibulares. A fonte de infecção dessa nova espécie de tuberculose é incerta, mas a transmissão por meio de roedores é uma possibilidade, uma vez que esse gato era um caçador de roedores ${ }^{38}$.

Apesar de haver muitos relatos de tuberculose causada por M.bovis em gatos, até 1994 a doença era relativamente rara, nessa espécie animal, na Grã-Bretanha ${ }^{287}$.

No Brasil, são poucos os relatos de tuberculose por M.bovis em cães e gatos. 
Migliano (1970) ${ }^{187}$ relatou que no período de 1944 a 1959, foram diagnosticados 29 casos de tuberculose em cães na cidade de São Paulo, entre aproximadamente 60.000 animais examinados, considerando rara a incidência da tuberculose canina nesta cidade. A partir de 1959, quando já haviam sido descobertos meios terapêuticos eficazes no combate à tuberculose e até 1970 , o autor não teve a oportunidade de diagnosticar outro caso de tuberculose, na espécie canina ${ }^{187}$.

Após realizar uma extensa revisão bibliográfica sobre tuberculose canina e baseado na observação clínica dos 29 casos de tuberculose, acima descritos, o autor concluiu que o cão era considerado mais como uma vítima da domesticação do que um perigo iminente à saúde humana, havendo maior incidência de tuberculose em cães que habitavam grandes centros populacionais, do que naqueles que viviam em regiões rurais. Quanto à raça e idade, a tuberculose era mais freqüente em animais de grande porte e em alguns "terrieres", e em cães adultos com idade oscilando entre 2 e 7 anos ${ }^{187}$.

Kavinski e Kleiner Neto (1984) ${ }^{157}$, descreveram 3 casos de tuberculose em cães e 2 em gatos. Os 3 cães eram fêmeas, não tinham raça definida, e a idade variava de 6 a 8 anos. Em 2 animais, o diagnóstico foi confirmado durante a necropsia, mas em uma cadela de 6 anos de idade, que apresentava tosse e emagrecimento progressivo, a suspeita de tuberculose foi fornecida pelo raio $\mathrm{X}$ do tórax. A imagem radiográfica mostrou um aumento de tamanho dos linfonodos mediastínicos, nos quais foi realizada posteriormente uma biópsia, que revelou a presença de micobactérias ${ }^{157}$.

Em relação aos 2 gatos, 1 era siamês, macho, com 4 anos de idade. $\mathrm{O}$ outro era uma fêmea, sem raça definida, com 6 anos de idade. O primeiro gato apresentava convulsões e o exame radiológico evidenciou uma extensa osteomielite nos ossos da cabeça. O animal foi eutanasiado e o diagnóstico de tuberculose foi confirmado. O segundo animal apresentava caquexia progressiva, foi a óbito logo a pós o internamento na clínica, e a necropsia revelou uma tuberculose digestiva, havendo lesões também nos linfonodos mediastínicos. Em nenhum dos 2 casos os autores puderam identificar a micobactéria. Em todos os casos os proprietários foram 
cientificados da gravidade e aconselhados a procurar a unidade de vigilância sanitária $^{157}$.

Cruz e col. (1987) ${ }^{88}$, descreveram 1 caso de tuberculose pulmonar em 1 cão pastor belga, com 3 anos de idade. Na necropsia, o animal apresentou lesões na cavidade torácica, sendo que microscopicamente observou-se uma grande quantidade de bacilos álcool-ácidos resistentes ${ }^{88}$.

As implicações zoonóticas e o risco de infecção para o homem e outros animais, combinadas com as dificuldades de um tratamento prolongado com antibióticos e a incerteza de obtenção de resultados, são argumentos contra a tentativa de cura de cães e gatos tuberculosos ${ }^{157,287}$. Entretanto, atualmente a medicação crescente em animais de companhia, e do cão em particular, faz com que problemas respiratórios do tipo bronquite sejam, freqüentemente, tratados com antibióticos, como a estreptomicina, parcialmente ativa sobre os bacilos da tuberculose. Isto pode ocultar a evolução típica de uma tuberculose canina. Este fato não deve ser negligenciado em relação aos gatos ${ }^{117}$.

\section{i) CABRAS}

Estudos indicaram que as cabras são susceptíveis ao M.bovis, mas, freqüientemente, resistentes ao M.tuberculosis ${ }^{137,216}$.

A infecção por M.bovis em cabras pode ocorrer por contato direto com animal doente, ou por alimento contaminado e causar doença progressiva e generalizada, cujos sinais são dor ao respirar, tosse rouca, perda de peso e diminuição na produção de leite ${ }^{48,87}$.

As cabras são animais pouco exigentes e se adaptam facilmente a todos os climas, por isso, a utilização e produção de seu leite ocorre no mundo todo. O leite da cabra pode ser recomendado a crianças e adultos alérgicos ao leite de vaca. A fabricação de queijos de leite de cabra constitui uma verdadeira indústria, sobretudo na França, onde os queijos são consumidos frescos ou fermentados. Também é 
utilizado na fabricação de manteiga e iogurte ${ }^{195}$. Como cabras leiteiras também são vítimas de mastite tuberculosa, seu leite pode constituir um perigo para o consumidor $^{216}$.

Nos Estados Unidos, registros obtidos no período de 1926 a 1936, mostraram que entre, aproximadamente, 317.000 cabras examinadas pelo Bureau of Animal Industry (BAI), apenas $1(0,0003 \%)$ caso de tuberculose foi encontrado ${ }^{216}$.

Em abatedouros, na Alemanha, estatísticas revelaram uma incidência de 0,7\% para o período de 1904 a 1920 , e $1,02 \%$ para o período de 1920 a $1937^{216}$.

Em 1939, Carmichael revisou cuidadosamente a literatura sobre tuberculose em cabras e descreveu as condições em Uganda, África, onde as cabras compartilhavam cabanas com os nativos durante a noite. Apesar desse íntimo contato entre homens e animais, as 10 cepas de bacilos isoladas de cabras eram do tipo bovino, e todas as cepas isoladas dos nativos eram do tipo humano ${ }^{216}$.

Em 1958, Francis disse que a tuberculose em cabras era rara na GrãBretanha e muitos outros países. Contudo, ele também afirmou que a tuberculose poderia ocorrer em $1 \%$ das cabras em alguns países europeus, quando mantidas em rebanhos que estavam em contato com o gado. Mais recentemente, apenas casos isolados de tuberculose em cabras ocorreram na Grã-Bretanha, desde um grave surto observado em um rebanho experimental de 75 cabras ${ }^{216}$.

Infecções por M.bovis em rebanhos de cabras leiteiras ocorreram também no nordeste da Espanha, onde foram encontrados 19 rebanhos infectados, sendo que o principal sinal clínico era o emagrecimento. A mortalidade era alta, variando de $20 \%$ a mais que $50 \%$ ao ano, em diferentes rebanhos. Exames post mortem mostraram lesões de tuberculose pulmonar crônica, com a presença de nódulos grandes e caseosos e áreas com cavitações. Essas lesões foram confirmadas em 65 animais ${ }^{216}$.

Em 1990, na Espanha, 77\% das 251 cabras provenientes de 2 rebanhos distintos, foram encontradas positivas ao teste da tuberculina e o M.bovis foi isolado em $10(28,6 \%)$ de 35 cabras reatoras e necropsiadas ${ }^{87}$. 
Cabras selvagens com prevalências de tuberculose acima de $3,1 \%$, dentro de grupos distintos, foram encontradas em áreas endêmicas de tuberculose na Nova Zelândia ${ }^{199,216}$. A significância epidemiológica da infecção por M.bovis em cabras selvagens, é geralmente considerada como mínima, mas em países desenvolvidos com avançados programas de erradicação da tuberculose bovina, cabras domésticas são monitoradas, para prevenir a infecção por M.bovis, uma vez que, quando infectadas, freqüentemente, sofrem de tuberculose pulmonar e são capazes de reinfectar o bovino ${ }^{216}$.

O diagnóstico da tuberculose nesses animais é feito usualmente na necropsia. Apesar das cabras serem sensíveis à tuberculina, um diagnóstico confirmatório é necessário porque o M.avium também produz tuberculose disseminada nessas espécies animais ${ }^{261}$.

Não foram encontrados registros de tuberculose por M.bovis em cabras no Brasil.

\section{j) CARNEIROS}

Em geral, a natureza do carneiro agrícola e a limitada exposição direta a fontes animais tuberculosas fazem com que a doença por M.bovis seja rara, mesmo nos locais em que a exposição a animais selvagens é considerada um risco $^{181,199,216,261}$. Muito ocasionalmente, prevalências acima de 5\% são observadas em rebanhos de carneiros na Nova Zelândia ${ }^{181,199,216}$. Os carneiros não são muito susceptíveis à tuberculose e mesmo quando pastam junto a bovinos severamente

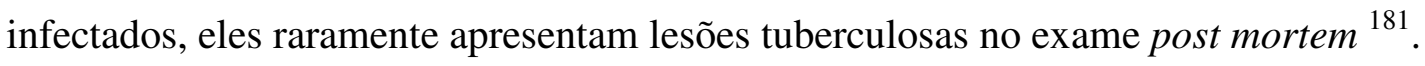

Diferenças comportamentais entre o carneiro e o bovino devem influenciar esse quadro, uma vez que o carneiro ao se deparar com um gambá morto ou em estágio terminal, provavelmente, não irá lamber ou cheirar as carcaças infectadas, enquanto o bovino, por ser muito mais curioso, irá se expor à infecção ${ }^{199,216}$.

Em 1913, Chaussé demonstrou que 1 a 5 bacilos foram suficientes para 
produzir uma lesão pulmonar em carneiros, quando introduzidos com um fino spray, ao passo que 13 milhões de bacilos foram necessários para infectá-los pela via oral. Comprovou assim, a importância da via aerógena na transmissão da tuberculose por M.bovis $199,205,216$.

Durante um surto epidêmico em uma fazenda na Nova Zelândia, 108 (18\%) de 596 carneiros foram positivos ao teste tuberculínico, quando injetados com tuberculina bovina. Lesões semelhantes à tuberculose foram encontradas em 43 (61\%) dos 70 reatores, abatidos em matadouros. A distribuição das lesões sugeriu infecção por ingestão em $5 \%$ dos carneiros e em $48 \%$ por inalação. Foi reportado também, que $43(0,3 \%)$ de 15.000 carneiros que pastaram em uma propriedade com uma história de severa e extensa tuberculose em gambás e gado, estavam tuberculosos. O M.bovis foi recuperado de $32(74,4 \%)$ dos 43 animais com lesões tuberculosas, e essas lesões sugeriram uma rota oral de infecção ${ }^{216}$.

Foram registrados no período de 1900 a 1980, apenas 8 casos confirmados de infecção por M.bovis, em carneiros, na Grã-Bretanha ${ }^{216}$.

No Brasil, não foram encontrados casos de tuberculose por M.bovis em carneiros.

\section{k) CAVALOS, JUMENTOS E MULAS}

O cavalo é naturalmente susceptível aos 3 tipos de bacilos da tuberculose (M.tuberculosis, M.bovis e M.avium). Portanto, a infecção por M.bovis pode ocorrer nesses animais, mas não é de significância epidemiológica 136, 199, 216, 261 . Os equinos adquirem o M.bovis frequentemente pela via digestiva, atravé da contaminação da água e ração (criação em promiscuidade) ou pelo leite de vaca tuberculosa utilizado na alimentação de potros ${ }^{48}$.

Em 1941, uma revisão de literatura mostrou que entre 75 cepas do bacilo da tuberculose, isoladas de casos de tuberculose em eqüinos, 69 (92,0\%) eram do tipo bovino, $5(6,7 \%)$ do tipo aviário e $1(1,3 \%)$ do tipo humano ${ }^{216}$. 
Em 1958, Francis detalhou registros de tuberculose bovina devida ao M.bovis em 15 cavalos e um registro de tuberculose devida ao M.tuberculosis em 1 cavalo. Observou que o cavalo, como o cachorro, apresentava a peculiaridade de um animal no qual a tuberculose espontânea não era comum, mas a condição uma vez estabelecida era maligna. Contudo, parecia existir um longo período de latência, porque muitas infecções em cavalos deviam ser adquiridas quando recebiam leite contendo o bacilo da tuberculose, enquanto potros. Já a tuberculose em potros era incomum e a maioria dos casos observados ocorriam entre 5 e 10 anos de idade. $\mathrm{O}$ pulmão parecia ser particularmente susceptível à propagação hematogênica. Muitas das cepas bovinas isoladas de cavalos eram de baixa virulência ${ }^{216}$.

Francis disse também que a incidência de tuberculose em cavalos variava de 0,01 a 0,07\% na França e acima de 0,46\% na Alemanha e Dinamarca. Nos cavalos, as lesões têm aparência tumoral, ou seja, o baço aumenta 10 vezes o seu tamanho, com simultâneo aumento dos linfonodos mesentéricos ${ }^{216}$.

A tuberculose tem sido ocasionalmente registrada em jumentos e mulas, e as lesões são similares às dos cavalos. Em 1929, Stableforth registrou o isolamento de M.bovis em uma mula de 17 anos, que tinha ulcerações tuberculosas no intestino e linfonodos mesentéricos aumentados ${ }^{216}$.

Em 1949, Kesten descreveu um caso de tuberculose em uma mula importada, no sul da Irlanda, em 1917, no qual ambos os pulmões apresentavam lesões miliares e os linfonodos mediastinos e bronquiais apresentavam lesões caseosas, nas quais foram observados bacilos álcool-ácido resistentes ${ }^{216}$.

No Brasil, Macruz e col. (1974) ${ }^{166}$, relataram 3 casos de tuberculose em eqüinos puro sangue inglês, de 1.288 necropsias realizadas no Jockey Club de São Paulo, no período de 1960 a 1974. Na necropsia, observaram-se lesões generalizadas na tireóide, coração, diafragma, fígado, baço, sistema nervoso central (cerebelo) e gânglios mediastínicos, mesentéricos, renais e esplênicos, com grandes quantidades de bacilos álcool-ácido resistentes, que posteriormente foram identificados como M.bovis ${ }^{166}$. 


\section{I) CAMELOS E OUTROS ANIMAIS DE CASCO}

Nos Estados Unidos, camelídeos e outros exóticos animais de casco, não tiveram um papel significante na propagação do M.bovis, mas o potencial para que isso ocorra existe, principalmente por meio do contato inter-espécies em leilões, parques de caça ou zoológicos não registrados. Recomenda-se que, para prevenir a transmissão do M.bovis entre espécies, os animais exóticos de casco não devam manter contato direto ou indireto com animais domésticos. Nos Estados Unidos, são considerados animais exóticos, todos os camelídeos, bovídeos e cervídeos (mas não equídeos) que residam em zoológicos ou parques de caça, que pertençam a comerciantes privados, ou que participem de exposições ${ }^{216}$.

Os camelos contraem a infecção por M.bovis através da via digestiva, quando jovens, e pela via aerógena, quando adultos. Eles excretam os bacilos no escarro, saliva, leite e fezes ${ }^{163}$.

O leite de camela é muito mais espesso e gorduroso que o da vaca e é consumido em todos os países desérticos ou semidesérticos, onde o camelo representa a única espécie de mamífero doméstico ${ }^{195}$.

No grupo dos camelídeos encontramos: lhamas, alpacas, lhamas guanaco, lhamas vicuna e dromedários, e camelos da raça "bactrian". No dos bovídeos: oryx, gazela, kudu, bisão, búfalo, antílope e muitos outros. E no grupo dos cervídeos estão incluídos, entre outros: alces, moose (grandes alces americanos) e uma variedade de cervos $^{216}$.

Acredita-se existir um perigo real de que exóticos animais de casco, quando capturados, possam reintroduzir a infecção por M.bovis em países desenvolvidos ${ }^{216}$.

Em 1907, Mason revisou relatos anteriores de tuberculose em camelos, e observou que a tuberculose nesses animais era incomum, exceto no Egito. No período de 1910 a 1916, dos 7.411 camelos da raça dromedário, mortos em abatedouros no Cairo, 218 (2,9\%) estavam tuberculosos por M.bovis. Ele encontrou 
tuberculose em camelos das raças "syrian" e "arabian", apenas naqueles que tinham estado no Egito e por um período de tempo considerável. Os camelos no Egito eram, freqüentemente, mantidos em íntimo contato com bovinos e a rota de infecção era usualmente o trato respiratório. De todos os casos relatados, 60,0\% apresentavam lesões restritas aos pulmões e linfonodos bronquiais ${ }^{216}$.

Um número limitado de infecção por M.bovis em camelídeos cativos, foi revisto nos Estados Unidos. A tuberculose devida ao M.bovis foi registrada em um rebanho de fêmeas, de 19 camelos da raça "bactrian" e espécie Camelus bactrianus, mantidos em um zoológico de Virgínia ${ }^{216}$.

No período de 1971 a 1976, nos Estados Unidos, dos 85 isolamentos de micobactérias em animais de casco cativos, 46 (54\%) cepas eram M.bovis, provenientes de lhamas, kudus, antílopes, bisões, cervos, alces e de um tapir ${ }^{260}$.

Para muitos, lhamas e alpacas eram consideradas um investimento financeiro, e, além disso, um símbolo de status. Em 1973, o M.bovis foi confirmado em uma lhama de um zoológico no Colorado, e o segundo caso em lhama foi encontrado no mesmo zoológico em 1974. Consequentemente, as 30 lhamas remanescentes no rebanho foram abatidas em junho de 1974, sendo que lesões tuberculosas foram encontradas em $15(50 \%)$ dos animais examinados ${ }^{216}$.

Em 1993, 2 camelos exportados da Suécia para os Estados Unidos, foram diagnosticados com infecção por M.bovis, enquanto estavam sob quarentena de importação nos Estados Unidos. Estimou-se que neste ano, aproximadamente $98 \%$ dos camelídeos americanos estavam em propriedades privadas e os outros $2 \% \mathrm{em}$ zoológicos $^{216}$.

A infecção tuberculosa por M.bovis foi diagnosticada em 13 alpacas em 2 diferentes fazendas na Holanda em 1988. Esses animais haviam sido importados da América do Sul ${ }^{216}$. 


\section{m) FURÕES}

Em 1953, houve um caso de tuberculose por M.bovis em um furão de laboratório na Inglaterra, que apresentou um número enorme de bacilos nos tecidos $^{181}$.

A ocorrência da infecção por M.bovis tem sido registrada em furões selvagens da espécie Mustela putorius furo, na Nova Zelândia. O primeiro isolamento de M.bovis foi obtido em 1982. Subseqüentemente, o M.bovis foi isolado em mais 25 furões selvagens. Uma característica da doença nos furões infectados foi a alta proporção de casos que apresentavam um grande número de bacilos álcool-ácidos resistentes nas lesões. Aparentemente, a Nova Zelândia tem uma das maiores populações de furões selvagens no mundo ${ }^{216}$.

Os furões se alimentam principalmente de pequenos mamíferos, e as maiores densidades desses animais, são encontradas naquelas áreas com moderado ou grande número de coelhos. Em todas as áreas onde furões foram encontrados, existiam casos de tuberculose no gado ou cervos. Alguns furões infectados estavam em áreas da Nova Zelândia, nas quais existiam baixos números de gambás ${ }^{216}$.

O possível papel de furões tuberculosos como uma fonte de infecção para conjuntos de animais domésticos permanece indeterminado, mas concluiu-se que mesmo que não haja propagação da infecção para outros hospedeiros, os furões podem ser uma espécie indicadora e acessível para exames, quando se estiver buscando reservatórios selvagens de M.bovis na Nova Zelândia ${ }^{216}$.

\section{n) ROEDORES}

Em 1939, Griffiths descreveu na Inglaterra o isolamento de um bacilo muito virulento em um ouriço que havia morrido de pneumonia. Provavelmente, esse bacilo foi o M.bovis ${ }^{181}$.

Estudos realizados em 1982 descreveram o isolamento de M.bovis em ouriços 
na Nova Zelândia. Entretanto, o número de casos foi pequeno e esses animais não foram considerados importantes fontes de infecção para o bovino ${ }^{181}$.

Em 1940, o M.bovis foi isolado de 2 ratos capturados na Inglaterra, mas que não apresentaram lesões no exame post mortem $^{181}$.

O rato marrom (Rattus norvegicus) foi descrito por Francis em 1958 como o mais resistente de todos os animais à tuberculose, pois a inoculação de um grande número de M.bovis, não produziu lesões nesses animais. Contudo, estudos anteriores haviam demonstrado que alimentando-se ratos com material infectado, encontrava-se grande número de bacilos nos linfonodos mesentéricos, apesar da não formação de lesões. Devido à natureza não progressiva da doença, os ratos são considerados hospedeiros terminais do M.bovis ${ }^{181}$.

Existe apenas um caso registrado de tuberculose causada por M.bovis em um coelho selvagem da espécie Oryctolagus cuniculus cuniculus, na Nova Zelândia. O coelho, capturado por um cachorro que pertencia a um trabalhador morto por tuberculose, estava em más condições (apesar dos abundantes recursos alimentares), e tinha extensas lesões no pulmão e rins. Este foi o único caso descrito na literatura até 1995, e reforçou a crença de que coelhos, provavelmente, não teriam importância epidemiológica na transmissão da doença a animais domésticos ${ }^{181,216}$.

O coelho é uma espécie animal intrigante, porque é susceptível à infecção experimental, mas sob condições de campo, não atinge prevalência detectável, apesar de possuir todos os ingredientes necessários para se tornar um reservatório da doença $^{135,199}$.

Em 1959, foram encontrados casos de infecção por M.bovis em minks em 15 fazendas da Inglaterra, que apresentavam numerosas lesões tuberculosas ${ }^{181}$.

Em 1979, o M.bovis foi isolado de 2 toupeiras em uma fazenda de Cornwall, Inglaterra, onde bovinos e texugos estavam tuberculosos, mas nenhuma lesão foi encontrada ${ }^{181}$.

No período de 1982 a 1983, foram registrados na Argentina 5 (1,4\%) casos 
de infecção por M.bovis em lebres (Lepus leporis ), de um total de 369, que haviam sido condenadas no exame post mortem ${ }^{216}$.

No Brasil, Portugal e col. (1990) ${ }^{227}$, descreveram um surto de tuberculose em criação de chinchilas, que acometeu a totalidade dos animais de um plantel situado no município de Campos de Jordão, São Paulo ${ }^{227}$.

As chinchilas (Chinchilla laniger) são roedores de tamanho médio, que habitavam originalmente as regiões montanhosas do Peru, Bolívia, Chile e Argentina, vivendo em altitudes de até 6.000 metros. Historicamente, o povo Inca utilizava sua pele para a confecção de roupas e sua carne para a alimentação. Em virtude da grande procura por sua valiosa pele, estes animais foram caçados sistematicamente ao longo dos séculos, e hoje, apenas em raríssimas ocasiões são encontrados na vida nativa. Conseqüentemente, as chinchilas foram sendo paulatinamente adaptadas à vida de cativeiro, e o confinamento, se por um lado preservou a espécie, levou ao surgimento de problemas sanitários variados ${ }^{227}$.

Neste surto, com a realização da necropsia de alguns exemplares, estabeleceuse a suspeita clínica de tuberculose, e decidiu-se pela aplicação do teste tuberculínico comparativo em todos os animais remanescentes, que perfaziam um total de 52 chinchilas. Desse total, 36 animais morreram no período de 72 horas compreendido entre o momento da inoculação e a leitura da prova. A necropsia mostrou uma nítida generalização da doença, evidenciando uma reagudização da tuberculose após a inoculação das tuberculinas, havendo o comprometimento de vários órgãos ${ }^{227}$.

Foram realizados exames bacteriológicos e histopatológicos, encontrando-se bacilos álcool-ácido resistentes nas lesões e isolando-se o Mycobacterium sp., sem a identificação da espécie. A fonte de infecção foi um dos tratadores dos animais, menor de idade, contratado para os serviços de limpeza das gaiolas e distribuição dos alimentos, que era portador de tuberculose pulmonar. Face ao quadro geral da doença na criação, os poucos animais remanescentes foram sacrificados, as instalações sofreram rigorosa desinfecção, e recomendou-se maior rigor na seleção dos tratadores a serem contratados 227 . 
A tuberculose em chinchilas tem raros registros na literatura. No Brasil, além deste caso, não há registro da doença acometendo outros animais de peleteria ${ }^{227}$.

\section{o) FOCAS}

Em 1986, ocorreu tuberculose devida ao M.bovis em um leão marinho cativo australiano (Neophoca cinerea), em peles de focas neozelandesas (Arctocephalus forsteri) e em uma foca australiana (Arctocephalus pussillus doriferus) em um Parque Aquático, perto de Perth, na Austrália Ocidental. Em 1993, registrou-se 3 casos de tuberculose em focas selvagens encontradas mortas na costa sul da Austrália Ocidental $^{216}$.

$\mathrm{Na}$ costa Atlântica da Argentina, em 1993, encontrou-se 4 focas (Arctocephalus australis) e um leão marinho (Octavia flavescens) tuberculosos por M.bovis ${ }^{216}$.

\section{p) ANTÍLOPES}

$\mathrm{Na}$ África, em Zâmbia, existia a suspeita de longa data, que antílopes de pântano, da espécie Kobus lechwe, que viviam no Lochinvar Game Reserve, sofriam de alta incidência de tuberculose por M.bovis. Por esse motivo, Clancey realizou um estudo em 1977, em 238 amostras de tecidos (principalmente pulmão e linfonodos mediastínicos e mesentéricos), provenientes de 70 antílopes sacrificados nessa reserva, e conseguiu isolar cepas de M.bovis em 28 (40\%) antílopes de pântano silvestres 59 .

Dillman, em 1976, havia estabelecido um ciclo de infecção entre bovinos e antílopes dessa região. Sugeriu que, desde que as 2 espécies animais passaram a se alimentar nas mesmas áreas, um reservatório da doença em antílopes, poderia ter induzido uma persistência da infecção no gado 59 .

Casos de tuberculose por M.bovis em grandes antílopes da raça "kudu" e 
espécie Tragelaphus strepsiceros, e antílopes da raça “duiker" e espécie Sylvicapra grimmia, foram relatados na África do Sul ${ }^{216}$.

A tuberculose é endêmica na população de antílopes da raça "red" do rio Kafue, os quais pastam com o gado do distrito de Monze ${ }^{75}$. Estudos posteriores serão necessários, para determinar a incidência da tuberculose no bovino e no homem, em vários distritos da Zâmbia e a extensão geográfica da doença no antílope $^{59}$.

O oryx da raça "arabian” e espécie Oryx leucoryx é um antílope de tamanho médio, pesando entre 80 e $100 \mathrm{~kg}$. Foi considerado extinto na vida selvagem em 1972, mas foi salvo da completa extinção pelos programas de criação cativa em zoológicos americanos. Em 1986, o National Wildlife Research Center foi estabelecido pelas autoridades da Arábia Saudita, para criar e desenvolver estoques de animais da fauna nativa árabe, incluindo o oryx, para sua eventual reintrodução na vida selvagem. Nessa época, o número total de oryx cativos, não excedia 1.000 animais $115,132,265$.

Um surto de tuberculose devida ao M.bovis no rebanho de oryx da raça “arabian" mantidos no NWRC, tornou-se um dilema para as autoridades. Surtos de tuberculose bovina haviam sido resolvidos, mais efetivamente, com a política de teste tuberculínico e abate dos animais tuberculina-positivos, mas o extremo valor genético do rebanho de oryx, e a grande ligação cultural que os líderes do Reino da Arábia Saudita tem por esses animais, impediram qualquer tentativa de destruí$\operatorname{los}^{115,132}$.

Em abril de 1986, 57 oryx foram transportados ao NWRC, originários de uma coleção particular do Rei Khalid em Thumamah perto de Riyadh. Em junho, um animal morreu repentinamente devido à tuberculose e em setembro do mesmo ano, 16 animais morreram da doença. A alta incidência de lesões nos pulmões e cavidade torácica indicou a via aerógena de infecção. A captura dos oryx e seu prolongado confinamento, quando transportados em engradados comuns em um dia de muito calor, proporcionou uma oportunidade ideal para a transmissão da tuberculose, por meio da inalação de aerossóis, entre os oryx e deles para outros animais que estavam 
em íntimo contato, como cervos da raça "fallow" e espécie Dama dama 115, 132, 265.

Em maio de 1987, 9 oryx estavam infectados, e foram tratados com uma mistura de isoniazida, etambutol e rifampicina, administrados diariamente durante 9 meses. Essa medida resultou na interrupção das mortes, na diminuição do risco de infecção para os outros animais e na produção de oryx livres de tuberculose para sua reintrodução na vida selvagem ${ }^{115,132,265 .}$

A eliminação da tuberculose neste rebanho de oryx teve um custo muito alto, só justificado pela raridade dessa espécie animal e pelo seu grande valor genético $^{132,265}$.

No leste da África, foram encontrados em 1976, 3 oryx da raça "beisa" e espécie Oryx gazella beisa, com tuberculose causada pelo M.bovis ${ }^{115}$.

\section{2- ETIOLOGIA}

\subsection{1- AGENTE ETIOLÓGICO}

O Mycobacterium bovis está posicionado taxonomicamente no

GÊNERO: Mycobacterium (Lehmann e Neumann, 1896)

FAMÍLIA: Mycobacteriaceae (Chester, 1897)

ORDEM: Actinomycetales

CLASSE: Schizomycetes

TIPO: Tallophyta

REINO: Vegetal ${ }^{8,69}$.

A inclusão destes microrganismos no reino vegetal foi aceita somente com o propósito de facilitar a classificação, pois na realidade não são verdadeiros vegetais, e tão pouco animais ${ }^{8,69}$. 
O M.bovis é um bacilo microaerófilo; desprovido de motilidade, esporos ou cápsulas; delgado, medindo 1,5 a $4,0 \mu$ de comprimento por 0,2 a $0,6 \mu$ de largura e álcool-ácido resistente (BAAR) 32, 55, 78, 115, 125, 142, 201, 236, 237, 281.

\subsection{2- CARACTERÍSTICAS MORFOLÓGICAS, TINTORIAIS E DE CULTIVO}

Uma das características mais notáveis das micobactérias e, consequentemente, do M.bovis, é o seu alto teor de lípides, cuja concentração atinge até $40 \%$ do peso seco das células e $60 \%$ da parede celular ${ }^{2,34,53,192}$. Com o auxílio da microscopia eletrônica, identificaram-se na rígida parede micobacteriana, 3 camadas dispostas de fora para dentro: uma lipoprotéica, uma polissacarídica e a mais interna mucopeptídica ${ }^{236}$. A estrutura química da parede celular das micobactérias é complexa, incluindo peptidoglicanos, arabinogalactanos, ácidos micólicos e superficialmente, uma variedade de lipídios, entre os quais peptidoglicolipídios e glicolipídios como os sulfolipídios ${ }^{32,53,93,228 .}$

Entre os micolatos foram isolados componentes responsabilizados por ações biopatológicas definidas: o ácido ftióico, produtor do gigantócito e folículo tuberculoso; o ácido tubérculo-esteárico, formador da caseose; o ácido micólico, responsável pela ácido-resistência e outros componentes com propriedades imunizantes e alergizantes ${ }^{236}$.

O alto teor de lípides da parede celular é responsável, entre outros fatores, pelo seu crescimento relativamente lento (cerca de 18 a 20 horas de tempo de divisão) e torna esses bacilos impermeáveis a vários corantes hidrossolúveis $^{74,142,223,282}$.

A combinação de anilina ou fenol ao corante fucsina permite a penetração deste último na parede celular, onde o mesmo interage com vários lipídios e, portanto, não é removido pela ação de soluções álcool-ácidas. Por este motivo, eles são denominados bacilos álcool-ácidos resistentes ou BAAR 53, 74, 78, 137, 142, 223. Alguns gêneros como Nocardia, Corynebacterium e Rhodococcus também contém 
espécies parcialmente ácido-resistentes, que podem ser confundidas com micobactérias $^{32,201,228}$.

O método de coloração do bacilo, originalmente utilizado por Koch, consistia em tratar os esfregaços durante 24 horas com uma solução alcalina de azul de metileno. Foi Paul Ehrlich em 1882 quem primeiro assinalou a propriedade tintorial característica do bacilo da tuberculose, a ácido-resistência, ao observar que os bacilos corados durante 15-30 minutos com violeta de metila ou fucsina básica em óleo de anilina, resistiam ao descoramento pelo ácido nítrico 1:3. Ao mesmo tempo, Ziehl descobriu um método muito semelhante ao de Ehrlich, no qual o óleo de anilina havia sido substituído por fenol; modificação que melhorava notavelmente a estabilidade da coloração. Neelsen, em 1883, introduziu o uso de fucsina ao invés de violeta de metila e empregou o ácido sulfúrico no lugar do nítrico ${ }^{8,34,137 .}$

Uma ligeira modificação, como a coloração a quente para a evidenciação da micobactéria, constituiu o que hoje se conhece pelo método de Ziehl-Neelsen, no qual o bacilo cora-se de vermelho brilhante sobre um fundo azul ${ }^{8,34,93,137}$.

Atualmente, utilizam-se esfregaços corados por corantes fluorescentes, particularmente, por auramina. Os bacilos corados desse modo aparecem no campo de visão iluminados com luz ultravioleta, na forma de bastões amarelados e luminosos $8,53,93$.

Quanto ao desenvolvimento dos bacilos em meios de cultura artificiais, foi Robert Koch o primeiro que conseguiu cultivá-los "in vitro". Como meio de cultura, Koch utilizou o soro sangüíneo bovino coagulado pelo calor, obtendo o crescimento do bacilo em forma de véus na superfície do soro ${ }^{8,110,137}$. No entanto, o crescimento do bacilo de Koch nos meios mencionados foi muito escasso e, em muitos casos, até inibido pelo desenvolvimento da flora associada ou por contaminação acidental durante a semeadura ${ }^{8,110}$.

As descobertas posteriores, feitas por diferentes pesquisadores, contribuíram para um notável melhoramento das técnicas em questão. Assim Nocard e Roux, em 1887, observaram que os bacilos da tuberculose humana se desenvolviam muito 
melhor nos meios adicionados de glicerina ou glicerol na proporção de 2 a $8 \%{ }^{8,110 \text {, }}$ 137. Posteriormente se comprovou que a glicerina poderia ser considerada como um fator inespecífico necessário para o crescimento de muitas micobactérias em meios artificiais, particularmente dos bacilos da tuberculose humana (M.tuberculosis) e aviária (M.avium). Entretanto, as concentrações usuais de glicerina nos meios de cultura (2 a 5\%) poderiam representar um sério obstáculo para o crescimento dos bacilos da tuberculose bovina (M.bovis). Jensen propôs o uso de meios (Lowentein) com baixa concentração de glicerina $(0,75 \%)$, com a finalidade de proporcionar condições relativamente favoráveis tanto para as cepas glicerinófobas como para as glicerinófilas ${ }^{8,110}$.

Pavlovsky foi o primeiro que empregou substâncias vegetais, demonstrando as excelentes qualidades da batata como novo substrato ${ }^{8}$.

Proskauer e Beck, em 1894, observaram que os bacilos da tuberculose poderiam desenvolver-se em meios sintéticos livres de proteína e que os elementos indispensáveis para o seu crescimento artificial eram: nitrogênio, carbono, oxigênio, hidrogênio, fósforo, potássio e magnésio. Contudo, para um crescimento mais exuberante era necessário anexar ao meio de cultura pequenas quantidades de ferro, enxofre, sódio, citratos e outros sais de ácidos polivalentes ${ }^{8}$.

Dorset, em 1902, preparou um meio de cultura a base de ovo, ingrediente que ainda é considerado como ótimo para o desenvolvimento e conservação das micobactérias, particularmente do bacilo da tuberculose ${ }^{8,110,137}$. Devido ao alto teor de lípides da parede celular, o crescimento da micobactéria é fortemente estimulado pela incorporação de glicerina e de lípides (gema de ovo) ao meio de cultura ${ }^{34}$. Os componentes desse meio serviram, posteriormente, como ponto de partida na elaboração de meios modificados. Surgiram diferentes meios de cultura de alta especificidade seletiva, tais como o meio de Petroff, Lowenstein, Petragnani, Hohn e outros, sendo que todos tinham em sua composição o ovo e outras substâncias recomendadas por Dorset ${ }^{8,110}$.

Dubos introduziu uma importante modificação, adicionando a um meio líquido semi-sintético um detergente aniônico, o Tween 80, que além de estimular o 
crescimento, tornava hidrófila a superfície do bacilo e, deste modo, propiciava um crescimento disperso ${ }^{34}$.

Quanto ao cultivo do M.bovis, em particular, com a introdução do piruvato de sódio no meio de cultura a base de ovo, desenvolvido por Stonebrink, obtiveram-se melhores resultados do que com os outros meios ${ }^{8,53,74}$. Em um isolamento primário, o crescimento do M.bovis em meios de cultura que contenham glicerol é muito pobre, mas repetidas subculturas permitem sua adaptação ao meio. Entretanto, para que ele cresça melhor, o glicerol deve ser substituído pelo piruvato de sódio ${ }^{52,74,77,192 .}$

Nos meios de cultura a base de ovos, a gema do ovo é um constituinte empregado para a obtenção de meios ricos em lipídios, pelos quais as micobactérias têm uma preferência especial. Estes meios, geralmente, são constituídos por soluções reguladoras à base de fosfatos, certos cátions em concentrações muito baixas, uma fonte de carbono (glicerol), outra de nitrogênio (asparagina no meio de LowensteinJensen), ou uma fonte de ambos os elementos (piruvato no meio de Stonebrink), e verde de malaquita como protetor contra a contaminação ${ }^{34,53,74,192 .}$

Pelo fato de ser microaerófilo, o M.bovis cresce melhor nos meios de cultura a base de ovo, quando incubado na presença de $5 \%$ de $\mathrm{CO}_{2}{ }^{77}$. Quando semeado em meios à base de ágar líquidos, semi-sólidos ou sólidos, ele cresce, mas não na superfície, turvando o meio de cultura, o que o distingue do M.tuberculosis que é altamente aeróbico ${ }^{32}$. A maioria das micobactérias de interesse humano e animal têm como temperatura ótima de crescimento $35-37^{0} \mathrm{C}^{192}$.

Enquanto as colônias do M.tuberculosis, nos meios de ovo com glicerina, geralmente são rugosas, secas, salientes, de contornos irregulares, pigmentadas de amarelo e com crescimento abundante ou eugônico, as colônias do M.bovis são pequenas, planas, secas, sem pigmento, com bordas irregulares, superfície granular com uma pequena protuberância e com crescimento pobre ou disgônico ${ }^{4,8,34,52,78,110,137,196,236}$. Entretanto, no meio de Stonebrink com piruvato de sódio, as colônias do M.bovis podem ser brancas, úmidas, brilhantes, lisas, convexas (semelhantes às de M.avium) e com crescimento eugônico ${ }^{2,52}$. 
Nos meios a base de ágar, as colônias do M.bovis são brancas ou incolores, escassas, sem brilho, rugosas, irregulares e planas com um montículo central ${ }^{52,78}$.

Em relação aos métodos de descontaminação dos espécimes clínicos submetidos à cultura, Uhlenhuth e Xilander, em 1908, propuseram o uso de antiformina (uma mistura de hidróxido de sódio e soda clorada) para dissolver os detritos celulares e atacar a flora associada nos escarros ou outro material designado para o cultivo dos bacilos tuberculosos $8,110,137$.

Petroff, em 1915, comunicou que o emprego da solução de soda cáustica a $4 \%$ poderia substituir com êxito a antiformina ${ }^{8,264}$. Além disso, conseguiu demonstrar que a incorporação da violeta de genciana (corante substituído, posteriormente, por verde de malaquita) aos meios de cultura, evitava ou freava o crescimento de bactérias contaminantes, sem atacar a flora específica ${ }^{8,110}$.

Bossan e Baudy, em 1922, e Lowenstein, em 1924, introduziram o uso do ácido sulfúrico (e outros ácidos) para a homogeneização e purificação (desinfecção da flora associada) do material designado para o cultivo ${ }^{8,110}$.

Corper e Stoner afirmaram, em 1946, que a solução de fosfato trissódico a $10 \%$ era tão eficaz como o hidróxido de sódio ou ácido oxálico na destruição da flora associada das amostras em que se investigava o bacilo tuberculoso ${ }^{8,110}$.

Lesslie, em 1959, comunicou que a incorporação do antibiótico actidione (cyclohexamida) aos meios de cultura na proporção de 1:2000, exercia um efeito micostático acentuado, frente à flora associada nos tecidos animais, especialmente nos órgãos internos e gânglios linfáticos dos bovinos ${ }^{8}$.

Em 1963, Kubica e colaboradores introduziram o uso de N-aceti-cisteína, um poderoso mucolítico e descontaminante derivado do aminoácido L-cisteína, para dissolver o muco e atacar a flora associada nos escarros, conteúdo gástrico e outras amostras destinadas ao cultivo dos bacilos da tuberculose ${ }^{8}$.

\subsection{3- INFECTIVIDADE}


A infectividade ou infecciosidade de um agente patogênico é sua habilidade de se alojar e se multiplicar em um hospedeiro. A medida básica da infectividade é o número mínimo de partículas infectantes necessárias para estabelecer uma infecção ${ }^{216}$.

Em humanos com tuberculose pulmonar, a infecciosidade para seus contatos está estreitamente relacionada ao número de bacilos presentes em seus escarros. Investigações realizadas na Holanda mostraram que pacientes tuberculosos com exame direto positivo para o escarro (baciloscopia positiva), infectaram 20,2\% dos contatos domiciliares, ao passo que os pacientes com baciloscopia negativa e cultura positiva, infectaram apenas $1,1 \%$ dos contatos familiares ${ }^{216}$.

É aceito, universalmente, que o indivíduo bacilífero com tuberculose pulmonar, ou seja, aquele que apresenta tosse vigorosa durante semanas ou meses, produzindo aerossóis viáveis em pequenas partículas e eliminando grande quantidade de bacilos, é o responsável pela maioria das transmissões da tuberculose na comunidade, infectando uma alta porcentagem de seus contatos ${ }^{216,257}$. Estima-se que os doentes bacilíferos excretam, aproximadamente, 10.000 bacilos por $\mathrm{ml}$ de escarro e que infectam de 4 a 5 contatos, antes de serem diagnosticados ${ }^{50,93}$.

Estudos demonstraram que uma pessoa com tuberculose pulmonar devida ao M.bovis, é tão contagiosa para seus contatos íntimos como uma pessoa com similar lesão pelo M.tuberculosis, apesar de, possivelmente, excretarem menos bacilos em seus escarros que pacientes infectados com cepas humanas ${ }^{68}$.

Quanto aos animais, trabalhos provenientes da Irlanda do Norte descrevem uma série de experimentos de infectividade em rebanhos bovinos, demonstrando que nas infecções naturais, o gado iniciou a excreção do M.bovis em 87 dias e que alguns casos ocorreram no gado negativo ao teste tuberculínico 199, 205, 206, 208, 216 . Em alguns rebanhos infectados artificialmente, por inoculação através da mucosa nasal, a excreção do M.bovis começou 7 dias após a inoculação ${ }^{199,216}$.

A transmissão da infecção de 2 rebanhos inoculados pela mucosa nasal a 2 outros rebanhos contatos, que foram introduzidos ao grupo 84 dias após a inoculação, 
não foi demonstrada. Assim, a infecciosidade do bovino tuberculoso para seus contatos, deve estar diretamente relacionada ao número de bacilos que ele excreta ${ }^{216}$.

Há uma grande incerteza a respeito da freqüência com a qual bovinos tuberculosos, especialmente aqueles animais que excretam pequeno número de bacilos em suas secreções nasais, detectáveis apenas pela inoculação em cobaio ou cultura, transmitam a infecção por M.bovis aos contatos animais ${ }^{205,216 .}$

Na Argentina, o M.bovis foi isolado de secreções nasais em meios de cultura, em $9(9,3 \%)$ das 97 vacas com teste tuberculínico positivo e com 5-10 anos de idade. Também na Argentina, o M.bovis foi isolado de swabs de secreção respiratória de 6 (30,0\%) das 20 cabeças de gado selecionadas em matadouros, que apresentavam lesões compatíveis com tuberculose $205,216$.

\subsection{4- VIRULÊNCIA}

O M.bovis tem um alto grau de virulência para humanos e bovinos, em contraste com o M.tuberculosis que é virulento para humanos mas não para o bovino $^{196,262}$.

Infelizmente, é relativamente pequeno o conhecimento de como esses organismos, que são destituídos de toxinas e cápsulas convencionais, sobrevivem em células equipadas com mecanismos bactericidas especializados. Apesar dos significativos avanços recentes, na elucidação das complexas estruturas químicas e genéticas da micobactéria, suas exatas funções na virulência e imunogenicidade permanecem obscuras ${ }^{71,208,209}$.

Os glicolipídios da parede celular das micobactérias, especialmente os sulfolipídios, devem contribuir para a virulência do bacilo, mas esta relação não é facilmente estabelecida. Os glicolipídios podem impedir a fusão lisossomofagossomo e talvez impedir a lise da bactéria nos fagócitos. Um sulfolipídio (6,6’dimicolato de trealose) denominado "fator corda", isolado de M.tuberculosis e M.bovis virulentos, possui ação tóxica e lesiva aos tecidos e foi considerado o 
principal fator de virulência dessas micobactérias por Middlebrook, Dubos e Pierce $^{53,71,223,228,236,240,262}$.

Este fator proporciona aos bacilos a faculdade de se reproduzirem nas culturas formando cordões serpiginosos, devido ao alinhamento paralelo das células bacterianas que resultam em uma formação semelhante a uma corda ${ }^{52,223}$.

Experimentalmente, a virulência de uma determinada cepa de bacilo da tuberculose pode ser quantificada, em termos de taxa de crescimento, no interior de pulmões de camundongos, cobaios ou macacos, inoculados por via aerógena. O crescimento do bacilo dependerá de numerosos fatores inespecíficos como a propensão genética do hospedeiro; a habilidade do bacilo em se multiplicar nos tecidos e induzir uma resposta imune no hospedeiro; o tamanho e a rota da infecção; a presença de infecções intercorrentes; e a existência de algumas formas de stress, como má nutrição, aglomeração ou terapia imunossupressora. Entretanto, é mínimo o conhecimento a respeito do modo de ação desses fatores de virulência nos hospedeiros humanos e animais domésticos e selvagens ${ }^{71,262}$.

\subsection{5- RESPOSTA IMUNOLÓGICA}

A resposta imune antituberculosa, frente aos três tipos de bacilos (M.tuberculosis, M.bovis e M.avium), é mediada pelo sistema imunológico celular timo-dependente, com uma população de linfócitos T sensibilizados, que ao reagirem com o antígeno específico liberam linfocinas capazes de produzir a reação cutânea, bem como de "ativar" os monócitos, tornando-os impróprios à multiplicação intracelular da micobactéria, entrando na lesão desenvolvida a partir da corrente sangüínea 34, 71, 93, 191, 201, 208, 209, 216, 228, 236, 262.

As células mononucleares, ao destruírem alguns corpos bacilares, apresentam os antígenos liberados aos linfócitos $\mathrm{T}$, freqüentemente por contato de superfície. Estes antígenos se combinam com receptores dos linfócitos que passam a liberar linfocinas específicas que, como mediadoras, ativam os macrófagos contra o bacilo da tuberculose, para fagocitá-los rapidamente e destruí-los. Estabelece-se desse modo 
um ciclo interdependente: bactéria (antígeno) - macrófago - linfócito T - linfocina macrófago - bactéria. Os macrófagos ativados pelas linfocinas adquirem capacidade destruidora de amplo espectro ${ }^{228,236}$.

São várias as linfocinas secretadas pelos linfócitos e de interesse para a imunidade antituberculosa, destacando-se:

- Interleucina 2, que induz a quimiotaxia e a proliferação de outros linfócitos T, amplificando a resposta imunológica.

- Fator de inibição da migração de macrófagos, que aumenta a viscosidade da membrana dos macrófagos, fixando-os nos locais da agressão bacilar.

- Fator de ativação de macrófagos, que induz transformações morfológicas nos macrófagos, tornando-os mais competentes na sua função de fagocitar e de destruir aquilo que fagocitam, fazendo com que se organizem em granulomas e levando-os a secretarem diversas substâncias, dentre as quais enzimas líticas e fator de ativação de fibroblastos.

- Fator de inibição da multiplicação bacilar, que induz o macrófago a inibir a multiplicação do bacilo fagocitado que permanecerá viável, mas quiescente.

- Fator de transferência, capaz de transferir a ação imunológica das células quando transpostas para outro organismo.

- Fator de transformação dos leucócitos - ativa os linfócitos T normais transformando-os em células blásticas, multiplicando assim a produção de leucinas.

- Fator estimulador de colônias - favorece a multiplicação bacilar e parece estar relacionado com a alergia tuberculosa ${ }^{191,236}$.

Dependendo da linfocina liberada pelos linfócitos T, os macrófagos ativados imunológicamente podem destruir o bacilo ou induzir a bacteriostase (o bacilo permanece viável dentro da célula, mas sem se multiplicar) persistente, a qual é usualmente suficiente para proteger o hospedeiro. Entretanto, essa bacteriostase não 
elimina totalmente a infecção, permitindo que a reativação ocorra a qualquer momento, se as defesas celulares se esgotarem ${ }^{216,257 .}$

Se os macrófagos não desenvolverem poder suficiente para matar o bacilo da tuberculose, este se multiplicará e a doença progredirá, resultando na formação do granuloma, na necrose de caseificação e na fibrose, elementos patológicos típicos da lesão tuberculosa. Esses elementos estarão ausentes quando a depressão dos linfócitos $\mathrm{T}$ for total, como no caso da AIDS, onde, além da imunidade, a hipersensibilidade também não se manifesta ${ }^{191,228}$.

Imunidade e alergia desenvolvem-se simultaneamente na infecção tuberculosa, e isso foi já demonstrado por Koch ${ }^{236}$. A alergia tuberculínica (hipersensibilidade) pode ser considerada como um índice de imunidade. As crianças, nas grandes cidades, e os adultos, nas populações indenes à tuberculose, que não possuem alergia tuberculínica, mostram receptividade muito maior que a dos indivíduos alérgicos, ao serem expostos ao contágio virulento. Particularmente elucidativas a este respeito, são as observações feitas por Heimbeck, na Alemanha, em moças que entraram em escolas de enfermagem, indo trabalhar mais tarde nos hospitais: aquelas que apresentavam reação negativa à tuberculina contraíam a tuberculose com muito maior freqüência do que as que já reagiam positivamente ao ingressar na escola ${ }^{34}$.

Observações no mesmo sentido foram feitas durante a guerra de 1914-1918 em soldados africanos tuberculina-negativos enviados à França e entre os quais a mortalidade por tuberculose foi muito maior que nas tropas européias, tomando a doença um curso agudo (pneumonia tuberculosa aguda), ao invés do quadro consuntivo habitual do adulto alérgico ${ }^{34}$. Os indivíduos tuberculina-positivos têm maior resistência aos contágios, não porque são sensíveis à tubérculo-proteína, e sim porque, simultaneamente, têm imunidade ${ }^{236}$.

A aquisição da primo-infecção confere ao indivíduo imunidade relativa contra a reinfecção tuberculosa ${ }^{34}$. Algumas pesquisas realizadas em regiões com alta prevalência de tuberculose por M.bovis em bovinos demonstraram que, embora o número de pessoas reatoras à tuberculina aumentava de acordo com o aumento na 
incidência de infecção por M.bovis em rebanhos bovinos, as taxas de morbidade e mortalidade por tuberculose humana devida ao M.tuberculosis diminuíam na mesma população. Estas observações levaram os cientistas a concluírem que a infecção por M.bovis protegia contra uma subsequente infecção por M.tuberculosis e que, provavelmente, o M.bovis conferia alguma imunidade contra a reinfecção com cepas homólogas, como indicou o sucesso da vacinação $\mathrm{BCG}^{92}$.

Portanto, os dados acumulados sobre a imunidade na tuberculose, sintetizados nos seus aspectos fundamentais, são: anticorpos humorais não desempenham nenhum papel no processo de defesa; a imunidade é mediada por células; antígenos bacilares apresentados pelos macrófagos aos linfócitos $\mathrm{T}$ provocam nestes a liberação de linfocinas, que por sua vez ativam aqueles a fagocitar e matar o bacilo da tuberculose; linfócitos $\mathrm{T}$ mantêm a memória específica para respostas de defesa quando o organismo é novamente agredido pelo bacilo da tuberculose ${ }^{236}$.

O fato de a imunidade antituberculosa ser mediada por células atrasou por quase um século o seu melhor conhecimento, devido à ausência de técnicas de culturas de células. Por isso, não havia meios de avaliar a imunidade, como se podia medir a alergia, graças à tuberculina ${ }^{236}$.

\subsection{6- SUSCEPTIBILIDADE}

O homem é tão susceptível ao M.bovis quanto ao M.tuberculosis, sendo o bacilo bovino tão patogênico para o ser humano quanto o bacilo humano $228,236,237,257,272,281$.

Historicamente, a susceptibilidade do homem ao bacilo da tuberculose devese ao fato de que em todas as regiões aonde a civilização chegou trazendo consigo o M.tuberculosis, a tuberculose se propagou rapidamente com elevada mortalidade, porque as populações indenes da infecção não tinham defesas específicas. Face à agressão do bacilo, durante algumas gerações processou-se uma seleção natural de indivíduos mais resistentes, adquirindo a doença um caráter endêmico ${ }^{236}$. 
Uma maior resistência à tuberculose em certos grupos étnicos pode ser o resultado de um processo de seleção natural através da morte precoce dos constitucionalmente fracos ou linhagens familiares não resistentes nos povos primitivos; não sendo apropriado falar em susceptibilidade natural da raça, o que significaria uma constante, definida e transmissível susceptibilidade ${ }^{216}$. Não existem provas da existência de hereditariedade da doença e a tuberculose congênita é raríssima ${ }^{236}$. Existem, contudo, algumas evidências de variações na susceptibilidade racial com respeito a infecção, doença clínica e taxas de mortalidade ${ }^{216}$.

A raça judia é a mais resistente e a raça negra a mais susceptível à doença clínica e morte pelo M.tuberculosis. A chance de um homem negro tornar-se tuberculoso em um dado ambiente não é maior que a de um homem branco, mas a chance do homem negro vir a morrer de tuberculose, é 3 vezes maior ${ }^{216}$.

Muito se falou sobre a maior susceptibilidade dos negros à tuberculose e, nos Estados Unidos, Pinner relatou que neles as lesões tuberculosas são mais invasivas e mais severas. Essa susceptibilidade genética foi questionada com a argumentação de que a raça negra, historicamente, foi agredida pela tuberculose muito depois que a raça branca e não teve tempo de sofrer uma seleção natural de organismos mais resistentes. Outro agravante para os negros são as suas condições sócio-econômicas desfavoráveis. Até 1990, a baixa prevalência da infecção tuberculosa na população norte-americana sofria exceção entre os negros, sobretudo nos que viviam em maior promiscuidade e situações de miséria ${ }^{236}$.

Nos Estados Unidos, membros da raça judia não tinham resistência aumentada à infecção tuberculosa, mas tinham uma resistência definida à doença ${ }^{216}$. Constatou-se de longa data, que os judeus eram mais resistentes à tuberculose, mas essa verificação foi baseada nos judeus ashkenasis (Europa Central), que desde a Idade Média viveram confinados nos guetos, casando entre si. Vitimados em grande proporção pela tuberculose, os mais fortes geraram descendentes mais resistentes, havendo assim, uma seleção natural. Com a fundação de Israel, os judeus que ficaram tuberculosos nos campos de concentração nazistas foram para lá levados ao mesmo tempo que os judeus iemenitas que viveram isolados nos desertos, por milênios. 
Estes, em contato com aqueles, rapidamente se contagiaram e muitos desenvolveram primo-infecções graves. Ficou assim comprovado que a resistência à tuberculose, dos judeus da Europa, não é baseada em uma característica genética geral dos israelitas e sim em uma circunstância histórico-social. Os judeus iemenitas não apresentaram nenhuma resistência natural à tuberculose ${ }^{236}$.

Em uma revisão da literatura, concluiu-se que em condições adversas de uma guerra, há um aumento da morbidade e mortalidade na população civil afetada, presumivelmente, devido à reativação de uma prévia infecção tuberculosa, causada pela diminuição na disponibilidade de serviços médicos, falta de abrigo, e queda na ingestão calórica ${ }^{216}$.

As crianças são mais susceptíveis ao M.bovis quando consomem leite cru proveniente de vacas tuberculosas, mesmo quando infectadas com pequeno número de bacilos ${ }^{196}$. Os adultos mais susceptíveis ao M.bovis, são aqueles expostos ocupacionalmente ao bovino tuberculoso, infectando-se pela via aerógena ou pelo consumo de leite ou produtos lácteos não fervidos ou pasteurizados $42,48,57,91,93,104$, 127, 148, 160, 175, 196, 201, 217, 228, 237, 259, 295, 296 . A exploração leiteira é o setor de maior risco para o homem, devido ao estreito contato do ordenhador e seus familiares com os animais, em repetidas ocasiões, diariamente ${ }^{74}$.

A reativação de antigos focos primários de infecção, com conseqüente doença clínica em humanos, pode ser desencadeada pela imunodepressão resultante da idade avançada, infecções e doenças intercorrentes, deficiência nutricional e uma vida estressante $^{216}$.

Estudos epidemiológicos indicaram que pessoas infectadas pelo M.bovis têm menor probabilidade de desenvolver a doença pós-primária tardiamente do que aqueles infectados pelo M.tuberculosis, mas não está claro, se isto é resultado de diferenças na rota predominante da infecção, ou de diferenças na susceptibilidade do hospedeiro $295,296$.

A susceptibilidade de certas espécies animais aos diferentes tipos de bacilos da tuberculose é muito variável e depende da carga infectante e da susceptibilidade 
do hospedeiro; sendo que a susceptibilidade, por sua vez, depende de fatores como a constituição genética, a exposição prévia ao Mycobacterium sp., estado nutricional, status social no rebanho, stress durante o manejo e fatores endócrinos ${ }^{199}$.

Por exemplo, o bovino é susceptível ao M.bovis, mas relativamente resistente à infecção pelo M.tuberculosis. Além disso, animais de laboratório, como cobaios e coelhos, são susceptíveis ao M.bovis, ao passo que galinhas são resistentes, provavelmente devido à sua maior temperatura corporal ${ }^{262}$.

As vacas leiteiras apresentam uma maior susceptibilidade à tuberculose bovina. As principais causas dessa susceptibilidade maior são o stress e a manutenção de animais de maior idade para a produção láctea. Este fato não ocorre no gado de corte, que se mantém por menos tempo em criações extensivas, sendo menor o contato entre animais e homens ${ }^{74}$.

A origem e o status taxonômico do gado domesticado, o qual historicamente tem sido o principal reservatório e hospedeiro do Mycobacterium bovis, é controversa ${ }^{216}$. As raças zebu e taurina são diferenciadas primariamente pela presença ou ausência de corcova e reconhecidas como espécies separadas (Bos indicus e Bos taurus). Suspeita-se que o gado tipo zebu indiano e africano é muito mais resistente à tuberculose que o gado europeu, e os efeitos da doença nesse gado são menos severos 199, 216. Entretanto, não existem estudos conclusivos a esse respeito ${ }^{199}$.

Suspeita-se também que o bovino, no inverno da Nova Zelândia e Irlanda, sob condições nutricionais deficientes em minerais, devido ao pasto insuficiente em altas montanhas, tem sofrido um aumento da susceptibilidade à infecção e doença clínica pelo M.bovis ${ }^{216}$.

Na Austrália do Norte, a imunodepressão do bovino domesticado, indicada pela baixa sensibilidade à tuberculina, tem sido associada com subnutrição, resultando em severa perda de peso combinada com os efeitos do stress, devido à reunião de tropas com gado semi-selvagem na estação seca ${ }^{216}$.

Texugos europeus e gambás australianos são naturalmente susceptíveis ao 
M.bovis, e reservatórios endêmicos da infecção 24, 47, 58, 61, 63, 64, 68, 69, 70, 100, 125, 149, 151, 173, 178, 180, 199, 208, 210, 216, 228, 268, 269, 297 . Acredita-se que a susceptibilidade dos texugos à tuberculose, é devida a uma fraca resposta imunológica quando comparados a outras espécies animais ${ }^{149,210 .}$

A susceptibilidade do gambá australiano à infecção por M.bovis, foi demonstrada em 1948 por Bolliger e Bolliger, que mantiveram um gambá em contato com animais infectados experimentalmente, e observaram que ele havia contraído tuberculose pulmonar, morrendo algum tempo depois ${ }^{105}$. Entretanto, o gambá brasileiro é resistente à infecção natural da tuberculose 167.

O cervo da raça "red" e espécie Cervus elaphus, e o alce da espécie Cervus canadensis, que têm sido domesticados e criados intensivamente em fazendas na Nova Zelândia, são naturalmente susceptíveis à tuberculose causada pelo M.bovis ${ }^{133}$. Os cervos dessa raça foram considerados menos resistentes ao M.bovis do que os bovinos, por causa de sua tendência para a formação de abscessos, no lugar do granuloma clássico ${ }^{61} \mathrm{e}$, portanto, mais infeccioso para outras espécies animais que o bovino $^{199}$.

Em cervos de criação não totalmente domesticados, o stress do manejo, o confinamento e uma nutrição inadequada, foram apontados como causas do aumento da susceptibilidade do animal à infecção e do desenvolvimento de doença, devido a uma imunidade comprometida ${ }^{61}$.

O macaco é igualmente susceptível à infecção por M.tuberculosis e M.bovis, e há poucas dúvidas de que o macaco em cativeiro é o mais susceptível de todos os animais à tuberculose ${ }^{137,173,216,261}$.

A tuberculose é um problema comum em primatas não humanos cativos, e macacos da espécie "Novo Mundo" eram considerados mais resistentes à doença do que os macacos da espécie "Velho Mundo", por possuírem uma enzima que aumentava a defesa dos macrófagos contra o bacilo da tuberculose ${ }^{216,256}$. Entretanto, a ocorrência de tuberculose em símios da fauna indígena, tem levantado dúvidas a respeito de diferenças na susceptibilidade entre essas duas espécies de primatas ${ }^{99}$. 
O suíno é susceptível aos 3 tipos de bacilos da tuberculose 48, 135, 245, 261, 272. Entretanto, existem algumas evidências, de que porcos mais velhos são considerados mais resistentes que porcos mais jovens à infecção por M.bovis, porque estes apresentam uma maior tendência à generalização do processo ${ }^{216}$.

Cachorros e gatos são susceptíveis à infecções por M.bovis e M.tuberculosis, mas são relativamente resistentes à infecção pelo M.avium ${ }^{131,137}$.

Estudos indicaram que as cabras são susceptíveis ao M.bovis, mas, freqüentemente, resistentes ao M.tuberculosis ${ }^{137,}{ }^{216}$. Os carneiros são pouco susceptíveis à tuberculose ${ }^{181}$.

O cavalo é naturalmente susceptível aos 3 tipos de bacilos da tuberculose (M.tuberculosis, M.bovis e M.avium) ${ }^{136,199,216,261 .}$

\subsection{7- RESISTÊNCIA}

\section{a) Meio Ambiente}

Apesar do M.bovis ser considerado um patógeno intracelular obrigatório, evidências experimentais mostram que ele pode sobreviver fora de um hospedeiro animal, no meio ambiente, por longos períodos de tempo (acima de 2 anos) sob condições favoráveis. Esta habilidade foi demonstrada em estudos observacionais da sobrevivência do bacilo, após contaminação natural ou artificial ${ }^{103,199}$.

Acredita-se que a elevada resistência do M. bovis e das outras micobactérias ao meio ambiente seja atribuída ao alto teor de lipídios da parede bacteriana $^{74,92,108,125,201,228,237,272}$. A hidrofobicidade desses lipídios pode ter um papel importante na resistência à desidratação, e garantindo a sobrevivência desses organismos sob condições adversas ${ }^{228}$. O M.tuberculosis, por exemplo, sobrevive durante 6 a 8 meses no escarro, ao abrigo da luz solar, e as partículas contaminadas em suspensão no ar podem manter-se infectantes durante 10 dias $^{301}$.

Uma adequada disponibilidade de nutriente como matéria orgânica, é o fator 
mais importante para a sobrevivência desses organismos, pois se os nutrientes forem escassos, os organismos tornam-se mais susceptíveis aos efeitos adversos de uma elevação na temperatura, capaz de ocasionar a morte bacteriana ${ }^{199}$. Outros fatores que influenciam são: pH, umidade, exposição à luz solar e luz ultravioleta ${ }^{199,} 228$.

No bovino infectado naturalmente pelo trato respiratório, foi possível detectar o M.bovis no muco nasal durante aproximadamente 80 a 100 dias após a infecção ${ }^{205,206,208}$. No muco traqueal, o bacilo da tuberculose bovina pode permanecer vivo por 30 a 40 dias. No leite acidificado sobrevive por 15 dias. Na manteiga doce e cremosa se mantém por 4 semanas, enquanto que na manteiga ácida e salgada (4-6\% de $\mathrm{NaCl}$ ) morre em 5 a 10 dias, sobrevivendo, excepcionalmente, por $45 \operatorname{dias}^{237}$.

Wray, em 1975, reviu os fatores que influenciavam a sobrevivência ambiental de bactérias patogênicas em geral, e particularmente do M.bovis ${ }^{199,216}$.

Os experimentos que Maddock realizou no sul da Inglaterra no período de 1916 a 1920, demonstraram que a luz solar direta matava o bacilo em culturas e que os bacilos presentes no pus e secreções de abcessos permaneciam viáveis por várias semanas 2, 103, 216. Em estrume líquido, artificialmente contaminado com 5.000 bacilos, provenientes de tecidos de bovinos tuberculosos e estocados em um jarro sob a terra, foi encontrado M.bovis vivo e virulento por, no mínimo, 4 meses após a infecção. Durante esse tempo, houve uma diminuição gradual na virulência do material ${ }^{289}$. Em estábulos, ao abrigo da luz, sobreviviam por vários meses em grandes expectorações, e em gotículas de 3 a 18 dias ${ }^{201}$. Em água artificialmente contaminada, o bacilo sobreviveu por mais de 10 semanas $^{2}$.

Willians e Hoy, em 1930, também no sul da Inglaterra, constataram que sob condições naturais o M.bovis permaneceu vivo e virulento em fezes de vacas expostas nos pastos, por pelo menos 5 meses durante o inverno, por 2 meses durante a primavera e 4 meses durante o outono. No verão, não foram encontrados bacilos vivos após 2 meses 2, 103, 180, 199, 216, 289 . Sob condições especiais, isto é, em fezes protegidas da luz solar direta, o período de sobrevivência do M.bovis foi de 4 meses durante o verão, e no outono, protegidas da ação de insetos e minhocas, o bacilo permaneceu viável após 6 meses ${ }^{199,289}$. As fezes de vacas, expostas no pasto, estão 
sujeitas não apenas à degradação pelo calor (luz solar), ar e chuva, mas também à ação de insetos e minhocas e de outra bactéria, protozoário ou fungo, os quais normalmente contribuem para a destruição do bacilo da tuberculose ${ }^{216,289}$. Em fezes naturalmente infectadas e armazenadas em jarros protegidos de insetos no escuro, o M.bovis foi encontrado após 12 meses e por um período de pelo menos 2 anos em fezes artificialmente infectadas e estocadas sob as mesmas condições ${ }^{289}$.

Em 1932, Maddock demonstrou ainda que o M.bovis em capim crescido, tratado com uma fina emulsão de pulmões de bovinos tuberculosos contendo uma estimativa de 120 milhões $\left(1,2 \times 10^{8}\right)$ bacilos virulentos vivos por pé quadrado (cerca de $30,48 \mathrm{~cm}^{2}$ ), permaneceu viável e virulento por, pelo menos, 49 dias no verão. Em pedaços de pastos similarmente tratados com 1.2 milhões $\left(1,2 \times 10^{6}\right)$ e 120.000 $\left(1,2 \times 10^{5}\right)$ bacilos por pé quadrado, o tempo de sobrevivência do M.bovis foi de 28 e 14 dias, respectivamente $2,182,199,216,289$.

Genov, em 1965, misturou M.avium, M.bovis e M.tuberculosis com fezes, sangue e urina, e observou que as micobactérias sobreviveram por 150 a 332 dias a $12-24^{\circ} \mathrm{C}$ e protegidas da luz solar direta. Quando expostas à luz solar e temperaturas de 24 a $34^{\circ} \mathrm{C}$, o tempo de sobrevivência foi de apenas 18 a 31 dias. Quando enterradas em solo sombreado e a uma profundidade de $5 \mathrm{~cm}$, elas sobreviveram por mais de 2 anos, mas apenas por 11 a 12 meses a uma profundidade de $1 \mathrm{~cm}$. Em um recipiente com água não contaminada a 18 a $24^{\circ} \mathrm{C}$, o M.bovis sobreviveu por 236 dias, mas a adição de fezes e urina à água aumentou a sobrevivência para 452 e 469 dias, respectivamente ${ }^{103,199,272}$.

A sobrevivência do M.bovis sob condições australianas, onde a temperatura ambiente é muito mais alta e por maiores períodos de tempo que na Europa, foi determinada pela inoculação artificial de fezes de bovinos com M.bovis em solo seco e úmido, em um estudo realizado por Duffield e Young em 1985. O M.bovis sobreviveu por 4 semanas nestes solos sob $80 \%$ de sombra e estocado no laboratório, no escuro. Não houve recuperação do M.bovis em 4 semanas, das fezes ou solo quando expostos à luz solar sob qualquer condição ${ }^{103,199,216 .}$

Estes estudos sugeriram que, quando o M.bovis foi depositado artificialmente 
em fezes, solos e outros materiais estéreis e mantido fora da luz, pôde sobreviver por muitos meses, e sob condições ambientais naturais morreu mais rapidamente ${ }^{199,216}$. Permitiram também constatar que a dose mínima infectante de bacilos para que ocorra uma infecção oral é alta, e por isso a importância das fômites como uma fonte de infecção em muitos ambientes parece ser pequena, quando comparada com outros mecanismos de transmissão, e certamente menor do que é comumente sugerida ${ }^{199}$.

Um estudo realizado em 1979 por Anon, na Inglaterra, em secreções e excreções de texugos depositadas no pasto durante períodos de tempo variáveis, demonstrou que o M.bovis sobreviveu na urina por 3 dias no verão e 28 dias no inverno; no escarro por 7 e 70 dias, respectivamente, e em fezes naturalmente infectadas por 14 e 28 dias ${ }^{199,210,216 .}$

Livingstone em 1979, concluiu que a decomposição de uma carcaça de texugo é capaz de destruir o M.bovis. Outro estudo demonstrou que, em uma carcaça deixada no pasto, o nível de infecção havia caído após 2 semanas, sendo que depois de 4 semanas o M.bovis não pode ser recuperado. Em 3 carcaças de texugos queimadas, o M.bovis não pode ser recuperado após 2,3 e 6 semanas, respectivamente ${ }^{199,210,216}$.

\section{b) Desinfetantes}

O M.bovis e outras micobactérias são resistentes à diversos desinfetantes químicos, com exceção dos produtos que desnaturam proteínas como o fenol, formol, cresol e álcool 2, 92, 125, 201, 237, 272. A resistência da micobactéria aos desinfetantes é uma característica importante, porque limita o tipo de desinfecção ativa contra o organismo, prejudicando o seu combate no meio ambiente ${ }^{191,192,228 .}$

A desinfecção visa a destruição dos microrganismos em objetos inanimados, e desinfetantes são as substâncias usadas para a destruição de bactérias ou outros microrganismos invasores 225 .

Em 1876, Robert Koch estabeleceu a etiologia bacteriana das doenças infecciosas, e desde então, os desinfetantes químicos passaram a ter um importante papel na prevenção das doenças ${ }^{224}$. 
Dentre os fatores que podem modificar a eficiência dos desinfetantes químicos, merecem destaque especial a concentração do desinfetante, a temperatura (perdem sua efetividade a $0^{\circ} \mathrm{C}$ ), o $\mathrm{pH}$ ambiental, a dureza da água, o tipo de microrganismo e a presença de matéria orgânica ${ }^{224}$.

A resistência das bactérias álcool-ácido resistentes aos desinfetantes, é considerada como sendo intermediária, entre as bactérias na forma vegetativa e os esporos bacterianos, estando relacionada à composição da parede celular destes microrganismos $224,225,301$.

No âmbito dos desinfetantes químicos com atividade sobre as micobactérias, os estudos realizados destacaram a eficácia dos produtos cujo mecanismo de ação é representado pela desnaturação das proteínas microbianas. Neste particular, os compostos fenólicos, o formaldeído, o glutaraldeído, os compostos clorados, o iodo e os iodóforos têm sido os mais eficazes ${ }^{224}$.

Os álcoois etílico e isopropílico são geralmente aceitos como excelentes agentes micobactericidas, na concentração de $50 \%$ em soluções aquosas. O efeito germicida do álcool é potencializado pela adição de outros agentes, tais como, iodo e formaldeído. As soluções contendo $70 \%$ de álcool e $8 \%$ de formaldeído permitem um alto nível de atividade. A grande desvantagem dos álcoois, é que são inativados na presença de matéria orgânica (fezes, urina, sangue, leite, e outros) ${ }^{224}$.

O fenol ou ácido carboxílico é um dos mais antigos germicidas e sua eficácia foi demonstrada por Lister em 1867. Como grupo, os fenóis e os cresóis, particularmente os compostos à base de orto-fenilfenol, em solução a 1:200, têm uma eficiente ação sobre as micobactérias. São considerados estáveis e não são inativados pelo sabão, nem pela matéria orgânica, razão pela qual têm sido considerados como desinfetantes de escolha para a desinfecção de superfícies com contaminação fecal. Entretanto, possuem ação corrosiva e são irritantes ao contato com a pele ${ }^{224}$.

O mecanismo de ação dos compostos fenólicos baseia-se no fato de que, em altas concentrações atuam no citoplasma celular, destruindo a parede da célula e precipitando as proteínas, porém, em concentrações mais baixas, a eventual morte da 
célula bacteriana é obtida pela inativação do seu sistema enzimático essencial ${ }^{224}$. No grupo dos aldeídos, os produtos com ação germicida mais estudados são: o formaldeído e o glutaraldeído ${ }^{225}$.

O formaldeído é um gás, fornecido no mercado em soluções aquosas de 37 a $40 \%$, com o nome de formalina. Esta solução é estabilizada pela adição de 8 a $15 \%$ de metanol ou etanol, para retardar a polimerização; é eficaz contra bactérias, fungos e vírus, mas sua ação é lenta. Na concentração mínima de $8 \%$, apresenta atividade micobactericida; em solução a 8\%, em isopropanol ou etanol a 70\%, é utilizado para esterilizar escarro de tuberculosos. Em concentrações altas também precipita proteínas e as soluções de formaldeído liberam um gás irritante e tóxico ${ }^{224}$.

O glutaraldeído possui uma atividade esporocida 2 a 8 vezes superior à apresentada pelo formaldeído, não sendo corrosivo e irritante, apesar de também ser tóxico. Quando alcalinizado, em solução aquosa a 2\%, apresenta grande atividade bactericida e esporocida, exercendo uma ação tóxica sobre as células bacterianas $^{224,225}$.

Os compostos clorados pertencem a outro grupo de desinfetantes de comprovada ação micobactericida. Nas concentrações de 0,1 a $0,5 \%$ de cloro ativo, possuem atividade intermediária ${ }^{224}$.

Um grande número de compostos clorados está disponível no mercado e, basicamente, subdividem-se em cloro líquido, compostos clorados inorgânicos (hipoclorito de sódio, cálcio e lítio; fosfato trisódico clorado) e os orgânicos (ácido tricloroisocianúrico, dicloroisocianurato de sódio hidratado e dicloroisocianurato de sódio ou potássio anidro) ${ }^{224,225}$.

O efeito bactericida do cloro é produzido pela inibição de alguns sistemas enzimáticos essenciais e se realiza em duas fases: na primeira, há a penetração do componente germicida ativo do desinfetante na parede da célula bacteriana, e na segunda fase, ocorre uma reação química com o protoplasma da célula, formando complexos tóxicos que destroem o microrganismo ${ }^{224,225}$. Na presença de matéria orgânica, o cloro reage com as partículas protéicas e forma cloraminas que 
conservam parte de sua atividade bactericida, no entanto, os níveis de cloro ativo são consideravelmente reduzidos ${ }^{225}$. Os compostos clorados exercem uma ação corrosiva nas superfícies expostas a eles ${ }^{224}$.

O iodo e os iodóforos são, também, considerados agentes efetivos sobre o bacilo da tuberculose. O iodo é potente e de rápida ação, sendo que na ausência de matéria orgânica, a maioria das bactérias expostas a uma solução de iodo a 1:20.000 é destruída em um minuto ${ }^{224}$.

De acordo com a literatura, podem-se empregar como desinfetantes nos laboratórios e outros locais contaminados, soluções de fenol a 5\%, cresol a $3 \%$ ou $5 \%$, formaldeído de 3 a $8 \%$, hipoclorito de sódio a $1 \%$ e glutaraldeído a $2 \%^{52,192,201,225,237,301}$. O glutaraldeído a $2 \%$ é recomendado para a desinfecção de endoscópios $^{225}$.

Em 1984, a OMS descreveu a descontaminação de diversos materiais que estiveram em contato com micobactérias, através do emprego da cloramina a $5 \%{ }^{225}$.

Os compostos de amônia quaternária, como, por exemplo, o cloreto de benzalcônio (Zephiran), não devem ser usados como bactericidas ${ }^{52,301}$.

As micobactérias são resistentes a ação de agentes químicos, mas sensíveis a ação de agentes físicos, como a radiação ultravioleta e ao calor ${ }^{2,191,192 .}$

\section{c) Medicamentos}

As micobactérias são relativamente resistentes a muitos dos antibióticos de largo espectro, com a notável exceção da estreptomicina e rifampicina. Muitos agentes antimicrobianos usados para tratar infecções pelo M.tuberculosis e M.bovis, como a isoniazida, etambutol e outros, e que são específicos para esses bacilos, freqüentemente demonstram pouca ação inibitória contra outras espécies de micobactérias ${ }^{32}$. O M.bovis é naturalmente resistente à pirazinamida, que é uma das principais drogas antituberculosas $74,92,108,125,201,237,272$. 
Em uma população bacteriana numerosa, haverá sempre germes naturalmente resistentes às diferentes drogas antituberculosas. A esta condição, geneticamente determinada e independente de uma exposição prévia à droga, dá-se o nome de resistência natural $53,93,153,191,236$. Assim, por exemplo, numa população de um bilhão de bacilos haverá cerca de 10 mil bacilos naturalmente resistentes à isoniazida $^{191}$.

A utilização incorreta das drogas ou a utilização de apenas uma droga (monoterapia) é responsável pela seleção e multiplicação de germes resistentes a essa mesma droga, fato a que se dá o nome de resistência adquirida 53, 93, 191, 192, 230, 236. Como o tratamento é longo e a população bacteriana elevada, as células mutantes resistentes vão se multiplicando até se tornarem a maioria ${ }^{93,191,192 .}$

Habitualmente, o tratamento antituberculose é feito sem que se conheça a sensibilidade do bacilo infectante em relação às drogas empregadas. Assim, para evitar o surgimento de resistência bacteriana adquirida, no início do tratamento devese empregar associadamente mais de uma droga. A isoniazida, rifampicina, etambutol e estreptomicina, nesta ordem, são drogas capazes de impedir a seleção de mutantes resistentes ${ }^{191}$. Em um esquema duplo, havendo resistência primária a uma das drogas, apenas a outra será totalmente ativa, fato que irá determinar a seleção de mutantes resistentes. Para não permitir que isto aconteça, na fase inicial do tratamento é necessário o uso de esquema tríplice ${ }^{93,191,236 .}$

Para fins epidemiológicos, quando um paciente, portador de germes resistentes (resistência adquirida), infecta um indivíduo sadio e este adoece, sua lesão será colonizada por bacilos resistentes às drogas que esse segundo paciente ainda não tomou, e diz-se que esse caso apresenta resistência primária ${ }^{53,93,191,192,236 .}$

O conhecimento da resistência primária permite avaliar a qualidade do programa de controle da tuberculose em um país, e possibilita a modificação de esquemas terapêuticos vigentes ${ }^{93,192}$.

A distribuição da resistência primária não é homogênea. Em grupos menos cooperantes com o tratamento, as taxas de resistência podem ser mais elevadas que a 
média nacional. Nos países onde a tuberculose está sob controle, a resistência primária não ultrapassa $5 \% .^{93,192}$. No Brasil, a taxa média observada desde a década de 60 sempre foi superior a 10\% e no último período estudado (1986 a 1988) foi de $15 \%{ }^{192}$.

Em um estudo realizado na Argentina em 1974, Kantor e Lesslie determinaram a proporção de mutantes resistentes às drogas isoniazida, rifampicina, etambutol e cicloserina, em cepas selvagens de M.bovis e M.tuberculosis. Em relação à isoniazida, ambas as espécies se comportaram de maneira semelhante. Frente à rifampicina, etambutol e cicloserina, o M.tuberculosis apresentou maior proporção de mutantes resistentes espontâneos que o M.bovis. Concluíram que, de acordo com os mecanismos de desenvolvimento de resistência em tuberculose, havia uma menor probabilidade de aquisição de resistência nos pacientes infectados por M.bovis e tratados com essas drogas ${ }^{153}$.

\section{3- PATOGENIA}

\subsection{1- PORTA DE ENTRADA}

No homem o M.bovis pode determinar as mesmas formas clínicas e lesões patológicas que o M.tuberculosis. Anteriormente aos programas de controle da tuberculose no bovino e à obrigatoriedade da pasteurização do leite, as formas mais comuns causadas pelo M.bovis eram as extrapulmonares, sendo a tuberculose renal (infecção do trato gênito-urinário) nos adultos, e a tuberculose ganglionar em crianças as mais freqüentes manifestações, devido ao mecanismo de transmissão através do trato gastrointestinal, pela ingestão de leite ou produtos lácteos não fervidos ou não pasteurizados $4,74,89,92,125,142,148,160,163,201,228,236,272$. Posteriormente, houve uma crescente importância da infecção por M.bovis adquirida pela inalação do bacilo, principalmente em pessoas que trabalhavam diretamente com bovinos tuberculosos ${ }^{110,266}$.

Portanto, a porta principal de entrada do bacilo da tuberculose é o alvéolo pulmonar, sendo de importância secundária a penetração pela via digestiva ${ }^{34}$. Para 
que uma pessoa se torne infectada, deve ser inalado mais que um bacilo da tuberculose, estimando-se uma variação de 3 a 300 bacilos ${ }^{216}$. Quando um indivíduo recebe uma carga infecciosa de bacilos da tuberculose pela primeira vez (primoinfecção) de um doente de tuberculose pulmonar ou de um bovino tuberculoso, e os bacilos alcançam a periferia do pulmão, eles vencem as defesas da árvore brônquica e localizam-se nos alvéolos da periferia pulmonar, onde provocam reação inflamatória exsudativa de tipo inespecífico 34, 111, 191, 223, 236, 237, 257, 299. Em um período de aproximadamente 15 dias, os bacilos podem multiplicar-se facilmente porque não existe imunidade adquirida. Sabendo-se que a divisão bacilar é binária e ocorre, em média, a cada 18 a 20 horas, ao fim de 15 dias os bacilos podem atingir um número superior a $10^{5}$ e partindo da lesão pulmonar, por via linfohematogênica, comprometem os linfonodos e órgãos dos diversos sistemas e aparelhos, principalmente o fígado, o baço, a medula óssea, os rins, os ossos, intestinos, ovário, testículos e o sistema nervoso. Essa disseminação, entretanto, é "benígna", de poucos bacilos, que ficarão latentes ou serão destruídos pela ação da imunidade que se instalará $^{34,111,160,191,196,223,236,237,257}$. É importante ressaltar que a disseminação e a latência são o que explicam a "porta de entrada" para as formas extrapulmonares da tuberculose ${ }^{191}$.

No início da terceira semana, o organismo irá mobilizar seu sistema de defesa imunológico específico iniciando um processo proliferativo com formação do tubérculo, constituído essencialmente de células histiocitárias, células gigantes tipo Langhan e células epitelióides em volta, havendo mais na periferia uma barreira leucocitária 34, 208, 236 .

O tubérculo pode encapsular-se e no local da inoculação inicial, no pulmão, haverá um foco pequeno, arredondado, de 1 a $2 \mathrm{~mm}$, esbranquiçado, de consistência amolecida e constituído principalmente por material caseoso, denominado granuloma tuberculoso. Essa primeira manifestação lesional característica constitui o chamado cancro de inoculação ou foco primário, estudado simultaneamente por Kiiss na França e Ghon na Alemanha, porém mais conhecido como nódulo de Ghon $^{34,191,236}$. Normalmente é único e com as dimensões citadas, mas há relatos da existência de múltiplos focos primários e de focos de maiores 
dimensões ${ }^{34,111,191,236,237}$. Na maioria dos indivíduos, o aparecimento do foco primário passa despercebido e se infere apenas pela sensibilidade tuberculínica. Em certos casos, porém, suas dimensões são suficientes para que possa ser demonstrado ao exame radiológico ${ }^{34}$.

Do cancro de inoculação os bacilos são drenados pelo sistema linfático, atingindo os gânglios regionais. $\mathrm{O}$ conjunto formado pelo foco primário, linfangite satélite e a adenopatia correspondente é conhecido como complexo primário de Ranke ${ }^{111,191,236}$. Cerca de 90-95\% da população infectada consegue bloquear o avanço do processo a partir da formação do complexo primário de Ranke, permanecendo apenas como infectados $93,111,133,191,299$.

O complexo primário pode curar-se pela calcificação, mas nem sempre, ela é total. Quando há caseificação, esta pode ser invadida parcialmente pela calcificação, deixando áreas com bacilos vivos. Esses bacilos vivos, quiescentes, são os que mantêm a imunidade adquirida e a sensibilidade à tuberculina. Se há cura com esterilização bacteriológica dos focos, o estado imunoalérgico se extingue e uma nova infecção pode criar um segundo complexo primário. A calcificação do complexo primário curado, pode ser surpreendida nas radiografias alguns meses depois da primo-infecção ${ }^{236}$.

No bovino, a tuberculose por M.bovis é geralmente de natureza crônica, lentamente progressiva e tendo como porta de entrada em 80 a $90 \%$ dos casos, as vias aéreas superiores 2, 68, 137, 180, 199, 201, 208, 214, 228, 237, 272, 281, 285 , podendo, no entanto, ocorrer também por via digestiva, particularmente nos animais jovens, quando se alimentam com leite de vacas com tuberculose na glândula mamaria 137, 199, 201, 237, 272.

Quando a infecção se dá pelo trato respiratório, o pulmão é o órgão mais atingido, assim como os linfonodos bronquiais e mediastínicos. Quando a infecção ocorre pela via digestiva, a lesão se dá no sítio de entrada, principalmente nos linfonodos faríngeos e mesentéricos 2, 68, 74, 143, 173, 199, 207, 208, 237, 240, 262.

A lesão pulmonar primária (foco primário) no gado é muito similar à lesão que ocorre no homem, ou seja, uma pequena lesão, geralmente única e extremamente 
pequena, se formará no local da infecção e um considerável aumento dos linfonodos drenará o segmento afetado do pulmão formando o complexo primário $^{2,68,74,143,173,199,207,208,237,262}$. Um trabalho publicado em 1986 por Mc Ilroy e col., demonstrou que $63 \%$ dos pulmões bovinos tuberculosos analisados, possuíam uma única lesão, e que $70 \%$ das lesões tinham um diâmetro inferior a $1 \mathrm{~cm}{ }^{199}$.

Enquanto no homem o complexo primário freqüentemente cura-se espontaneamente, no gado esse evento é raro. Por essa razão, um bovino tuberculinapositivo poderá ser uma fonte de infecção permanente para todo o rebanho $2,68,143,173,199,207,208,281$.

A evolução e a gravidade da infecção dependem basicamente da existência de fatores associados, ou seja: doenças intercorrentes, carência mineral, condições climáticas extremas, portanto, qualquer fator de "stress" que venha a quebrar a resistência do animal e permitir que as micobactérias usualmente restritas ao complexo primário ganhem a circulação e disseminem-se pelo organismo animal, atingindo os mais diversos órgãos 199, 201, 237, 272.

\subsection{2- SINAIS E SINTOMAS}

As diferenças na apresentação clínica da tuberculose humana devida ao M.bovis, estão relacionadas com as rotas de transmissão da infecção do animal para o homem, que podem ser diretamente pela via aerógena, mediante a inalação do bacilo, ou indiretamente pela ingestão de leite contaminado 42, 48, 57, 91, 93, 104, 127, 148, 160, 175, 196, 201, 217, 228, 237, 259, 295, 296 . Portanto, os sintomas da tuberculose pulmonar no homem são compatíveis com o de uma doença infecciosa, de curso geralmente crônico, no qual se destacam febre vespertina, emagrecimento, tosse, fadiga, dor no tórax, suores noturnos, astenia (fraqueza orgânica, debilidade) e, em sua forma clínica mais prevalente, tosse com expectoração que pode evoluir para escarros sangüíneos e hemoptise ${ }^{93,191,228,236}$.

Detalhados estudos epidêmicos na Dinamarca, realizados em 1945, levaram Sigurdsson à conclusão de que em epidemias por leite contaminado por M.bovis, o 
quadro clínico diferia da tuberculose pulmonar. Após 5 a 8 semanas da ingestão de leite tuberculoso, a doença iniciava-se com febre, dor de garganta, inflamação das amígdalas e linfonodos cervicais, vagos sintomas estomacais, ocasionalmente alargamento dos linfonodos mesentéricos, esporadicamente conjuntivites e muitas vezes eritema nodoso ${ }^{228}$.

Nos bovinos, o estágio inicial da doença não altera o estado geral e nutricional do animal e é caracterizado pela não elevação da temperatura corporal, por uma tosse entrecortada e violenta, e pela não alteração da respiração. À medida em que o processo patológico avança ocorrem hipetermias moderadas que duram dias ou semanas, a tosse torna-se dolorosa e freqüente, e a respiração vai ficando difícil e dispnéica ${ }^{237,281}$.

No final da enfermidade a febre é alta e contínua; a tosse é débil e úmida; nos casos de neoformações tuberculosas localizadas na laringe ouve-se um ruído ou estertor; os animais expulsam uma expectoração mucupurulenta pelos orifícios nasais nos acessos de tosse; as dificuldades respiratórias são cada vez maiores; as reses abaixam a cabeça, sacam a língua, emitem gemidos ou ruídos ao respirar e os membros torácicos, em especial os cotovelos, aparecem desviados para fora ${ }^{237,281}$.

Não poucas vezes os gânglios linfáticos pulmonares estão aumentados e podem impedir a erucção ao comprimir os nervos, produzindo um acúmulo de gases e meteorismo no ventre, com proeminência da parede abdominal na região do flanco esquerdo $^{237,281}$.

As infecções intestinais são mais freqüentes nos bezerros que em bovinos adultos, e a conseqüência é a diarréia persistente ${ }^{281}$.

Na tuberculose mamaria das vacas, não se observam manifestações clínicas no início, mas no período avançado da doença a mama perde sua simetria e apresenta nódulos consistentes e não dolorosos à apalpação. O leite muda seu aspecto, tornando-se floculento e aquoso e diminui progressivamente ${ }^{204,281}$. Quando a localização é uterina, percebe-se através de apalpação retal, nódulos e endurecimento da parede do útero e trompas, alterações que conduzem, fatalmente, à infertilidade ${ }^{204}$. 
As reses com lesões tuberculosas no encéfalo, meninges ou medula espinhal apresentam alterações do sistema nervoso central e convulsões, executando movimentos forçados. Em geral, caminham tropegamente e com a cabeça inclinada. A mastigação é lenta, a deglutição é prejudicada e pode haver perda da visão de um ou ambos os olhos. Próximas da morte sofrem paralisia geral e inconsciência ${ }^{237,281}$.

As manifestações clínicas descritas, não são observadas concomitantemente em um mesmo animal e nem sempre têm um caráter claramente definido ${ }^{281}$.

Nos casos de propagação das lesões a um ou vários órgãos, o que predomina no quadro clínico é um transtorno geral inespecífico. As reses se mostram preguiçosas e indiferentes, o pelo torna-se eriçado e sem brilho, o apetite é variável ou escasso, geralmente ocorre febre, aumento dos gânglios e rápido emagrecimento, as vacas reduzem progressivamente a produção de leite permanecendo deitadas e morrem em consequiência de um enfraquecimento crescente e da debilidade geral $^{204,281}$.

A maioria dos animais apresenta como sinais e sintomas, emagrecimento, tosse, fraqueza, chiado respiratório, conjuntivite e debilidade geral ${ }^{115,281}$. Entretanto, as evidências clínicas da doença não são aparentes nos casos crônicos, ocorrendo somente nos estágios terminais da enfermidade ${ }^{261}$.

Nos primatas não humanos, por exemplo, não existem sinais clínicos da tuberculose. Observa-se, em alguns casos, pelos ralos, secos e sem brilho; inatividade, e perda de peso. Certos animais não apresentam qualquer sintoma até a morte ${ }^{96}$.

Quando ocorrem sinais clínicos da tuberculose em cães e gatos, eles refletem o sítio primário da infecção ${ }^{60}, 131,157$. Broncopneumonia, formação de nódulo pulmonar e enfartamento de linfonodos, são mais comumente observados em cães, causando febre, perda de peso, tosse, dispnéia, apatia e anorexia ${ }^{60,131,157,187}$.

Os gatos, por desenvolverem uma primária localização intestinal com maior frequência que os cães, apresentam perda de peso, anemia, vômito e diarréia, como sinais de má absorção intestinal, podendo haver alterações na apalpação abdominal 
realizada pelo clínico ${ }^{131}$.

Entretanto, a doença disseminada pode ser o primeiro sinal clínico da doença em muitos cães e gatos, ocorrendo linfadenopatia generalizada, perda de peso, febre e morte súbita ${ }^{131}$.

\subsection{3- LESÕES}

A doença humana causada pelo M.bovis é indistinguível em relação à patogênese, lesões e achados clínicos da tuberculose causada pelo M.tuberculosis ${ }^{68}$, $110,125,129,196,216,228,283,298$. No homem, a tuberculose primária que ocorre durante uma primo-infecção, pode evoluir tanto a partir do foco pulmonar quanto do foco ganglionar ou então em conseqüência da disseminação linfohematogênica ${ }^{93,111,191,223}$. Em função do número de bacilos recebidos, da sua virulência, da hipersensibilidade e do estado imunológico do indivíduo, cerca de 5 a $10 \%$ evoluem para a doença primária nos 2 primeiros anos após a infecção e cerca de 90 a 95\% dos primo-infectados tornam-se antigos infectados, isto é, sem as alterações evolutivas próprias da doença $34,50,89,93,111,191,216$.

Em um novo contato com o bacilo da tuberculose (tuberculose pósprimária) alguns indivíduos controlam a infecção através do desenvolvimento da imunidade, quer pela infecção natural ou pela vacina BCG; mas 5 a $10 \%$ dos primoinfectados adoecerão mais tardiamente, em conseqüência do recrudescimento de algum foco quiescente já existente no seu organismo, contraído em uma primoinfecção na infância ou adolescência (reativação endógena), ou por receber nova carga bacilar do exterior, por meio de novo contágio (reinfecção exógena). Em geral, ambas ocorrem onde existe uma alta prevalência de casos infecciosos em uma comunidade, mas a reativação endógena torna-se a causa predominante da doença, nas regiões onde a tuberculose é rara ou está em declínio. Qualquer que seja a fonte de infecção, o processo de formação das lesões é o mesmo 111, 127, 142, 191, 223, 236.

Nas formas pós-primárias, inicialmente os bacilos irão localizar-se no terço superior do pulmão, e uma vez instalados no parênquima pulmonar, promoverão 
resposta tecidual específica, com formação de nódulos constituídos por linfócitos, histiócitos (macrófagos), células epitelióides e células gigantes (ambas macrófagos modificados), dispostas em arranjos denominados granulomas, havendo maior ou menor quantidade de necrose de caseificação (do latim: caseum, queijo) em função da hipersensibilidade. A formação do granuloma constitui o elemento fundamental da imunidade protetora, pois destrói o organismo invasor ${ }^{93,191,236 .}$

A lesão tuberculóide, denominada necrose de caseificação, pode organizar-se, isto é, cercar-se de uma cápsula fibrosa e calcificar-se internamente, constituindo um foco paucibacilar de infecção latente, ou a lesão caseosa pode sofrer um amolecimento ou liquefação do cáseo, que pode ser eliminado por via brônquica, formando então a lesão escavada denominada caverna tuberculosa, onde os bacilos

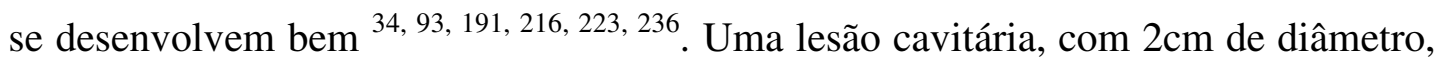
pode albergar de 100 milhões a 10 bilhões de bacilos. Este processo concorre para a disseminação broncogênica e formação de novos nódulos semelhantes, que poderão confluir e aglomerar-se, formando lesões maiores com várias formas e dimensões. Essa disseminação, além de atingir o pulmão, pode até mesmo comprometer a pleura. As cavidades podem conter necrose de caseificação, sangue ou ambos, e apresentam parede constituída por tecido pulmonar modificado e com infiltrado inflamatório crônico, associado às lesões granulomatosas ${ }^{93,191}$. A erosão dos vasos sangüíneos arteriais, resultando em um vazamento de sangue no interior das vias aéreas e a tosse repetida, com pus mesclado ao sangue arterial vivo (hemoptise), algumas vezes com consequiências fatais, são características da doença pulmonar pós-primária avançada, em humanos ${ }^{216}$. Podem ocorrer também, raramente, formas de disseminação hematogênicas primárias, como a tuberculose miliar (acometimento sistêmico) ${ }^{93,191}$.

Nas formas pós-primárias, esporadicamente se formam lesões diferentes, como, por exemplo, nódulos grandes e encapsulados, isolados ou múltiplos (tuberculomas), paucibacilares e sem comunicação com a árvore brônquica ${ }^{191}$.

Usualmente, o M.bovis é responsável por tuberculose pulmonar em pessoas expostas profissionalmente, e as formas disseminadas ocorrem com maior freqüência, em imunodeprimidos ${ }^{104}$. A rota digestiva da infecção normalmente 
resulta em formas extrapulmonares da doença, sendo as crianças mais afetadas se consumirem leite cru não fervido ou pasteurizado; e assim, as lesões ocorrerão nos linfonodos cervicais e, menos freqüentemente, nos linfonodos axilares. Esta condição, denominada escrófula, é comumente encontrada em regiões onde a tuberculose bovina é comum e o leite é consumido in natura ${ }^{196}$.

A primo-infecção tuberculosa por M.bovis em crianças, geralmente é seguida de rápida manifestação da doença. Os jovens são, portanto, um bom indicador da presença do bacilo bovino no meio ambiente. No adulto, a diminuição na incidência da tuberculose humana por M.bovis, tanto em suas formas pulmonares como extrapulmonares, ocorre mais lentamente, já que pode haver longos períodos de latência. Com o progresso dos programas de controle da tuberculose no bovino, os casos atuais concentram-se nos grupos de pessoas com idade mais avançada, principalmente por reativação endógena 4 , 89, 127, 148, 161, 196, 201, 228, 295, 296. Consequentemente, os idosos constituem hoje o reservatório do bacilo bovino, uma vez que podem alojar a infecção, sem a manifestação da doença, durante períodos de tempo muito prolongados ${ }^{154}$. Portanto, em crianças, a doença é primariamente o resultado de uma infecção alimentar e subsequente disseminação, enquanto em adultos, a doença pulmonar pós-primária é mais comum ${ }^{196}$.

A distribuição das lesões tuberculosas no bovino como mostra as informações provenientes de inspeções de carne, não deixam dúvidas de que a doença torácica é muito mais comum do que a doença nos órgãos abdominais. Sob muitas circunstâncias, cerca de 80-90\% das infecções tuberculosas por M.bovis no gado, ocorrem pela via respiratória 2, 68, 74, 78, 137, 173, 199, 201, 208, 216, 228, 237, 272 . Como no homem, o foco primário da infecção no pulmão pode estender-se localmente ou disseminar-se pelos sistemas linfático ou circulatório. A difusão local manifesta-se como uma aguda ou fatal broncopneumonia e formações cavitárias não são tão comuns no gado como no homem. A tuberculose disseminada também é relativamente incomum e estudos post mortem revelaram que a doença estava restrita ao tórax em 80-90\% dos animais 68, 173, 199, 208, 237, 262 . Entretanto, se ocorrer uma difusão hematogênica, surgirão lesões no baço, medula óssea, fígado, rins, glândulas supra-renais, útero, úbere, meninges ou cavidades serosas. Um complexo primário 
pode se desenvolver no intestino, após a ingestão de grande número de bacilos da tuberculose, principalmente nos bezerros, mas acredita-se que isso ocorra, mais freqüentemente, como resultado da disseminação de um complexo primário no pulmão $68,74,173,199,208,228,237,262$. Alguns autores sugerem que lesões nos linfonodos mesentéricos em animais adultos, originam-se de infecções secundárias ocasionadas pela deglutição do escarro, após observarem a excreção de M.bovis no muco nasal e fezes de bovinos infectados experimentalmente ${ }^{173,199,208 .}$.

Abatedouros da Grã-Bretanha demonstraram lesões confinadas no sistema pulmonar em $36,8 \%$ de vacas tuberculosas, e no trato intestinal, em 3,7\%. Na Austrália, 38\% do gado abatido apresentavam lesões na cavidade torácica e apenas $1,8 \%$ na cavidade abdominal, demonstrando que a tuberculose no gado, como no homem, é principalmente uma doença pulmonar. Igualmente no bezerro, a via respiratória da infecção é a mais importante. Um estudo dinamarquês encontrou lesões confinadas ao trato respiratório em $62,5 \%$ de 144 bezerros tuberculosos, $16 \%$ no trato intestinal e em $7 \%$ dos casos a doença, provavelmente, foi de origem congênita ${ }^{216}$.

No período de 1982 a 1990, dados provenientes de abatedouros da Irlanda do Norte, demonstraram que de 2.886 bovinos com lesões tuberculosas, 57\% tinham lesões confinadas ao trato respiratório (linfonodos bronquiais e/ou mediastínicos), $23 \%$ na cabeça (linfonodo retrofaringeal e submaxilar) e $4,7 \%$ tinham lesões em ambos os locais. Bovinos com lesões nos linfonodos mesentéricos foram, em média, $3,2 \%$, e a proporção de animais com lesões concomitantes no trato respiratório, cabeça e linfonodos mesentéricos, foi pequena. Lesões tuberculosas em outros tecidos e órgãos foram encontradas em aproximadamente $7 \%$ dos animais. Curiosamente, o número de sítios infectados foi em média 1,2 por animal, sugerindo que o controle da tuberculose no gado na Irlanda do Norte, com abate do gado tuberculina-positivo, foi eficiente em eliminar o gado tuberculoso nos estágios iniciais da doença ${ }^{208}$.

$\mathrm{Na}$ Grã-Bretanha demonstrou-se através de exames patológicos em bovinos com mais de 6 meses de idade, que o complexo primário localizava-se nos pulmões e 
linfonodos associados em pelo menos $60 \%$ dos casos, e na Austrália em 70 a $90 \%^{78,216}$.

Segundo Medlar, que estudou 520 pares de pulmões tuberculosos de bovinos abatidos em frigoríficos nos Estados Unidos e Canadá, entre todas as espécies animais infectadas pelo M.bovis, apenas a bovina desenvolve naturalmente uma tuberculose pulmonar progressiva crônica, que é comparável à doença no homem $^{216,237}$.

Evidências post mortem a respeito da freqüência da tuberculose das glândulas mamarias em vacas tuberculosas são um tanto conflitantes, mas testes biológicos de amostras de leite indicaram que o M.bovis é excretado no leite de aproximadamente 1 a $2 \%$ das vacas $68,125,216$. Este fato explica porque em 1932, na Inglaterra, apesar de $40 \%$ dos bovinos abatidos apresentarem macroscópicas lesões tuberculosas, apenas $0,5 \%$ das vacas leiteiras tinham o bacilo da tuberculose em seu leite ${ }^{68,259}$.

Apesar dos testes biológicos serem técnicas sensíveis, é possível que devido a erros na amostragem ou a excreções intermitentes do M.bovis no leite de vacas, haja uma subestimação do potencial risco do leite para a saúde pública ${ }^{216}$.

Em um estudo retrospectivo na Índia, baseado em achados de necropsia, foram encontradas lesões tuberculosas nas glândulas mamarias em $9(5,4 \%)$ de 168 (29 machos e 139 fêmeas) cabeças de gado tuberculosos com mais de 6 meses de idade. Tuberculose no úbere foi encontrada em 9 (6,5\%) das 139 vacas tuberculosas $^{216}$.

A tuberculose do sistema nervoso central é, usualmente, confinada a animais jovens e provavelmente o resultado de uma infecção congênita ${ }^{201,216}$. Mesmo que $5 \%$ das vacas apresentem tuberculose genital, apenas cerca de $1 \%$ dos bezerros serão infectados congenitamente ${ }^{199,201,216}$. Animais são classificados como congenitamente infectados quando as lesões são confinadas ao fígado, ou fígado e pulmões 2,137,208,216.

A tuberculose testicular é rara, e quando ocorre há alteração em somente um testículo, na forma de uma tumoração tuberosa e insensível. Também na vulva e vagina das vacas têm sido comprovadas lesões tuberculosas que excretam pus ${ }^{237,281}$. 
As reses tuberculosas que são sacrificadas apresentam lesões na forma de tubérculos ou de focos maiores cheios de pus, em quase todos os órgãos e partes corporais, de acordo com o grau de generalização ${ }^{281}$.

A tuberculose por M.bovis nos texugos é primariamente uma doença do tipo respiratória crônica. Como no gado, o desenvolvimento de uma broncopneumonia progressiva denuncia a doença pulmonar nos texugos. Nas lesões recentes são encontrados poucos bacilos, freqüentemente com células epitelióides ou área necrótica central. A lesão progride, aumentando o número de bacilos e a extensão da necrose. Não há encapsulação fibrótica e a calcificação é rara, resultando em uma disseminação hematogênica, com predileção pelos rins do animal 120, 149, 173, 210, 265 .

Em um estudo na Grã-Bretanha foi demonstrado que $22(71 \%)$ de 31 texugos selvagens naturalmente infectados apresentavam lesões grosseiras nos pulmões e/ou linfonodos torácicos, mas naqueles em que a difusão hematogênica havia ocorrido, o rim era o local preferido. Houve envolvimento renal em $6(19,4 \%)$ dos animais tuberculosos ${ }^{216}$.

Lesões cutâneas ocorrem devido a ferimentos por dentadas, provenientes de brigas entre os machos, resultando em abscessos e ulcerações na pele ${ }^{210,216}$. Em comparação ao bovino, apenas $2 / 3$ dos texugos infectados apresentam lesões visíveis no exame post mortem, sugerindo que o progresso da doença nesses animais é muito mais lento que no gado ${ }^{120}$.

No gambá, as lesões são semelhantes às do texugo, com exceção de lesões renais que são menos comuns nesses animais ${ }^{149}$.

A doença nos gambás é progressiva e invasiva, com grandes nódulos tuberculosos que possuem uma área central de necrose. Não existe uma cápsula fibrosa e a liquefação da área necrótica central produz um material purulento esverdeado que supura para o exterior, contendo um grande número de bacilos $^{70,173,199}$.

As lesões tuberculosas nos cervos são semelhantes às descritas para o gado, com raras calcificações ${ }^{194,}{ }^{265}$. Uma revisão da literatura indicou que exames post 
mortem de cervos tuberculosos revelaram lesões purulentas e caseosas em linfonodos retrofaringeais, torácicos e abdominais (linfonodos mesentéricos), além de lesões nos pulmões, fígado e baço ${ }^{61,108,134,173,199,216}$. Entretanto, grandes abscessos superficiais (medindo de $1 \mathrm{~mm}$ a $20 \mathrm{~cm}$ ) também ocorrem, podendo ou não supurarem para o exterior, em casos particulares ${ }^{61,199,265}$. Como as distribuições das lesões indicam, as principais rotas da infecção são o trato respiratório (inalação) e o digestivo (ingestão). A prevalência das lesões aumenta com a idade dos animais ${ }^{61,134,199,216}$. A baixa prevalência das lesões nos filhotes, e a ausência de lesões nas glândulas mamarias e útero das fêmeas prenhas infectadas, indicam que a transmissão transplacentária e através do leite não são fatores significantes na propagação da doença $^{61,216}$.

Os cervos podem abrigar uma enorme quantidade de bacilos e não apresentarem doença evidente. Invariavelmente quando os animais infectados demonstram sinais clínicos da doença, a morte ocorre em 1 a 2 semanas. As lesões tuberculosas, nesta fase, podem supurar de um tecido linfático, para formar abscessos ou cavidades com material purulento que escorre sobre a pele ou dentro do tórax do animal afetado ${ }^{61,134}$.

A tuberculose por M.bovis em macacos é geralmente progressiva, com lesões generalizadas, e os surtos epidêmicos ocorrem, principalmente, em colônias de $\operatorname{primatas}^{173}$.

Nos suínos, a principal porta de entrada é o sistema digestivo, com complexo primário na orofaringe e gânglios submaxilares, ou no intestino e gânglios mesentéricos; mas na tuberculose generalizada, lesões também podem ser encontradas nos pulmões, fígado e baço ${ }^{74,125,137,173,261,272}$.

Como nos bovinos, a tuberculose em búfalos é, quase exclusivamente, uma doença respiratória, com envolvimento dos órgãos torácicos ${ }^{186,199,216,228}$.

Como o sítio primário da infecção por M.bovis nos gatos é o trato digestivo, as lesões ocorrem mais frequentemente nos linfonodos mesentéricos e ileocecais, e no intestino 117, 131, 137, 178, 261 . Entretanto, geralmente formam um "complexo 
primário incompleto", ou seja, os bacilos ficam localizados no linfonodo, sem a formação de lesão no sítio de deposição ${ }^{131}$. Em outros casos, a disseminação hematogênica resulta em doença progressiva que atinge outros órgãos, incluindo os pulmões, com rara calcificação da lesão 117, 137, 178, 261.

Como os cães tendem a desenvolver infecções respiratórias com "complexo primário completo", as lesões são encontradas principalmente nos pulmões e linfonodos bronquiais sendo, geralmente, exudativas e não calcificadas $^{117,131,137,187,261}$.

A tuberculose miliar é mais comum em cães do que em gatos, e lesões na pleura, pericárdio, fígado, rins, coração, intestino e sistema nervoso central, são as mais frequentes. Os linfonodos mesentéricos, baço e pele são mais comumente envolvidos em gatos. Raramente são observadas lesões ósseas, articulares e genitais em cães, e lesões oculares em gatos ${ }^{60,131,157}$.

Nos eqüinos, apesar de rara, a tuberculose provoca lesões diferentes das que são observadas nos bovinos e suínos. As lesões primárias se encontram no trato digestivo, sob a forma de complexo primário incompleto, localizado nos gânglios retrofaríngeos e mesentéricos, sem lesão aparente na mucosa do aparelho digestivo ${ }^{74}$, 125, 136, 261 . Quando a mucosa intestinal apresenta alterações, estas apresentam o aspecto de úlceras intestinais, mais freqüentes no intestino grosso que no delgado. A lesão pode ficar confinada ao trato intestinal, mas nos casos graves pode generalizarse sob a forma de tuberculose miliar ou de grandes nódulos de aspecto tumoral, sendo os mais afetados os parênquimas pulmonar, hepático, esplênico, glandular, mamario e raras vezes, a pele ${ }^{74,136,137}$.

O aspecto da lesão é característico: não há caseificação abundante como no bovino e a calcificação é também pouco pronunciada, podendo ser despercebida. A lesão se apresenta como nódulos gordurosos de aspecto vítreo (semelhantes a gotas de orvalho) no pulmão, com um pequeno foco de caseificação central. Quando os nódulos aumentam de tamanho, por coalescência de nódulos pequenos, a lesão tuberculosa pode confundir-se com crescimento sarcomatoso ${ }^{74}$. 
Em infecções naturais ou experimentais com M.bovis, a tuberculose nas cabras é usualmente generalizada e envolve o pulmão mais severamente que outros órgãos. Pode também apresentar lesões no fígado e baço. Histologicamente, essas lesões são muito similares às observadas no bovino ${ }^{137,261}$. A tuberculose das glândulas mamarias não é incomum, e quando ocorre, o leite pode ser uma fonte de infecção para o homem ${ }^{137}$.

Em carneiros, as lesões também são semelhantes às observadas no gado, e a generalização da doença inclui a presença de lesões no pulmão, linfonodos bronquiais e mediastínicos, no baço e nos rins. As lesões são, freqüentemente, grandes e calcificadas 137,261 .

\section{4- DIAGNÓSTICO}

O raciocínio diagnóstico no homem desenvolve-se a partir do exame clínico, dos dados epidemiológicos e da interpretação dos resultados dos exames solicitados ${ }^{191}$.

O quadro sintomático é compatível com o de uma doença infecciosa de curso geralmente crônico, no qual se destacam febre, emagrecimento, astenia e, em sua forma clínica mais prevalente, tosse com expectoração que pode evoluir para escarros sangüíneos e hemoptise. O quadro clínico varia, evidentemente, com as diversas formas extrapulmonares que a tuberculose pode apresentar e a gravidade do caso ${ }^{191}$.

A investigação de história de contato com indivíduos ou animais tuberculosos, é de fundamental importância para a suspeição diagnóstica ${ }^{191}$.

Para o bovino, o diagnóstico clínico possui valor relativo, pois o animal pode estar infectado com foco localizado, e apresentar-se clinicamente sadio; situação na qual é difícil convencer o proprietário, visto que, a seu julgamento, animal tuberculoso é o animal caquético. A importância do exame clínico é evidente em animais que têm uma tuberculose evoluída e que se manifesta por meio de alguns sintomas clínicos como tosse seca, curta e repetitiva, e períodos febris. Ainda, como 
fator a ser analisado pelo clínico, na observação do rebanho em uma caminhada, constata-se que os animais tuberculosos geralmente vêm atrás dos demais, demonstrando cansaço e baixa capacidade respiratória. Outros sinais clínicos podem aparecer como, por exemplo, linfadenomegalia localizada ou generalizada ${ }^{201,237}$.

Ao contrário do que ocorre no animal vivo, as modificações observadas na necropsia, são facilmente reconhecidas como de natureza tuberculosa ${ }^{237}$. Os métodos diagnósticos mais utilizados são a tuberculinização e a detecção de lesões nos matadouros. Nos Estados Unidos e Canadá, enfatiza-se o isolamento do M.bovis a partir de tecidos suspeitos, e pesquisadores estão experimentando métodos complementares de diagnóstico ${ }^{218}$.

A não utilização de métodos adequados de isolamento e identificação do $M$. bovis em seres humanos e animais, não tem permitido que novos casos sejam diagnosticados, a exemplo do que ocorreu em outros países onde se julgava erradicada a tuberculose bovina ${ }^{4,125,130,145,264,283}$.

No mundo todo, a qualidade e quantidade de informações sobre a distribuição e prevalência da tuberculose bovina e tuberculose humana devida ao M.bovis nunca foram uniformes. Devido à aparente similaridade na apresentação clínica, tratamento e prognóstico da infecção no homem pelo M.bovis e M.tuberculosis, sempre houve falhas na tentativa de diferenciação entre estas bactérias pelos laboratórios, em muitos países do mundo 68, 89, 90, 125, 127, 129, 130, 145, 174, 196, 216, 228, 283, 297, 298.

O ideal seria que todo bacilo da tuberculose isolado da população humana, fosse adequadamente identificado e tipificado. A falha na distinção desses bacilos induz à falsa impressão de que medidas de controle para os bovinos foram suficientes para se considerar a doença humana por M.bovis quase extinta em muitos países desenvolvidos ${ }^{127}$.

Nos países em desenvolvimento, geralmente as informações disponíveis, são derivadas de uma pequena proporção da população, a qual não é representativa para um país como um todo ${ }^{196}$.

Outro fator complicante existente nas fontes de dados disponíveis é que até 
1970, o M.africanum era freqüentemente registrado como M.bovis por causa de suas semelhanças laboratoriais, e algumas vezes era referido como uma "variante bovina" do M.tuberculosis 127, 128, 148 . Entretanto, a epidemiologia e características das doenças causadas por essas duas micobactérias diferem marcadamente: o M.africanum não está associado com a doença no gado, e ocorre em jovens imigrantes, principalmente da África; já o M.bovis está associado a doença no bovino, e tende a ocorrer em uma faixa etária mais elevada, e em pessoas de origem étnica branca ${ }^{148}$.

Uma provável explicação para essa falha no diagnóstico da tuberculose causada pelo $M$.bovis, é que a confiança na eficácia da quimioterapia atual contra todos os tipos de tuberculose; a perda de interesse epidemiológico devido à queda na incidência da doença após a pasteurização do leite e abate do gado tuberculinapositivo; e as dificuldades encontradas nos procedimentos de identificação tenham resultado na perda de interesse em se diferenciar cepas humanas de bovinas. Contudo, desde que a tuberculose causada pelo M.bovis reapareceu em países nos quais ela estava praticamente erradicada; desde que a pirazinamida passou a ser regularmente usada como uma droga antituberculosa de $1^{\text {a }}$ linha e cepas bovinas são resistentes a ela, existe boas razão para que essa diferenciação seja feita $^{68,92,125,127,142,297}$.

\subsection{1- EXAMES DIAGNÓSTICOS}

Atualmente, os exames complementares mais utilizados na investigação diagnóstica da tuberculose no homem, após a realização do exame clínico, são: bacteriológicos, radiológicos, histopatológicos e imunológicos ${ }^{191}$.

No bovino, a tuberculose é diagnosticada in vivo pelos sinais clínicos e pelo teste tuberculínico (imunológico) e após a morte, pelos exames post mortem (na busca de lesões macroscópicas), bacteriológicos e histopatológicos. O exame radiológico só é utilizado em ocasiões especiais ${ }^{240}$.

Outros métodos de exame, mais complexos, vêm sendo testados e serão 
comentados mais adiante ${ }^{191}$.

\subsubsection{1- Bacteriológicos}

A pesquisa bacteriológica é o método mais importante, tanto para o diagnóstico, como para o controle de tratamento ${ }^{193,236}$.

Uma vez que nem os achados clínicos, nem a localização da doença, aspéctos das lesões ou exames histopatológicos são capazes de permitir a identificação do tipo de bacilo (M.tuberculosis ou M.bovis) que está causando a tuberculose, apenas pesquisas bacteriológicas adequadas atingem esse objetivo ${ }^{110}$.

Os procedimentos microbiológicos básicos para o diagnóstico etiológico das doenças causadas por micobactérias incluem: pesquisa de bacilos álcool-ácidos resistentes (BAAR) por microscopia direta (baciloscopia), e cultura dos espécimes clínicos, seguida da identificação das espécies isoladas, embora exista atualmente a disponibilidade de técnicas diagnósticas mais avançadas 53, 87, 89, 115, 142, 193, 237, 261, 296.

A baciloscopia é o procedimento diagnóstico prioritário, porque permite descobrir as fontes mais importantes da infecção que são os casos bacilíferos, além de ser um método simples, seguro, rápido e de baixo custo $53,93,191,192,193,233$. Os dois tipos de corantes mais freqüentemente utilizados são a fucsina fenicada e os corantes fluorescentes, como a auramina e rodamina. O esfregaço corado pela fucsina fenicada (método de Ziehl-Neelsen) é examinado em microscópio ótico com objetiva de imersão, enquanto que aquele corado pela auramina e/ou rodamina exige microscópio de fluorescência 53, 93, 142, 192, 236. A microscopia fluorescente é mais rápida e mais sensível do que a microscopia ótica comum. A utilização de uma objetiva de menor capacidade de resolução reduz o tempo necessário para examinar a superfície de um esfregaço, uma vez que o campo visualizado é 25 vezes maior do que aquele observado através da objetiva de imersão. $O$ aumento da sensibilidade é atribuído à maior probabilidade de detecção dos BAAR face à maior área do esfregaço examinada e à maior facilidade de visualização dos bacilos fluorescentes ${ }^{53}$, 142, 192 . O método da coloração fluorescente pode proporcionar até $30 \%$ mais de 
achados positivos que o de Ziehl-Neelsen ${ }^{8}$.

Na prática, a baciloscopia é, por si só, de grande valor diagnóstico, aconselhando-se como rotina, nos doentes em tratamento, a repetição mensal de exames baciloscópicos quantitativos. Nos casos com evolução favorável, observa-se uma redução progressiva do número de bacilos até o seu desaparecimento completo, ao redor de 3 meses. A persistência da baciloscopia positiva servirá como sinal de advertência à mudança de um esquema terapêutico ineficaz ${ }^{3,34,93,236}$.

A cultura apresenta uma sensibilidade maior que a baciloscopia. Para uma baciloscopia de escarro ser positiva, são necessários 5.000 a 10.000 bacilos por mililitro deste espécime, enquanto a cultura é capaz de detectar apenas 10 bacilos por mililitro de material concentrado e digerido. Desta forma, a cultura assume uma grande importância para a detecção de BAAR em espécimes extrapulmonares, e dos suspeitos de tuberculose pulmonar persistentemente negativos ao exame direto $^{34,53,93,111,142,191,192,193}$. Além de que, o cultivo permite posterior identificação da micobactéria isolada, assim como a realização do teste de sensibilidade a antibióticos $^{53,192}$.

Nos laboratórios que realizam a cultura, cerca de $70 \%$ dos casos de tuberculose pulmonar confirmados bacteriológicamente são diagnosticados pela baciloscopia e $30 \%$ pela cultura ${ }^{192}$. Entretanto, a literatura mundial registrou variações de 55\% a 66\% na confirmação bacteriológica pela baciloscopia, sendo que, no Brasil a média tem sido de $65 \%$, em relação ao total de casos pulmonares. A confirmação bacteriológica pela cultura também variou, mundialmente, de 4 a $30 \%$. Acredita-se que essas variações sejam influenciadas por peculiaridades de cada região em relação à gravidade da doença e pela diminuição da sensibilidade do método decorrente da associação da tuberculose com a AIDS. Nos locais onde o rendimento é elevado, possivelmente seja devido à seleção da população examinada, por utilização inicial do exame radiológico, principalmente nos grandes centros urbanos, onde é maior a disponibilidade deste recurso diagnóstico ${ }^{113}$.

A cultura dos espécimes clínicos pode ser rotineiramente realizada através da sua inoculação em meios de cultura sólidos que contenham, além de ingredientes 
adequados ao crescimento ótimo das micobactérias (ovo, fécula de batata, asparagina, glicerina), um corante capaz de inibir a flora de contaminação (usualmente, verde de malaquita). Os mais recomendáveis são os meios de Löwenstein-Jensen e o meio ATS (American Trudeau Society), que contém respectivamente $0,75 \%$ e $1 \%$ de glicerina, e por isso permitem o crescimento tanto do bacilo humano como o do bovino, ou naqueles à base de ágar, como o Middlebrook 7H10 e 7H11 e meio de ágar sangue, também chamado B83 34, 78, 93, 142, 192, 264. Existem também meios de cultura líquidos para o cultivo do bacilo da tuberculose, tais como: caldo glicerinado a 5\%, 7H9 de Middlebrook, meio de Sauton, Long e Seibert, Dubos e outros 2, 4, 52, 68, 74, 77, 78, 154, 192, 236, 264.

O M.bovis tem dificuldade em crescer em meios de cultura glicerinados, por esse motivo cresce melhor no meio de Stonebrink, que contém piruvato de sódio e não glicerol $2,4,52,68,74,77,78,154,192,236,264$. Apesar dos meios a base de ágar serem mais facilmente contaminados, recomenda-se a sua utilização juntamente com os meios à base de ovo e uma pequena concentração de $\mathrm{CO}_{2}$ (não superior a $5 \%$ ), para o isolamento primário do M.bovis ${ }^{77,78}$. Os principais fatores que influenciam o sucesso do isolamento primário do M.bovis nos espécimes clínicos são: o meio de cultura utilizado, o processo de descontaminação e as condições de incubação ${ }^{78}$.

A temperatura ideal de crescimento é de $37^{\circ} \mathrm{C}$. Do ponto de vista diagnóstico, as principais desvantagens da cultura são o tempo demasiadamente prolongado (21 a 30 dias) entre a inoculação e o surgimento de colônias macroscopicamente visíveis e o fato de requerer organismos viáveis para sua realização, exigindo uma adequada manipulação dos espécimes clínicos ${ }^{142,264,277 .}$

Apesar do M.bovis crescer melhor em meios de cultura que contenham piruvato de sódio, algumas cepas não demonstram preferência pelo substrato, crescendo também nos meios contendo glicerol. Por esse motivo, o crescimento diferencial nesses dois meios de cultura sugere, mas não confirma que a cepa isolada é de M.bovis ${ }^{126,128}$.

Os espécimes clínicos utilizados para o isolamento de micobactérias no homem podem ser contaminados, ou seja, aqueles que apresentam flora microbiana 
associada, como é o caso de escarro, urina, lavados, aspirados, secreção de cavidade aberta, biópsias e materiais ressecados de órgãos que se comunicam com o exterior; ou não contaminados como líquor, derrames serosos, sangue e tecidos. As amostras não contaminadas devem ser semeadas diretamente, sem qualquer tratamento prévio descontaminante, ao passo que as amostras contaminadas, antes de semeadas, devem sofrer um tratamento com substâncias químicas, com as seguintes finalidades: eliminação da flora associada, que por se desenvolver muito mais rápido, contamina o meio de cultura e impede a multiplicação dos bacilos; liquefação do muco e da fibrina e conservação da viabilidade do bacilo da tuberculose. O método de descontaminação mais difundido é o de Petroff que utiliza o hidróxido de sódio a 4\% como agente fluidificante e descontaminante $53,68,74,80,93,191,192,193,236,264$. Existem outros métodos, tais como o lauril sulfato de sódio, ácido oxálico a 5\%, método de Corper e Stoner modificado (fosfato trissódico a 23\% + fosfato monossódico a 20\%), método de Kubica e Dye ( $\mathrm{N}$-acetil-L-cisteína-hidróxido de sódio = NALC-NaOH), método de Jensen (ácido sulfúrico a 4\%) e o método do cloreto de cetilpiridínio (CCP), que é somente indicado para conservação e transporte de escarro $^{52,53,74,93,192,264}$.

No bovino, as amostras para a investigação do bacilo da tuberculose podem ser o muco laríngeo e traqueal colhido com um swab (porque o bovino não expectora), fezes, urina, leite, fluxo uterino ou pus, e os materiais colhidos por punção: exsudatos, líquidos articulares e cefalorraquidianos 8, 237. As peças anatômicas (biópsias) procedentes de gânglios linfáticos submaxilares, retrofaríngeos ou outros, são fundamentais para o encontro do bacilo ${ }^{53,74}$. A coleta dos gânglios deve ser totalmente asséptica, para prevenir ou minimizar a contaminação dos tecidos com terra e fezes que podem conter outras micobactérias ou outros microrganismos que poderiam interferir na cultura, obscurecendo o M.bovis ${ }^{78}$. O sangue é colhido apenas em casos excepcionais porque se apresenta bacilífero por um tempo limitado ${ }^{8,237}$.

Uma tentativa diagnostica da tuberculose nos bovinos, é a detecção macroscópica de lesões típicas na necropsia. O exame histopatológico da lesão pode aumentar a confiança do diagnóstico, mas apenas o isolamento bacteriológico do 
M.bovis fornece um diagnóstico definitivo. Entretanto, o longo tempo requerido para o isolamento e identificação do M.bovis faz com que, nos locais onde a prevalência da doença é alta, a cultura não seja solicitada, baseando-se o diagnóstico apenas no encontro de lesões macroscópicas, durante o exame post mortem. A cultura é necessária nos locais onde a prevalência da doença é baixa, como nos estágios finais de uma campanha de erradicação, ou quando o animal não apresenta lesões macroscópicas visíveis, mas é reator à tuberculina ${ }^{78}$.

O diagnóstico clínico e laboratorial da infecção por M.bovis em texugos por amostras de fezes, urina, e aspirados traqueais, semeados em meios de cultura apropriados, são pouco recomendados, devido à ausência de sinais clínicos no início da doença, e ao tempo requerido para identificar as culturas positivas ${ }^{210}$. Investigações da epidemiologia e ecologia da doença nos texugos requerem o desenvolvimento de um diagnóstico de confiança, preferivelmente um teste imunológico para uso em animais vivos, presos em armadilhas ${ }^{123,124,180,216,286}$.

Outros dois novos métodos de cultura são o sistema bifásico, que consiste em um meio solidificado (7H10, 7H11, Löwenstein-Jensen) e um meio líquido (7H9), para o isolamento de micobactérias do sangue e de materiais paucibacilares; e o sistema de lise-centrifugação que permite a lise das células sangüíneas para proporcionar a liberação das micobactérias que estejam em seu interior, e a concentração por centrifugação, sendo que o sedimento pode ser semeado em meios de cultura convencionais ou no sistema BACTEC, que veremos adiante ${ }^{192}$.

A inoculação em animais é um método sensível, mas de operacionalização complexa, apresentando dificuldades que lhe são inerentes como o estoque de animais hígidos, instalações adequadas de biotério, proteção do pessoal, morte dos animais por infecções intercorrentes, e outras. É um método oneroso, de resultado demorado e não detecta bacilos de baixa virulência como, por exemplo, os mutantes isoniazida resistentes, o que o afasta da rotina do laboratório de bacteriologia da tuberculose ${ }^{34,236,297}$. Quando realizado, o cobaio, o coelho e o camundongo são os animais de laboratório mais utilizados no estudo experimental da tuberculose ${ }^{34}$. 
O cobaio é extremamente susceptível à micobactéria da tuberculose humana ou bovina, e pode ser infectado com um só microrganismo isolado no micromanipulador. Quando inoculado pela via subcutânea (face interna da coxa), o animal diminui progressivamente de peso e morre ao fim de 2-3 meses, apresentando na necropsia linfadenite generalizada e acentuado aumento de volume do fígado e do baço, cujas superfícies se revestem de um pontilhado amarelo ${ }^{34,236}$. O pulmão é atingido com menor freqüência e mais tardiamente. Se a inoculação for feita pela via peritonial, a evolução do processo é mais rápida, vindo o animal a morrer dentro de 2-6 semanas. O cobaio pode também ser infectado por inalação ou por injeção direta na traquéia, desenvolvendo neste caso, lesões pulmonares e acentuada adenopatia tráqueo-brônquica ${ }^{34}$.

Injetado subcutâneamente com 0,1-1,0mg de bacilos bovinos, o coelho desenvolve doença mortal em 2-3 meses. Na necropsia, apresenta lesões nodulares particularmente nos pulmões e rins. Doses de 1-100mg de bacilos humanos, pela mesma via (subcutânea), determinam infecção crônica, sem tendência à generalização ${ }^{34}$.

Quando a infecção é feita por via venosa, os coelhos inoculados com 0,010,1mg de bacilos bovinos, morrem em 3-6 semanas, ao passo que a inoculação de doses correspondentes de bacilos humanos, raramente determina infecção mortal ${ }^{34}$.

A patogenicidade para o coelho constitui um método precioso para diferenciar os tipos humano e bovino do bacilo da tuberculose, devido à sua elevada resistência ao M.tuberculosis e susceptibilidade ao M.bovis. O M.tuberculosis é mais patogênico para o cobaio do que para o coelho, enquanto o M.bovis tem uma maior patogenicidade para ambos 34, 110, 236, 297. Tanto no coelho, como no cobaio, a inoculação do bacilo aviário é incapaz de conduzir à formação de tubérculos macroscopicamente visíveis, embora o bacilo possa ser demonstrado em esfregaços e culturas dos órgãos internos ${ }^{34}$.

O camundongo também pode ser utilizado no estudo das micobactérias, pois desenvolve lesões progressivas após a inoculação intraperitonial ou venosa de qualquer dos tipos de bacilo da tuberculose, bem como das MOTT ${ }^{34}$. 
Este procedimento fundamenta-se nos "Postulados de Koch" que para comprovar que um determinado germe seja a causa de uma doença infecciosa, baseia-se nas seguintes normas por ele instituídas:

1- "Deverá encontrar-se sempre o microrganismo em todos os casos da enfermidade em questão".

2- "Deverá isolar-se em cultivo puro a partir do organismo enfermo".

3- "Os cultivos deste germe deverão reproduzir a enfermidade nos animais susceptíveis".

4- "O germe deverá ser isolado novamente das lesões do animal inoculado" ${ }^{8}$.

Pelos motivos expostos acima, e por razões de economia e rapidez, atualmente substitui-se o método de inoculação em animais, por procedimentos de classificação bacilar in vitro ${ }^{8}$. Acredita-se hoje, que a cultura seja tão sensível como a inoculação animal, para o isolamento primário do M.bovis ${ }^{2,78}$.

Anerik (1974) $)^{8}$, estudou comparativamente os métodos de cultivo e inoculação em animais de laboratório, na Venezuela, em um total de 302 amostras; sendo 66 de leite, 119 de gânglios linfáticos e 117 de órgãos internos de bovinos positivos à prova tuberculínica ou suspeitos de estarem tuberculosos, obtendo 120 resultados positivos $(39,7 \%)$ no meio de Stonebrink-Lesslie e $125(41,4 \%)$ na inoculação animal. Demonstrou que o meio de Stonebrink-Lesslie foi o mais eficaz para o isolamento primário do M.bovis, já que no meio de Löwenstein-Jensen sem glicerina apenas 113 amostras foram positivas e no Löwenstein-Jensen com glicerina a $0,75 \%$, somente 91 amostras $^{8}$.

Com esse estudo, Anerik concluiu que o método de cultivo é equivalente em eficácia ao de inoculação em animais, obtendo $96 \%$ de positividade, e com a vantagem de ser menos dispendioso, mais rápido e mais humanitário, suprimindo o desnecessário sofrimento dos animais de experimentação ${ }^{8}$.

As cepas humana e bovina eram originariamente tipificadas de acordo com sua virulência para o coelho e pelas características de crescimento em meios de 
cultura. Posteriormente, foram desenvolvidos testes bioquímicos para a diferenciação das duas cepas ${ }^{128}$.

Segundo Pritchard, $(1988)^{228}$ em uma revisão de um século de tuberculose bovina (1888-1988), e diversos outros autores, os testes mais amplamente usados para a identificação do Mycobacterium bovis são os descritos a seguir:

$\Rightarrow$ morfologia bacilar e velocidade de crescimento;

$\Rightarrow$ intensificação de glicerol para o crescimento do Mycobacterium tuberculosis e supressão para o Mycobacterium bovis;

$\Rightarrow$ síntese da niacina pelo M.tuberculosis e não pelo M.bovis;

$\Rightarrow$ morfologia colonial - M.tuberculosis produz colônias exuberantes (eugônicas), e o M.bovis pequenas colônias planas (disgônicas);

$\Rightarrow$ intensificação de piruvato para o crescimento do M.bovis;

$\Rightarrow$ preferência ao oxigênio - M.bovis é microaerófilo e M.tuberculosis é aeróbico;

$\Rightarrow$ ambos não crescem a $25^{\circ} \mathrm{C}$ e $42^{0} \mathrm{C}$, isto é são estritamente mesófilos e não pigmentados;

$\Rightarrow$ o nitrato é reduzido pelo M.tuberculosis mas não pelo M.bovis;

$\Rightarrow$ resistência à pirazinamida do M.bovis e sensibilidade do M.tuberculosis;

$\Rightarrow$ susceptibilidade ao TCH (hidrazida do ácido tiofeno-2-carboxílico) pelo M.bovis, mas não pelo M.tuberculosis;

$\Rightarrow$ sensibilidade do M.bovis ao ácido p-aminosalicílico 53, 68, 74, 89, 128, 196, 228, 236, 298.

Barrow e Gallagher $(1981)^{26}$ utilizaram um método de tipificação do M.bovis em 1980, descrito por Grange em 1976, para a detecção de variações intra-específicas do bacilo, baseado na habilidade das cepas utilizarem ou removerem aminoácidos de 
soluções aquosas. Este método foi usado na investigação de um surto de tuberculose bovina no gado em Gloucestershire, na Inglaterra, onde texugos foram implicados como a fonte de infecção. Os resultados obtidos sugeriram que esse método poderia ser utilizado no estudo da epidemiologia da tuberculose bovina em animais selvagens, gado e homens ${ }^{26}$.

Collins e col. em 1981 e 1982 definiram a cepa bovina "clássica" (M.bovis) como sendo sensível ao $\mathrm{TCH}$, microaerófila, nitrato negativa e resistente à pirazinamida ${ }^{68,125}$.

Algumas cepas variantes do M.bovis foram descritas mais recentemente, envolvendo certas regiões geográficas ou, em particular, reservatórios animais. Essas cepas eram sensíveis à pirazinamida e ao $\mathrm{TCH}$, e algumas eram nitrato positivas. Foram isoladas na Grã-Bretanha, e eram provenientes de imigrantes asiáticos e africanos, por isso, foram denominadas cepas bovinas afro-asiáticas ou variedade afro-asiática do M.bovis ${ }^{68,125}$.

Em 1981, Hein e Tomasovic isolaram 25 cepas de M.bovis em búfalos da espécie Bubalus bubalis na Austrália, e essas cepas cresceram bem em meio de Löwenstein-Jensen contendo glicerol ou cloreto de sódio a $5 \%$, sugerindo que em poucos anos os métodos de tipificação usados atualmente, parecerão extremamente primitivos 68,297 .

Em 1983, Kotian e col. registraram o isolamento de 6 cepas de M.tuberculosis, as quais foram incapazes de tipificarem, por isso, classificou-as como intermediárias entre as variantes humana e bovina. É possível que no futuro, mais variedades do bacilo da tuberculose sejam reconhecidas, com a introdução de novas técnicas diagnosticas ${ }^{297}$.

Segundo Grange e Yates, (1994) ${ }^{128}$, foram selecionados 4 testes, que são atualmente usados extensivamente nos estudos epidemiológicos das tuberculoses humana e animal. Estes testes são a atividade do nitrato (redução), preferência ao oxigênio, susceptibilidade ao TCH e susceptibilidade à pirazinamida ${ }^{128}$. O teste da niacina não é tão discriminatório como os mencionados acima, porque em certas 
ocasiões ele é negativo para o M.tuberculosis (quando deveria ser positivo) e produz resultados variáveis para cepas de M.africanum, mas ainda é bastante utilizado pelos laboratórios, devido à sua rapidez e simplicidade ${ }^{128,297}$.

Estes testes dividem o complexo M.tuberculosis em 6 variantes como mostra a tabela 1:

Tabela 1 - Tipificação Do Complexo M.tuberculosis

\begin{tabular}{llccccc}
\hline \multicolumn{1}{c}{ ESPÉCIES } & VARIANTES & TCH & NO $_{3}$ & $\mathbf{O}_{2}$ & PZA & NIACINA \\
\hline M.tuberculosis & Humana clássica & $\mathrm{R}$ & + & $\mathrm{A}$ & $\mathrm{S}$ & + \\
& Humana asiática & $\mathrm{S}$ & + & $\mathrm{A}$ & $\mathrm{S}$ & + \\
M.africanum & Tipo I & $\mathrm{S}$ & - & $\mathrm{M}$ & $\mathrm{S}$ & $+/-$ \\
& TipoII & $\mathrm{S}$ & + & $\mathrm{M}$ & $\mathrm{S}$ & $+/-$ \\
M.bovis & Bovina clássica & $\mathrm{S}$ & - & $\mathrm{M}$ & $\mathrm{R}$ & - \\
& BCG* & $\mathrm{S}$ & - & $\mathrm{A}$ & $\mathrm{R}$ & - \\
\hline
\end{tabular}

TCH = Susceptibilidade à hidrazida do ácido tiofeno-2-carboxílico;

$\mathrm{NO}_{3}=$ Nitratase atividade ou redução do nitrato;

$\mathrm{O}_{2}=$ Preferência ao oxigênio;

PZA = Susceptibilidade à pirazinamida ou pirazinamidase atividade;

R = Resistente; S = Sensível; (+) = Positivo; (-) = Negativo; (+/-) = Reação variável; $\mathrm{A}=$ Aeróbico; $\mathrm{M}=$ Microaerófilo.

* Um teste confirmatório para BCG é a resistência à cicloserina ( $20 \mathrm{mg} / \mathrm{l}$ em meio de Löwenstein-Jensen).

FONTE: WHO/Zoon./94 - Guidelines for speciation within the Mycobacterium 
tuberculosis complex. 
Uma vantagem deste esquema de tipagem é que as variantes mais freqüentemente isoladas de humanos e animais (M.tuberculosis clássica e M.bovis clássica) diferem em todos os testes. Cepas de M.africanum são divisíveis em 2 tipos. O tipo I é feneticamente semelhante ao M.bovis e é encontrado principalmente no oeste da África, enquanto o tipo II tem características em comum com o M.tuberculosis e ocorre principalmente no leste da África. A omissão do teste para a susceptibilidade à pirazinamida poderia levar a uma falha na discriminação de cepas de M.bovis e M.africanum tipo I e tipo II ${ }^{127,128}$.

Os testes considerados mais discriminativos e mais úteis para a identificação do M.bovis são a resistência à pirazinamida e a sensibilidade ao $\mathrm{TCH}^{126}$.

Este esquema de tipagem também pode ser aplicado na diferenciação de cepas de M.bovis de bovinos e mamíferos selvagens ${ }^{127}$.

O teste de sensibilidade aos tuberculostáticos é realizado apenas nos casos de tuberculose humana, uma vez que a quimioterapia é impraticável em animais, salvo em raríssimas exceções, como veremos posteriormente na seção dedicada ao tratamento da tuberculose.

O teste pode ser realizado pelo método das concentrações absolutas, método da relação de resistência e o método das proporções, para caracterizar o estado de susceptibilidade da população bacteriana que infecta o paciente, frente aos antibióticos utilizados no tratamento da tuberculose. O método das proporções, descrito em 1963 por Canetti, Rist e Grosset, é o mais aplicado, e avalia a proporção de bacilos resistentes existentes em uma determinada população, incluindo-se no teste concentrações adequadas de bacteriostáticos (concentração crítica concentração de droga capaz de inibir o desenvolvimento das células sensíveis, mas não das células resistentes), tubos-controle não adicionados de drogas, e as proporções críticas de resistência (para cada droga foi definida uma proporção de mutantes resistentes em uma população bacilar, igual ou acima da qual a amostra é considerada resistente) à cada antibiótico $34,53,192,236$. 
Os testes de sensibilidade aos quimioterápicos têm indicação nos casos crônicos de tuberculose, submetidos a diferentes esquemas de tratamento, refletindo as falhas ou ineficiência dos esquemas praticados e para avaliar as tendências epidemiológicas da resistência bacteriana, servindo como guia de eleição de esquemas terapêuticos ${ }^{113}, 236$. A utilização desses métodos para avaliar a sensibilidade de outras micobactérias que não sejam do complexo M.tuberculosis não é recomendada, pois os resultados obtidos, geralmente, não apresentam uma boa correlação com a resposta terapêutica do paciente ${ }^{192}$.

Considera-se que a sensibilidade do M.bovis às drogas seja semelhante à do M.tuberculosis, porém existem vários problemas técnicos para que ela possa ser investigada in vitro. Um dos problemas é o crescimento disgônico do bacilo bovino nos meios comumente usados para a cultura do bacilo humano, e outro, é que a utilização de meios apropriados para o cultivo do bacilo bovino, contendo piruvato de sódio, demonstrou que esta substância inibe a atividade de certas drogas antituberculosas (principalmente a isoniazida e a ciclocerina), tornando impossível a determinação da sensibilidade do bacilo às mesmas. Portanto, não se deve efetuar provas de sensibilidade no meio de Stonebrink ${ }^{4,53,74,153,154 .}$

O emprego de um meio de cultura que contenha glutamato de sódio no lugar do piruvato de sódio, não afeta a ação das drogas e permite a realização do teste de sensibilidade aos tuberculostáticos em cepas de M.bovis ${ }^{53,74,153}$.

\subsubsection{2- Radiológicos}

O exame radiológico é outro método complementar bastante utilizado. Apesar de sua baixa especificidade, na investigação diagnostica de formas pulmonares no homem, ele está indicado nos seguintes casos: sintomáticos respiratórios negativos à baciloscopia direta; comunicantes de todas as idades, sem sintomatologia respiratória; suspeitos de tuberculose extrapulmonar, nas quais o acesso à lesão para coletar material para exame costuma ser mais difícil; e portadores do HIV ou pacientes com AIDS, como diagnóstico diferencial de formas ditas 
atípicas ou MOTT, ou ainda, de outras pneumopatias. Não se justifica como rotina, o emprego do exame radiológico fora dos grupos acima mencionados. É importante lembrar que não existe imagem patognomônica de tuberculose na radiografia do tórax e sim, imagem sugestiva ${ }^{191,193}$.

Até recentemente a radiologia teve papel preponderante na luta contra a tuberculose. Rastreamento de casos através de abreugrafia em massa, diagnóstico, controle do tratamento e verificação da cura dos doentes, tudo dependia, em grande parte, dos meios radiológicos. A aquisição de novos conhecimentos científicos e de novos recursos técnicos, particularmente a prova tuberculínica e as drogas antimicrobianas, propiciaram a redução do emprego da radiologia ${ }^{3}$.

Em animais, o exame radiológico é utilizado somente quando o animal é de alto valor zootécnico. Portanto, neste caso, o raios-X pode ser usado também no bovino, como uma técnica alternativa auxiliar no diagnóstico da tuberculose. As maiores dificuldades para a realização desse exame nos bovinos consistem no tamanho da caixa torácica e dos órgãos nela contidos, além da indocilidade da maioria dos animais ${ }^{267}$.

No Brasil, Canola e Marques (1989) ${ }^{51}$, descreveram o uso do raios-X em 3 vacas leiteiras, provenientes de uma propriedade em Monte Alto, São Paulo, e que apresentavam queda acentuada da produção láctea, tosse, corrimento nasal seroso bilateral, pelos arrepiados e emagrecimento progressivo, chegando ao grau de caquexia, embora estivessem recebendo ração balanceada. Em virtude das dificuldades em encontrar tuberculina disponível no comércio, para o diagnóstico da tuberculose, realizaram radiografias laterais do tórax dos 3 animais, que forneceram imagens sugestivas da doença. Os animais foram sacrificados e necropsiados, e os achados anátomo-patológicos confirmaram a suspeita ${ }^{51}$.

\subsubsection{3- Histopatológico}

O exame histopatológico é outro método diagnóstico que pode ser empregado, principalmente, na investigação das formas extrapulmonares da 
tuberculose em humanos, e em material de biópsia, proveniente de lesões encontradas no exame post mortem dos animais, especialmente bovinos ${ }^{173,191}$. As lesões produzidas pelo M.tuberculosis e M.bovis são semelhantes ao exame histopatológico, apresentando-se como um granuloma, geralmente com necrose de caseificação e infiltrado histiocitário ${ }^{191,199}$. Deve-se ressaltar que esta apresentação também ocorre em outras doenças, portanto, apenas o achado do BAAR na lesão permite afirmar a etiologia tuberculosa, sendo ainda necessário o isolamento e posterior identificação da micobactéria ${ }^{173,191}$.

\subsubsection{4- Imunológicos}

A prova tuberculínica, que indica contato prévio com o bacilo de Koch, é outro exame complementar que pode ser utilizado no homem, e de fundamental importância no diagnóstico da tuberculose em bovinos ${ }^{191,193,240 .}$

Robert Koch, em 1890, preparou de culturas de bacilo da tuberculose, um produto que verificou ser extremamente tóxico para animais tuberculosos, porém relativamente inócuo para animais sãos. $O$ produto foi denominado tuberculina $^{34,137,197,228,236}$.

Koch preparava a sua antiga tuberculina (em alemão, Alt Tuberckulin, A.T.; em inglês, Old Tuberculin, O.T.) de culturas, em caldo de carne glicerinado, mortas por autoclavação ou evaporadas em banho-maria ${ }^{34,197,201,228,236 .}$

Koch imaginou ter descoberto um remédio para a cura da tuberculose. Centenas de doentes acorreram para serem tratados com a tuberculina, cujas doses, então empregadas, desencadearam fenômenos intensos, reações lesionais agudas e destruições tissulares, levando muitos à morte. Esse desastre marginalizou a tuberculina até 1908, quando von Pirquet, criador do termo "alergia", demonstrou que, se a tuberculina fosse introduzida nos organismos em pequena dose, não desencadeava graves reações gerais e focais, mas apenas produzia pequena resposta inflamatória local na pele. Essa reação indicava que o organismo estava infectado com o bacilo da tuberculose. Estava assim descoberto o tuberculina-diagnóstico, que 
proporcionou extraordinário avanço nos conhecimentos da patogenia clínica e epidemiologia da tuberculose ${ }^{236,237}$.

Várias técnicas foram propostas para a purificação da tuberculina, destacando-se a utilizada por Seibert em 1949, que obteve o produto denominado Derivado Proteico Purificado (PPD) ${ }^{34,197,228,236}$. Culturas de cepas do bacilo da tuberculose em meio líquido sintético foram inativadas, filtradas, concentradas por ultrafiltração e precipitadas repetidamente com sulfato de amônio a 50\% ou ácido tricloroacético a $2 \%{ }^{34,197}$. Os PPDs, assim obtidos, são constituídos em grande parte de compostos puros e contém uma variedade de proteínas não sensibilizantes, de baixo peso molecular (10.000), denominadas tuberculoproteínas, que constituem o alergeno específico; além de lipídios, açúcares e ácidos nucléicos e incluindo uma grande variedade de antígenos, muitos dos quais comuns a várias espécies de micobactérias 197,228 .

No homem, os organismos infectados com o M.tuberculosis tornam-se sensíveis à tuberculina. Essa manifestação foi denominada "alergia tuberculínica" pelos autores franceses e "hipersensibilidade" pelos ingleses. A tuberculina não é um antígeno, pois não produz anticorpos em organismos virgens de infecção tuberculosa; é um partígeno (hapteno). Só produz reações na derme quando há infecção pelo M.tuberculosis e tendo-se desenvolvido a alergia tuberculosa (hipersensibilidade) ${ }^{236}$.

Deve-se lembrar que ela não permite distinguir o indivíduo apenas infectado do doente. Em áreas onde a vacinação BCG é feita rotineiramente, sua interpretação pode ser prejudicada. Seu valor é maior em pessoas não vacinadas com BCG ou naquelas vacinadas há longa data, já que a memória linfocitária perde-se em alguns anos 191,193 .

Há, porém, duas eventualidades em que ela sugere fortemente estado de tuberculose-doença. A primeira é quando uma criança de tenra idade se apresenta tuberculina-positiva, e a segunda é quando um indivíduo conhecido como anérgico passa a responder à tuberculina (viragem tuberculínica). Em ambos os casos, está se instalando a primoinfecção, cujo processo em desenvolvimento é imprevisível ${ }^{236}$. 
Apesar dos processos de purificação, ainda não se conseguiu isolar das espécies micobacterianas uma tuberculina específica para cada espécie. Por isso, a tuberculina do M.tuberculosis produz reações cruzadas de mesma intensidade nos organismos infectados pelo M.bovis, sendo impossível distinguir os infectados com o bacilo humano dos infectados com o bacilo bovino. Evidente, pois, que os vacinados com BCG (originado do M.bovis) reajam com a tuberculina do bacilo humano, variando a intensidade com o método de vacinação (a via intradérmica produz alergia tuberculínica mais alta que a via oral). A tuberculina produz reações cruzadas com os infectados por MOTT, sendo, porém, de fraca intensidade. Descreveram-se reações cruzadas com brucelose e actinomicose ${ }^{236}$.

Com o objetivo de fornecer aos epidemiologistas do mundo inteiro um produto de atividade uniforme, o Statens Serum Institute de Copenhaguem, por encargo da OMS, preparou um lote de 650g de PPD e iniciou, em 1958, a distribuição mundial do produto já diluído, em veículo especial com Tween 80 , que impede a adsorção das tuberculoproteínas ao vidro, estabilizando a atividade do alergeno durante, pelo menos, 6 meses a $0^{\circ} \mathrm{C}$. Esta preparação é denominada PPD RT23-2UT (RT = Renset Tuberculin; 23 = o número da partida; 2UT = 2 Unidades de Tuberculina, sendo uma unidade igual a $0,04 \mu \mathrm{g})^{34,236}$.

Na prova tuberculínica, a tuberculina usada ainda é o PPD RT23, aplicada com a técnica de Mantoux, por via intradérmica no terço médio da face anterior do antebraço esquerdo, na dose de $0,1 \mathrm{ml}$, equivalente a $2 \mathrm{UT}$, cujo resultado guarda equivalência com 5UT de PPD-S, utilizada em alguns países 34, 191, 193, 236.

Quando conservada em temperatura entre 4 e $8^{0} \mathrm{C}$, a tuberculina mantém-se ativa por 6 meses. Não deve, entretanto, ser congelada, nem exposta à luz solar $\operatorname{direta}^{191,193 .}$

A leitura da prova tuberculínica é realizada 72 a 96 horas após a aplicação, medindo-se com régua milimetrada, o maior diâmetro transverso da área de induração palpável. O resultado é registrado em milímetros, originando a seguinte classificação: 
$\Rightarrow 0-4 \mathrm{~mm}$ - não reator - indivíduo não infectado pelo bacilo da tuberculose ou anérgico.

$\Rightarrow 5-9 \mathrm{~mm}$ - reator fraco - indivíduo infectado pelo bacilo da tuberculose ou por outras micobactérias, ou ainda vacinados com BCG.

$\Rightarrow 10 \mathrm{~mm}$ e mais - reator forte - indivíduo infectado pelo bacilo da tuberculose, que pode estar doente ou não, ou vacinados com BCG $^{93,191,193,236 .}$

O teste tuberculínico é o indicador mais seguro da situação epidemiológica da tuberculose. Quanto maior for o percentual de reatores fortes, mais elevada é a prevalência da infecção tuberculosa ${ }^{93,236}$.

A sensibilização dos animais à prova de diagnóstico imunoalérgico (reação de tuberculina) é a principal arma empregada na discriminação das fontes de infecção. A tuberculinização de todo gado do rebanho é a base do diagnóstico da tuberculose bovina $53,56,197,200,201,237,272,281,282$.

As primeiras pessoas a usarem o teste da tuberculina no gado foram Bang na Dinamarca e Gutmann na Rússia, em 1890. Em 1892, três veterinários americanos utilizaram a tuberculina para documentar a infecção do gado, e esta prática logo tornou-se o principal suporte para a determinação de rebanhos infectados ${ }^{92}$.

Moussu e Mantoux, em 1908, foram os primeiros a descreverem o teste intradérmico no gado, utilizando a prega caudal do animal (teste simples caudal) como local de aplicação ${ }^{197}$.

O teste intradérmico simples, na pele do pescoço do animal (teste simples cervical) foi considerado mais sensível que o da prega caudal na Europa, e tornou-se o teste oficial na Finlândia em $191{ }^{197}$.

O teste intradérmico duplo, utilizando tuberculina mamífera, foi o teste oficial no Reino Unido até 1947. O método consistia na aplicação de uma segunda dose de tuberculina no local da reação após 48 horas e a medida do aumento da espessura da pele, 24 horas mais tarde. Este teste não apresentou vantagens sobre o teste intradérmico simples ${ }^{2,197 .}$ 
O teste da tuberculinização comparada usando as tuberculinas mamífera e aviária foi introduzido na Grã-Bretanha em 1942, mas a substituição da tuberculina mamífera pela bovina, só aconteceu em $197{ }^{197}$. Entre os métodos de tuberculinização existentes, este é o mais utilizado e sua finalidade é a distinção entre o gado infectado com bacilos tuberculosos do tipo bovino, e aqueles sensibilizados por outras micobactérias. É uma reação comparativa cervical, que consiste na injeção intradérmica de $0,1 \mathrm{ml}$ de cada uma das tuberculinas bovina (cepa AN5, Rotterdam ou Valle) e aviária (cepa D4ER ou TB56) em locais separados (aproximadamente $12,5 \mathrm{~cm}$ de distância) na pele do pescoço do animal, com observação e medida da induração ou protuberância, 72 horas após a inoculação, e as reações comparadas $56,57,73,85,148,168,197,200,201,204,214,228,237,281$.

Considera-se a reação positiva, quando a diferença da induração é $4 \mathrm{~mm}$ ou mais para a tuberculina bovina, ou seja, quando a reação bovina é mais que $4 \mathrm{~mm}$ maior que a reação aviária, ou quando sinais clínicos como edema, exudação, necrose ou dor estiverem presentes no local da aplicação da tuberculina bovina. Um resultado inconclusivo é obtido quando a reação bovina é de 1-4mm maior que a reação aviária e não há sinais clínicos no local da aplicação. E, um resultado negativo é o que apresenta uma reação bovina negativa, ou uma reação bovina positiva ou inconclusiva, que seja igual ou menor que uma positiva ou inconclusiva reação aviária, na ausência de sinais clínicos locais 56, 57, 85, 148, 197, 201, 214, 228, 237, 240, 281.

Foi escolhida a tuberculina aviária, porque além dela reduzir o número de reações falso-positivas, as quais podem ocorrer devido à sensibilização cruzada pelo M. avium-intracellulare, uma infecção relativamente comum no gado, mas que não resulta em doença, ela também possui estreitos laços antigênicos com 0 Mycobacterium paratuberculosis e algumas outras micobactérias que igualmente são responsáveis por reações cruzadas com a tuberculina bovina 42, 56, 57, 73, 148, 197, 201, 214, 228, 237, 281 . Recentemente a M.cookii, uma micobactéria ambiental, originalmente isolada de um tanque de água na Nova Zelândia, foi capaz de sensibilizar bovinos frente à tuberculina bovina ${ }^{197}$.

No Brasil, o teste da tuberculinização comparada é utilizado após o monoteste 
clássico, aplicado na prega ano-caudal do animal, que constitui um método de triagem dos animais positivos e duvidosos. O teste comparativo demonstrou que numerosos animais condenados no monoteste inicial, reagiam mais intensamente à tuberculina aviária, indicando assim, que a primeira reação poderia ter sido inespecífica, durante a triagem ${ }^{168,200,204,267 .}$

Nas Américas, 10 países produzem a tuberculina (PPD) para o diagnóstico da tuberculose bovina: Argentina, Brasil, Canadá, Cuba, Estados Unidos, México, Paraguai, República Dominicana, Uruguai e Venezuela ${ }^{218}$.

A tuberculina deve ser armazenada em um lugar fresco, seco e escuro, preferencialmente entre 2 e $10^{\circ} \mathrm{C}$. Durante seu emprego no campo, deve-se ter o cuidado de não submetê-la a temperaturas extremas, e nem à luz do sol. Não deve ser usada depois do dia em que o frasco tenha sido aberto ${ }^{56}$.

Avaliações da sensibilidade do teste tuberculínico no gado apresentam uma variação de 32-99\%, enquanto a especificidade é estimada em 75,5-99,9\%, de acordo com o país onde é aplicado, mas na maioria deles a sensibilidade varia de $77-95 \%$ e a especificidade ultrapassa $99 \%$ 57, 197, 216.

Essa variação ocorre, porque alguns animais, ainda que infectados, não respondem aos testes tuberculínicos. Fatores como infecção recente, desnutrição, final de gestação e imunossupressão post partum, podem ocasionar resultados falsonegativos. O bovino recentemente infectado não reage à tuberculina, porque a reatividade ao teste só ocorre 30-50 dias após a infecção. Os bovinos com doenças severas ou generalizadas também podem não reagir à tuberculina. Este estado é conhecido como "anérgico" e as razões para a sua ocorrência são pouco conhecidas. Outros fatores como a dessensibilização do animal pela inoculação de altas concentrações do antígeno ou por tuberculinizações repetidas, uma deficiência do sistema imunitário, variações inerentes ao próprio teste ou variações na sua leitura e interpretação, também geram resultados falso-negativos 155 , 197, 200, 207, 216, 240.

Um pequeno número de reações não específicas pode ocorrer em animais tuberculinizados caracterizados como reatores, nos quais não são observadas lesões 
no abate. Para confirmar falso-positivos, é necessário que se faça uma inspeção post mortem muito minuciosa, o que frequentemente é de difícil execução em matadouro. As causas de reações inespecíficas incluem animais sensibilizados por M.avium, $M$ paratuberculosis ou micobactérias ambientais. A especificidade também pode ser afetada pela tuberculina, pelo tipo de teste utilizado e pelos critérios de interpretação adotados $155,197,207,216,240$.

Em virtude de que no bovino a infecção tuberculosa quase sempre leva ao desenvolvimento de doença progressiva, o que não acontece na maioria dos casos nos humanos, nos primeiros a resposta positiva à prova tuberculínica deve ser interpretada como infecção-doença e nos humanos somente como infecção, salvo em crianças de pouca idade ${ }^{8}$.

Kantor e col. (1993) ${ }^{155}$ desenvolveram na Argentina, um teste simples, rápido e de baixo custo, proposto por Larsson em 1988, que poderia ter um papel complementar ao teste da tuberculina, para detectar bovinos tuberculosos, inclusive os anérgicos, especialmente em áreas endêmicas com recursos escassos. Denominado "Teste do glutaraldeído", ele consiste em misturar amostras de sangue total de bovinos com uma solução aquosa de glutaraldeído a $1,25 \%$ e observar o tempo de gelificação do sangue, que é menor nos bovinos tuberculosos ${ }^{155}$.

A sensibilidade do teste foi de $85,4 \%$ e a especificidade $97,1 \%$, após a análise de amostras de sangue, provenientes de 390 bovinos. A especificidade diminuiu quando o teste foi aplicado em animais com evidência de outras doenças, que não a tuberculose ${ }^{155}$.

Para os animais selvagens, a tuberculinização comparada apresenta baixa sensibilidade e problemas práticos, como por exemplo, a leitura adequada do teste nesses animais 115,210 .

Em animais não domesticados e cativos em zoológicos e parques animais, o problema também é grande, porque não têm sido desenvolvidos procedimentos adequados para o teste tuberculínico em muitas espécies exóticas, necessitando-se de estudos para determinar a eficácia da tuberculina no diagnóstico da tuberculose 
nesses animais, além de métodos adicionais para a detecção da tuberculose animal 260, 261 . Portanto, o diagnóstico da tuberculose pelo teste tuberculínico não é eficaz em determinadas espécies animais, podendo ser positivo em alguns, sem que lesões sejam encontradas na necropsia ${ }^{240,243}$.

O teste da tuberculina em texugos apresenta pouca sensibilidade, e o fato de que os animais devam ser capturados novamente após 72 horas para a leitura do teste, torna essa técnica impraticável, ocorrendo o mesmo em relação aos gambás ${ }^{210}$.

O teste de tuberculina tem algumas deficiências quando aplicado em cervos devido a reatores falso-positivos e falso-negativos ${ }^{61,179,216}$. O desempenho do teste tuberculínico comparativo cervical em cervos é muito variável sob as condições naturais na Nova Zelândia, apresentando uma sensibilidade de 31 a $80 \%$ e especificidade de 61 a $88 \%{ }^{134}$.

Na tuberculinização de primatas não humanos, as doses de tuberculina são consideravelmente mais altas do que as utilizadas para o teste no homem (5mg de O.T. ou 0,0025mg de PPD em 0,05ml de diluente) e aplicadas na pálpebra ou no abdômen do animal. A leitura é feita entre 24 e 72 horas, observando-se edema, eritema, pápula, necrose e ulceração. A reação negativa é indicativa de ausência de doença ou anergia, devido ao estágio avançado da tuberculose ${ }^{271}$.

Acredita-se que os búfalos apresentem maior reatividade cutânea, sendo mais sensíveis que os bovinos ao teste tuberculínico. Foram descritos vários casos de reações inespecíficas, nos quais não puderam ser encontradas lesões na necropsia. Devido à severidade das reações tuberculínicas produzidas em búfalos, os parâmetros do teste em bovinos não se aplicam corretamente nessa espécie. A sensibilidade e especificidade do teste em bovinos também não é a mesma para búfalos $240,241,243$.

Nos suínos, o teste intradérmico consiste na inoculação da tuberculina aviária e bovina na pele da base da orelha direita e esquerda, respectivamente. Em alguns casos é usada a inoculação no dorso (região lombar) e na vulva. A sensibilização à tuberculina aviária em suínos pode significar a presença de lesões, pois micobactérias do complexo MAC, especialmente o M.intracellulare, são capazes de causar 
linfadenites tuberculosas. Por esta razão, resultados positivos para as tuberculoses bovina e aviária devem ser considerados, em primeira instância, como infecções por micobactérias, sendo necessária a comprovação da ocorrência de lesões em frigoríficos e exames laboratoriais para definir o diagnóstico ${ }^{215}$.

Os cães desenvolvem baixa e irregular reação à tuberculina, com frequentes resultados falso-negativos. Seria necessária uma maior concentração de PPD para a realização do teste, o que poderia causar uma reação de hipersensibilidade aguda no animal. Por isso, o teste da tuberculina em cães, é considerado inconclusivo e não confiável. Entretanto, alguns estudos foram realizados injetando-se BCG intradermicamente na área interna da coxa do animal, mas observou-se resultados falso-positivos devido à reações cruzadas com outras micobactérias ${ }^{60,131,187}$.

Nos gatos, não se recomenda o teste da tuberculina, porque as respostas à administração do PPD são freqüientemente inconsistentes ou transitórias ${ }^{131,157}$.

As cabras são sensíveis à tuberculina e o PPD bovino pode ser injetado na região cervical, mas um diagnóstico confirmatório é necessário, requerendo a positividade da cultura das lesões, porque o M.avium também produz tuberculose disseminada nessas espécies animais. O mesmo ocorre em relação aos carneiros ${ }^{261}$.

O cavalo é muito mais sensível ao teste tuberculínico do que os bovinos, podendo ocorrer reações anafiláticas no animal, e animais sadios, freqüentemente, reagem positivamente ao teste. Não existem informações definitivas sobre as causas da sensibilidade não específica à tuberculina neste animal ${ }^{37,261}$.

\subsection{2- NOVOS EXAMES DIAGNÓSTICOS}

Novos métodos diagnósticos de tuberculose vêm sendo testados com o intuito de acelerar a confirmação etiológica das micobactérias que possuem um tempo de crescimento prolongado. Com o advento da AIDS, formas disseminadas rapidamente progressivas de tuberculose e de outras micobacterioses, são encontradas com freqüência. Em contraste com o passado, quando a natureza crônica da doença 
tornava aceitável uma espera de 4 a 8 semanas para um resultado positivo na cultura, as apresentações disseminadas em imunodeprimidos exigem diagnóstico mais rápido. Há um esforço no sentido do desenvolvimento de novos métodos para cultura e identificação rápida do bacilo da tuberculose e de outras micobactérias, particularmente quando estas estão presentes no sangue, caracterizando uma doença disseminada ${ }^{192}$.

Técnicas imunológicas e não imunológicas têm sido avaliadas na busca de um método ideal, ou seja, com altas sensibilidade (capacidade de um teste fornecer um resultado positivo quando a pessoa é verdadeiramente doente) e especificidade (capacidade de um teste apresentar um resultado negativo quando a pessoa não é doente), baixo custo e realização rápida e simples ${ }^{191}$.

Recentemente, a rápida identificação de cepas de M.bovis tem sido facilitada pelo desenvolvimento de provas imunológicas com anticorpos monoclonais e provas de DNA, que permitem a identificação de membros do complexo Mycobacterium tuberculosis, o qual inclui o M.bovis, em menos de um dia; mas os isolamentos ainda necessitam ser submetidos aos testes bioquímicos convencionais para confirmar sua identidade ao nível de espécies ${ }^{78}$.

Entre os novos exames diagnósticos destacam-se o método radiométrico, cromatografia gás-líquida, métodos sorológicos e técnicas de biologia molecular 6, 142, 191, 193, 296.

\subsubsection{1- Método radiométrico (BACTEC)}

A limitação da cultura pode ser superada pela utilização do sistema radiométrico automatizado, BACTEC $460{ }^{50,142,236,264,277}$. Seu princípio consiste em medir a concentração de $\mathrm{CO}_{2}$ marcado com carbono 14, produzido pelas micobactérias através da metabolização do ácido palmítico presente no meio de cultura (7H12-A e 7H12-B) ${ }^{50,142,236}$. Estudos recentes mostraram que o tempo médio para detecção de micobactérias por este sistema, para espécimes com isolamento de M.tuberculosis e baciloscopias positivas, foi de 8 dias, em comparação 
com 19,4 dias dos meios de cultura convencionais ${ }^{142}$.

As micobactérias cultivadas, tanto nos meios de culturas convencionais como no sistema BACTEC, devem ser submetidas à identificação da espécie ou do complexo de espécies ${ }^{93,142,192 .}$

\subsubsection{2- Cromatografia gás-líquida}

Baseia-se na análise de ácidos graxos de cadeia longa, realizada após saponificação dos lipídios micobacterianos ${ }^{50,192}$. O traçado obtido no cromatograma, a partir da amostra a ser identificada, é comparado com cromatogramas padrões de 26 espécies de micobactérias de importância clínica. É um método simples, rápido e reprodutível, que pode fornecer resultado em apenas 2 horas, porém exige equipamento sofisticado e pessoal altamente treinado ${ }^{192}$.

\subsubsection{3- Métodos sorológicos}

a) ELISA (Enzyme-linked immunosorbent assay) - O método sorológico baseia-se na resposta imune ao bacilo da tuberculose, e busca por meio dessa técnica de radioimunoensaio, antígenos específicos do bacilo ${ }^{191,296}$.

Uma das primeiras tentativas de obter um diagnóstico rápido da tuberculose humana foi o emprego da sorologia, ainda no início do século, muito antes do advento da $\operatorname{AIDS}^{192}$. A partir de 1972, com a descrição do teste imunoenzimático (ELISA), estudos foram realizados utilizando microrganismos íntegros, como o BCG, ou antígenos altamente purificados como o PPD, sulfolipídios, proteínas, e outros. Esses estudos mostraram que deveria ser quantificada IgG específica e que a pesquisa de IgM não era adequada para o diagnóstico ${ }^{192,233}$.

O teste de ELISA é largamente utilizado em doenças infecciosas, facilmente automatizado e de baixo custo. É realizado sobre suporte sólido (placas de poliestireno) adsorvido com antígeno. Outra alternativa é utilizar tiras de 
nitrocelulose como suporte, DOT-ELISA, que requer menor quantidade de soro e de reagentes, e a leitura pode ser visual ${ }^{192}$.

O principal obstáculo ao método tem sido a identificação de um antígeno específico, puro, só presente no bacilo da tuberculose. As principais conclusões disponíveis sobre o método de ELISA são que, dependendo do antígeno utilizado, a sensibilidade e especificidade são elevadas, principalmente a última; o teste é mais sensível nos doentes com formas pulmonares avançadas e menos sensível nas lesões paucibacilares e/ou extrapulmonares; a sensibilidade é proporcional à prevalência da doença na região; os títulos de anticorpos aumentam com o tempo de evolução da doença e não se modificam em populações submetidas à vacinação BCG em massa. A literatura registra sensibilidade e especificidade variando, respectivamente, de 40 a $95 \%$ e 80 a $110 \%{ }^{191,192}$.

No Brasil, poucos trabalhos foram realizados para o diagnóstico da tuberculose em pacientes com AIDS, através de sorologia. Em estudo no Rio de Janeiro, a sensibilidade do teste em pacientes com tuberculose e AIDS foi de 0 a $25 \%$ dependendo do antígeno utilizado, enquanto que nos pacientes tuberculosos imunocompetentes a positividade obtida foi de 60 a 70\%. Em pacientes infectados pelo HIV ou com AIDS, a falta de imunidade humoral ou respostas inusitadas, como ativação policlonal, levam a resultados desanimadores quanto à aplicação da sorologia no diagnóstico rápido da tuberculose ${ }^{192}$.

Estão sendo desenvolvidos testes de ELISA, utilizando anticorpos monoclonais para a identificação do M.bovis, que têm se revelado de fácil execução, de baixo custo e, portanto, mais acessíveis para os laboratórios das regiões com alta prevalência de tuberculose bovina ${ }^{7}$.

Um anticorpo monoclonal, denominado 4C3/17 tem apresentado uma alta especificidade para o M.bovis. Este anticorpo reconheceu todas as 156 cepas de M.bovis utilizadas em um estudo e também alguns outros membros do complexo M.tuberculosis, como 6 das 7 cepas BCG e 12 das 14 cepas de M.tuberculosis. Nenhuma outra espécie de micobactéria ou outro gênero examinado ligou-se ao anticorpo, demonstrando $100 \%$ de especificidade para o complexo M.tuberculosis. 
Uma técnica DOT-ELISA usando este anticorpo para a identificação do M.bovis, está sendo desenvolvida, com a obtenção do resultado em 2 a 3 horas ${ }^{78}$.

O teste de ELISA para os bovinos é menos específico que o teste tuberculínico, e de baixa sensibilidade para detectar animais tuberculosos nos estágios iniciais da doença, quando a infecção ainda é inaparente. O teste só é sensível para animais com lesões macroscópicas aparentes, não podendo ser aplicado como único recurso diagnóstico para a tuberculose bovina. Quando muito, poderá ser útil no início das campanhas de controle, como um exame complementar, para identificar animais com doença avançada, que seriam eliminados como a principal fonte de infecção do M.bovis $156,233,234,293,294$.

Apesar do pouco conhecimento a respeito da resposta imune dos texugos frente à doenças infecciosas, um teste de ELISA indireto usando o antígeno $25 \mathrm{kDa}$ (forma glicosilada do MPB70) para o sorodiagnóstico de M.bovis, tem sido desenvolvido. Este antígeno tem sido descrito como imunodominante em texugos infectados com M.bovis e conservado em todas as cepas testadas em campo. Este ELISA teve uma especificidade de $98 \%$ e uma sensibilidade de apenas $37 \%$. A sensibilidade pode ter sido influenciada por inúmeros fatores, incluindo a idade, sexo e o status da doença no animal ${ }^{123}$. Contudo, a sensibilidade foi maior que os atuais métodos de amostragem clínica, os quais detectam apenas 20\% de texugos infectados $123,124,216$.

$\mathrm{O}$ antígeno $25 \mathrm{kDa}$, foi considerado um potencial candidato para $\mathrm{o}$ desenvolvimento de um teste de campo específico para o sorodiagnóstico da infecção por M.bovis nesses animais, uma vez que, o pré-requisito para o desenvolvimento de um novo teste é que o antígeno seja específico para o M.bovis e imunogênico durante a infecção no texugo ${ }^{123,124}$.

A sensibilidade do ELISA foi muito maior quando usado em grupos de texugos no sudeste da Inglaterra. O teste de ELISA identificou tuberculose em 74\% dos grupos que eram positivos na cultura; entretanto, 30\% dos grupos culturanegativos eram ELISA-positivos, resultando em uma especificidade do teste de $70 \%{ }^{216}$. 
No sudoeste da Inglaterra, o teste de ELISA tem falhado em identificar aproximadamente $25 \%$ dos setts ocupados por texugos infectados com M.bovis, por esse motivo, todos os texugos pegos em armadilhas nas fazendas atingidas, e onde opiniões de veterinários implicam esses animais como fontes de infecção são mortos sem o uso do teste de ELISA ${ }^{216}$. A sensibilidade do teste na investigação de 177 texugos naturalmente infectados com M.bovis, sujeitos a rotina das operações de controle, foi de apenas $35 \%$ para adultos e $60 \%$ para os filhotes ${ }^{286}$.

Um teste de ELISA comparativo foi desenvolvido pelo Deer Research Laboratory, da Universidade de Otago, Nova Zelândia, para detectar tuberculose bovina em animais, principalmente cervos. Este teste compara a reatividade da amostra de soro aos antígenos do Derivado Protéico Purificado do M.avium (PPDa), M.bovis (PPDb) e da proteína específica do M.bovis (MPB70) purificada, sendo possível obter uma sensibilidade de $86 \%$ e uma especificidade de $98 \%{ }^{115}{ }^{134}$. As leituras da densidade ótica para os diferentes antígenos, são medidas em soros diluídos a 1:40. Valores com PPDb ou MPB70 iguais ou maiores que 0.2 unidades, por comparação com PPDa, são considerados positivos ${ }^{115}$.

A resposta imune humoral frente a tuberculose ocorre mais cedo nos cervos do que em humanos, por isso o ELISA é uma poderosa ferramenta para diagnosticar tanto os animais com um baixo grau de infecção como os portadores de doença avançada $^{134}$.

Um teste de ELISA competitivo, para o diagnóstico da tuberculose em cervos, vem sendo desenvolvido na Inglaterra desde 1994, e envolve a competição entre anticorpos específicos de M.bovis em soro de cervo infectado e anticorpos monoclonais específicos de M.bovis, provenientes de camundongos, e conjugados com enzimas. Enquanto esta técnica apresenta uma alta especificidade (100\%), sua sensibilidade inferior a 50\% torna-a não confiável como teste para diagnóstico de tuberculose em cervos, uma vez que, quando o teste é positivo pode-se afirmar que o animal é um portador de infecção tuberculosa, mas, quando negativo, não se pode confiar que a doença esteja ausente ${ }^{134}$. 


\section{b) Teste de gama-interferon ( finterferon test)}

Este tipo de teste in vitro detecta imunidade celular aos antígenos das tuberculinas (PPD) bovina e aviária em amostras de sangue heparinizado ${ }^{87,112,156,207,291,294}$. Baseia-se na detecção da $\gamma$-interferon, liberada pela sensibilização dos linfócitos durante incubação com tuberculina ${ }^{112,156,291,294}$. Esta incubação usando o sangue total heparinizado com o antígeno é seguida por um anticorpo monoclonal, baseado em um teste imunoenzimático para $\gamma$-interferon. Este teste tem sido aplicado para o monitoramento de respostas imunocelulares no bovino, carneiros, cabras e búfalos, e considerado mais sensível que o teste da tuberculina, para detectar tuberculose no gado $87,112,207,291,292,293,294$. Ele detecta um significante número de bovinos nos estágios iniciais da infecção por M.bovis, e que tenham falhado na resposta ao teste tuberculínico ${ }^{112,207,292 .}$

A vantagem sobre o teste de pele, é que os animais precisam ser capturados apenas uma vez, mas as sérias desvantagens são o alto custo e o fato de que o processamento das amostras de sangue tem que ser iniciado com 8 horas de coleta 295. Além disso, este teste deve ser melhor avaliado em relação à sua sensibilidade e especificidade no campo, em uma população bovina local, antes de ser utilizado com maior freqüência 112, 207, 292, 293, 294.

\section{c) Teste de transformação do linfócito (Lymphocyte transformation test)}

Este teste mede a reatividade celular dos linfócitos T-imunes, in vitro, e foi desenvolvido também pelo Deer Research Laboratory, na Nova Zelândia, como um sensível marcador para tuberculose em cervos. Possui a vantagem de poder detectar precocemente a doença em seu curso natural e com um alto grau de sensibilidade $(95 \%)$ e especificidade $(92 \%)^{115,134}$.

Entretanto, ele não tem sido avaliado quanto à sua aplicação sob as condições de campo, devido à dificuldade na automação de um sistema de cultura estéril e à necessidade de execução de detalhados estudos longitudinais. Estes fatores atuam 
como um desestimulante para promover o aperfeiçoamento desta técnica ${ }^{134,294}$.

Apesar dos problemas ainda não resolvidos, esse recente progresso baseado em microtécnicas simples e eficientes poderia oferecer significativas vantagens operacionais sobre o teste da tuberculina, pois eliminariam o duplo movimento do gado e veterinários; poderiam ser parcialmente ou totalmente automatizados, reduzindo variações inter-experimentais e permitindo a estocagem de amostras que seriam utilizadas para diferentes propósitos diagnósticos; poderiam complementar ou substituir o teste tuberculínico em campanhas de controle e erradicação da tuberculose bovina, desde que provassem sua efetividade sob condições de campo e os custos fossem baixos, os procedimentos simples, e os reagentes estáveis ${ }^{156}$.

Certamente, a aplicação do teste e o método de abate do animal em escala nacional, nos países com alta prevalência da doença, poderiam eliminar um número significante de animais em um curto período de tempo. Entretanto, estes testes necessitam de avaliações mais profundas para que sua utilidade seja determinada em cada situação epidemiológica particularmente. A coordenação técnica entre os países e agências de cooperação internacional poderia desempenhar um importante papel na realização deste objetivo ${ }^{156}$.

\subsubsection{4- TÉCNICAS DE BIOLOGIA MOLECULAR}

Os recentes avanços na área da Biologia Molecular permitiram o desenvolvimento de métodos para a identificação de algumas espécies ou complexos de micobactérias que envolvem a detecção de sequências de DNA cromossômico ou RNA ribossômico, específicas dessas micobactérias ${ }^{142}$.

A tecnologia atual de Biologia Molecular tornou-se possível graças à identificação e purificação de um grupo de enzimas nucleares, descritas abaixo:

- Ligase - Une fragmentos de DNA;

- Transferase terminal - Acrescenta nucleotídeos à extremidade de uma fita de 
DNA;

- RNA polimerases - Transcrevem o DNA em RNA;

- DNA polimerases - Replicam fragmentos de DNA;

- Transcriptase reversa - Sintetiza uma fita de DNA a partir de RNA;

- Endonucleases de restrição - Clivam DNA em pontos específicos;

- Taq polimerase - Replica DNA; termoestável.

Desde 1944, foi estabelecido que a informação genética está contida em longos polímeros de ácido desoxirribonucléico (DNA). A unidade fundamental do DNA é o nucleotídeo, que é composto de um açúcar especial (desoxirribose), uma base púrica ou pirimídica, e uma molécula de fosfato. As enzimas que agem sobre o DNA são as DNA polimerases e RNA polimerases. A estrutura tridimensional do DNA é complexa, associando-se duas fitas em disposição helicoidal em torno do mesmo eixo. Os resíduos de fosfato e açúcar ficam expostos do lado externo, enquanto as bases de uma fita interagem com as da fita oposta na parte interna da hélice. A interação entre as bases de duas fitas opostas é específica, sendo mantida por pontes de hidrogênio. Uma molécula de adenina pareia-se a uma molécula de timina, enquanto uma guanina pareia-se a uma citosina. Estas interações específicas formam a base da complementariedade de duas fitas de DNA ${ }^{6}$.

A mensagem genética do DNA é transcrita para RNA ainda sob a forma de seqüência de nucleotídeos e este processo é realizado pelas RNA polimerases, que sintetizam uma molécula de RNA complementar a um determinado segmento de DNA, ou seja, um polímero com nucleotídeos complementares ao trecho de DNA copiado. O RNA diferencia-se do DNA por ter a ribose como açúcar, apresentar a base uracila em lugar da timina, e ser constituído de fita única. Toda a informação para a codificação de uma proteína ou RNA, está contida em uma unidade genética denominada gene ${ }^{6}$.

As bases técnicas em Biologia Molecular são: 


\section{a) Separação eletroforética de moléculas e transferência para fase sólida}

A separação de moléculas de acordo com sua carga elétrica e peso molecular por meio de uma corrente elétrica, conhecida como eletroforese, têm sido progressivamente aperfeiçoados por avanços técnicos no suporte sobre o qual estas moléculas são separadas. Algumas formas muito utilizadas incluem a separação de proteínas em gel de poliacrilamida, ácidos nucléicos em gel de agarose e RNA em gel de poliacrilamida/uréia. Esta metodologia permite a discriminação de uma grande variedade de proteínas ou segmentos de ácidos nucléicos presentes em uma amostra, e ainda, a determinação de seu peso molecular ${ }^{6}$.

Entretanto é difícil obter informações adicionais, pela dificuldade em se trabalhar com suportes semi-sólidos, como géis. Um grande avanço ocorreu com a descoberta de que é possível transferir quantitativamente o material separado por eletroforese em gel para um suporte sólido, como, por exemplo, um filtro de nitrocelulose ou membranas de náilon ${ }^{6}$.

A transferência de fragmentos de DNA previamente separados em gel de agarose foi desenvolvida em 1976 por Southern, sendo conhecida como Southern blot. Seguiu-se o desenvolvimento de técnicas para transferência de RNA (Northern blot) e de proteínas (Western blot). O processo de transferência fornece uma réplica perfeita do gel de separação. As diferentes moléculas de uma amostra, imobilizadas em bandas horizontais no suporte sólido, podem então ser estudadas quanto à sua natureza. As proteínas podem ser investigadas quanto à sua antigenicidade (sondas com anticorpos) e os ácidos nucléicos quanto à sequência de aminoácidos (por hibridização com seqüências conhecidas) ${ }^{6}$.

\section{b) Hibridização de ácidos nucléicos}

A estrutura do DNA sofre uma desnaturação em temperaturas próximas de $100^{\circ} \mathrm{C}$, ou em pH alcalino, havendo a separação das fitas. Essa desnaturação é reversível, e ao se resfriar a solução a cerca de $50^{\circ} \mathrm{C}$ as duas fitas pareiam-se novamente, seguindo o princípio da complementariedade das bases. Durante a 
renaturação, as fitas tanto podem ligar-se às mesmas fitas às quais estavam ligadas previamente, como podem parear-se a qualquer outra seqüência de nucleotídeos, mesmo que seja RNA, desde que haja complementaridade de bases. Este fenômeno é denominado hibridização de ácidos nucléicos, sendo largamente utilizado em Biologia Molecular ${ }^{6}$.

Uma aplicação comum da hibridização de ácidos nucléicos é a identificação de um determinado segmento gênico em uma amostra. Procede-se à desnaturação da amostra seguida de incubação com uma sonda complementar ao seguimento gênico de interesse. A sonda pode consistir de oligonucleotídeos sintéticos ou fragmentos de DNA complementar. Em ambos os casos, alguns dos nucleotídeos da sonda serão marcados com fósforo radioativo $\left(\mathrm{P}^{32}\right)$ ou enzimas. Caso haja na amostra o segmento gênico procurado, a sonda irá hibridizar especificamente e será detectada em autoradiografia. Há uma tendência recente ao emprego de nucleotídeos marcados com compostos luminescentes, como a digoxigenina, que não teriam os inconvenientes inerentes ao uso de radioisótopos $6,142,192$.

A hibridização com sondas marcadas é, freqüentemente, empregada na identificação dos fragmentos de DNA e de moléculas de RNA separadas e imobilizadas pelas técnicas de Southern e Northern blot, respectivamente ${ }^{6,73}$.

\section{c) Clonagem de DNA}

O termo clonagem de DNA refere-se à purificação quantitativa de um determinado fragmento de DNA. Obtém-se assim, milhões de moléculas de DNA com sequiência idêntica de nucleotídeos. O material genético a ser clonado é apresentado sob a forma de "bibliotecas de DNA", que são um conjunto de fragmentos de ácido nucléico, representativos de todo o DNA de um determinado organismo. Os fragmentos de DNA de uma biblioteca estão inseridos em microrganismos auto-replicantes denominados vetores, através dos quais é feita toda a manipulação da biblioteca. Em geral representados por plasmídeos e bacteriófagos, os vetores parasitam bactérias (E.coli sensíveis a ampicilina) e utilizam seu 
maquinário enzimático para replicação. No processo, o fragmento de DNA da biblioteca, neles inserido, é também replicado ${ }^{6}$.

Existem bibliotecas de DNA genômico, que são formadas por grandes fragmentos de DNA cromossômico, que podem ser gerados por enzimas (endonucleases de restrição) ou por quebra física, fornecendo informações sobre todo o gene; e bibliotecas de DNA complementar, formadas a partir do RNA do tecido cujo material genético se quer estudar, que produzem pequenos fragmentos de DNA complementar, possibilitando sua inserção em plasmídeos e facilitando a manipulação ${ }^{6}$.

As bibliotecas de DNA devem ser rastreadas em busca do clone de vetores que contenha o fragmento desejado de DNA, o que é feito por meio de sondas apropriadas. O tipo de sonda mais sensível e específica é a sonda de oligonucleotídeos, que é uma sequiência de cerca de 20 nucleotídeos, alguns dos quais marcados radioativamente, sintetizada de forma a ser complementar a um trecho do gene que se quer clonar. A sonda irá hibridizar especificamente com o(s) clone(s) de vetores contendo trechos de DNA complementar a ela. É necessária alguma informação prévia sobre a seqüência do gene a ser clonado para se elaborar uma sonda de oligonucleotídeos ${ }^{6}$.

Quando não é possível elaborar uma sonda de oligonucleotídeos, pode-se utilizar anticorpos como sondas. Podem ser anticorpos de origem animal (poli ou monoclonais), ou auto-anticorpos humanos de ocorrência espontânea. Empregam-se vetores especiais, denominados vetores de expressão, especialmente construídos de modo a possibilitar a indução da síntese da proteína codificada pelo DNA complementar neles inserida. As colônias de bactérias contendo esses vetores apresentam grande quantidade de proteína recombinante, que pode ser detectada por anticorpos ${ }^{6}$.

Qualquer que seja a sonda utilizada, após a identificação do clone de interesse, o mesmo é replicado até que se consiga 100\% de clones positivos em uma placa. Procede-se então ao crescimento em larga escala do clone isolado, e posterior extração e purificação do DNA complementar. O DNA purificado pode ser utilizado 
para sequienciamento, elaboração de sondas radioativas, transfecção em outros organismos, transcrição e transdução in vitro, síntese maciça de proteína recombinante, obtenção de DNA complementar com deleções parciais (clones truncados) e recombinação com outros fragmentos de DNA complementar ${ }^{6}$.

\section{d) RFLP (restriction fragment length polymorphism) e Endonucleases de restrição}

RFLP é a sigla inglesa relativa a polimorfismo do tamanho dos fragmentos gerados por endonucleases de restrição, que são enzimas bacterianas com a propriedade de clivar moléculas de DNA estranho, que porventura penetrem a célula $^{6,73}$. Representam, portanto, uma defesa primitiva de organismos não nucleados. A clivagem da dupla hélice de DNA ocorre em pontos conhecidos como sítios de restrição, que são seqüências de 4 a 8 nucleotídeos, específicas para cada enzima ${ }^{6}$. Esta técnica produz um padrão de fragmentos, ou "fingerprint", o qual caracteriza unicamente a cepa da qual o DNA foi isolado ${ }^{73}$.

Há uma grande variedade de enzimas de restrição que reconhecem uma ampla gama de sítios de restrição. A distribuição dos sítios de restrição num determinado gene é específica para a endonuclease em questão, e função da seqüência de nucleotídeos do gene. Este é o princípio em que se baseia a técnica de RFLP ${ }^{6}$.

O estudo do RFLP envolve técnicas de digestão de DNA, separação eletroforética Southern blot e hibridização de ácidos nucléicos. A amostra de DNA a ser estudada é inicialmente digerida por uma ou mais endonucleases de restrição e separada eletroforeticamente em gel de agarose. Após transferência para nitrocelulose (Southern blot), o filtro é incubado com sonda radioativa complementar a segmentos do gene de interesse. A hibridização da sonda acusará os fragmentos de restrição do gene em questão. Como a distribuição dos sítios de restrição em um gene depende da seqüência de nucleotídeos, o tamanho e número dos fragmentos gerados obedecerão às variações na seqüência de nucleotídeos. Esta variação pode ser normal no caso de regiões polimórficas do genoma, ou pode traduzir uma mutação específica no caso de 
genes monomórficos, os quais não exibem variações individuais na sua sequiência de nucleotídeos ${ }^{6}$.

Uma grande parte dos estudos utilizando RFLP não analisa diretamente o gene de interesse, e sim regiões polimórficas vizinhas, para as quais existem mapas de restrição definidos. Como segmentos próximos de DNA tendem a ser segregados conjuntamente durante a meiose de células germinativas, a análise de regiões polimórficas fornece informação indireta sobre os genes vizinhos ${ }^{6}$.

Para detectar o bacilo de Koch, basta uma região do cromossoma, que pode ser o IS6110 que está presente unicamente no bacilo de Koch. Também mediante a característica genética dos bacilos, estudando-se o seu DNA com enzimas de restrição que o cortam em pontos precisos, pode-se saber se os bacilos procedem da mesma fonte de contágio ${ }^{50}$. Um número de diferentes sequiências de DNA, as quais são repetidas muitas vezes no genoma, têm sido usadas para detectar uma quantidade adequada de fragmentos, para análise pelo RFLP ${ }^{86}$.

Sondas de ácido nucléico para a identificação do complexo M.tuberculosis e, especificamente M.tuberculosis, estão disponíveis, mas nenhuma sequiência única de ácido desoxirribonucléico (DNA) para o M.bovis foi encontrada 17, 128, 140, 196, 252. Portanto, a identificação do M.bovis por métodos moleculares ainda é complicada. Um dos elementos repetitivos, a seqüência de inserção IS6110 isolada do M.tuberculosis é encontrada em todos os membros do complexo M.tuberculosis. Enquanto as cepas de M.tuberculosis, freqüentemente, têm múltiplas cópias desta sequiência (de 1 a 19), as de M.bovis usualmente têm apenas uma ou no máximo 6 cópias, mas exceções ocorrem. Assim, algumas cepas de M.tuberculosis têm apenas uma ou nenhuma, e algumas cepas de M.bovis, isoladas de animais selvagens e alguns humanos, têm múltiplas cópias ${ }^{17,86,140,196,252,254}$.

Outra seqüência de inserção, a IS1081 isolada do M.bovis, encontra-se repetida 6 vezes no M.bovis, mas falhou em discriminar diferentes cepas dessa micobactéria, quando usada em provas pelo RFLP ${ }^{86}$.

Informações publicadas sobre o desenvolvimento de técnicas moleculares, 
tem indicado que organismos contendo as seqüências de inserção IS986 e IS1081 pertencem ao complexo M.tuberculosis, e aqueles contendo o gene mpt40 são M.tuberculosis. Ao menos uma proteína específica do M.bovis, a MPB70 já tem sido descrita, apesar desse gene estar presente também no complexo M.tuberculosis ${ }^{133,140,171,216,275,295,296}$. A proteína MPB70 tem sido empregada como antígeno e utilizada para diferenciar vacinação de doença natural, uma vez que ela é encontrada em animais naturalmente infectados, principalmente cervos, e ausente em animais vacinados com $\mathrm{BCG}^{133}$.

O RFLP foi utilizado no período de 9 de dezembro de 1985 a 21 de fevereiro de 1986, em Hutt Valey, na Nova Zelândia, para esclarecer um surto de infecção por M.bovis em 12 gatos de 3 clínicas veterinárias da região ${ }^{73,178 .}$

A análise pelo RFLP demonstrou que todas as cepas de M.bovis eram idênticas. Este fato poderia explicar a presença de uma cepa de M.bovis específica para felinos, a existência de uma cepa predominante nos animais selvagens de Hutt Valey, ou uma comum, mas não identificável fonte de infecção. Apesar de terem sido realizadas análises de restrição em mais de 40 cepas de M.bovis de gambás, bovinos, suínos e cervos da região, não foi encontrada outra cepa semelhante à dos gatos ${ }^{73,178}$.

A explicação mais provável foi de que um gato infectado trouxe essa cepa para uma das clínicas, possivelmente adquirida de outro animal, e de algum modo ela foi transmitida a outros gatos que a visitaram ${ }^{73,178}$.

No período de 1991 a 1994, foram identificados 10 rebanhos de cervos infectados por M.bovis, na Suécia, que haviam tido contato com cervos importados do Reino Unido em 1987. Análises pelo RFLP indicaram que 8 cepas de M.bovis isoladas de 5 rebanhos, possuíam o mesmo padrão de fragmentos de DNA de 2 cepas britânicas, sugerindo uma fonte comum de infecção ${ }^{40}$.

Na Argentina, em 1993, ocorreu tuberculose por M.bovis em 4 focas e 1 leão marinho, sendo que o DNA genômico de todos os 5 isolamentos foi analisado pela técnica RFLP, usando a sonda IS6110 e encontrando-se cepas de M.bovis diferentes das cepas isoladas dos bovinos argentinos $216,254$. 
Em 1994, pesquisadores de Stormont, na Austrália, registraram o uso da técnica RFLP no exame de 108 isolamentos de M.bovis em bovinos e de 1 isolamento em um cervo, na Irlanda do Norte, obtidos de culturas realizadas no período de 1989 a 1993. Foram usadas 3 diferentes sondas de DNA, a IS6110, IS1081 e pTBN12, que identificaram 10, 2 e 12 padrões diferentes, respectivamente. Por combinação dos padrões gerados pelas 3 provas, foi possível identificar 28 tipos diferentes de RFLP. A cepa de M.bovis proveniente do cervo, também foi encontrada no bovino 216,252 .

Em 1994, pesquisadores na Holanda realizaram a análise de 153 cepas de M.bovis de bovinos, de várias espécies animais de zoológicos e parques de animais selvagens e de humanos, usando 3 diferentes marcadores genéticos. Cepas de M.bovis isoladas do gado apresentavam caracteristicamente um só elemento IS6110, enquanto que a maioria das cepas de outros animais, como os antílopes, macacos e focas, abrigavam múltiplos elementos IS6110, sugerindo que os reservatórios de M.bovis nos bovinos e animais exóticos cativos, eram diferentes. Neste estudo, foram apresentadas evidências de que na Holanda, a infecção pelo M.bovis em humanos era contraída, principalmente, de animais outros que os bovinos ${ }^{216,254}$.

Em 1995, foram analisadas 40 cepas de M.bovis provenientes de bovinos e cabras, na Espanha, sendo 17 cepas de bovinos e 23 de cabras. Todas as cepas das cabras testadas pelo RFLP, apresentaram 6 a 8 cópias diferentes da seqüência de inserção IS6110, enquanto 16 das 17 cepas dos bovinos apresentaram uma única cópia de IS6110. Concluiu-se que as cepas de M.bovis que estavam causando tuberculose nos bovinos e cabras espanholas não eram as mesmas, e conseqüentemente, os reservatórios para as tuberculoses bovina e caprina, eram diferentes. Não foi possível distinguir se a preferência pelo hospedeiro por essas cepas, foi devida à falta de transmissão da doença entre esses animais ou à variações na virulência dessas cepas nos diferentes hospedeiros ${ }^{140}$. Em 1996, um estudo realizado também na Espanha, revelou que 51\% das cepas de M.bovis, isoladas dos bovinos espanhóis, abrigavam múltiplas cópias de IS6110 ${ }^{17}$.

Usando as 2 sondas mais estáveis como marcadores genéticos (IS6110 e 
IS1081), específicas para o complexo M.tuberculosis, análises RFLP identificaram 6 tipos de genes de um total de 22 diferentes isolamentos de M.bovis, obtidos de animais e humanos na República da Irlanda. Os 22 isolamentos de M.bovis, sujeitos à tipificação RFLP, eram de 4 humanos, 8 bovinos, 7 texugos, 2 carneiros e 1 cervo. Usando a sonda IS6110, 5 tipos de genes foram identificados e usando a IS1081, 2 tipos de genes. Os resultados associados usando as 2 sondas, identificaram 6 tipos de genes ${ }^{216}$.

Surtos epidêmicos de tuberculose causados por mais de um tipo de cepa de M.bovis, sugere múltiplas fontes de infecção, possivelmente por causa da compra de animais infectados de outras propriedades, ou infecção simultânea de rebanhos vizinhos, ou reservatórios selvagens. A freqüente movimentação de animais entre fazendas, em uma pequena área geográfica, é comum na Irlanda do Norte e a transmissão inter-bovinos é reconhecida como altamente significante na manutenção da doença na população bovina. Por isso, a tipificação de cepas de M.bovis pela técnica do RFLP, em conjunção com o registro e observação dos movimentos dos bovinos entre as propriedades, poderá ser extremamente útil em elucidar a epidemiologia da tuberculose bovina em diferentes países ${ }^{252}$.

Mais de 800 cepas de M.bovis estão sendo examinadas por esta técnica, desde 1995, incluindo 143 cepas de cervos, 247 de bovinos, 96 de suínos e um grande número de muitas espécies de animais selvagens. A grande maioria dessas cepas é proveniente da Nova Zelândia, mas cepas da Irlanda, África do Sul, Austrália e Reino Unido também têm sido investigadas. Mais de 90 tipos diferentes de restrição têm sido obtidos e não há evidências de qualquer cepa específica para um determinado hospedeiro ${ }^{40}$.

Como demonstrado em várias pesquisas, o RFLP poderá ser, futuramente, uma ferramenta muito útil na epidemiologia da tuberculose, para estudar a transmissão do M. tuberculosis e M. bovis entre animais e humanos ${ }^{295,} 296$.

\section{e) Análise da endonuclease de restrição (REA - Restriction Endonuclease}




\section{Analysis)}

Este método baseia-se na técnica de RFLP e consiste na habilidade de endonucleases de restrição, cortarem o DNA em pontos onde existem uma certa seqüência pequena de bases. Esse processo gera um número de fragmentos de DNA de diferentes tamanhos, os quais podem ser separados de acordo com seu peso molecular, pela eletroforese em ágar-gel de alta resolução ${ }^{125}$.

Um dos maiores retrocessos no estudo epidemiológico da propagação da infecção por M.bovis entre animais e homens, e particularmente entre bovinos, ou de animais selvagens para bovinos e vice-versa, tem sido a falta de um sistema confiável para a diferenciação de cepas ou sub-espécies de M.bovis. Nem a fagotipagem, e nem a biotipagem têm sido úteis, mas esperava-se que aumentassem sua utilidade pela aplicação da Restriction Endonuclease Analysis (REA) em estudos epidemiológicos na Nova Zelândia. Entretanto, registros iniciais indicaram que esta técnica não foi capaz de diferenciar 40 cepas de M.bovis de 8 rebanhos de gado, na República da Irlanda 86, 126, 216. Acredita-se que a cepas de M.bovis na Irlanda, sejam particularmente homogêneas e que as diferenças genéticas sejam muito pequenas, por isso, requerem análises sofisticadas de DNA para sua demonstração ${ }^{126}$.

A técnica foi adaptada para o estudo de micobactérias por Collins e col., do Laboratório de Referência em Saúde Animal na Nova Zelândia, para tipificar o bacilo da tuberculose bovina isolado de 83 gambás, cujos tecidos foram obtidos entre 1982 e 1984, provenientes de 3 principais regiões com tuberculose bovina endêmica. A digestão do DNA foi feita por 3 endonucleases - BstEII, PvuII e BclI e um total de 21, 14 e 14 padrões diferentes, respectivamente, puderam ser distinguidos na eletroforese. Por combinação de dados, um total de 33 tipos de restrição forneceu padrões de fragmentos idênticos aos obtidos originalmente. Esta grande similaridade entre os padrões de fragmentos de DNA dos isolamentos de M.bovis refletiu o alto grau de parentesco genético dessas cepas. Nenhuma das cepas foram encontradas em mais que uma das 3 regiões e muitas delas mostraram uma limitada distribuição geográfica em cada região $69,70,72,73,125$.

No período de 1982 a 1987, esse mesmo sistema de tipagem foi utilizado 
pelos mesmos pesquisadores, para investigar a transmissão da infecção por M.bovis entre diferentes espécies animais, nas mesmas 3 regiões da Nova Zelândia. Foram tipificadas 42 cepas de M.bovis isoladas de 30 bovinos, 7 gambás, 2 cervos selvagens, 2 porcos selvagens e 1 porco domesticado, além de 2 grupos de 18 e 12 bovinos, provenientes de 2 regiões menores, que apresentavam um grande número de gado tuberculina-positivo. Os tipos de restrição desses bovinos foram semelhantes aos padrões encontrados para os gambás da mesma área do estudo anterior ${ }^{70}$.

Nas 2 áreas menores, ocorreu um único tipo de restrição e as cepas de M.bovis encontradas nos cervos e porcos selvagens foram também encontradas nos bovinos e gambás, indicando que nesta área houve a transmissão, direta ou indireta, de uma única cepa entre as 4 espécies animais ${ }^{70}$.

Nas 3 áreas principais, todos os tipos de restrição do M.bovis encontrados nos animais selvagens no período de 5 anos de estudo, foram também encontrados nos bovinos em algum momento, durante a investigação ${ }^{70}$.

Estes estudos mostraram que animais selvagens e domésticos na mesma localidade, estavam infectados com a mesma cepa de M.bovis, e que cada tipo de restrição de M.bovis estava limitada a uma pequena área geográfica 69, 70, 72, 73, 125 . Concluiu-se que uma cepa foi mantida em uma localidade, provavelmente por muitos anos, infectando animais selvagens nessa área. Esses animais, dos quais o gambá era o mais significativo, infectaram os bovinos locais. Surtos inesperados de infecções no gado foram associados à uma única cepa de M.bovis, ainda que mais que uma cepa estivesse presente na população selvagem local. Isto indicou que a infecção do gado nesta área em particular, foi devida a apenas um, ou a um pequeno número de gambás infectados ${ }^{70,73}$.

Esta técnica foi utilizada, também na Nova Zelândia, durante outros surtos de tuberculose bovina, demonstrando ser de considerável importância epidemiológica para a tipificação de M.bovis no bovino e outras espécies animais, presentes nas áreas epidêmicas ${ }^{72,252}$. A técnica foi altamente discriminatória e identificou 95 tipos diferentes de restrição entre os 530 isolamentos de M.bovis ${ }^{72}$. A REA poderia revolucionar estudos epidemiológicos sobre o M.bovis e outras micobactérias ${ }^{125,199}$. 
Em 1989, de um total de 163 amostras, provenientes de 9 texugos, 6 cervos e 148 bovinos tuberculosos na República da Irlanda, foram isoladas 150 cepas de M.bovis, consideradas semelhantes em suas propriedades bioquímicas e culturais $86,126,216$.

No período de novembro de 1989 a maio de 1990, a REA foi usada para tipificar 20 isolamentos de M.bovis recuperados de 8 texugos e 12 bovinos de 9 rebanhos atingidos, em 4 municípios da República da Irlanda (Cork, Cavan, Offaly, Limerick), usando as 3 endonucleases citadas acima ${ }^{72,216}$. Um total de 12 tipos de restrição de M.bovis foram identificadas, sendo 10 cepas diferentes entre os 12 isolamentos de bovinos, e 8 cepas diferentes entre os 8 texugos. Entretanto em 6 casos, as cepas dos texugos pertenciam à mesma espécie de restrição obtida de um dos bovinos infectados na mesma área. Como os texugos estavam em íntimo contato com o gado, eles podem ter sido responsáveis por 6 , dos 9 surtos investigados ${ }^{72}$.

Um estudo realizado em 1993 na Austrália, comparando as técnicas RFLP e REA, demonstrou que a tipagem pelo RFLP identificou 27 cepas diferentes de um total de 36 isolamentos de M.bovis, e 7 cepas referentes ao complexo M.tuberculosis ( 3 cepas de M.africanum e uma cepa de cada uma da espécies: M.bovis AN5, M.bovis BCG, M.tuberculosis H37Rv e M.microti). As 36 cepas de M.bovis foram isoladas de 11 humanos, 17 bovinos, 5 suínos selvagens, 1 búfalo, 1 gambá e 1 foca ${ }^{216}$.

Utilizando a REA, 24 cepas foram identificadas usando as endonucleases de restrição BclI e PvuII e 23 cepas usando a BstEII. Somente quando os resultados das 3 enzimas de digestão foram combinados, a REA identificou as 27 cepas de M.bovis ${ }^{86}$.

Este estudo demonstrou que o RFLP, usando apenas o pTBN12 (seqüência repetitiva de DNA, clonada de M.tuberculosis), foi capaz de identificar diferenças no DNA, tão bem quanto a REA, usando 3 enzimas ${ }^{86}$.

Essa técnica não tem obtido uma grande aceitação, principalmente por causa da necessidade de se usar 3 enzimas de digestão para cada cepa, e pelas dificuldades na interpretação dos fragmentos de DNA obtidos, que são muito complexos, devido 
ao grande número de bandas produzidas ${ }^{86,252}$.

\section{f) PCR (Reação em cadeia da polimerase)}

Introduzida em 1986 por Mullis e Faloona, a polymerase chain reaction (PCR) é uma técnica revolucionária, que permite a amplificação in vitro de um trecho de DNA, milhões de vezes em poucas horas ${ }^{6,27,50,73}$. Quando combinada com uma prova de DNA, tem sido possível a identificação de baixos níveis de DNA bacteriano (aproximadamente dois organismos) $27,50,73$. No PCR, reproduz-se o processo de replicação natural do DNA, com as vantagens de extrema rapidez e de ser possível determinar precisamente o trecho de DNA a ser amplificado, ao passo que, na replicação normal todo o genoma é amplificado, e lentamente. O PCR tem acelerado consideravelmente toda a pesquisa em Biologia Molecular ${ }^{6,50}$.

No PCR, o DNA é sucessivamente duplicado, de uma maneira semelhante à que ocorre naturalmente dentro das células. Assim, o PCR deve satisfazer as condições básicas do processo de replicação do DNA realizadas pelas DNA polimerases, que agem exclusivamente sobre fitas despareadas de DNA. Ainda, para começar a duplicação, a DNA polimerase necessita que a fita a ser duplicada já tenha alguns nucleotídeos complementares pareados ao seu início. No PCR, a separação das fitas é obtida por desnaturação térmica do DNA. Termocicladores computadorizados (aparelhos de aquecimento programado) permitem variações térmicas cíclicas precisas e rápidas. Oligonucleotídeos complementares às extremidades do trecho de DNA que se quer amplificar garantem o pareamento inicial necessário, para que a polimerase inicie a replicação. Esses oligonucleotídeos são denominados primers ${ }^{6,192}$.

Um dos elementos que viabilizaram o PCR foi a descoberta de uma espécie de bactéria, Thermus aquaticus, que vive em altas temperaturas. A DNA polimerase extraída dessas bactérias (Taq polimerase) é capaz de resistir ao agressivo ciclo térmico do PCR. Outro ponto importante foi o desenvolvimento de termocicladores, progressivamente aperfeiçoados em termos de precisão, rapidez e custo ${ }^{6}$. 
Um elemento chave no PCR são os primers. Só haverá amplificação do DNA se houver hibridização do primer com um trecho do DNA da amostra. Este quesito confere especificidade à reação, pois, entre as inúmeras sequiências de DNA de uma amostra, somente será amplificada aquela que estiver contida entre trechos complementares aos primers utilizados. Assim os primers desempenham o papel de uma sonda, selecionando especificamente um determinado trecho de DNA, compreendido entre os dois primers, para amplificação. Primers podem também ser projetados e sintetizados sob medida, para amplificação de qualquer fragmento de DNA ${ }^{6,192}$. A detecção do DNA amplificado pode ser feita por gel de eletroforese corado com brometo de etídio ou por hibridização com sonda genética ${ }^{6,50,192}$.

A aplicabilidade desta metodologia no diagnóstico das doenças infecciosas tem sido intensamente pesquisada e as perspectivas são muito boas. Há evidências de uma sensibilidade de detecção de apenas uma bactéria em material clínico, ou mesmo fragmentos de DNA parcialmente degradados de organismos lisados $27,50,192$. No entanto, ainda persistem várias dificuldades para que ela seja utilizada em laboratórios clínicos, tais como a necessidade de condições muito rigorosas para evitar a contaminação do material em teste por fontes exógenas de DNA, com salas exclusivas para PCR, separação de pipetas, uso de reagentes aliquotados, etc; a eliminação da ação de inibidores de amplificação de DNA; a necessidade de melhoras na sensibilidade e especificidade do teste e de profissionais capacitados para a sua execução, além do alto custo ${ }^{50,192}$.

Além das dificuldades intrínsecas do método, a sua aplicação em micobacteriologia possui problemas adicionais como a lise da parede micobacteriana e também, técnicas de extração de DNA das micobactérias, que ainda são ineficientes 138, 192 . Alternativas ao PCR têm sido utilizadas, tais como a NASBA (Nucleic Acid Sustained Amplification) também conhecida como SSSR (Self Sustained Sequence Replication), a LCR (Ligasa Chain Reaction) e o fago $\mathrm{Q}_{\mathrm{B}}{ }^{50}$.

Apesar das dificuldades, tem sido descrita a amplificação de DNA do Complexo M.tuberculosis, com detecção de até 20 bacilos a partir de espécimes como derrame pleural, lavado brônquico e biópsias ${ }^{192}$. 
Barry e col. (1993) ${ }^{27}$ têm desenvolvido uma prova de DNA combinada com PCR para a região do espaçamento entre os genes RNA 16S e 23S ribossomais, que são específicos para o complexo M.tuberculosis, com a finalidade de detectar DNA de M.bovis no sangue de bovinos infectados. Em 10 amostras de sangue de gado tuberculina-positivo em Dublin, Irlanda, 9 foram positivas neste teste em um período de 24 horas, indicando que essa prova foi capaz de detectar o DNA do M.bovis no sangue de gado infectado, mas que extensas séries de experimentos deveriam ser realizadas para determinar o real valor deste teste, em termos práticos ${ }^{27}$.

Numerosos testes de PCR têm sido desenvolvidos para a detecção de micobactérias, mas poucos estudos têm analisado extensivamente amostras de tecidos, especialmente aqueles de uma variedade de animais ${ }^{277}$.

Em um estudo realizado na Nova Zelândia em 1993, Wards e col. (1995) ${ }^{277}$ desenvolveram um teste de PCR, para a detecção de pequenas quantidades de bacilos de M.bovis em tecidos de bovinos e outros animais tuberculosos. O método foi aplicado em 110 amostras de tecidos (106 linfonodos, 3 pulmões e 1 fígado) obtidas post mortem de bovinos, cervos, suínos, furões, gambás e carneiros. Das 58 amostras diagnosticadas como positivas na baciloscopia e cultura, 53 foram positivas no teste de PCR e das 52 amostras negativas na cultura, 5 foram positivas pelo PCR, incluindo 3 que eram baciloscopia positiva. Este teste foi capaz de detectar 10 organismos de culturas puras e entre 200-500 bacilos de tecidos, nos quais haviam sido injetados organismos cultivados ${ }^{277}$.

As 3 amostras baciloscopia positiva, mas cultura negativa, não estavam em boas condições quando chegaram ao laboratório, e o PCR indicou que o M.bovis estava presente, mas provavelmente não viável; o mesmo acontecendo com as outras 2 amostras baciloscopia e cultura negativas ${ }^{277}$.

A rapidez e a detecção de bacilos não viáveis foram algumas das vantagens dessa técnica. Entretanto, o fato das micobactérias serem organismos difíceis para a extração do DNA e, freqüentemente, patógenos intracelulares, sua purificação de amostras clínicas e particularmente tecidos é um obstáculo para este método. Componentes dos tecidos como a hemoglobina, podem inibir a reação de 
amplificação, por isso, a eficiência na preparação da amostra é decisiva no desenvolvimento de um PCR micobacteriano ${ }^{277}$.

Este estudo demonstrou que a detecção do M.bovis pela hibridização, foi marginalmente mais sensível que a cultura ${ }^{277}$.

Resultados semelhantes foram obtidos na Espanha, em 1994, quando foram testados pelo PCR os tecidos de 100 bovinos, dos quais 81 eram de rebanhos infectados, e os resultados comparados com a cultura. O PCR detectou apenas 71,4\% dos animais cultura-positivos, e todos os animais cultura-negativos ${ }^{176}$.

Em princípio, a técnica do PCR poderia ser utilizada para detectar DNA do M.bovis no escarro, sangue, swab nasal e outros tecidos. Infelizmente os primeiros PCR disponíveis, não discriminaram $M$. tuberculosis de M.bovis, e a sensibilidade e especificidade necessitaram de maiores avaliações ${ }^{117,295,296 .}$

Uma nova técnica de amplificação do PCR, denominada "Spoligotyping" (spacer oligonucleotide typing) e descrita por Kamerbeek e col., tem sido considerada a mais apropriada para a tipagem e identificação de cepas de M.bovis, distinguindo-as das cepas de M.tuberculosis e possibilitando a análise diretamente no material patológico, em apenas 2 dias. O método detecta a presença ou ausência de espaçamentos de uma seqüência conhecida do genoma do M.bovis ${ }^{17,36}$.

Esta técnica foi utilizada, com sucesso, em um hospital de Madri, Espanha, para elucidar um surto de tuberculose por cepas de M.bovis multidroga-resistentes entre pacientes aidéticos, no período de dezembro de 1993 a fevereiro de $1995^{36}$.

Foi utilizada também para estudar a epidemiologia das tuberculoses bovina e caprina, anteriormente analisadas pelo RFLP, além de isolar 182 cepas de M.bovis de outros animais domésticos e selvagens, na Espanha. Entre as 182 cepas de M.bovis investigadas, foram identificados 24 spoligotypes diferentes. Em todas as cepas testadas, faltaram os espaçamentos 39 a 43, uma característica particular, que distingue M.bovis de M.tuberculosis ${ }^{17}$.

Este estudo demonstrou que as cepas de M.bovis encontradas nos animais 
selvagens (cervos e suínos) da Espanha, foram também encontradas nos bovinos da região, sugerindo a transmissão da infecção entre esses animais e bovinos, possivelmente por utilização do mesmo pasto ${ }^{17}$.

As cepas isoladas de cabras e carneiros eram semelhantes entre si, mas diferiam das encontradas nos bovinos devido, possivelmente, a uma prática comum em algumas regiões da Espanha, que consiste em fazendas de criação exclusivas de rebanhos de cabras e carneiros ${ }^{17}$.

A cepa de M.bovis isolada de um gato, também foi semelhante à dos bovinos, sugerindo uma transmissão pelo contato direto com o gado no pasto ou no estábulo, ou por ingestão de sobras alimentares contaminadas ${ }^{17}$.

A principal vantagem do spoligotyping sobre o RFLP é sua simplicidade e rapidez, e o requerimento de somente uma pequena quantidade de DNA. Esta técnica é particularmente útil para o estudo da tuberculose por M.bovis, principalmente nos animais cujas cepas contenham uma única seqüência de inserção IS6110 ${ }^{17}$.

Apesar de todos estes estudos, ainda é aconselhável confiar em técnicas já estabelecidas, porque as técnicas modernas, em particular o PCR, necessitam de mais avaliações no sentido de evitar resultados falso-negativos e falso-positivos e validar seu desempenho sob as condições dos países nos quais os testes serão usados, principalmente os tropicais $295,296$.

A principal desvantagem desses novos métodos é que eles não têm sido suficientemente sensíveis para detectar as micobactérias diretamente nas amostras clínicas, particularmente em tecidos. Portanto, enquanto não forem desenvolvidos métodos melhores para a extração do DNA, de pequenas quantidades de bacilos nos tecidos, o exame bacteriológico com a realização da baciloscopia e cultura, ainda é o padrão ouro para o isolamento do M.bovis e para a avaliação de qualquer teste diagnóstico ${ }^{73,78,191,277 .}$

\section{5- TRANSMISSÃO}




\subsection{1- BOVINO PARA BOVINO}

A transmissão da infecção de um bovino para outro, pode ocorrer pela inalação ou ingestão de material infectado $42,48,148,201,237,261$. O bovino elimina o bacilo da tuberculose no leite, no ar expirado, no corrimento nasal, nas fezes, urina, nas secreções vaginais e uterinas, e pelo sêmen ${ }^{48,240,241,281,282}$.

A inalação (via aerógena) é a rota mais comum de infecção no gado, e 80 a 90\% das infecções podem ser contraídas por essa via de transmissão 2, 127, 180, 199, 201, $214,237,281,285$. Por isso, a tuberculose no gado é principalmente uma doença pulmonar, e apesar de apenas $1 \%$ das vacas tuberculosas excretarem bacilo tuberculoso em seu leite, elas provavelmente transmitem a doença pela via aerógena $^{127}$.

Uma minoria das infecções pode ser congênita, pela amamentação ou sexualmente transmitida. Quando a transmissão ocorre por ingestão, o que é mais comum em bezerros, a fonte de infecção é usualmente leite infectado, alimento, forragem ou água contaminada 2, 180, 199, 201, 208, 237, 241, 261, 281 . As águas residuais não depuradas, procedentes especialmente de indústrias leiteiras e matadouros, podem contaminar também os pastos e produzir o contágio, por via digestiva ${ }^{281}$.

Uma pequena porcentagem de bezerros podem se infectar antes de nascer quando as vacas são vítimas de uma tuberculose uterina, apesar de ser muito raro que essas vacas doentes continuem prenhes. As formas raras da tuberculose testicular, vaginal e vulvar podem ser transmitidas no ato da cópula ${ }^{237,281}$.

A transmissão do M.bovis entre bovinos depende de numerosos fatores, dentre os quais se destacam a freqüência da excreção do bacilo, a rota da infecção, a dose infectiva, o período de comunicabilidade, a susceptibilidade do hospedeiro, a densidade da população animal, manejo e instalações adequadas e principalmente a estabulação, que propicia o contato estreito e freqüente entre os animais 54, 201, 216. Estudos experimentais em laboratórios animais têm indicado que o tamanho das partículas contendo a micobactéria é de importância crítica na determinação da infectividade ${ }^{216}$. 
Existem questões ainda não respondidas, a respeito do reconhecimento de que bovinos infectados, mas não detectáveis pelo teste tuberculínico, possuem respostas imunes demonstráveis in vitro, e de que é possível isolar o M.bovis de secreções respiratórias e linfonodos pulmonares nesses animais, mesmo na ausência de um foco primário detectável $^{208}$.

Por esse motivo, devido à importância da transmissão aerógena, muitos fazendeiros e veterinários envolvidos no controle da tuberculose bovina consideram, erroneamente, como animais perigosos e excretores de bacilos, somente aqueles com lesões pulmonares claramente identificáveis (animais VL). No entanto, os animais nos estágios iniciais da doença, anteriores ao desenvolvimento de lesões detectáveis (animais NVL) contribuem substancialmente na produção de aerossóis infecciosos. Portanto, o animal, uma vez infectado, já é capaz de transmitir a doença a outros, mesmo antes do desenvolvimento de lesões teciduais, ou seja, os bovinos são capazes de transmitir a infecção em qualquer estágio da doença 130, 143, 144, 145, 196, 199, 208, 241.

A tuberculose no gado é uma doença lenta, crônica e insidiosa. Por isso, as perdas que ocasiona não são geralmente tão ostensivas, e se manifestam em uma diminuição progressiva da capacidade produtiva dos animais, que perturbam sensivelmente a economia das explorações pecuárias, que se ressentem pelo sacrifício dos animais afetados e, em algumas ocasiões, até dos suspeitos. Estas consequiências adversas da tuberculose, que aumentam os custos da produção e provocam a redução da oferta de proteínas de origem animal, na forma de carne e leite à população, são ainda maiores nas condições atuais de sistemas de criação intensiva, que facilitam o contato íntimo com os animais afetados ou com suas secreções e excreções contaminadas, e favorecem a propagação da doença $^{54,201,216,273,281}$.

O confinamento tem particular importância na difusão da doença no rebanho, o que explica a maior prevalência no gado leiteiro na medida em que a idade do rebanho aumenta, e a menor prevalência no gado de corte, os quais são abatidos precocemente sendo, portanto, menor o tempo de exposição aos membros infectados do rebanho $92,155,199,237,239,281,282$. O tamanho do rebanho também é importante na 
transmissão da infecção ${ }^{54,216}$. A tuberculose em um rebanho é introduzida, principalmente, pela aquisição de animais infectados, podendo se propagar nos bovinos independentemente da idade, sexo e raça ${ }^{54,201}$.

Na década de 50, experimento realizado na Grã-Bretanha demonstrou que quando os rebanhos consistiam de em média 17,2, 27,7 e 52,8 animais, a porcentagem de reatores ao teste tuberculínico foram respectivamente 4,3, 10,3 e $20,0 \%{ }^{216}$. Uma análise posterior da inspeção de carne e testes tuberculínicos mostrou que, em média, a incidência de tuberculose em bovinos aumentava uniformemente em cerca de 7,5\% para cada ano de vida, atingindo $40 \%$ aos 5-6 anos de idade; por isso, bezerros criados com vacas leiteiras estavam expostos a um constante risco de infecção pelas vias aerógena e digestiva, e quando não, aproximadamente $90 \%$ deles atingiam a maturidade ( 2 anos) sem serem infectados ${ }^{216}$.

Investigações epidemiológicas na Irlanda mostraram que acima de $15 \%$ da recém introduzida infecção pelo M.bovis em rebanhos de gado, foi devida à compra de gado infectado e que a propagação lateral da infecção por M.bovis entre rebanhos bovinos próximos foi a principal fonte de contágio ${ }^{144,149,216 .}$

Correa e col. $(1980)^{82}$ descreveram o primeiro caso de tuberculose nervosa em uma vaca leiteira, no Brasil. É um tipo raro de tuberculose em bovinos e outros animais domésticos e constitui, aproximadamente, apenas 0,04\% das localizações da tuberculose. Este caso ocorreu em 1978 em Minas Gerais, em uma vaca leiteira que apresentava sintomatologia nervosa e cuja necropsia revelou tuberculose miliar generalizada e com tubérculos encefálicos. Os autores concluíram que a doença atingiu o sistema nervoso central (SNC) por via hematogênica ${ }^{82}$.

Roxo e col. (1990) ${ }^{238}$ relataram um caso de tuberculose generalizada em um bezerro da raça holandesa em Presidente Prudente, São Paulo, proveniente de um rebanho comprovadamente tuberculoso. Por volta do $20^{\circ}$ dia de vida, o animal começou a apresentar sintomatologia respiratória, tratada inicialmente como pneumonia, porém sem manifestar melhora significativa. Em 1 mês, os sintomas agravaram-se e com, aproximadamente, 3 meses de idade veio a óbito, revelando à necropsia extensas lesões nodulares caseosas no pulmão, linfonodos e intestinos. $\mathrm{O}$ 
cultivo de fragmentos de pulmão proporcionou o isolamento de M.bovis. Como a observação de tuberculose em bezerros, com sintomatologia clínica é considerada rara, os autores sugeriram que pode ter ocorrido transmissão transplacentária ou por via respiratória, através do contato direto com a mãe ou outros animais doentes, ou ainda pelo consumo de colostro e/ou leite contaminado ${ }^{238}$.

Poucos são os relatos de tuberculose genital em bovinos, tanto na literatura nacional, como internacional ${ }^{29,250}$. A tuberculose genital ocorre como conseqüência de coito, por sêmen contaminado, por peritonite tuberculosa e principalmente por via hematogênica ${ }^{29}$. Silva e col. (1980) ${ }^{250}$ descreveram um caso de tuberculose genital em touro. Um reprodutor bovino, de 6 anos de idade, da raça holandesa malhada de vermelho, de origem canadense, apresentava bom estado clínico, mas a inspeção do trato genital, revelou expressivo aumento de volume da parte lateral direita da bolsa escrotal. Baseando-se na reação positiva à tuberculinização, procedeu-se ao sacrifício do animal, que no exame post mortem apresentou lesões tuberculosas nos pulmões, gânglios mediastínicos e aparelho genital envolvendo os testículos, tubos seminíferos, epidídimo e cordão espermático ${ }^{250}$.

Basile e col. (1985) ${ }^{29}$, relataram um caso de tuberculose genital em uma vaca Nelore, de 3,5 anos de idade, adquirida como gestante de 45 dias, em uma Exposição Agropecuária, e levada à uma propriedade no Paraná. Na época do parto constatouse, por palpação retal, um útero volumoso, de consistência dura e parede espessa. $\mathrm{Na}$ necropsia, verificou-se que o conteúdo uterino era um nódulo caseoso, com focos de calcificação e no exame bacteriológico, encontraram-se bacilos álcool-ácido resistentes, identificados posteriormente como M.bovis. Os autores alertaram às autoridades competentes e aos profissionais da área, sobre a exigência dos exames sanitários obrigatórios por lei, para o acesso de animais em recintos de Exposições e Feiras Agropecuárias ${ }^{29}$.

Roxo e col. (1993) ${ }^{239}$ relataram que em um lote de 18 novilhas sem raça definida, adquiridas a fim de servirem como receptoras para transferência de embrião em um rebanho Nelore foram identificados 14 animais tuberculina-positivos. Após o sacrifício foram observadas lesões generalizadas em 4 animais. A cultura de 
fragmentos de útero, pulmão e linfonodos, levou ao isolamento de M.bovis. Os autores salientaram a gravidade das lesões observadas, tendo sido encontradas, inclusive, no aparelho reprodutivo (útero e ovário) e como a tuberculose genital é considerada de baixa ocorrência em bovinos, alertaram para o cuidado sanitário na aquisição de animais ${ }^{239}$.

Não há registros de casos de transmissão bovino-para-bovino do M.tuberculosis, o bacilo da tuberculose humana ${ }^{216}$.

\subsection{2- BOVINO PARA HUMANO}

A tuberculose bovina é uma das zoonoses mais importantes. Aproximadamente $10 \%$ de sua incidência na espécie humana, se deve a bacilos procedentes de bovinos. O M.bovis é tão patogênico para o homem quanto o M.tuberculosis 236, 237, 281 .

A tuberculose pulmonar devida ao M.bovis é transmissível do gado para humanos diretamente pela via aerógena, mediante a inalação do M.bovis e indiretamente, pelo consumo de leite e produtos lácteos não fervidos ou pasteurizados 42, 48, 57, 91, 93, 104, 127, 148, 160, 175, 196, 201, 217, 228, 237, 259, 295, 296 . A carne bovina, a rigor, não pode ser apontada como fonte de infecção para a tuberculose humana, pelo menos nos países onde é submetida à cocção, porque é raro o encontro do bacilo na musculatura. Por prudência, entretanto, a inspeção sanitária faz a condenação parcial ou total das carcaças, conforme o caso ${ }^{204}$.

A infecção pelo M.bovis era o principal problema de saúde pública quando os bacilos eram transmitidos ao homem pelo leite de vacas infectadas $127,216,236$. A tuberculose bovina era considerada uma doença de crianças, que envolvia linfonodos cervicais, o trato intestinal ou as meninges, resultando em formas extrapulmonares. Por isso, as formas de tuberculose mais frequientes, eram a ganglionar, ósteo-articular e meningite. A entidade clínica caracterizada pelo inchaço e alastramento dos linfonodos tuberculosos no pescoço, era denominada escrófula ${ }^{127,160,196,201,216,236,282}$. 
Como já foi dito anteriormente, o bovino elimina o bacilo da tuberculose no leite, no ar expirado, no corrimento nasal, nas fezes, urina, nas secreções vaginais e uterinas, e pelo sêmen ${ }^{48,240,241,281,282}$. A aquisição da infecção devida ao M.bovis, por meio da inalação de aerossóis contendo o bacilo, proveniente de reses infectadas ou mortas (manuseio das carcaças), ocorre com menor freqüência 42, 92, 148, 163 , entretanto sua incidência não é desprezível, sobretudo em grupos ocupacionais de maior exposição à doença, como tratadores de rebanhos, ordenhadores e seus familiares, trabalhadores da indústria de carne (açougueiros, pessoal de matadouros e frigoríficos) e veterinários, além de membros da comunidade rural, que vivem em íntimo contato com seus animais 4, 48, 57, 74, 92, 129, 142, 148, 160, 163, 196, 201, 228, 237, 259.

Uma rota de infecção menos comum pelo M.bovis é a via cutânea, por contato direto com material contaminado, através de feridas e abrasões na pele, principalmente em açougueiros, trabalhadores de matadouros, veterinários e patologistas que manuseiam carnes e animais tuberculosos, muitas vezes resultando em verrugas nas mãos e braços desses profissionais ${ }^{110,127,228}$.

Geralmente, o contato entre animais e homens, ocorre em condições ambientais desfavoráveis, tais como, umidade excessiva, estábulos sem insolação e sem ventilação, acúmulo de fezes e moscas, ou seja, sem condições higiênicas adequadas $^{116}$.

A exploração leiteira é o setor rural de maior risco para o homem, devido ao estreito contato do ordenhador e seus familiares com os animais, em repetidas ocasiões durante todos os dias de trabalho, e ao fato de que as vacas leiteiras apresentam uma maior susceptibilidade à tuberculose bovina. As principais causas dessa susceptibilidade maior são o stress e a manutenção de animais de maior idade para a produção láctea. Este fato não ocorre no gado de corte, que se mantém por menos tempo em criações extensivas, sendo menor o contato entre animais e homens $^{74}$. Uma vaca tuberculosa pode excretar um número gigantesco de bacilos. Uma só vaca pode excretar bacilos viáveis suficientes para contaminar todo o leite misturado, proveniente de 100 vacas ${ }^{160}$. A aerolização do M.bovis no momento da ordenha, pode causar conjuntivite e infecções orais nos ordenhadores ${ }^{228}$. 
A usual fonte de M.bovis no leite é a infecção do úbere da vaca, mas também pode ocorrer pela contaminação com fezes, secreções de abcessos uterinos e pelo ar ou poeira com bacilos ${ }^{196,228,281}$. Diferenças culturais na preparação e uso do leite afetam profundamente a transmissão da tuberculose bovina. Em muitas culturas, apesar do leite para o consumo ser usualmente fervido, manteigas e cremes de leite são produzidos com leites não fervidos, tornando-se uma fonte de M.bovis. No mundo todo, a prática de se beber leite cru está associada com o hábito e o modo de vida da população rural e aumenta o risco de infecção, principalmente em crianças ${ }^{228}$.

A tuberculose pode ser transmitida ainda pelo contato com alimentos, produtos de carne, ou água, contaminados com o bacilo 102, 196, 237 . A detecção da tuberculose humana por M.bovis reveste-se de importância, pois revela focos de infecção nos países onde o bacilo bovino não tem sido encontrado ${ }^{4}$.

A proporção de casos de tuberculose humana causada por M.bovis apresenta uma considerável variação regional, dependendo da presença e extensão da doença na população bovina local, da situação social e econômica da região, dos padrões de higiene alimentar e da aplicação de medidas preventivas ${ }^{196}$.

Em 1928, na Europa, era freqüente que o primeiro contato de crianças com o antígeno bacilar ocorresse através do bacilo bovino contido no leite (via oral), o que originava altas cifras de tuberculoses primárias, extrapulmonares ou generalizadas ${ }^{154}$. Dos 877 casos de tuberculose em menores de 16 anos de idade, ocorridos na época, $787(89,7 \%)$ eram infecções extrapulmonares ou generalizadas, e em $24,5 \%$ delas, o agente causal era o bacilo bovino. Na tuberculose pulmonar, por via aerógena, apenas $2 \%$ dos casos eram de origem bovina ${ }^{154,272}$.

É interessante observar que a primeira pasteurização compulsória do leite, foi introduzida em 1898 não para proteger a saúde humana, mas para prevenir que porcos e bezerros fossem infectados pelo M.bovis, com o leite proveniente de leiterias da Dinamarca ${ }^{216,228 .}$

O Reino Unido foi o mais resistente entre muitos países, em admitir o problema do leite como uma fonte de infecção de M.bovis, ocorrendo durante a 
década de 30, cerca de 2.500 mortes e pelo menos 4.000 novos casos de tuberculose humana por este agente, a cada ano ${ }^{154,216}$. Em 1945, as cepas bovinas eram responsáveis por $5 \%$ de todos os casos fatais de tuberculose, e 30\% dos casos em crianças menores que 5 anos de idade ${ }^{68}$.

Além do hábito da população de consumir leite cru, foi realizado um estudo em 24 municípios da Suécia em 1935, no qual se encontrou que o nível de risco da infecção por M.bovis no homem, estava relacionado com a prevalência da infecção tuberculosa nos rebanhos bovinos, variando desde 3,4\% em municípios com menos de $2 \%$ de gado infectado, até $5,8 \%$ em condados com $20 \%$ ou mais de bovinos infectados 251 .

Em 1936, ocorreu um surto de tuberculose bovina transmitida pelo leite, em escolares residentes em uma pequena vila na Suécia, cujo leite provinha de um rebanho de 22 vacas. Uma dessas vacas tinha mastite tuberculosa e um grande número de bacilos estava presente no leite. Dos 32 escolares que beberam o leite, 29 eram positivos ao teste tuberculínico, e entre 18 pré-escolares que beberam o leite, 16 estavam positivos ${ }^{216}$.

Na Suécia, em 1938, Törnell relatou que no distrito dispensarial de Alvsborgs Län, 4 surtos epidêmicos de tuberculose por M.bovis haviam sido observados, desde 1935. O primeiro referia-se a 13 crianças em férias, procedentes de Göteborg. Não reagiram a princípio à tuberculina, mas durante sua permanência na casa de férias, adoeceram com manifestações de primo-infecção, algumas com eritema nodoso, outras com sintomas abdominais, tornando-se sensíveis à tuberculina. Não tendo sido encontrado o foco de contágio entre as pessoas em contato com as crianças, recomendou-se ao proprietário da casa o exame das vacas que possuía, tendo o veterinário verificado que uma delas sofria de mastite tuberculosa. Além disto, verificou-se a presença do bacilo de Koch no leite do animal ${ }^{110}$.

O segundo surto acometeu 13 operárias em uma fábrica, nas proximidades de Boros, e não se encontrando um foco de contágio humano comum, porque as moças trabalhavam em seções afastadas uma das outras, verificou-se que o leite que lhes era fornecido pela fábrica estava contaminado pelo bacilo de Koch. No terceiro surto 
epidêmico, ocorrido em Horrend, 50 pessoas foram infectadas, crianças em sua maioria, e pôde se identificar o foco de contágio, que também era uma vaca sofrendo de mastite tuberculosa ${ }^{110}$.

Finalmente, o quarto surto iniciou-se pelo adoecimento de um jovem que desenvolveu um processo tuberculoso nas amígdalas e que meses depois apresentou tuberculose pulmonar. Uma investigação entre os seus comunicantes não conseguiu identificar a origem do contágio, mas apurou que, o rapaz bebia leite sempre da mesma leiteria. Baseado neste fato realizou-se um inquérito entre os tuberculosos residentes nas proximidades da leiteria, comprovando-se que aqueles que a tinham freqüentado adoeceram, mais ou menos ao mesmo tempo ${ }^{110}$.

Em Ontario, no Canadá, a primeira lei requerendo a pasteurização do leite comercializado, foi um estatuto municipal adotado pela cidade de Toronto em 1915. Outros municípios foram lentos para aprovar estatutos similares e, por essa razão, em 1938, apenas $30 \%$ dos municípios que possuíam uma população superior a 2.000 habitantes, pasteurizavam o leite ${ }^{283}$.

Em 1932, o bacilo bovino era o agente infeccioso de 14,1\% dos casos de tuberculose em crianças canadenses. Em todos os casos, havia o antecedente de ingestão de leite cru ${ }^{154,272}$. Em 1964, em Ontario, um rebanho de 59 bovinos de corte e de leite apresentou 16 animais tuberculosos. Uma família inteira havia bebido leite cru desse rebanho e ao serem examinados pelo serviço de saúde local, um garoto de 8 anos havia desenvolvido adenite cervical, e outros 4 membros da família apresentaram viragem tuberculínica ao serem testados. Apesar da transmissão do M.bovis do bovino para o homem ter sido cosiderada uma rara ocorrência em Ontario em 1976, esse episódio ilustrou a necessidade da contínua vigilância animal ${ }^{283}$.

Antes da pasteurização do leite e abate do gado infectado, o M.bovis era responsável por 6-30\% dos casos de tuberculose humana nos Estados Unidos ${ }^{108}$.

Em junho de 1963, em Connecticut, um farmacêutico de 55 anos foi hospitalizado com febre e dor torácica. Após uma biópsia, suspeitou-se de tuberculose miliar e foi iniciada a quimioterapia. $\mathrm{O}$ paciente não apresentou melhoras 
e somente 11 meses após o início do tratamento o M.bovis foi isolado. Em agosto de 1964, no $14^{\circ}$ mês de tratamento, o paciente faleceu, e sua morte foi atribuída a uma progressiva micobacteriose. Esse paciente apresentou diferentes graus de resistência a algumas drogas antituberculosas, no início do tratamento, e desenvolveu resistência a outras drogas durante o tratamento. Aparentemente, ele contraiu a infecção na juventude, por meio de leite infectado, em uma época que havia uma grande incidência de tuberculose nas vacas e a pasteurização do leite não era uniforme ${ }^{141}$.

Em 1967, na Georgia, um homem de 57 anos de idade que apresentava uma infecção tuberculosa, foi hospitalizado por 5 meses. Após a realização de diversas provas diagnósticas, estabeleceu-se que o bacilo envolvido era o M.bovis. Aparentemente, o paciente contraiu a infecção enquanto trabalhava como esfolador de pele bovina e escaldador em uma fábrica de subprodutos animais, mas este fato não pôde ser comprovado. O paciente morreu por complicações respiratórias, após 10 meses da alta hospitalar ${ }^{102,179}$.

A primeira pasteurização do leite na Eslováquia foi em Bratislava em 1952. Na República Eslovaca, existia em 1995 uma média de 27.800 vacas por 100.000 habitantes, ou seja, mais que 3 pessoas para 1 vaca, o que facilitou a ocorrência de esporádicos casos de tuberculose humana causada pelo M.bovis ${ }^{19}$.

O papel do M.bovis na doença pulmonar e outras lesões, foi estabelecido por Griffith em 1937, na Grã-Bretanha. Ruys (1939) na Holanda e Sigurdsson em 1945 na Dinamarca forneceram evidências da transmissão da tuberculose do gado para o homem por inalação, nos estábulos, e da propagação do M.bovis de homem para homem pela via pulmonar ${ }^{228}$.

Sigurdson em 1945 publicou o resultado de um estudo sobre a relação entre tuberculose pulmonar no homem e tuberculose no bovino em um município da Dinamarca. Ele dividiu os 566 pacientes em 3 grupos: 165 rurais, 39 urbano-rurais e 362 urbanos. A porcentagem da infecção bovina nos 3 grupos foi 40,6\%, 28,2\% e $3,6 \%$, respectivamente. Todos os 165 pacientes rurais haviam tido contato com rebanhos de gado. Posteriormente, ele dividiu os rebanhos bovinos em 3 grupos também: infecciosos, tuberculina-positivos mas aparentemente saudáveis, e 
tuberculina-negativos; e os pacientes de acordo com o grupo de rebanhos com os quais eles haviam tido contato nos últimos 2 anos, antes da doença ser diagnosticada. Observou que dos 67 pacientes com tuberculose bovina, a grande maioria, ou seja, 63 pacientes $(94 \%)$ haviam tido contato com o gado tuberculina-positivo e com os bacilos que foram encontrados na poeira dos estábulos, demonstrando assim, a importância da infecção por inalação para pessoas que trabalhavam com gado tuberculoso ${ }^{110,266}$.

O declínio da importância da infecção pelo leite, após a obrigatoriedade da pasteurização, e a crescente importância da infecção por inalação do bacilo, também foram demonstradas em um estudo realizado por Christiansen em Jutland, na Dinamarca, durante o período de 1943 a 1952. Ao analisar todos os casos de tuberculose bovina no homem, diagnosticados nesse local, encontrou 60,8\% de casos pulmonares em adultos, nos primeiros 5 anos do período estudado e 72,6\%, nos últimos 5 anos. Em crianças abaixo de 15 anos de idade, a porcentagem de casos pulmonares foi de $11,8 \%$ e $1,1 \%$, respectivamente. Observou também, que mais de $90 \%$ dos pacientes adultos trabalhavam na agricultura e mais de $80 \%$ lidavam com o gado $^{266}$.

Muitos pesquisadores demonstraram que a tuberculose pulmonar devida ao M.bovis era mais comum entre os habitantes rurais do que entre os urbanos. Schmiedel, em 1968, por exemplo, demonstrou que na região leste da Alemanha, as porcentagens de tuberculose pulmonar causada por M.bovis entre aqueles que viviam no campo, em cidades pequenas ou médias, e em grandes cidades, foram 17,1\%, $1,4 \%$ e $0,2 \%$, respectivamente. Ele também notou que a pasteurização compulsória do leite teve pouco impacto na incidência da tuberculose pulmonar devida ao M.bovis na população rural, mas reduziu drasticamente a incidência de doença abdominal, devida a este bacilo, na população urbana ${ }^{127}$.

Informações de infecção pulmonar por M.bovis em trabalhadores de abatedouros na Austrália realçaram a via aérea da infecção como um risco ocupacional 91, 108, 179, 216. Um total de 87 casos de infecção por M.bovis (74 em homens e 13 em mulheres) foi registrado em Queensland, no período de 1953 a 1981. 
A faixa etária foi de 17 a 89 anos, com muitos casos (82\%) em idades superiores a 40 anos. A tuberculose pulmonar por M.bovis, ocorreu em 67 (77\%) dos pacientes. Dos 20 casos de doença extrapulmonar, 12 (60\%) tiveram tuberculose pulmonar coexistente ${ }^{108,216}$.

Desse total de 87 casos, $16(18,4 \% \%)$ pacientes não registraram exposição significante ao gado ou a casos conhecidos de tuberculose bovina, 13 (14,9\%\%) pacientes beberam leite não pasteurizado, $1(1,2 \% \%)$ paciente foi exposto a outro infectado por M.bovis, e em $57(65,5 \%)$ casos, houve exposição doméstica ou ocupacional ao gado, sendo que 40 pacientes eram açougueiros. Um grupo de 4 pacientes ( 1 homem, sua esposa, seu filho e um sobrinho) eram todos empregados na indústria da carne. A transmissão intra-domiciliar do M.bovis nesta família foi possível, mas não pode ser comprovada ${ }^{108,216}$.

Em outro relato, foram descritos 4 casos de tuberculose bovina ocorridos em um período de 2 anos, na década de 80, no sul da Austrália. Todos os 4 pacientes tiveram um histórico em abatedouros (embora 4 abatedouros distintos estivessem envolvidos) e apresentaram tuberculose pulmonar ou pleural ${ }^{108,216}$.

No sul da Austrália, em 1980, ocorreram 5 casos de infecção humana pelo $M$. bovis em trabalhadores de abatedouros, sendo que 4 pacientes tinham lesão pulmonar e um apresentava tuberculose renal. Em um dos pacientes havia evidências de transmissão intradomiciliar ${ }^{108}$.

Quanto ao risco de aquisição da infecção por M.bovis pela carne, vários trabalhos realizados no passado demonstraram que, enquanto cerca de 5 bacilos produziam infecção em bezerros ou carneiros pela via respiratória, muitos milhões de bacilos eram, freqüentemente, requeridos para infectá-los pela via intestinal. A posição é, provavelmente, similar no homem, exceto para crianças pequenas, e a maior importância da via respiratória para a infecção no homem e gado, é agora bem reconhecida ${ }^{118}$. A carne e as vísceras de animais tuberculosos não representam fonte importante de contágio, porque não somente são rejeitadas nos matadouros e frigoríficos, como também a cocção para o seu preparo, mata os bacilos que contêm ${ }^{110}$. Portanto, o número de pessoas que têm sido infectadas por meio do 
consumo de carne, proveniente de animais tuberculosos, deve ser relativamente muito pequeno ${ }^{74,118}$. A carne infectada representa um perigo maior quando é consumida crua ${ }^{74,196}$.

Em um estudo realizado por Blancou e Cheneau (1976) ${ }^{35}$ em Madagascar, na África, em 265 bovinos contaminados por M.bovis, em diferentes graus, demonstrou-se que o bacilo foi raramente encontrado nos músculos ou sangue desses animais, ocorrendo em apenas $3(1,1 \%)$ bovinos, com 2 isolamentos no músculo e 1 no sangue. O método de coleta utilizado pressupunha uma perfeita assepsia de todos os equipamentos, uma vez que o bacilo é capaz de contaminar locais, móveis, vestimentas e mãos dos inspetores, evitando-se assim uma possível contaminação das amostras colhidas. Segundo os autores, não havia dúvidas de que a falta dessas precauções produziriam numerosos resultados aberrantes, em pesquisas de bacilo de Koch, nas carnes de bovinos ${ }^{35,118}$.

Os autores deste estudo, concluíram que era muito baixo o risco de contaminação para o ser humano que consumisse a carne de bovinos tuberculosos ${ }^{35}$. Este posicionamento foi diferente para o leite, porque este, como o escarro, podia ser pesadamente infectado com o bacilo da tuberculose e porque, em ambos os casos de infecção, a glândula mamária e pulmões com lesões tuberculosas, descarregavam os bacilos diretamente no sistema canalicular ${ }^{118}$.

No período de novembro de 1992 a março de 1993, dos 2.226 bovinos submetidos ao teste da tuberculina em um distrito rural de Zâmbia, na África, denominado Monze, 165 (7.4\%) eram reatores positivos, indicando que 33\% dos rebanhos da região continham pelo menos 1 animal tuberculina-positivo. Dez pessoas apresentaram tuberculose por M.bovis, devido ao íntimo contato com os rebanhos de gado, que fornecem o leite e são usados como força de tração para o cultivo, mas apenas são abatidos para funerais ou outras cerimonias. Para a população dessa região, a posse do gado é um sinal de riqueza e um complexo sistema social de obrigação mútua é mantido, em parte, através da permuta de bovinos dentro e entre famílias e outros grupos da região ${ }^{75}$.

Qualquer estudo realizado na África a respeito da importância zoonótica do 
M.bovis, deve considerar em primeiro lugar a população pastoril, devido ao íntimo contato com o gado e ao hábito de consumirem leite cru ou azedo. Em segundo lugar os consumidores de leite não pasteurizado nas áreas urbanas e em terceiro, os inspetores de carne e açougueiros que são expostos, ocupacionalmente, à carcaças de bovinos doentes ${ }^{90}$.

Os pastoris são de particular interesse, por causa das oportunidades que existem para transmissão cruzada do bacilo da tuberculose entre as pessoas e seus bovinos. Nessas comunidades, o leite pode ser bebido fresco, imediatamente após ser extraído da vaca, sendo freqüentemente oferecido às crianças, ou alternativamente, e mais comumente, o leite pode ser coalhado e consumido após ser armazenado em containers por alguns dias. Muitas sociedades pastoris têm a tradição de comer certas partes cruas de animais recentemente abatidos, pois o coração e fígado bovinos são considerados particularmente nutritivos e uma fonte de força militar quando consumidos crus, e por isso são ingeridos pelos jovens guerreiros da tribo ${ }^{90}$.

Na Etiópia, a carne crua é considerada uma iguaria e é muito consumida pela população. Em tempos de seca, quando a produção de leite pelas vacas é insuficiente para suprir as necessidades de uma família, o sangue é extraído da veia jugular do animal e ingerido puro ou misturado com leite. O sangue fresco também é, habitualmente, oferecido às pessoas doentes e mulheres após o parto. A urina do gado é utilizada para muitas finalidades, incluindo a lavagem dos utensílios que recebem o leite das vacas e para misturar com o solo para produzir uma superfície dura para pisos e paredes. Este trabalho é realizado por mulheres. O íntimo contato com o gado pode conduzir à transmissão da infecção pela via respiratória, sendo o risco ainda maior em algumas comunidades da Tanzânia, que compartilham suas acomodações com o gado, durante a noite. Essa e outras práticas tradicionais oferecem uma ampla oportunidade para os pastoris ingerirem, inalarem, ou adquirirem por contato com a pele, o M.bovis dos bovinos, ou inversamente, transmitirem a infecção para o gado ${ }^{90}$.

Além dessas oportunidades para a transmissão respiratória, existem certas práticas culturais, freqüentemente associadas com a medicina tradicional, que podem 
transferir a infecção. Uma das práticas é o uso do fumo mascado para restaurar o apetite de um animal. O proprietário cospe um chumaço de tabaco bem mastigado na boca do animal afligido, e mantém a sua boca na dele, para assegurar que o "remédio" seja deglutido. Outra prática comum é uma inflação forçada do útero da vaca, onde o dono do animal sela sua boca na vulva e sopra fortemente, com o objetivo de estimular a produção de leite ${ }^{90}$.

Na Índia, o consumo de leite cru ou não fervido é relativamente raro, e sua prática é limitada às pessoas que criam bovinos. Em 1994, ocorreu o primeiro caso de tuberculose lingual primária causada pelo M.bovis, em um homem de 32 anos de idade, que durante 8 anos consumiu leite cru de sua vaca doméstica. Essa vaca morreu, após uma breve doença, 3 meses antes do paciente procurar um hospital com sintomas de tuberculose e apresentando uma úlcera na língua e um aumento do linfonodo submandibular direito ${ }^{221}$.

A tuberculose lingual geralmente está associada com tuberculose de orofaringe, pulmões, linfonodos e tuberculose miliar. O envolvimento primário da língua é muito raro, e pode surgir como uma úlcera, nódulos, fissuras, tuberculomas ou granulomas. Alguns fatores responsáveis pela rara ocorrência da tuberculose lingual são: o pH da cavidade oral; a regular limpeza da língua pela saliva, que previne a fixação do BAAR; a resistência dos músculos estriados e mucosa da língua ao BAAR e a relativa escassez de tecidos linfóides (pelos quais o bacilo da tuberculose tem grande afinidade) na parte anterior da língua ${ }^{221}$.

Atualmente nos países desenvolvidos, a incidência de tuberculose bovina em crianças é quase zero, devido à universal pasteurização do leite e seus produtos e à baixa prevalência da infecção no gado desses países ${ }^{68,216}$.

A tuberculose humana devida ao M.bovis, tem sido considerada uma raridade nos países desenvolvidos. Realmente, quando tais infecções ocorrem acredita-se que elas representem reativações de doenças antigas ou que foram adquiridas no exterior. Entretanto, estão aumentando as evidências de que essas crenças são perigosamente falsas ${ }^{68,216}$. 
Há escassa informação epidemiológica sobre o impacto da tuberculose bovina na saúde humana na América Latina, talvez porque o diagnóstico bacteriológico da tuberculose humana é geralmente limitado ao exame de escarro (baciloscopia), e sempre que culturas são realizadas, o meio de Lowenstein-Jensen contendo glicerol, no qual as cepas de M.bovis têm dificuldade para crescer, é o único disponível $^{156,216,235}$. Em países onde o leite é fervido rotineiramente, como os da América Latina, a incidência da infecção humana pelo M.bovis através do leite tem se mantido baixa. Contudo, doenças pulmonares e não pulmonares devidas ao M.bovis, continuam a ser um problema nas áreas onde a prevalência da infecção no gado é alta $^{216}$.

Na Argentina, onde a prevalência da tuberculose no gado é relativamente alta e existe a pasteurização do leite e seus produtos, combinados com um alto padrão de inspeção de carne, muitos dos pacientes infectados com M.bovis são trabalhadores rurais ou de matadouros ${ }^{216}$.

No Brasil, dados sobre a prevalência da tuberculose humana causada pelo M.bovis, são desconhecidos ${ }^{4,110}$.

Também não há registros de casos de transmissão bovino-para-humano do M.tuberculosis $^{216}$.

\subsection{3- BOVINO PARA RESERVATÓRIOS ANIMAIS}

A tuberculose causada por M.bovis foi e tem sido descrita em muitas espécies de animais domésticos e selvagens, mas a prevalência da doença geralmente é menor, quando comparada com a dos bovinos, e encontrada preferencialmente onde animais domésticos estão em íntimo contato com bovinos tuberculosos ${ }^{181}$.

Acredita-se que a infecção por M.bovis em cervos, pode originar-se por compartilharem o mesmo habitat, ou se misturarem com bovinos tuberculosos domésticos ou selvagens ${ }^{173}$. 
Em 1974, ocorreu infecção por M.bovis em 3 cervos selvagens da raça "axis" e em bovinos selvagens na ilha Havaiana de Molakai. Concluiu-se que os cervos, presumivelmente, contraíram a infecção de gado selvagem domesticado. O M.bovis foi confirmado em $2(1,1 \%)$ de 185 cabeças de gado abatidos durante 2 expedições de caça em Molakai, em 1972. Estimou-se que havia na época, 3.000 a 5.000 cervos, dessa raça, na ilha ${ }^{216}$.

Em 1991, nos Estados Unidos e na Suíça, populações de cervos selvagens foram infectadas por M.bovis, pelos bovinos locais ${ }^{61}$.

Em 1917, Griffith registrou na Inglaterra um caso de infecção natural com $M$. bovis em uma jovem cabra, criada com leite de vaca, e disse que este foi, aparentemente, o primeiro caso de tuberculose natural em cabra, na qual o tipo de bacilo da tuberculose foi determinado ${ }^{216}$. Porcos, cabras e carneiros, usualmente são infectados ao pastarem em íntimo contato com bovinos infectados. Apesar de cabras serem susceptíveis ao M.bovis, a doença é incomum nesses animais ${ }^{87}$.

Em 1955, Milne aplicou o teste da tuberculina em um rebanho de 100 cabras em Tanganyika, Uganda, na África e uma cabra tuberculosa foi encontrada na autópsia. Cinco delas foram reatoras à tuberculina e tinham lesões, predominantemente, do tipo respiratório. As cabras haviam sido abrigadas com bovinos durante a noite, para protegerem-se de carnívoros selvagens, e assumiu-se que esta foi a causa da infecção ${ }^{216}$.

Em 1989, na Austrália, foi detectada tuberculose generalizada em uma vaca de um rebanho de 78 cabeças de gado, criado em íntimo contato com um rebanho de 80 cabras, principalmente leiteiras, e que sempre pastavam juntos. Após a confirmação da tuberculose, pelo isolamento de M.bovis na vaca infectada, 19 (5 fêmeas e 14 machos) das 80 cabras foram removidas da fazenda e testadas com um teste tuberculínico cervical intradérmico, utilizando PPD bovino. Após a leitura do teste, todos os animais foram sacrificados, e o M.bovis foi isolado do linfonodo mediastínico anterior de uma das cabras. Este foi o primeiro registro de tuberculose por M.bovis em uma cabra, na Austrália ${ }^{87}$. 
Nesta amostra limitada de 19 animais, a prevalência da infecção por M.bovis em cabras foi 5,3\%, comparada com 38,5\% nos bovinos. Essa baixa prevalência em cabras sugeriu que esses animais eram menos susceptíveis ao M.bovis que o gado, apesar de que poderia ter havido outras causas como diferenças na exposição ou, talvez, mais provavelmente, a combinação de ambos os fatores ${ }^{87}$.

Este caso enfatizou a recomendação de que onde a tuberculose bovina for detectada, outros animais domésticos em contato com os bovinos infectados devem ser investigados, na busca de infecção por M.bovis ${ }^{87}$.

A principal rota da infecção no suíno é a via oral, por consumo de leite ou produtos lácteos, sobras de comida e carnes de abatedouros, e excretas de bovinos tuberculosos. Em janeiro de 1964, um porco abatido em Ontario, Canadá, apresentou lesões tuberculosas, e posteriormente outros 11 suínos foram encontrados tuberculosos. Esses animais haviam sido alimentados com leite cru proveniente de um rebanho de 59 bovinos de corte e leiteiros, no qual 16 animais apresentaram lesões tuberculosas ${ }^{283}$.

Em 1981, seguindo a confirmação de infecção por M.bovis em um grande rebanho de gado de corte na ilha Havaiana de Molakai, o M.bovis foi isolado de 9 (15\%) dos 61 suínos selvagens (Sus scrofa) que habitavam a mesma propriedade ${ }^{216}$.

Cachorros e gatos são infectados por M.bovis, pelo consumo de leite cru ou carcaças infectadas ${ }^{87}$. A infecção por M.bovis em gatos, tem sido atribuída à ingestão de leite não pasteurizado contaminado, na Grã-Bretanha e Estados Unidos; e ao consumo de carnes e vísceras de animais tuberculosos, na Austrália ${ }^{287}$.

Foi relatado que nas fazendas onde ocorreram severos surtos de infecção por M.bovis em rebanhos de bovinos na Pennsylvania, nos Estados Unidos, durante o período de 1966 a 1988, $4(44,4 \%)$ de 9 cachorros e $24(46,2 \%)$ de 52 gatos que viviam nessas propriedades, foram encontrados com tuberculose. Estes animais viviam exclusivamente nos estábulos, e eram sujeitos a uma considerável exposição aos bovinos tuberculosos que apresentavam, principalmente, lesões pulmonares ${ }^{216}$.

Em 1990, ocorreu o primeiro caso de tuberculose bovina em búfalos da 
espécie Syncerus caffer no Kruger National Park, em Uganda, África. O caso índice foi um búfalo de 2 anos de idade, encontrado doente, e exames post mortem realizados em 57 búfalos provenientes de 2 rebanhos que haviam estado em íntimo contato com o caso inicial, revelaram $9(15,8 \%)$ animais com lesões compatíveis com tuberculose. Entretanto, o isolamento do M.bovis só foi possível em 2 desses animais. A fonte de infecção deste surto não foi descoberta, mas suspeitou-se de bovinos criados em fazendas vizinhas ao parque, e que sofreram surtos epidêmicos em 1960 e no período de 1982 a 1984. Esses bovinos haviam tido um contato muito próximo com os búfalos do parque, e a transmissão da tuberculose bovina, do gado para os búfalos, poderia ter ocorrido durante os surtos nas fazendas e permanecido em níveis indetectáveis durante anos, até que a prevalência nos rebanhos de búfalos aumentasse significativamente ${ }^{30}$.

Desde 1993, muitas focas têm sido encontradas mortas ao longo da costa ocidental Australiana, e exames post mortem preliminares sugeriram infecção tuberculosa por M.bovis, o que aumenta a possibilidade do M.bovis ser endêmico entre a população de focas, pelo menos em águas australianas. $\mathrm{O}$ fato do M.bovis ser ainda tão endêmico entre bovinos no sudoeste da Austrália, quanto na década de 70, e suas carcaças tuberculosas estarem sendo lançadas ao mar, aumenta a probabilidade de transmissão do M.bovis para focas ${ }^{263}$.

\subsection{4- HUMANO PARA HUMANO}

Há evidências na literatura de que o bacilo bovino é transmitido de homempara-homem e de homem-para-bovino, e que o homem é um potencial reservatório e fonte do bacilo da tuberculose bovina $42,67,68,89,216,298$. A propagação homem-parahomem do M.bovis tem sido reconhecida, mas a opinião majoritária é de que esse deve ser um raro evento $36,67,68,89,127,163,196,216,298$. Segundo Jensen, em 1940, não havia razões para se duvidar que uma pessoa com tuberculose pulmonar devida ao M.bovis, era tão contagiosa para seus companheiros como uma pessoa com similar lesão causada pelo M.tuberculosis, apesar de que em seus experimentos, pacientes com doença pulmonar devida a cepas bovinas, excretavam menos bacilos em seus 
escarros que pacientes infectados com cepas humanas ${ }^{68}$.

Collins e col. $(1982)^{67}$, disseram que, se a tuberculose pulmonar devida a cepas humanas e bovinas eram indistinguíveis clinicamente, radiologicamente e patologicamente, seria incoerente assumir uma diferença significante na infectividade dos 2 tipos de bacilos. Eles são da opinião, que as designações "humana" e "bovina" apenas dão maior ênfase a associações com hospedeiros mamíferos diferentes ${ }^{67}$.

O principal problema em provar que a transmissão acontece, é que a tuberculose positiva bacteriológicamente apenas ocorre na minoria dos infectados e, freqüentemente, não antes de muitos anos de infecção ${ }^{129}$. A recente introdução de métodos de biotipagem para cepas bovinas da tuberculose poderá auxiliar na determinação da fonte de infecção dos casos encontrados ${ }^{67,89}$.

Apesar do M.bovis ser responsável por menos que $1 \%$ de todos os isolamentos micobacterianos nos Estados Unidos, o trato respiratório foi envolvido em 39 a 89\% dos pacientes registrados, nas últimas três décadas. Esta substancial proporção de pacientes com infecção pulmonar ativa sugere fortemente que a transmissão aerógena humano-para-humano pode estar ocorrendo ${ }^{92}$.

Alguns casos contemporâneos da Grã-Bretanha, Suécia, Canadá, Holanda e Austrália, confirmam a transmissão aerógena inter-humana ${ }^{92,216}$. Não é lógico assumir que o M.bovis pode ser transmitido por aerossóis de bovinos infectados, mas não de pessoas com lesões pulmonares ou infecção do trato gênito urinário $^{68,92,110,216,266}$.

Griffith e Munro em 1935, na Inglaterra, descreveram um caso entre um homem que foi diagnosticado com tuberculose por M.bovis em 1929, mas que apresentava tosse desde a época de seu casamento em 1923, e sua esposa que apresentou a doença pelo mesmo agente etiológico em 1928, após o terceiro parto. Os autores consideraram o isolamento do bacilo bovino no escarro de ambos os doentes, uma indicação muito sugestiva de contágio familiar, por via inalatória ${ }^{110}$.

Posteriormente, foi registrado outro caso em Liverpool, no qual uma criança que nunca havia ingerido leite não pasteurizado e sofrendo de broncopneumonia 
tuberculosa, teve o M.bovis isolado do escarro. Como ela convivia com a avó paterna, que também sofria de tuberculose pulmonar por M.bovis, sugeriu-se que a criança havia sido infectada pela avó ${ }^{110}$.

No sudeste da Inglaterra, a transmissão humano-para-humano do M.bovis foi constatada. No período de 1977 a 1979, Collins e col. (1981) ${ }^{66}$ isolaram cepas de M.bovis em 137 (2,7\%) dos 5.021 novos casos de tuberculose, registrados no PHLS Regional Centre for Tuberculosis Bacteriology, em Dulwich. E no período de 1977 a 1982, Yates (1984) $)^{297}$ isolou o M.bovis de 268 pacientes (2,8\%) dos 9.568 novos casos de tuberculose, registrados no mesmo laboratório. A origem étnica, a distribuição por idade e sexo, e os sítios de localização da doença, foram analisados em ambos os estudos, de acordo com os dados obtidos pelo referido laboratório, em pacientes de origem étnica européia e afro-asiáticos infectados com cepas bovinas $^{66,216,297}$.

Ambos demonstraram que a doença atingia imigrantes mais jovens, sendo que a tuberculose ocorria mais freqüentemente, por volta dos 20-30 anos de idade nos afro-asiáticos e aos 50-80 anos nos europeus. Quanto ao sexo, nos europeus ocorria mais em homens, e nos imigrantes não houve uma diferença significativa entre homens e mulheres ${ }^{66,297}$.

No estudo de Collins e col., entre os pacientes de origem européia infectados com cepas de M.bovis, havia $44 \%$ de envolvimento pulmonar e $56 \%$ extrapulmonar, sendo $26 \%$ de localização renal. Nos pacientes de origem afro-asiática, a proporção era de $40 \%$ para a infecção pulmonar e $60 \%$ extrapulmonar, sendo $10 \%$ de localização renal ${ }^{66,216}$.

No estudo de Yates, foram analisadas 147 cepas de pacientes de origem européia e 121 de origem afro-asiática. Nos pacientes de origem européia, houve 69 (47\%) casos de doença pulmonar e 78 (53\%) casos, extrapulmonar. Houve envolvimento renal em 32 (22\%) dos 147 pacientes europeus. Nos pacientes de origem afro-asiática, doença pulmonar e extrapulmonar ocorreu em $62(51,2 \%)$ e 58 $(48,8 \%)$ pacientes, respectivamente, sendo que tuberculose renal atingiu $5(4,1 \%)$ dos 121 pacientes $^{297}$. 
Não se descobriu a fonte de infecção para esses casos, mas considerou-se que algumas cepas bovinas foram transmitidas de humano para humano, pela via respiratória, uma vez que uma criança de 6 anos de idade apresentou tuberculose pulmonar devida ao M.bovis ${ }^{297}$.

Em um estudo bacteriológico de linfadenite tuberculosa realizado por Grange e col., em 1982, no sudeste da Inglaterra, encontrou-se que a maioria dos casos de tuberculose entre europeus, devidos às cepas bovinas, ocorreram em indivíduos maiores de 5 anos de idade e com alta incidência de doença pulmonar, sendo muito semelhante aos casos devidos à cepas humanas, que também ocorreram em indivíduos jovens. A explicação provável foi a de que os casos de tuberculose bovina eram devidos à reativação da doença adquirida muitos anos antes, enquanto novas infecções causadas por cepas humanas, ainda ocorriam ${ }^{68}$.

Grange e col. concluíram que apesar da incidência total da doença bovina no homem estar diminuindo, a incidência relativa de lesões pulmonares parecia estar aumentando. Uma provável explicação para essas observações foi que a transmissão humano-para-humano da tuberculose bovina estava ocorrendo. Se esse foi o caso, os autores acreditam que este tipo de transmissão da infecção poderá tornar-se predominante, no futuro, nos lugares onde a passagem do tempo eliminar os casos devidos à reativação. E recomendaram que, em vista do grave risco que o gado com tuberculose bovina representava para o homem, a possibilidade de que o homem poderia, pela passagem da infecção de pessoa-para-pessoa, tornar-se um reservatório do bacilo da tuberculose bovina, deveria ser seriamente considerada ${ }^{68}$.

Em 1942, Hedvall e Magnusson publicaram um estudo realizado na Suécia, no qual um caso convincente de infecção humano-para-humano havia ocorrido em uma garota de 7 anos de idade, contaminada pela irmã mais velha, que apresentava tuberculose pulmonar cavitária causada pelo M.bovis ${ }^{266}$.

Em 1966, em Ontario, Canadá, uma mulher de 27 anos apresentou tuberculose pulmonar avançada, devida ao M.bovis. Em uma investigação inicial, seu filho de 2 anos foi não reativo ao teste da tuberculina, mas 3 meses depois seu teste havia convertido e sua radiografia torácica revelou linfonodos aumentados. Como ele 
nunca havia ingerido leite não pasteurizado e não havia tido contato com qualquer outra possível fonte de infecção, provavelmente sua infecção foi causada por M.bovis adquirido, por transmissão aerógena, de sua mãe ${ }^{283}$.

Um exemplo convincente de transmissão pessoa-a-pessoa ocorreu na Austrália, no caso de contato de um paciente de 44 anos com um de 42 anos com tuberculose pulmonar cavitária e uma história de ingestão de leite não pasteurizado na infância ${ }^{216}$.

Em 1994, um pequeno surto de tuberculose causada pelo M.bovis, o qual provavelmente envolveu a transmissão de humanos-para-humanos, foi descrita em Amsterdam, na Holanda, onde 153 cepas de M.bovis provenientes do gado, de várias espécies animais de zoológicos e parques, e de humanos, foram analisadas por 3 diferentes marcadores genéticos, de uso na epidemiologia da tuberculose bovina. Surpreendentemente, 5 cepas de M.bovis foram isoladas em humanos, sendo que 3 delas em membros de uma mesma família, 1 em um morador do mesmo prédio de apartamentos, e a outra em um morador da mesma província, e todos apresentavam a mesma seqüência de DNA IS6110. Entretanto, não pode ser estabelecida uma relação epidemiológica. Aparentemente, no mínimo 4 cepas foram provenientes de um pequeno surto entre humanos, uma vez que essas pessoas não tinham contato freqüente com animais domesticados ou não ${ }^{216,254}$.

Uma das questões ainda não respondidas, entre as várias formuladas recentemente, a respeito da transmissão inter-humana da infecção por M.bovis é que, se esse tipo de transmissão realmente ocorre, a possibilidade desta forma de tuberculose persistir na população humana na ausência de um reservatório animal da doença, seria viável ${ }^{127}$.

A doença humana primária devida ao M.bovis é muito rara em países desenvolvidos, onde a tuberculose bovina tem sido erradicada, mas a transmissível forma pós-primária (reativação) da doença é ainda encontrada, sendo que quase todos os casos têm sido confirmados em pessoas nascidas antes que os esquemas de erradicação fossem completados 90, 127, 130, 249, 295, 296 . Outro importante fator adicional que estes países estão enfrentando atualmente é a epidemia HIV/AIDS, que favorece 
a transmissão humano-para-humano do M.bovis, conduzindo rapidamente à doença aparente ${ }^{127,196}$. Embora as infecções devidas a cepas de M.tuberculosis multidrogaresistentes sejam bem conhecidas, este é um evento raro para as cepas de M.bovis ${ }^{85,249}$.

Apenas 1 a 3\% dos casos de tuberculose em indivíduos HIV infectados ou não infectados no mundo ocidental, é causado pelo M.bovis ${ }^{249}$.

Casos de HIV relacionados à tuberculose humana devida ao M.bovis têm sido relatados na Inglaterra, França e Estados Unidos (sul da Califórnia) 36, 216, 295, 296. A transmissão inter-humana da doença causada pelo M.bovis em pessoas HIVpositivas, tem sido confirmada recentemente ${ }^{36,89,295,296}$.

No caso da infecção pelo M.bovis no homem, de origem animal ou humana, é extremamente provável que alguns fatores imunes que previnem o desenvolvimento da doença pós-primária ou a transmissão homem-para-homem, sejam anulados em pacientes HIV/AIDS, ocasionando uma doença evidente e progressiva $89,90,127,129,130$, 216. Então, em regiões com alta prevalência de HIV-positivos, os ciclos de transmissão da doença, do gado para o homem, do homem para o homem e do homem para o gado, poderiam ser estabelecidos e perpetuados $89,90,129,130,159,295,296$.

Por isso, há uma séria preocupação de que a pandemia pelo HIV poderia resultar em um aumento da tuberculose humana devida à infecção por M.bovis, e que um maior grau de transmissão da infecção para outros seres humanos e animais domésticos ou de criação poderia ocorrer ${ }^{89,90,129,159,196,216 .}$

O primeiro informe de tuberculose por M.bovis em pacientes HIV-positivos, foi proveniente da França, onde esse bacilo foi a causa de 2 (1.6\%) dos 123 casos de tuberculose em pacientes HIV-positivos ${ }^{129,196,216}$. Como as cepas do M.bovis são naturalmente resistentes à pirazinamida, é de particular significância que aqueles franceses, nos quais foi isolado o M.bovis, eram resistentes também à isoniazida, pois duas das drogas antituberculosas de $1^{\text {a }}$ linha, foram ineficientes nessas pessoas ${ }^{196,216}$.

A ocorrência da transmissão humano-para-humano da doença foi inequivocamente demonstrada por um surto hospitalar em Paris, França, descrito por 
Bouvet e col. $(1993)^{41}$, onde um único paciente HIV-positivo com tuberculose pulmonar devida a uma cepa multidroga-resistente de M.bovis, foi a fonte de infecção para 5 pacientes e um médico, que desenvolveram doença ativa no período de 3 a 10 meses e 27 meses respectivamente, após o contato 36, 41, 90, 129, 130, 216, 296.

Um homem de 31 anos HIV-positivo que havia retornado de uma viagem de 6 meses pelo Brasil e não era fazendeiro ou trabalhador de abatedouro, foi admitido em setembro de 1989 no Hospital Bichat-Claude Bernard em Paris. Ele abrigava uma cepa de M.bovis resistente a isoniazida, rifampicina, etambutol, estreptomicina, pirazinamida, etionamida e rifabutina, e morreu em janeiro de 1990. Entre fevereiro de 1990 e outubro de 1991, essa cepa multidroga-resistente foi diagnosticada em outros 5 (3 homens e 2 mulheres) pacientes HIV-positivos que haviam sido hospitalizados na mesma unidade de tratamento, entre setembro de 1989 e outubro de 1991, sendo que um deles havia sido admitido enquanto o caso índice estava na unidade. Todos os 5 pacientes faleceram de tuberculose incontrolável apesar do tratamento aplicado, confirmando que a duração do contato foi um importante fator para a transmissão hospitalar entre eles ${ }^{41,275}$.

Em janeiro de 1992, um médico HIV-negativo, que havia estado em íntimo contato com o caso índice, apresentou tuberculose pela mesma cepa de M.bovis multidroga-resistente. O período de incubação de 27 meses foi considerado longo em relação aos outros pacientes, sendo que ele apresentou um quadro clínico similar, com envolvimento predominantemente pulmonar, confirmando que acima de $30 \%$ dos contatos poderiam adquirir a nova cepa, e que 5-10\% desses, desenvolveriam tuberculose em poucos anos. A resistência a pirazinamida é inata ao M.bovis, mas resistência primária a drogas antituberculosas de $1^{\text {a }}$ linha, é incomum ${ }^{41}$.

A detecção da transmissão do caso índice para os casos secundários, foi facilitada pelo fato de que a cepa envolvida era rara e com características drogaresistentes, incomuns. Além disso, todos os casos tinham aspectos clínicos que sugeriam uma tuberculose primária (recentemente adquirida) com envolvimento predominantemente pulmonar $^{41}$.

Este estudo sugeriu que houve um surto de tuberculose, devido à transmissão 
hospitalar de uma única cepa de M.bovis multidroga-resistente, e que infecções por M.bovis, recentemente adquiridas, poderiam progredir rapidamente para tuberculose, em pacientes infectados pelo $\mathrm{HIV}^{41}$.

Este surto demonstrou também três fatores preocupantes da tuberculose por M.bovis relacionados ao HIV: primeiramente, que a transmissão humano-parahumano, conduzindo a uma doença evidente, definitivamente ocorre; segundo, que o intervalo entre infecção e doença evidente é curto e terceiro, que doenças de cepas resistentes a multidrogas podem ser geradas e disseminadas ${ }^{41,129}$.

Apesar das técnicas de biologia molecular ainda não serem consideradas totalmente confiáveis, para o diagnóstico definitivo da tuberculose, por necessitarem de maiores avaliações, Vincent $(1994)^{275}$, na França, descreveu o mesmo surto hospitalar, por cepas de M.bovis multidroga-resistentes, ocorrido em 1993, e surpreendentemente, no final de seu artigo, afirmou que: "Previamente identificadas como M.bovis, segundo os critérios bioquímicos de identificação usuais, as cepas foram reconhecidas como M.tuberculosis, graças à utilização de marcadores genômicos mpt $40^{275}$.

Em um estudo clínico epidemiológico da infecção por M.bovis em San Diego, Califórnia, Estados Unidos, em um período de 12 anos (1980-1991), 13 (17.8\%) dos 73 pacientes infectados por M.bovis eram HIV-positivos 92, 129, 154, 216 , sendo que 12 casos foram identificados nos últimos 3 anos de estudo, ou seja, no período de 1989 a 1991. Esses dados sugeriram uma susceptibilidade de pacientes aidéticos a essa micobactéria, e salientaram a importância de se considerar o M.bovis como causa de doença pulmonar e extrapulmonar em aidéticos ${ }^{92,216 .}$

Entre junho de 1985 a dezembro de 1991, foram analisadas 2.521 amostras biológicas provenientes de 1.259 pacientes HIV-positivos ou com AIDS, em um hospital de Buenos Aires, Argentina. Desse total, 1.133 (45\%) amostras eram de origem pulmonar e 1.388 (55\%), extrapulmonar. Confirmou-se doença micobacteriana por meio de cultura em 240 (19\%) dos 1.259 pacientes. O M.tuberculosis foi isolado em 223 (92,9\%) dos casos e o M.bovis em 2 (0,8\%); enquanto o complexo M.avium (MAC) foi identificado como causa da doença em 14 
pacientes $(5,8 \%)$ e o M.kansasii em $1(0,4 \%)$ caso ${ }^{95}$.

São citados ainda 2 casos de infecção por M.bovis entre os 167 casos de tuberculose em pacientes HIV-positivos no sudeste da Inglaterra, entre 1984 e 1992. Um deles em uma mulher de 32 anos de idade que desenvolveu tuberculose pulmonar em 1989. O outro, em um homem de 49 anos que apresentou linfadenopatia cervical em $1991^{89,127,129,216 .}$

Em 1993, na Alemanha, ocorreu o primeiro caso de infecção disseminada por M.bovis em um paciente com meningite e AIDS, homossexual, de 54 anos, que relatou a ingestão de leite não pasteurizado durante sua infância na Inglaterra. $O$ M.bovis foi isolado do sangue, medula óssea, fezes, urina, escarro, linfonodos abdominais e fluido cérebro-espinhal. Após a terapia antituberculosa usando 5 drogas, o paciente obteve completa recuperação em $1994{ }^{1}$.

O companheiro desse paciente, um homem de 48 anos e HIV-positivo que recusou o tratamento profilático com isoniazida, desenvolveu tuberculose pulmonar por M.bovis 3 meses depois. Acreditou-se que a infecção por M.bovis do primeiro paciente tenha ocorrido por transmissão hospitalar de uma cepa multidroga-resistente e a propagação para o seu companheiro, demonstrou que a transmissão humano-parahumano também ocorria em pacientes com infecção por M.bovis ${ }^{1}$.

Registrou-se também um caso de linfadenite tuberculosa causada por M.bovis em uma mulher HIV-positiva, de 25 anos e usuária de droga intravenosa, e outro em um alemão, homossexual, de 42 anos, HIV-positivo e que havia viajado extensivamente a países mediterrâneos, África e América do Sul. Neste caso o M.bovis foi isolado de linfonodo cervical ${ }^{1}$.

Um caso de infecção por uma cepa de M.bovis multidroga-resistente foi descrito na Holanda, em 1995, em um homossexual de 47 anos e origem alemã, que era soropositivo para HIV desde 1987. Em maio de 1995 foi diagnosticada uma tuberculose pulmonar por uma cepa do complexo M.tuberculosis, e após 40 dias de tratamento, o paciente faleceu repentinamente. A autópsia e análises bioquímicas do escarro revelaram que a cepa isolada era M.bovis. A cepa era resistente à isoniazida, 
rifampicina, rifabutina, estreptomicina, amicacina, pirazinamida, etionamida, claritromicina e ciprofloxacin. Não foi esclarecida a fonte de infecção, mas acreditase que a transmissão ocorreu durante uma pequena internação do paciente em um hospital na Espanha, em janeiro de $1995^{249}$.

Blázquez e col. $(1997)^{36}$ comunicaram que no período de dezembro de 1993 a fevereiro de 1995, ocorreu um surto de tuberculose causada por cepas de M.bovis multidroga-resistentes, em 19 pacientes infectados pelo HIV, no hospital Ramón y Cajal em Madri, Espanha, atingindo 16 homens e 3 mulheres com idades entre 24 e 54 anos. $\mathrm{O}$ caso índice e outros 2 pacientes haviam sido anteriormente atendidos em um outro hospital de Madri, que apresentava uma epidemia de tuberculose por cepas multidroga-resistentes de M.tuberculosis. Os outros 16 pacientes foram expostos, na ala de doenças infecciosas do hospital Ramón y Cajal, a um dos 3 pacientes. Todos os pacientes morreram, apesar do tratamento com múltiplas drogas antituberculosas de $1^{\mathrm{a}}$ e $2^{\mathrm{a}}$ linhas ${ }^{36}$.

Também neste caso, os autores declararam que, no início do surto suspeitouse que as cepas eram de M.tuberculosis, mas análises realizadas por uma nova técnica de biologia molecular (Spoligotyping) confirmaram que todas as cepas eram de M.bovis multidroga-resistentes; e ainda afirmaram que esta havia sido a primeira caracterização, em nível molecular, de um surto por cepas multidroga-resistentes de M.bovis em um hospital, envolvendo a transmissão inter-humana entre pacientes aidéticos ${ }^{36}$.

A tuberculose bovina em pacientes HIV-positivos tem sido registrada em 94 (69\%) dos 136 países nos Trópicos ${ }^{216}$.

Apesar de não haver relatos de infecção por M.bovis em infectados por HIV ou em casos de AIDS na África, taxas de soroprevalência de HIV de mais de $40 \%$ foram encontradas em pacientes tuberculosos, em vários países africanos ${ }^{216,274,295}$. Assim, as conseqüências da tuberculose animal na população humana na África, podem estar sendo subestimadas ${ }^{274}$.

A patogenicidade do M.tuberculosis para o homem é sobejamente conhecida, 
sendo a tuberculose pulmonar responsável por 95\% dos casos devido ao contágio inter-humano, que se faz por via aérea ${ }^{236}$.

\subsection{5- HUMANO PARA BOVINO}

O homem com tuberculose pulmonar devida a cepas bovinas é considerado como a principal fonte de infecção e representa um gravíssimo risco para o bovino, existindo muitos casos de transmissão da doença para rebanhos inteiros, resultante de apenas um trabalhador rural infectado; mas esse risco é freqüentemente subestimado por autoridades médicas e veterinárias, especialmente nos países livres da tuberculose bovina $68,127,174,196,199,266$.

No início do século XX, muitos casos de tuberculose devida ao M.bovis ocorreram em crianças e adultos jovens. A maioria dos casos eram extrapulmonares e envolviam os linfonodos cervicais, ossos e articulações, abdômen e pele, mas doença gênito-urinária era muito rara. A doença pulmonar devida ao M.bovis também era incomum ${ }^{127}$.

Hoje, a doença pulmonar é mais prevalente, apesar de ainda ocorrerem casos extrapulmonares, aumentando a probabilidade de transmissão do bacilo para outra pessoa e para o bovino, pela via aerógena. $\mathrm{O}$ trato gênito-urinário é agora o principal sítio das lesões não-pulmonares devidas ao M.bovis, e existe forte evidência de que esta forma de tuberculose proporciona um risco para o bovino ${ }^{127}$.

Existem três possíveis explicações para a presente alta incidência de doença pulmonar, em contraste com a situação de poucas décadas atrás:

a) O pulmão deve ser o usual sítio da tuberculose pós-primária, independentemente do sítio da lesão primária. (No início do século, havia debates consideráveis, no sentido de esclarecer se a tuberculose pulmonar era o resultado de uma infecção primária do pulmão ou se ela era secundária a uma infecção inicial via trato digestivo.). Se este é o caso, então na época em que a tuberculose humana de origem bovina era freqüente, seria esperada além de uma alta incidência de doença 
extrapulmonar em pessoas jovens, também uma alta incidência de doença pulmonar em pessoas idosas, o que não ocorreu ${ }^{127}$.

b) A doença pulmonar pode representar uma reativação de infecções pulmonares primárias "silenciosas". Apesar de o leite ter sido o vetor usual da tuberculose bovina em habitantes urbanos, que geralmente desenvolviam doença primária extrapulmonar, trabalhadores rurais algumas vezes adquiriam a infecção primária pela via aerógena, diretamente de vacas tuberculosas. Em algumas regiões, o risco de se infectarem pelo leite foi eliminado pela introdução da pasteurização, mas ainda existem trabalhadores rurais que desenvolvem tuberculose pulmonar, devida a uma infecção aerógena direta do gado ${ }^{127}$.

c) Os casos podem ser o resultado direto da transmissão humano-para-humano da doença $^{127}$.

O primeiro caso de transmissão da infecção por M.bovis do homem para o bovino, foi descrito por Magnusson, em $1937^{266}$.

A transmissão da infecção pelo M.bovis de humanos para o bovino é usualmente direta e pela via respiratória, mas a propagação indireta via cama de palha e/ou feno contaminado nos estábulos com urina de humanos doentes com tuberculose do trato gênito urinário, tem sido registrada no Canadá, Dinamarca, Holanda, Suécia e Alemanha 42, 89, 110, 127, 129, 148, 173, 199, 216, 228, 266, 283, 298.

No caso de transmissão pela urina de humanos, ela pode ser aerolizada ou ingerida pelo gado, uma vez que a doença do trato gênito urinário é uma manifestação comum da infecção por M.bovis em adultos, e esta rota é provavelmente um importante meio de infecção para rebanhos não infectados ${ }^{92}$.

A tuberculose gênito-urinária no homem tende a seguir um curso crônico, com vagos sintomas, e o diagnóstico é muitas vezes tardio. De fato, alguns casos em trabalhadores rurais são diagnosticados somente depois que o gado tenha se tornado infectado ${ }^{127}$.

Em 1941, na Suécia, uma ordenhadora infectou 49 animais, em 6 semanas. 
Por esse motivo, reconheceu-se a necessidade de se examinar todas as pessoas cujas ocupações envolvessem contato com bovinos; mas esse plano foi considerado impraticável na ocasião, porque seria necessário examinar 300.000 pessoas ${ }^{110}$.

Na Dinamarca, entre 1943 e 1952, 107 de 299 pacientes com tuberculose devida ao M.bovis (193 dos quais tinham doença pulmonar), foram a fonte de infecção para bovinos em 128 rebanhos, resultando no abate de 1.182 animais ${ }^{127,216}$.

Na Holanda, 50 rebanhos de gado foram infectados pelo M.bovis proveniente de humanos. Um total de 636 bovinos reatores a tuberculina foram identificados, dos quais 497 (78\%) foram confirmados post mortem, como infectados por M.bovis. Das 50 pessoas que estavam infectadas pelo M.bovis, 24 (48\%) tinham tuberculose urogenital e os outros $26(52 \%)$ tuberculose pulmonar ${ }^{216}$.

Na Alemanha, a infecção no bovino por M.bovis é rara, mas quando ocorre, a transmissão homem-para-vaca é a causa principal. Em uma pesquisa, 12 pacientes tinham infectado 114 cabeças de gado em 16 rebanhos diferentes, sendo que 9 das 12 (75\%) pessoas tinham tuberculose gênito-urinária, e um único paciente infectou 48 cabeças de gado em 4 rebanhos diferentes ${ }^{127,216,298 .}$.

Em junho de 1964, em Ontario, Canadá, uma vaca apresentou pequenas lesões caseosas no exame post mortem, sendo que no ano anterior ela era tuberculinanegativa nos testes realizados rotineiramente em seu rebanho. $\mathrm{O}$ fazendeiro admitiu que ele deveria ser a fonte de infecção, porque em 1963 ele estava com tosse e hemoptise, mas não havia consultado um especialista até sofrer uma avançada tuberculose pulmonar por M.bovis. Como nenhum suíno ou aves domésticas haviam sido criados na fazenda nos últimos 8 anos e a tuberculose bovina no fazendeiro era muito extensa, houve uma forte suspeita de que ele realmente foi a fonte de infecção para o rebanho 283 .

Apesar de infecções pelo M.tuberculosis, provenientes de humanos, terem sido reportadas em bovinos, a doença não é progressiva e as lesões são usualmente pequenas e delimitadas $2,148,174,216,228,237,266$. O bovino é resistente ao M.tuberculosis, o qual, geralmente, não determina lesões anátomo patológicas e 
apenas o sensibiliza à tuberculina. Em algumas ocasiões tem sido possível isolar M.tuberculosis dos gânglios de alguns animais reatores à tuberculina que não apresentavam lesões no exame post mortem. É pouco provável que bovinos infectados com M.tuberculosis possam transmitir a doença ao homem, apesar de ser infectado por uma pessoa doente. No entanto, mesmo que a infecção nos bovinos não seja progressiva, o bacilo pode permanecer viável por algum tempo nos órgãos e tecidos e ser excretado pelo úbere da vaca sem sinais de infecção ou inflamação, cujo leite atuará como uma fonte de infecção para bovinos e seres humanos $2,8,68,174,272,282$.

\subsection{6 - HUMANO PARA RESERVATÓRIOS ANIMAIS}

O homem pode contrair a tuberculose por M.bovis de diferentes animais e, igualmente, transmitir-lhes a infecção 4, 74, 89, 92, 174, 295, 296 . Entretanto, não foram localizadas informações mais detalhadas sobre esta transmissão, nas publicações nacionais e internacionais consultadas para a realização deste trabalho. São mais freqüentes as publicações a respeito da transmissão humano-para-reservatórios animais referentes à infecção por M.tuberculosis.

Sabe-se que cães e gatos são susceptíveis à infecções por M.bovis e M.tuberculosis. As infecções causadas pelo M.tuberculosis são consideradas uma zoonose inversa, ou seja, a direção da transmissão é do homem para o animal, cuja prevalência é maior nos cães do que em gatos ${ }^{131,157}$. No caso do cão, companheiro de um homem excretor eventual de bacilos, a contaminação ocorre, principalmente, por inalação ${ }^{117}$. Portanto, cães e gatos, podem ser potenciais disseminadores do M.bovis e a doença nesses animais se localiza, preferencialmente, no trato respiratório e no intestino, respectivamente ${ }^{131}$. Nas 2 espécies animais, a doença é de evolução rápida e caquetizante, na ausência de tratamento ${ }^{117}, 131$. Devido à localização da infecção, os cães geralmente excretam o bacilo no escarro e os gatos, nas fezes ${ }^{131}$.

Portanto, cães e gatos em íntimo contato com humanos que apresentem uma tuberculose ativa, adquirem a doença ${ }^{174}$, tornando-se portadores do bacilo e podendo 
transmití-lo a outros animais ou retransmití-lo ao homem. Por esse motivo, qualquer que seja o responsável pela contaminação, o proprietário ou o animal, o diagnóstico da tuberculose em um animal de convivência familiar, implica na sua eutanásia ${ }^{270}$.

Até 1992, pouca atenção era dispensada à tuberculose em pequenos animais. Como a tuberculose canina frequentemente é um indicador da doença em humanos, sua detecção precoce nesses animais, é essencial para a saúde pública ${ }^{60}$.

A infecção pelo M.tuberculosis está confinada quase que exclusivamente ao homem e primatas cativos (domiciliados), sendo o homem uma fonte de infecção para primatas não humanos $216,260,261$. Por isso, precauções devem ser tomadas para minimizar a exposição desses animais a seres humanos. O estado de saúde dos zeladores e guardas de zoológicos e parques animais, deve ser determinado antes do manejo desses animais, por meio de radiografias e testes tuberculínicos periódicos 260, 261 . Entretanto, a tuberculose em cervos, causada pelo M.tuberculosis, tem sido encontrada em parques animais e zoológicos da Índia e em zoológicos em Taiwan ${ }^{134}$. Clercx e col. $(1992)^{60}$ descreveram um caso de tuberculose generalizada por M.tuberculosis em um cão, na Bélgica ${ }^{60}$.

No Brasil, Saliba e col. (1970) ${ }^{244}$, descreveram o $1^{\circ}$ caso de tuberculose espontânea em gato, provocada pelo M.tuberculosis, e Migliano (1970) ${ }^{187}$ escreveu uma extensa revisão bibliográfica sobre tuberculose em cães ${ }^{187,244}$.

\subsection{7- RESERVATÓRIOS ANIMAIS PARA RESERVATÓRIOS ANIMAIS}

A tuberculose causada pelo M.bovis é transmitida entre animais pela inalação de aerossóis infecciosos ou após o consumo de alimento infectado. O íntimo contato que existe entre os animais de zoológicos e parques, favorece a transmissão da doença, a qual ocorre, provavelmente, via aerossóis, fômites, alimento e água, contaminados ${ }^{263}$. A transmissão de animais selvagens para domésticos e entre animais domésticos é predominantemente pela via aérea e ocorre principalmente onde existe interação, devido a comportamentos atípicos, entre um hospedeiro selvagem excretor de bacilos (freqüentemente terminal) e animais domésticos ${ }^{199}$. 
Os dados acumulados de 1972 a 1987 na distribuição e prevalência de tuberculose em populações de texugos da Grã-Bretanha têm sido revistos ${ }^{58,64,125,216}$. Concluiu-se que a infecção por M.bovis é endêmica na população de texugos britânicos e irlandeses e que o texugo é um hospedeiro ideal para a manutenção do M.bovis. ${ }^{58,63,64,100,125,149,180,199,210,216,268}$. A evidência disso, é que texugos vivem em grupos sociais constituídos em média por 6 adultos mais os filhotes, nos quais a infecção se espalha pela transmissão fêmea-para-filhote e por inalação de aerossóis; sobrevivem por relativamente longos períodos enquanto sofrem de franca doença; o tamanho e estrutura da população, e grupos sociais individuais, não são significantemente perturbados pela presença de infecção ou doença, e populações de texugos permanecem infectados na ausência de exposição ao M.bovis de outras fontes $58,64,125,149,210,216$. Além disso, entre 11 e $17 \%$ dos texugos tuberculosos, aparentemente foram infectados através de ferimentos por dentadas em brigas $^{58,62,120,125}$.

Há evidências, embora limitadas, de que a manutenção da infecção é o resultado, não apenas do importante componente que é a transmissão maternal post natal, mas também de que fêmeas são mais importantes que machos na propagação da doença, por causa de seu maior tempo de vida, apesar da prevalência da infecção ser maior em machos, por exercerem um importante papel na defesa de seu território $^{58,120,149,203,216 .}$

Os texugos vivem em grupos sociais de aproximadamente 15 animais com grupos territoriais bem definidos, em um complexo de túneis interligados e compartimentos subterrâneos, a uma distância mínima de 2 metros do solo, de fabricação própria, denominados "setts". Dentro do território existe, usualmente, um sett principal, alguns anexos auxiliares e outros setts mais distantes, que são distinguíveis pela sua estrutura física. As fronteiras territoriais são demarcadas por latrinas e secreções glandulares, para serem defendidas de outros grupos sociais ${ }^{149}$.

Os texugos preferem um solo arenoso para construir seus setts, por isso o ambiente empoeirado desses locais não apenas aumenta o risco da transmissão por aerossol, mas pode comprometer a capacidade imune dos texugos, causando silicose 
no pulmão $120,146,149,210$. A transmissão da infecção também ocorre dentro dos grupos sociais por meio do íntimo contato e acasalamento entre os animais, e do hábito que possuem de distribuírem lambidas e mordiscadas entre si ${ }^{146}$.

Outra possível rota de infecção é através de ferimentos por dentadas, entre machos, como resultado de conflitos territoriais que podem ser realçados pelo comportamento não usual de alguns texugos, induzido por massiva infecção com M.bovis, de desorientação e invasão de territórios vizinhos, facilitando também a transmissão aerógena entre os combatentes $58,120,146,149,199,203,210,216$.

A expectativa de vida de texugos selvagens não é conhecida, mas animais velhos têm sido encontrados no exame post mortem. Texugos cativos costumam viver por mais de 10 anos e pelo menos um caso de um texugo com 18 anos de vida, foi registrado ${ }^{203}$.

Os texugos permanecem infectados por longos períodos de tempo, sendo que um animal foi capaz de sobreviver por 3,5 anos excretando M.bovis, e estudos sugerem que um terço dos animais excretores sobrevive por 12 meses ou mais, com excreções intermitentes ${ }^{62,210}$.

Acredita-se que a susceptibilidade dos texugos à tuberculose, é devida a uma fraca resposta imunológica quando comparados a outras espécies animais ${ }^{149,} 210$. Entretanto, a sobrevivência de texugos infectados por longos períodos, sugere a existência de um mecanismo de controle que, em muitos casos, retarda a propagação dos bacilos da lesão primária, limitando a progressão da doença 62, 149, 209 . Eles permanecem cronicamente infectados, produzem filhotes, ocorrendo a lactação nas fêmeas, e contaminam seu ambiente intermitentemente. Em algum momento esse mecanismo falha, inicia-se uma massiva multiplicação do bacilo, e o animal apresenta um acentuado emagrecimento antes de morrer. A causa desse processo é desconhecida, mas acredita-se que fatores de stress como a falta de comida, contribuam para que ele ocorra ${ }^{62}$.

Durante o verão, os texugos abandonam os setts principais. O pico de atividade é atingido durante a primavera quando ocorrem os acasalamentos, 
coincidindo com o maior risco de transmissão do M.bovis entre colônias de texugos. No inverno, os texugos ocupam somente os setts principais, com pouquíssimo movimento. A ovulação é induzida pelo acasalamento, o qual usualmente ocorre entre fevereiro e maio, mas pode se estender até outubro. O ovo fertilizado é implantado em dezembro e uma só ninhada de 1 a 4 filhotes é produzida, aproximadamente, 8 semanas mais tarde. Fêmeas normalmente amamentam seus filhotes por, no mínimo, 12 semanas. Os filhotes não saem dos setts durante, pelo menos, 2 meses $47,149,210,216$.

Apesar da possibilidade dos texugos contraírem tuberculose por contato com pasto contaminado ou com as fossas das latrinas, a transmissão da infecção pelo M.bovis entre texugos parece ser principalmente pela via respiratória, sendo o pulmão o principal sítio de infecção. Por isso, o M.bovis pode ser detectado em aspirados traqueais ou swabs laríngeos e amostras de fezes, devido à deglutição de escarro infectado. Outros órgãos internos como o fígado, baço e especialmente os rins, são afetados pela propagação hematogênica secundária de lesões pulmonares ou de ferimentos por dentadas ${ }^{62,120,180}$. Consequentemente, os bacilos são encontrados no escarro, fezes, urina e pus de feridas infectadas $58,62,120,125$.

Os animais infectados por dentadas de outros texugos sobrevivem menos que outros infectados por outras vias. Acredita-se que nesse caso, ocorra uma forma de tuberculose que é disseminada pela via hematogênica mais rapidamente ${ }^{62}$.

Apesar de haver uma tendência para uma prevalência aumentada com a idade, a aquisição da infecção ocorre, mais freqüentemente, em animais jovens (0-2 anos), devido à transmissão pseudo-vertical da mãe para o filhote ${ }^{62,120,180,199,203,210,216}$. A taxa de mortalidade para filhotes, especialmente durante o pico de uma epidemia, excede $50 \%{ }^{62}$.

Estudos mais recentes, concluíram que $82 \%$ dos texugos tuberculosos se infectam pela via respiratória e $18 \%$ por ferimentos por dentadas. A transmissão da fêmea para o filhote não pode ser quantificada e permanece ainda obscura a maneira pela qual essa transmissão ocorre, ou seja, se pela via transplacentária, via lactação (também chamada transferência vertical ou pseudo-vertical) ou via íntimo contato 
mãe/filhote dentro dos setts. Qualquer que seja a rota, filhotes acima de 6 meses de idade, podem apresentar tuberculose aguda. Este fato confere a qualquer estratégia de vacinação pouquíssimo sucesso, uma vez que os filhotes são inatingíveis nos 2 primeiros meses de vida em seus túneis subterrâneos ${ }^{146}$.

Gallagher e col., (1976) ${ }^{120}$,demonstraram, na Inglaterra, que $22(61.1 \%)$ dos 36 texugos infectados naturalmente, tinham lesões nos pulmões e cavidade torácica, mas naqueles onde a propagação hematogênica havia ocorrido, o sítio de predileção eram os rins. A infecção renal, com excreção do M.bovis na urina, é muito mais comum nos texugos do que em outras espécies animais e, neste estudo, 37\% dos texugos tuberculosos, excretaram o bacilo na urina ${ }^{120,199}$.

Durante o período de junho de 1981 a agosto de 1988, 28 texugos infectados por M.bovis foram detectados em Gloucestershire, Inglaterra. Evidências clínicas e bacteriológicas sugeriram que a infecção havia sido adquirida por dentadas em apenas 5 texugos $(17,9 \%)$, e os remanescentes $23(82,1 \%)$ haviam sido infectados pela via respiratória ${ }^{58,199}$.

Um estudo de 72 texugos infectados, realizado em 1991, mostrou que o pulmão era o mais freqüente, e constantemente único sítio de isolamento do M.bovis. Esta rota de transmissão é favorecida pela estrutura social desses animais, na qual existe íntimo contato entre eles, dentro dos setts ${ }^{210}$.

Sabe-se que os pulmões e os rins dos texugos, são os sítios de predileção para a tuberculose crônica nesses animais 62, 120, 146, 199 . Entretanto, estudos recentes demonstraram que cerca de $42 \%$ dos texugos tuberculosos adquiriram a infecção inicialmente pela via digestiva, apresentando lesões semelhantes à escrófula nos linfonodos submandibulares ${ }^{146}$. Consequentemente acredita-se em mal-entendidos, por parte dos pesquisadores, a respeito da origem da tuberculose nos texugos. Uma reavaliação da patogênese das tuberculoses iniciais e tardias sugeriram que a tuberculose é muitas vezes adquirida inicialmente pela via digestiva e o rápido desenvolvimento secundário de uma tuberculose pulmonar evidente, tem sido malinterpretado ${ }^{146}$. 
Muitas espécies de mamíferos utilizam-se dos setts dos texugos ${ }^{149}$. Os mamíferos selvagens que compartilham o habitat dos texugos exercem também uma ação predatória e se contaminam através de um contato indireto casual com alimentos nos locais comuns, ou quando habitam os setts abandonados pelos texugos 25 .

Em gambás, na Nova Zelândia, a transmissão pseudo-vertical (entre o nascimento e a independência) respiratória pós-natal, da fêmea para suas crias dependentes, é um importantíssimo método de transmissão e o fator chave para a manutenção da infecção na população local. A íntima associação de mãe e filhote, com apenas 18 dias in utero, mas aproximadamente 5 meses em sua bolsa, seguido por um período de carregá-lo nas costas, expõe os recém-nascidos à mães tuberculosas, com um alto risco de infecção ${ }^{149,199,216}$. Acredita-se que a transmissão aérea horizontal, dentro da comunidade local de gambás, é predominantemente associada com atividades de namoro e acasalamento entre os sexos e competição entre machos $105,149,199,216$.

As tocas dos gambás são construídas em cavidades nas árvores, ou entre troncos e raízes. São escuras, fechadas e empoeiradas, sendo ideais tanto para a sobrevivência do M.bovis fora de um hospedeiro, quanto para a sua transmissão. Eles habitam extensões de áreas que se sobrepõem umas às outras, mas mantêm um sistema de mútua evitação entre os líderes, enquanto se alimentam. Fora das interações que ocorrem entre fêmea-filhote, macho-macho e macho-fêmea (durante o cio), o contato direto gambá-gambá é infreqüente e a transmissão do M.bovis, menos provável. Os gambás utilizam-se, em suas áreas, de 10 a 15 tocas durante o ano, compartilhando-as seqüencialmente com gambás da vizinhança. Além do mais, já foi registrado o uso simultâneo de tocas individuais, por até 5 gambás ${ }^{65}$.

A prevalência da doença em gambás varia sazonalmente. Níveis mais altos são registrados no outono e inverno, ao redor das margens ou limites dos pastos; e na primavera, no interior dos bosques e florestas 65 .

Os gambás se alimentam mais extensivamente nos pastos durante o verão e outono, quando o crescimento do pasto atinge o máximo e o acasalamento dos 
gambás atinge o pico. Por isso, nestas estações do ano, os gambás estão em mais íntimo e mais freqüente contato com outros gambás e com o bovino. Essa época representa o período de incubação da infecção por M.bovis nos gambás, que no outono-inverno desenvolvem lesões tuberculosas visíveis. Os gambás que vivem dentro de bosques e florestas parecem ser infectados mais tardiamente no ano, por animais tuberculosos que freqüentam pastos e florestas, simultaneamente ${ }^{65}$. Os picos de nascimentos dos gambás ocorrem no outono (abril e maio) e primavera (setembro a novembro), sendo que nascimentos na primavera normalmente representam procriação dobrada ${ }^{216}$.

Alguns aspectos da história de vida dos gambás influenciam a freqüência da doença. Gambás de todas as idades e do mesmo sexo parecem igualmente prováveis de serem infectados, mas os machos são mais comumente infectados que as fêmeas, e significativamente, os jovens. Os níveis de infecção nos gambás refletem e, aparentemente, resultam de diferenças no comportamento. Os machos se alimentam em locais mais afastados, e gastam mais tempo nos pastos que as fêmeas; machos jovens dispersam-se por muitos quilômetros, enquanto fêmeas jovens permanecem nas áreas de suas tocas maternais ${ }^{65}$. Os gambás alimentam-se, principalmente, de frutas e gramíneas em pastagens arborizadas ${ }^{167}$.

Como os gambás regularmente inspecionam e farejam as áreas marcadas com fezes e urina de outros gambás, transgredindo os limites de sua área de habitação, a ingestão ou inalação de bacilos, parece provável. Os gambás são altamente susceptíveis ao M.bovis e, uma vez infectados, tornam-se muito infecciosos para outros animais ${ }^{65}$.

Os gambás recentemente infectados engordam significativamente menos que os não infectados, e muitos apresentam lesões avançadas e disseminadas, nos estágios finais da doença, reduzindo sua mobilidade e hábitos alimentares ${ }^{65}$.

As lesões nos gambás são mais comuns no trato respiratório (55 a $70 \%$ dos animais), entretanto, lesões em linfonodos superficiais têm sido registradas em acima de $50 \%$ dos gambás tuberculosos, sendo comum essas lesões supurarem intermitentemente ou continuamente, através de abcessos da pele ${ }^{65,105,173,199,216}$. As 
lesões no pulmão são muito extensas, envolvendo múltiplas lesões de miliares ou grandes abscessos, e proporcionam ampla oportunidade para excreções aéreas em muitos gambás infectados $65,149,173,199,216$. Lesões renais não são comumente encontradas, portanto, excreções urinárias não devem ser importantes na transmissão ${ }^{149}$.

Nos gambás, a tuberculose se manifesta como uma infecção progressiva e fulminante, largamente disseminada por todo o sistema linfático e vísceras, onde estão presentes grande número de bacilos que são excretados no meio ambiente por linfonodos supurados que formam abscessos, pelas fezes, saliva ou por exalação de exsudatos brônquicos e, ocasionalmente, pela urina ${ }^{65,173}$.

Texugos infectados parecem sobreviver por períodos mais longos do que os gambás, pois quando os gambás são detectados com sinais clínicos de tuberculose, muitos morrem em poucos meses ${ }^{149,216}$.

Os bovinos são os animais mais prováveis de se tornarem infectados, através do íntimo contato com gambás doentes terminais 105, 173, 199, 216. Acredita-se que alguns bovinos e, provavelmente, quase todas as espécies animais que se alimentam de carniça, como porcos selvagens, furões e outros, tornam-se infectados pelo contato com carcaças de gambás. Não existem evidências de que a contaminação dos pastos, das tocas e outras áreas frequientadas por gambás, seja responsável por um aumento significante da transmissão da doença entre gambás, ou entre gambás e outros animais ${ }^{199}$.

Em 1990, ocorreu tuberculose por M.bovis em 9 rebanhos de alces de criação em Alberta e 1 em Saskatchewan. Este foi o primeiro surto da doença em rebanhos comerciais de alces no Canadá. Uma revisão dos registros obtidos na fazenda de 1 dos 9 rebanhos infectados em Alberta, indicou que o mesmo era proveniente de alces da espécie Cervus elaphus, importados do Estados Unidos na primavera e verão de 1987, sendo que a fonte de infecção nos Estados Unidos foi confirmada posteriormente. A prevalência de lesões nesse rebanho canadense de 344 alces de criação foi alta. Inspeção em abatedouros detectou lesões micobacterianas em 134 $(39,8 \%)$ dos 337 alces recebidos para o abate. A prevalência das lesões aumentou 
com a idade dos animais, e a distribuição das mesmas sugeriu que a transmissão por aerossol foi o mais significante meio de propagação da doença entre o rebanho, pois ocorreram nos pulmões e linfonodos associados. Exames apenas dos linfonodos da cabeça e tórax, detectaram $118(88,1 \%)$ dos 134 alces com lesões ${ }^{216,280}$.

Em ambiente selvagem, os cervos são vistos como espécies marcadamente saudáveis, com poucas doenças naturais sérias, mas o contato com animais domésticos resultou em tuberculose bovina, que se transformou em endêmica em algumas populações de cervos selvagens na Nova Zelândia, Irlanda, Reino Unido, Hungria e América do Norte ${ }^{216}$.

A tuberculose por M.bovis nos cervos, freqüentemente é transmitida por meio da fêmea infectada para o filhote, mas pode também ser propagada horizontalmente entre fêmeas prenhes no final da gestação, de fêmeas para machos na época do cio, ou entre rebanhos de cervos que são mantidos em íntimo contato. Os animais jovens são particularmente susceptíveis à infecção e podem abrigar grande número de bacilos sem qualquer evidência patológica da doença, ou reatividade diagnostica típica de tuberculose ${ }^{134,173}$.

A expansão da criação de cervos em fazendas facilitou a circulação de animais entre elas e entre países, favorecendo a propagação da doença. A compra de animais infectados foi implicada em muitos surtos epidêmicos de tuberculose por M.bovis, em cervos. O confinamento de animais, principalmente durante o inverno, também facilitou a transmissão da infecção ${ }^{61}$.

Na Nova Zelândia, a significância epidemiológica da infecção por M.bovis em cervos está associada com seu hábito itinerante. Existem evidências de que eles podem agir como um vetor para a tuberculose, contraindo a doença durante seus movimentos em áreas ocupadas por gambás infectados e mais tarde espalhando a doença para grupos de gambás não infectados, principalmente nos locais onde a prevalência da doença no bovino é baixa. $\mathrm{O}$ hábito de caçadores eviscerarem cervos em bosques e abandonarem as carcaças que mereciam condenação exacerba este problema ${ }^{199,216}$. 
A infecção por M.bovis foi registrada em consignações de cervos da raça “red", importados pelo Reino Unido e provenientes do leste da Europa. Em 1985, o M.bovis foi isolado em 21 cervos de criação dessa raça, importados da Grã- Bretanha para a Hungria ${ }^{61,216}$. A infecção por M.bovis entre cervos da raça "roe" e texugos foi registrada na Suíça, onde o exame post mortem diagnosticou a tuberculose em 11 $(1,2 \%)$ de 892 cervos dessa raça, e em $5(18,5 \%)$ de 27 texugos ${ }^{25,61,216}$. Neste caso, foi sugerido que os texugos haviam sido infectados ao consumirem carcaças de cervos tuberculosos 25,61 .

Em 1991, a doença foi identificada em um rebanho de cervos de criação da raça "fallow" e espécie Dama dama na Suécia e nos 3 anos seguintes, outros 9 rebanhos infectados foram identificados. Investigações posteriores revelaram que todos os cervos infectados haviam tido contato, ou pertenciam a um grupo de 168 cervos da mesma raça e espécie, que haviam sido importados do Reino Unido em $1987^{40,216}$. É provável que a infecção tenha ocorrido durante o transporte, a quarentena e a subsequente distribuição dentro do país ${ }^{40}$.

Em 1992, um cervo cativo macho, de 3 anos de idade, da raça "sika" e pertencente a um pequeno rebanho de um proprietário particular em Illinois, Estados Unidos, apresentou infecção por M.bovis. O proprietário relatou que a cada ano morriam um ou dois cervos com progressivos sintomas respiratórios, mas que exames post mortem não haviam sido realizados. Em vista disso, o proprietário teve que eliminar todos os cervos da fazenda e outros animais que haviam tido contato com eles. Assim, 2 cervos e 4 gatos foram mortos e submetidos ao exame post mortem. Os 2 cervos também estavam infectados por M.bovis e 1 dos gatos apresentava lesões características nos linfonodos mesentéricos e intestino, mas não foi possível o isolamento do M.bovis. Acreditou-se que a transmissão entre os cervos e dos cervos para o gato ocorreu pela via aérea, devido às extensas lesões nos pulmões desses animais, e pelo íntimo contato que havia entre eles ${ }^{194}$.

A transmissão do M.bovis em macacos pode ocorrer via aerossol ou pela ingestão de alimento e água contaminados com urina, material fecal ou exsudatos de animais doentes e que contenham o bacilo da tuberculose. Fômites, como 
termômetros, gaiolas e recipientes usados para comida e água, podem ser fontes de infecção do M.bovis ${ }^{261}$.

A tuberculose por M.bovis tem sido raramente observada em macacos que vivem em estado selvagem. Há, entretanto, dois relatos de tuberculose em babuínos selvagens, no Kenya, África, nos quais se concluiu que a infecção foi contraída de outros animais que se alimentavam dos restos de vacas infectadas por M.bovis em um matadouro de uma aldeia, uma vez que, a transferência direta da infecção babuínopara-babuíno parece ser mínima ou inexistente ${ }^{216}$.

Um surto epidêmico de tuberculose em primatas não humanos devido a infecção pelo M.bovis foi relatado no zoológico de Dublin, na Irlanda. Investigações epidemiológicas detalhadas não identificaram a fonte de infecção, entretanto, um texugo foi encontrado moribundo na margem da estrada e trazido ao zoológico por um motorista, 11 semanas antes da morte do primeiro animal ${ }^{216}$.

A transmissão da infecção por M.bovis entre suínos ou de suínos para outros animais, não é considerada epidemiologicamente significante, pois lesões em porcinos invariavelmente permanecem localizadas, e porcos são usualmente abatidos precocemente ${ }^{181,199,216}$. Quando a transmissão ocorre entre os suínos, geralmente é consequiência de confinamento e das condições gerais de higiene das pocilgas ${ }^{245}$.

Apesar de existirem poucas evidências da transmissão da doença entre suínos, em 1964 a infecção por M.bovis foi registrada em 80 (54\%) das 149 lesões tuberculosas provenientes de um total de 260 suínos selvagens, necropsiados no Território Norte Australiano. A relativamente alta prevalência da infecção na população de suínos selvagens foi atribuída ao fato de que eles viviam em íntima associação com búfalos de pântano, os quais constituíam um reservatório e fonte de infecção por M.bovis. No final de cada estação seca, centenas de búfalos mais velhos morrem, tornando-se alimento e uma fonte potencial da infecção por M.bovis para suínos, que comem suas carcaças ${ }^{199,216}$.

Em um estudo de 1981, Corner e col. encontraram lesões no tórax e abdômen em 21 dos 61 (34\%) suínos tuberculosos submetidos à necropsia, ocorrendo o 
envolvimento do linfonodo submandibular em $85 \%$ dos casos. Concluíram que os suínos do Território Norte Australiano, eram quase certamente hospedeiros terminais e que raramente transmitiriam a infecção para outras espécies, mas que a transmissão para bovino ou búfalo poderia ocorrer, se esses animais farejassem ou comessem carcaças de porcos infectados, especialmente daqueles que morreram com lesões generalizadas ${ }^{186,199,216 .}$

Em 1992, foi estudada a prevalência da infecção por M.bovis na população de suínos selvagens de 5 áreas do Território Norte Australiano. Um total de 790 suínos foram necropsiados, e 49 (6.2\%) apresentaram lesões macroscópicas semelhantes à tuberculose. Um suíno macho, de 36 meses de idade, tinha um granuloma micobacteriano em um linfonodo submandibular, mas apenas $2(0.25 \%)$ suínos (sendo 1 macho e uma fêmea), de 34 e 48 meses de idade, respectivamente, apresentaram lesões macroscópicas em linfonodos submandibulares que foram positivas na cultura para M.bovis ${ }^{186}$.

A prevalência de 6,2\% de lesões macroscópicas semelhantes a tuberculose, aumentava com a idade do animal e era muito menor que os $47,7 \%$ registrados por Corner e col., no período de 1973-76. A prevalência da infecção por M.bovis de $0,25 \%$, representou também uma grande redução na incidência da doença, em comparação aos $19 \%$ encontrados 16 anos antes, nas mesmas áreas ${ }^{186}$.

Após este estudo ser concluído em suínos, a infecção por M.bovis foi confirmada nos búfalos da região, suspeitos de terem sido a fonte de infecção para os porcos. Os resultados deste trabalho demonstraram que a infecção por M.bovis na população de suínos selvagens, não tem significância para a erradicação da tuberculose em rebanhos de búfalos e bovinos ${ }^{186}$.

Em 1991, 78 (31\%) de 251 suínos selvagens na Nova Zelândia foram encontrados com lesões tuberculosas no exame post mortem, e concluiu-se que a infecção tinha possivelmente se propagado entre suínos, pela via respiratória ${ }^{199,} 216$. Neste mesmo ano, suínos selvagens foram implicados na transmissão da tuberculose por M.bovis para a população de cervos nativos, na ilha Havaiana de Molakai ${ }^{61}$. 
Como a abrangência de hospedeiros do M.bovis é muito ampla, isto implica em que a transmissão da infecção por um gato infectado pode ocorrer, se ele estiver abrigando micobactérias na saliva, urina, fezes e abcessos infectados na pele. Outros animais de estimação, quando em contato com gatos infectados, podem adquirir a infecção ${ }^{38,287}$.

É baixo o nível de infecção por M.bovis em gatos selvagens, e os limitados estudos disponíveis, sugerem que a infecção é adquirida principalmente pela predação e consumo de carcaças de outras espécies animais afetadas. A transmissão entre os gatos pode ocorrer através de brigas entre os machos e atividades sexuais ${ }^{149}$.

A tuberculose por M.bovis não tem sido registrada em gatos ou gambás na Austrália, mas Isaac e col. (1983) ${ }^{151}$ descreveram um surto epidêmico entre gatos, gambás na Universidade Monash, em Victoria ${ }^{151}$.

Um gato de aproximadamente 5 meses de idade, foi o caso índice deste surto. Ele era um dos 9 gatos que haviam sido transferidos de um biotério central para o biotério de um departamento da universidade. Dezessete dias depois, uma lesão submandibular exsudativa, de $5 \mathrm{~cm}$ de diâmetro, foi observada no animal. $\mathrm{O}$ gato morreu após 10 dias, e o M.bovis foi isolado do material purulento da lesão ${ }^{151}$.

Outro gato, de aproximadamente 6 meses de idade, apresentou problemas respiratórios, 6 semanas após a lesão do gato índice, morrendo 8 dias depois com lesões miliares nos pulmões e alguns nódulos no baço, observadas na autópsia. $\mathrm{O}$ M.bovis também foi isolado na cultura ${ }^{151}$.

Dez dias após o segundo caso, morreu um $3^{\circ}$ gato, cuja autópsia revelou lesões pulmonares com um grande número de bacilos álcool-ácido resistentes, mas não foi realizada a cultura. Exatamente 3 semanas após a autópsia desse último gato, 2 gambás mantidos na mesma sala com os gatos, foram mortos e examinados. Em 1 deles, o M.bovis foi isolado das recentes lesões nos pulmões e fígado. Ao mesmo tempo, outro gato foi autopsiado, e o M.bovis isolado. Após 2 semanas, outros 2 gatos apresentaram granulomas tuberculosos em tecidos e linfonodos, mas o M.bovis não foi isolado na cultura ${ }^{151}$. 
Concluiu-se que o gato índice havia sido infectado pela ingestão de carne contaminada, obtida de um açougue que forneceu carne fresca, semanalmente, para o biotério central, durante 6 anos; e que alguns dos outros casos foram infectados pela inalação do bacilo da tuberculose, que vertia da lesão purulenta do caso índice ${ }^{151}$.

No período de 1974 a 1986, o M.bovis foi diagnosticado em 57 gatos no Laboratório de Saúde Animal da Nova Zelândia. Lesões tuberculosas na pele, foram observadas em 33 (58\%) dos gatos. Com exceção de 6, esses gatos vinham de áreas rurais e suburbanas da Nova Zelândia, onde o M.bovis também estava presente em animais selvagens, especialmente em gambás da raça "brush-tailed" ${ }^{216}$. A maior prevalência de lesões localizadas e infectadas na pele dos gatos foi resultante de ferimentos por dentadas de gambás tuberculosos ${ }^{287}$.

Um caso de infecção por M.bovis em uma lebre de vida livre, da raça "brown" e espécie Lepus europaeus occidentalis, foi registrado na Nova Zelândia. A lebre, uma das 6 capturadas em armadilhas durante um levantamento sobre gambás tuberculosos, foi encontrada com evidências de infecção por M.bovis. Este foi o primeiro registro de tuberculose por M.bovis ocorrida naturalmente em lebre dessa raça. A prevalência de tuberculose nos gambás pesquisados foi excepcionalmente alta (cerca de 60\%) com mais de 30\% apresentando grandes lesões supuradas em regiões da pele ${ }^{216}$.

Em junho de 1991, em um zoológico de New Orleans, nos Estados Unidos, morreu um rinoceronte macho, de 29 anos de idade, da espécie Ceratotherium simum simum, e cuja necropsia revelou uma severa pneumonia granulomatosa por M.bovis ${ }^{91,256}$. Em outubro de 1991, um macaco macho, de 2 anos de idade, da espécie Colobus guereza caudatus, morreu de tuberculose pulmonar por M.bovis, após 2 meses de isolamento e tratamento. Em dezembro de 1991 outro macaco, também macho, de 6 anos de idade e da mesma espécie, morreu de tuberculose generalizada por M.bovis, após 3 meses de isolamento e tratamento ${ }^{256}$.

Foram realizados testes de DNA para a comparação das 3 cepas de M.bovis dos animais mortos, e os resultados indicaram que os 3 isolamentos eram geneticamente similares, e que uma única cepa micobacteriana foi, provavelmente, 
responsável pela infecção nos 3 animais ${ }^{256}$.

O rinoceronte havia sido importado da África 15 anos antes, e acreditou-se que ele havia sido infectado nessa época, na vida selvagem, e em 1991 apresentou uma reativação tardia da tuberculose. Os autores sugeriram que os 2 macacos haviam sido infectados pelo rinoceronte, mas como eles viviam em cativeiros separados por uma distância de aproximadamente 15 metros, a única explicação encontrada para a transmissão do M.bovis entre eles foi, provavelmente, via aerolização do bacilo, durante a lavagem da área pertencente aos rinocerontes com mangueiras de alta pressão, ou através de ventiladores de teto, que poderiam propagar as gotículas contaminadas, expelidas pelo animal doente ${ }^{256}$.

Em um estudo realizado em uma fazenda de Dorset, Inglaterra, no período de 1970 a 1976, o M.bovis foi isolado dos linfonodos de 2 (2,2\%) dos 90 ratos da espécie Rattus norvegicus, e de 1 (14,3\%) das 7 raposas da espécie Vulpes vulpes, durante um surto epidêmico de tuberculose no bovino e texugos. No exame post mortem não foram encontradas lesões tuberculosas, mas concluiu-se que os texugos não eram as únicas espécies mamíferas selvagens, que agiam como reservatórios do M.bovis nesta área ${ }^{125,181}$.

Os ratos, possivelmente se tornaram infectados pela ingestão de grãos de milho existentes nas fezes de texugos doentes, nesta fazenda, ou por se alimentarem de carcaças de texugos tuberculosos; além de utilizarem, freqüentemente, os setts dos texugos ${ }^{181}$.

As raposas também habitam os setts abandonados pelos texugos com muita freqüência, estabelecendo uma relação comensal com esses animais, e poderiam ter sido infectadas ao se alimentarem de carcaças de texugos tuberculosos, uma vez que são consumidoras oportunistas de carniças ${ }^{181}$.

\subsection{8- RESERVATÓRIOS ANIMAIS PARA HUMANOS}

Seres humanos adquirem a infecção pelo M.bovis, especialmente de bovinos, 
mas também de outros animais utilizados para a produção de carne e leite, incluindo cabras, cervos, búfalos, carneiros e camelos ${ }^{196,263}$.

Entre os animais domésticos, deve-se dar particular ênfase ao gato, sensível à tuberculose humana (gatos de companhia e de raça) e bovina (gatos criados em fazendas), podendo apresentar tuberculose pulmonar pela inalação de aerossóis, e digestiva adquirida principalmente pela ingestão de leite contaminado fornecido nos estábulos $131,201$.

A forma intestinal da doença é mais freqüente que a doença pulmonar em gatos, e por isso a disseminação da micobactéria pode ocorrer pelas fezes desses animais. A tuberculose em animais de companhia tem sido relacionada com a ocorrência da doença em populações humanas e bovinas. A transmissão entre gatos e seres humanos e gatos e bovinos, tem sido documentada. O tratamento da tuberculose em animais domésticos de estimação, não é recomendado porque envolve riscos para a saúde pública ${ }^{131,174,194}$.

O perigo que a ocorrência da tuberculose em animais cativos em zoológicos e parques animais, representa para a saúde pública, é enfatizado pelo encontro de lesões pulmonares em macacos infectados, babuínos, oryxes e kudus. A propagação do M.tuberculosis e M.bovis através de aerossóis, é considerada a rota mais comum da transmissão dessa infecção, e animais infectados são uma fonte potencial para a doença no homem ${ }^{260}$.

Na Nova Zelândia, existem agora 21 áreas onde a tuberculose bovina é endêmica, e todos os casos de infecção humana são provenientes de áreas onde o M.bovis é suspeito de ser endêmico no bovino, cervo ou animais selvagens, sugerindo que os animais selvagens infectados com M.bovis podem ser a fonte de infecção para os humanos ${ }^{45}$. Têm ocorrido infecções por M.bovis em pessoas que estão em contato com cervídeos e cabras, animais que desenvolvem uma séria forma de tuberculose, associadas ao novo sistema intensivo de manejo, que consiste no confinamento de animais livres. A manutenção de espécies exóticas e selvagens de animais em cativeiros, particularmente em zoológicos e parques, favorece a propagação do M.bovis e a possibilidade de transmissão aos zeladores e guardas 
locais ${ }^{196}$.

No Japão, existe a preocupação sobre a ocorrência de tuberculose no bovino, suíno e em cervos, e pesquisas realizadas sugeriram a possível transmissão da tuberculose de animais cativos para o homem. A criação de cervos, como animais domésticos, tem se tornado popular no Japão, e o número de fazendas de criadores desses animais, têm aumentado consideravelmente ${ }^{152}$.

Em 1980, ocorreu infecção por M.bovis em um rebanho de alces em Dakota, Estados Unidos, e 3 pessoas em contato com o rebanho converteram para positivo o teste tuberculínico. O M.bovis pode ter sido transmitido por aerossóis contendo a micobactéria, através da tosse de alces infectados, ou pela propagação de partículas infecciosas durante a necropsia dos animais ${ }^{108}$.

Em 1990, houve um surto de infecção por M. bovis no Canadá, originário de alces de criação (Cervus elaphus var canadensis, conhecido como "red deer" na Europa). O isolamento do M.bovis em um alce domesticado em Alberta permitiu às autoridades médicas o acompanhamento dos contatos humanos. Um veterinário apresentou tuberculose pulmonar após examinar um alce tuberculoso, e vários trabalhadores tornaram-se tuberculina-positivos ao serem expostos à carcaças de alces tuberculosos 108, 179, 216, 259, 280. Entre os contatos, 81 (21\%) de 394, eram tuberculina-positivos, sendo que a taxa estimada de positividade para o teste da tuberculina para humanos em Alberta, era de $10 \%$ 108, 179, 216 . Na Inglaterra, Dinamarca, Havaí e Estados Unidos, também têm sido encontrados alces infectados por esta micobactéria ${ }^{92,107,108,148,259,261 .}$

Existem relatos da transmissão da tuberculose por M.bovis para humanos, proveniente de gatos e cachorros infectados por carne e leite de animais doentes $^{163,201}$.

Na Austrália, Isaac e col. (1983) ${ }^{151}$ descreveram um surto epidêmico entre gatos, gambás e, provavelmente, um pesquisador na Universidade Monash, em Victoria, que havia tido íntimo contato com os animais infectados, apresentando uma reação de Mantoux (tuberculina) muito forte, e por essa razão, um tratamento 
profilático foi iniciado ${ }^{151}$.

Em 1988, no sul da Austrália, um treinador de focas que trabalhava em um parque aquático desde 1985, desenvolveu tuberculose pulmonar causada por M.bovis, transmitida por uma das 3 focas que haviam morrido nesse parque em 1986 devido à infecção por este agente. Após a morte dessas focas, 10 das 11 remanescentes no parque foram testadas com tuberculina bovina e 7 focas estavam positivas; consequentemente, toda a colônia desses animais foi destruída. Esta foi a primeira vez que o M.bovis foi observado nestes animais, e também a primeira que tal infecção foi documentada como transmitida de focas para humanos ${ }^{263,265}$.

Um surto de infecção humana devida à transmissão aerógena de M.bovis, ocorreu em 1991 em um zoológico de New Orleans, nos Estados Unidos, proveniente de um rinoceronte que havia morrido de uma severa pneumonia granulomatosa naquele ano, e em cujos granulomas foi isolado o M.bovis. Entre as 24 pessoas expostas ao animal tuberculoso, 7 (29\%) demonstraram conversão à tuberculina, mas nenhum apresentou doença clínica. Das 7 pessoas tuberculina-positivos, 6 eram zeladores do zoológico e responsáveis, diariamente, pela alimentação e limpeza dos rinocerontes, e 1 pessoa era um administrador que havia auxiliado na necropsia. Todos foram submetidos à quimioprofilaxia com isoniazida $91,179,256$.

O grande número de zeladores tuberculina-positivos indicou um alto grau de exposição. Acredita-se que durante os 2 meses nos quais o rinoceronte apresentou doença clínica, o animal tenha excretado um grande número de bacilos na saliva, na secreção nasal mucopurulenta bilateral e, provavelmente, nas fezes e urina, expondo os zeladores ao M.bovis durante, aproximadamente, 60 dias. Este surto exemplifica a importância da transmissão por aerossol do M.bovis, para animais e humanos ${ }^{91,256}$.

\subsection{9- RESERVATÓRIOS ANIMAIS PARA BOVINOS}

A tuberculose bovina é rara na vida selvagem, exceto quando esses animais são expostos a bovinos e pessoas infectadas. A importância de cada reservatório animal na transmissão da doença ao bovino depende do grau de contato entre eles e 
da quantidade de bacilos da tuberculose que são excretados por essas espécies animais de vida livre ${ }^{228}$.

Entre a população de animais selvagens, os texugos são os mais importantes reservatórios da infecção por M.bovis. ${ }^{25,26,63,64,68,148}$. O grau de contato direto ou indireto, entre texugos infectados e bovinos, é a chave para o processo da transmissão ${ }^{47}$.

A infecção por M.bovis em texugos, na Inglaterra e Irlanda, confere um relativamente baixo, porém real, risco de infecção para o gado ${ }^{31,58,210,216}$. Quando infectados, os texugos podem desenvolver sinais externos da doença, na forma de ferimentos por dentadas infectados; e uma alta proporção deles, apresenta doença renal. Eles urinam e defecam nos pastos, expondo o gado a uma alta concentração de material infeccioso ${ }^{62,120,148,278}$. Bovinos e texugos infectados, podem coexistir por longos períodos sem que a doença seja necessariamente transmitida ao gado. Há evidências de que o risco de transmissão possa ser sazonal, coincidindo com a época de maior atividade dos texugos, na primavera 47, 149, 210, 216 . Esta sazonalidade na transmissão, possivelmente seja resultante de texugos infectados, especialmente fêmeas lactantes, desenvolvendo doença ativa depois do estressante período de inverno $58,210,216$.

Em algumas regiões da Inglaterra, a população de texugos é muito grande, com 30 a 40 texugos por $\mathrm{km}^{2}$, que além do risco de estarem infectados pelo M.bovis, causam problemas a certos tipos de agricultura e provocam acidentes com maquinários agrícolas, ao correrem pelos campos em busca de seus setts ${ }^{109}$.

Os texugos são saqueadores, pois não estocam alimentos. Durante a noite percorrem grandes distâncias (em média $1 \mathrm{~km}$ ), sendo que os machos se dispersam mais que as fêmeas; por isso, em algumas ocasiões são encontrados nos estábulos das fazendas, alimentando-se de forragens e outros alimentos pertencentes ao gado ${ }^{149}$, 203. Em mais de $6 \%$ dos texugos, ocorre o desgaste, quebra ou perda dos dentes, além da formação de abscessos que facilitam a entrada de alimento contaminado na corrente sanguiínea ${ }^{146}$. 
A transmissão da infecção de texugos para o bovino é considerada como indireta, por contato com material infeccioso excretado. Acredita-se que a transmissão aérea indireta da infecção ocorre, quando o gado curiosamente cheira ou fareja pasto ou feno fortemente contaminados com urina fresca ou escarro de texugos tuberculosos $31,216,285$.

Existe provavelmente um contato direto muito limitado entre as duas espécies de hospedeiros, uma vez que os texugos, sempre que possível, esquivam-se dos bovinos. Entretanto, o gado pode ser diretamente exposto à infecção quando cheiram, farejam ou lambem carcaças infectadas de um texugo tuberculoso em estágio terminal da doença, ou morto, durante um procedimento investigatório. Ou ainda, quando texugos, nos estágios avançados da doença, apresentam comportamentos aberrantes e passam a habitar os estábulos ou outros locais pertencentes ao gado, compartilhando alimentos e recursos hídricos 31, 100, 120, 180, 199, 203, 210, 216, 278.

Existem registros de mudanças no comportamento de texugos com avançadas lesões tuberculosas. Em um dos casos ocorridos, um texugo doente foi encontrado em um chiqueiro de porcos. Outro seguia pessoas durante o dia, sendo que o ser humano é um inimigo natural dos texugos. Um texugo foi morto durante o dia ao se aproximar de um galinheiro, e outro, severamente afetado, foi encontrado no jardim de uma residência e posteriormente, em uma estrebaria. Estes casos sugeriram, que texugos com tuberculose avançada podem deixar seus setts em busca de alimentos, ou podem ser rejeitados pelos ocupantes dos setts e por isso, perambulam de fazenda para fazenda para viverem sozinhos em estábulos, entre o gado. Cada animal constitui uma ameaça, e a tarefa de identificação dos setts contaminados por amostras de fezes é dificultada, porque eles podem percorrer distâncias consideráveis de seus setts de origem ${ }^{203}$.

Mesmo assim, a exposição indireta é, provavelmente, a principal rota de transmissão, já que os texugos tuberculosos excretam um grande número de bacilos nos estágios terminais da doença. Escarro, urina, fezes e exudatos purulentos de linfonodos que se romperam, além de abscessos ou ferimentos por dentadas na pele, podem ser implicados na contaminação dos pastos, água ou alimentos utilizados 
pelos bovinos $62,100,120,125,149,180,203,210$.

Os texugos têm um sistema de latrinas no qual todos os membros de um grupo usam as mesmas áreas, bem definidas, para urinarem e defecarem ${ }^{148}$. Eles escavam latrinas rasas, defecam e as deixam cobertas. Essas latrinas estão localizadas, preferencialmente, em solo macio perto dos setts, ou ao longo das pegadas deixadas pelos animais pertencentes aos setts. Podem também ser encontradas sob um matagal ou sob plantações que formam cercas vivas ao redor dos pastos e, ocasionalmente, nos pastos ${ }^{199}$. Se acontecer dessas áreas serem o local de pastagem dos bovinos, esse gado estará exposto a uma alta concentração de material infeccioso ${ }^{148}$.

O gado pasta, preferencialmente, ao redor dos limites dos campos, aumentando a possibilidade de contato com urina de texugos nos pontos de cruzamento, e com urina e fezes nas latrinas; uma vez que o número delas se correlaciona com a quantidade de fronteiras dos campos em certas áreas. Texugos também concentram suas atividades de alimentação perto dessas fronteiras, e o escarro ou pus de feridas deixadas no pasto por texugos em busca de alimentos, são outras fontes potenciais de infecção $47,125,149,216,278$.

Durante o dia, os texugos normalmente permanecem sob a terra em seus setts. Possuem hábitos noturnos, mas, nos meses de verão, quando as noites são curtas, eles saem no final da tarde e retornam aos seus setts bem depois do amanhecer. Minhocas são o item principal na dieta alimentar dos texugos na Irlanda e Grã-Bretanha, e são encontradas principalmente nos pastos utilizados pelos bovinos 100, 125, 149, 180, 216 .

Outros itens da dieta dos texugos consistem de besouros, vespas e outros insetos. Esporadicamente, comem arganaz, jovens coelhos, e outros pequenos mamíferos. Sua dieta vegetal inclui raízes, bulbos (cebolas), vegetais, frutas, nozes e grãos $^{203}$.

No período de junho de 1991 a maio de 1992, foi realizado um estudo no sudoeste da Inglaterra, para a observação do comportamento urinário de 42 texugos. Das 125 urinações registradas, $24 \%$ foram em latrinas na floresta, $28 \%$ em latrinas 
nos pastos, $28 \%$ em pastagens distantes das latrinas e dos setts, e $20 \%$ em florestas longe das latrinas e dos setts ${ }^{278}$.

Nesses lugares, deve haver variações locais consideráveis na prevalência da infecção por M.bovis na população de texugos, e apesar da discordância de muitos pesquisadores, parece que existe uma relação direta entre prevalência de infecção no gado e densidade populacional de texugos. Apesar de que altas prevalências no gado foram encontradas em áreas de baixa densidade de texugos, e viceversa $^{47,58,180,210,216,285}$. Dados de um estudo na Grã-Bretanha, sugerem que deve haver um ciclo de prevalência da doença nos texugos, com uma periodicidade de 5 a 7 anos; mas não há ainda conhecimento das dinâmicas espaciais da doença $^{47,58,180,199,210,216,285}$.

Apesar de bovinos geralmente evitarem o contato com urina e fezes de texugos depositadas nos pastos, eles tem uma aversão menos pronunciada pela urina. Observou-se que o gado consome pastagem contaminada pela urina de texugo após 8 a 24 horas de deposição, mas esquivam-se de pastos contaminados com fezes desses animais, as quais ocorrem, mais freqüentemente, em torno das latrinas $^{31,47,149,199,216,278}$.

Estima-se que o número de bacilos presentes nas excreções de texugos tuberculosos é da ordem de 300.000 por ml na urina, quando os rins estão afetados, e 200.000 por ml no pus bronquial ${ }^{31,47,216,278}$. A importância dessas excreções na transmissão da infecção ao gado depende do número de bacilos viáveis aos quais os bovinos estão expostos, mas acredita-se que a urina representa um risco maior $^{31,62,120,149,199,216,278}$. Entretanto, apesar do número de bacilos nas fezes ser menor, estudos realizados na Nova Zelândia em 1996, sugeriram que todo o gado positivo para M.bovis poderia ser considerado infectado via fezes de texugos ${ }^{146}$.

A biomassa das minhocas nos pastos pode variar de $1.000-4.000 \mathrm{~kg}$ por hectare (100 metros quadrados), havendo, portanto, uma abundância de alimento disponível nos bons pastos. Nas noites de moderada umidade, as condições alimentares são ideais com as minhocas lixiviando a superfície do solo ${ }^{216}$. O período de fevereiro a maio é o mais importante, porque nesta época as fêmeas de texugos, 
em particular, precisam se alimentar bem e rapidamente, a fim de amamentarem e não se ausentarem de seus filhotes por tempo maior do que o necessário ${ }^{58,216}$. Os texugos passam muito tempo durante a noite alimentando-se de minhocas nos pastos, e em um relativamente curto período de tempo, grandes volumes de urina podem ser excretados ${ }^{180,216}$.

Durante o ano de 1973, houve um aumento de 9,25\% na taxa de bovinos reatores à tuberculina na região de Cork, na Irlanda. Dos 20 rebanhos (1.048 bovinos) testados neste surto epidêmico, 12 apresentaram reações positivas, resultando na remoção de 97 animais, dos quais 40 possuíam lesões visíveis de tuberculose no exame post mortem. Havia a suspeita de que os animais selvagens presentes na região eram a possível fonte de infecção, por isso, os veterinários locais examinaram 12 espécimes que consistiram de 7 raposas e 5 texugos, sendo que 1 texugo apresentou lesões visíveis de tuberculose nos linfonodos mesentéricos e mediastínicos anteriores, demonstrando os riscos que os proprietários dos rebanhos corriam, ao abrigarem animais selvagens em suas fazendas ${ }^{211}$.

Em 1974, muitos dos novos rebanhos, previamente não afetados, tornaram-se reatores à tuberculina, aumentando a suspeita do envolvimento de animais selvagens $^{211}$. Em 1996, a proporção de surtos de tuberculose por M.bovis no bovino, associados com a presença de animais selvagens infectados, principalmente texugos, era de aproximadamente 2,5\% na Irlanda do Norte e variava de 14 a $27 \%$ na República da Irlanda ${ }^{149}$.

Lesões tuberculosas também são encontradas em texugos selvagens em Gloucestershire, na Inglaterra. Entre abril de 1971 e abril de 1973 foram examinadas carcaças e fezes desses animais. O M.bovis foi isolado de 36 (21,8\%) das 165 carcaças analisadas, e de $12(10,7 \%)$ das 112 amostras de fezes, provenientes de 23 locais diferentes 167,203 . Dezessete desses locais eram fazendas de rebanhos de bovinos, nas quais a tuberculose era um problema persistente. O possível papel dos texugos como reservatórios da tuberculose em Gloucestershire foi discutido, e a evidência de uma associação entre a tuberculose nos texugos e a doença no gado, foi baseada na alta taxa de infecção dos texugos examinados, que foi de $22 \%$; na 
proximidade de texugos infectados e bovinos; na oportunidade de propagação da doença dos texugos para o gado, uma vez que esses animais eram comuns em quase todas as fazendas localizadas no sudoeste do município; e no fato de que, a maioria dos rebanhos bovinos tuberculosos habitava a mesma região que possuía a maior população de texugos, dentro do município ${ }^{203}$.

A significância da proximidade desses rebanhos com os locais dos texugos infectados tornou-se aparente quando surtos ocorreram, principalmente em animais jovens (com menos de 3 anos de idade) do rebanho, que pastavam preferencialmente nas regiões próximas ao território dos texugos. Em um dos setts estudados, foram capturados 6 texugos infectados, sendo que 5 (83\%) deles apresentavam lesões abertas; e em novembro de 1971, 3 bovinos jovens que pastavam próximos ao local, estavam infectados por M.bovis. Posteriormente a esse caso, uma vaca de um rebanho vizinho, e que pastava junto a este sett, também apresentou tuberculose devida ao M.bovis ${ }^{203}$.

O maior surto epidêmico de tuberculose em bovinos na Inglaterra, ocorreu em uma fazenda em Dorset, no período de 1970 a 1976, quando 626 animais foram abatidos. Nenhuma fonte de infecção foi encontrada até 1974, quando texugos infectados com M.bovis foram descobertos na região. Houve dois picos da infecção, nos anos de 1970 e 1974, quando $29,8 \%$ e $27,3 \%$ dos bovinos, respectivamente, reagiram ao teste da tuberculina ${ }^{285}$.

Na região foram encontrados 240 setts de texugos. Em um estudo preliminar, $4(28,6 \%)$ das 14 amostras de fezes desses animais continham M.bovis e $2(40,0 \%)$ de 5 texugos, tinham lesões tuberculosas. A facilidade com a qual a tuberculose foi descoberta na população de texugos indicou que havia uma alta prevalência de infecção e doença nesta população, posteriormente confirmada por outra amostragem, na qual $12(60,0 \%)$ de 20 animais estavam infectados por M.bovis ${ }^{180}$.

Dos 7.557 texugos mortos na Grã-Bretanha entre 1971 e 1983, na vizinhança imediata de fazendas de bovinos, nas quais havia ocorrido uma inexplicável perda de parte dos rebanhos, $13 \%$ estavam infectados com M.bovis ${ }^{216}$. 
Uma diminuição nos surtos de tuberculose em rebanhos durante seca de 197576 foi vinculada a uma segregação ecologicamente natural de texugos e bovinos, causada pela falta de minhocas no pasto, e o aumento do uso de bosques pelos texugos para se alimentarem de invertebrados mais disponíveis, obtidos entre as folhagens úmidas ${ }^{216}$. Em 1990, das 811 carcaças de texugos examinadas na Inglaterra, 156 (19\%) estavam infectadas com M.bovis ${ }^{148}$.

De acordo com o boletim anual do Ministério da Agricultura da Inglaterra, em 1990 haviam 104 rebanhos bovinos infectados no sudoeste da Inglaterra, local onde a maioria dos casos de tuberculose bovina do Reino Unido está concentrada ${ }^{100,268}$. Em 1989, estavam infectados 96 rebanhos em comparação com 72 em 1988. Deste surto de M.bovis em 104 rebanhos, comprovou-se que 80 rebanhos haviam adquirido a infecção de texugos, enquanto em apenas 1 dos 39 surtos ocorridos no resto da Inglaterra, País de Gales e Escócia, o texugo estava envolvido na transmissão da infecção ${ }^{268}$.

Em 1992, 588 rebanhos de bovinos foram detectados na Grã-Bretanha com evidências de infecção por M.bovis. Desse total, 353 eram do sudoeste da Inglaterra e em $144(40,8 \%)$ destes rebanhos, a infecção foi confirmada pelo encontro de lesões tuberculosas no exame post mortem, ou pela cultura para M.bovis. Como resultado, 1.028 texugos foram capturados e mortos nesta região, e 209 (20,3\%) animais estavam infectados por M.bovis após análises bacteriológicas e exames post mortem $^{63}$.

Em 1996, 316 novos rebanhos bovinos estavam tuberculosos, e havia evidências de que a doença estava se propagando da região sudoeste da Inglaterra para as regiões norte e leste ${ }^{147}$.

Até 1997, a tuberculose bovina continuava a ser o mais sério problema de saúde animal, principalmente em fazendas leiteiras da região sudoeste da Inglaterra. Por isso, é fundamental que pesquisas consigam estabelecer como os ciclos da infecção, entre e nas populações de bovinos e texugos, são mantidos ${ }^{146,147}$. Existe ainda, pouco conhecimento de como a tuberculose pode ser transmitida dos texugos para o gado ${ }^{100,278}$. Sabe-se apenas, devido a estudos recentes, que os texugos 
infectados natural ou experimentalmente agem como uma fonte de infecção para os bovinos ${ }^{199}$.

Suspeita-se que a transmissão do M.bovis de gambá para bovinos ocorre quando o gado investiga e fareja gambás doentes ou terminais que vagam pelos pastos, próximos ao seu habitat (que margeia os campos e florestas), ou suas carcaças infectadas 24, 105, 149, 199 . Estes animais gastam mais tempo nos pastos, e podem excretar grande número de bacilos pela via respiratória ou por meio de cavidades ou abscessos abertos ${ }^{149}$.

Nos gambás, as lesões tuberculosas são, ocasionalmente, abertas e, quando infectados, carregam uma grande quantidade de M.bovis em seu organismo, excretando o bacilo através da urina, fezes, exudatos brônquicos e feridas supuradas, o que os torna um reservatório auto-mantenedor da tuberculose e uma fonte contínua de infecção para o bovino e outros animais ${ }^{24,65,105,173,228}$. O seu controle reduz imediatamente a incidência de gado tuberculina-positivo na área ${ }^{24,65}$.

Existem boas razões para a suspeita de que gambás e texugos disseminam a doença para o gado, mas a prova definitiva é dificultada por dois motivos: a falta de sistemas discriminativos de tipificação de cepas e a dificuldade em observar essa transmissão, pelo fato de envolver animais selvagens ${ }^{68}$.

Entretanto, o papel dos gambás na manutenção da tuberculose em rebanhos de gado na Nova Zelândia, é completamente aceito atualmente. O comportamento alimentar, habitacional e de pilhagem dos gambás; sua densidade; o uso dos bosques e florestas; a interação com o bovino e outros animais; e a susceptibilidade ao M.bovis, contribuem para a provável manutenção, em longo prazo, dessa doença ${ }^{65}$.

Uma possível explicação para a persistência da doença na Nova Zelândia, após a aplicação de medidas de controle no gado e nos gambás, é que as cepas de M.bovis parecem ser particularmente mais virulentas, resultando em uma maior transmissibilidade e infectividade ${ }^{65}$.

Cervos selvagens também atuam como um potencial reservatório da infecção por M.bovis, mas eles têm uma menor prevalência de infecção e seus padrões 
comportamentais são muito diferentes dos texugos, particularmente o fato de não possuírem um sistema de latrinas ${ }^{148}$. Entretanto, em alguns cervos, a doença tem um curso agudo e produz lesões com tendência à formação de fístulas supurativas, que podem contaminar as áreas freqüentadas pelo bovino ${ }^{173}$.

Nos Estados Unidos, em 1934 foi reportado que uma cabra tuberculosa, aparentemente infectou um rebanho de bovinos ${ }^{216}$.

Também nos Estados Unidos, alces domesticados foram implicados na transmissão do M.bovis para 2 rebanhos de gado em Nebraska e para 2 rebanhos leiteiros em Nova York. Esta transmissão por alces apresenta um maior risco para o bovino americano do que a transmissão por animais selvagens, porque não existem leis federais para controlar o movimento interestadual de rebanhos desses animais. E também porque, aparentemente, o M.bovis está ausente da vida selvagem deste país, desde a sua erradicação em cervos selvagens da raça "axis" e suínos no Hawaí, durante o período de 1980 a $1985^{92}$.

A transmissão do M.bovis de suínos selvagens para o bovino, é considerada improvável, devido ao pequeno contato entre essas espécies animais, e à baixa prevalência de lesões pulmonares generalizadas nos porcos, que poderiam levar à excreção do bacilo infeccioso ${ }^{228}$. Entretanto, no período de 1964 a 1969, foram diagnosticados 14 casos de tuberculose por M.bovis em suínos selvagens, na Nova Zelândia, sendo que em uma fazenda, porcos selvagens foram suspeitos de causarem um surto de tuberculose no bovino ${ }^{105}$.

Durante um surto de infecção por M.bovis em bovinos, devem ser investigados cães e gatos que porventura habitem a fazenda e que sejam alimentados com leite cru e carnes, ou miúdos não cozidos ${ }^{131}$.

\section{6- TRATAMENTO}

Desde a descoberta do agente causal da tuberculose, passaram-se mais de 60 anos até que surgissem drogas realmente eficientes. Antígenos e extratos do corpo 
bacilar, soros, medicamentos como os sais de ouro e cobre, foram de resultados precaríssimos ou nulos ${ }^{236}$.

Atualmente, a tuberculose é uma doença ainda grave, porém curável em praticamente $100 \%$ dos casos novos, desde que obedecidos os princípios da moderna quimioterapia. A associação medicamentosa adequada e seu uso regular, por tempo suficiente, são os meios necessários para evitar a resistência e a persistência bacterianas ${ }^{193}$. No tratamento de tuberculose por M.bovis, deve ser considerado o fato de que essa micobactéria é naturalmente sensível às drogas antituberculosas, com exceção da pirazinamida ${ }^{1,74,154,249}$. O M.bovis é naturalmente resistente à pirazinamida, mas a resistência primária às drogas antituberculosas de $1^{\mathrm{a}}$ linha é rara, sendo que 2,8-10,0\% das cepas são resistentes à isoniazida, 0-1,4\% à rifampicina e nenhuma a ambos, simultaneamente ${ }^{249}$.

Até 1944 várias drogas foram testadas no tratamento da tuberculose, sem sucesso. Em 1944, Waksman, pela primeira vez, empregou a estreptomicina no tratamento da tuberculose, mudando o curso da doença, apesar de tê-la descoberto em $1940^{191,223}$. Depois disso, gradualmente, novas drogas foram incorporadas ao arsenal terapêutico: em 1947, o ácido para-aminosalicílico; em 1950, a isoniazida e, em 1969, a rifampicina ${ }^{111,191 .}$.

A combinação dos 3 medicamentos: estreptomicina, ácido paraaminosalicílico e isoniazida originou o $1^{\circ}$ esquema tríplice para o tratamento da tuberculose, uma vez que a administração individual de cada droga induzia o aparecimento de mutantes resistentes na fase inicial da terapêutica e a multiplicação de bacilos que haviam permanecido latentes nas lesões, após a interrupção do tratamento $111,223,236$.

Esse esquema exigia administração prolongada (cerca de 2 anos) e nem sempre lograva cura total. Foi quando surgiram as chamadas drogas de $2^{\mathrm{a}}$ linha: pirazinamida, cicloserina, capreomicina, etambutol, tissemicarbazona, etionamida e outras menores, utilizadas como preventivos de complicações operatórias ${ }^{111,223,236}$.

Em 1969, pesquisadores italianos descobriram um novo antibiótico, isolado a 
partir do Streptomyces mediterranei, denominado rifampicina, talvez o mais sensacional de todos os remédios da tuberculose, que deslocou a estreptomicina para droga auxiliar. Nascia assim o novo esquema tríplice: rifampicina, isoniazida e uma terceira droga de apoio, a pirazinamida ou o etambutol. Os resultados do novo esquema tríplice logo foram sentidos, permitindo encurtar o tratamento para 9 meses nos Estados Unidos e França, e até 6 meses, no Brasil 111, 223, 236.

De maneira genérica, as drogas antituberculosas interferem no sistema enzimático do bacilo ou bloqueiam a síntese de algum metabólito essencial para o seu crescimento. Assim, por exemplo, a isoniazida intervém no metabolismo de lipídios do germe e bloqueia certos ácidos aminados necessários ao equilíbrio das proteínas, freando a formação de DNA e RNA; a estreptomicina interfere na síntese de proteínas da carapaça microbiana e penetra nos ribossomos, ocupando o lugar das poliaminas que, em decorrência, não podem ligar-se ao RNA mensageiro; a rifampicina inibe a atividade da enzima RNA polimerase, unindo-se a esta e formando um composto sólido, estável e insolúvel, impedindo sua síntese ${ }^{236}$.

Por isso, a ação das drogas só é exercida se os bacilos estão ativos em multiplicação. Se os germes estão "hibernados", em estado quiescente, sem se multiplicar e, portanto, sem atividade metabólica, as drogas não têm como agir. Estes bacilos só podem ser destruídos pelas defesas imunitárias orgânicas ${ }^{236}$.

Pesquisas realizadas sobre a relação bacilo-medicamento evidenciaram que os bacilos da tuberculose possuem uma vida intracelular (proliferam-se no interior dos macrófagos) e outra extracelular (proliferam-se no meio que os rodeia) e também estabeleceram a existência de 3 diferentes tipos de população bacilar:

$1^{\circ}$-bacilos de multiplicação rápida, que vivem no cáseo liqüefeito das paredes cavitárias,

$2^{\circ}$-bacilos de multiplicação moderada, em menor número que o $1^{\circ}$, e se encontram no interior dos macrófagos,

$3^{\circ}$-bacilos de multiplicação lenta e intermitente, que habitam as massas caseosas sólidas. 
Assim, as drogas também podem ser classificadas de acordo com sua atividade em relação às diferentes propriedades reprodutoras do bacilo. As que possuem atividade contra os bacilos do $1^{\circ}$ grupo são a estreptomicina, a rifampicina e a isoniazida. Para os do $2^{\circ}$ grupo, intracelulares destacam-se a pirazinamida e em menor grau a isoniazida, a rifampicina e o etambutol. Somente a rifampicina atua nos bacilos situados no $3^{\circ}$ grupo 223,236 .

Compreendeu-se, então, porque a combinação rifampicina + isoniazida + pirazinamida, seria o ideal para combater os 3 tipos de população bacilar que existem no tuberculoso, e assim, este esquema tríplice ficou consagrado em base experimental e na observação clínica ${ }^{223,236}$.

Atualmente, das 16 drogas conhecidas com ação efetiva sobre o bacilo da tuberculose, 6 são de uso preferencial: a estreptomicina $(\mathrm{S})$, a rifampicina $(\mathrm{R})$, o etambutol (E), a pirazinamida (Z), a etionamida (Et) e a isoniazida $(\mathrm{H}){ }^{191,193}$.

Novas drogas surgiram e têm despertado grande interesse, tais como os derivados da rifamicina, que são a rifabutina (que é dez vezes mais bactericida que a rifampicina e utilizada no tratamento de aidéticos), a rifampetina (também conhecida por DL473-ciclopentil rifamicina) e os derivados da quinolona que são o norfloxacin, ciprofloxacin, pefloxacin, defloxacin, enofloxacin, fleroxacin, ofloxacin e outros recentemente sintetizados ${ }^{191,236}$.

A quimioterapia deve impedir o desenvolvimento da resistência bacteriana, obter o mais rapidamente possível a negativação bacteriológica, conseguir a cura e evitar recaídas ${ }^{236}$.

No Brasil, a duração do tratamento é de 6 meses, e as drogas mais utilizadas são a rifampicina $(\mathrm{R})$, isoniazida $(\mathrm{H})$ e pirazinamida $(\mathrm{Z})$ nos 2 primeiros meses $\left(1^{\mathrm{a}}\right.$ fase) e nos últimos 4 meses ( $2^{\mathrm{a}}$ fase), apenas a rifampicina $(\mathrm{R})$ e isoniazida $(\mathrm{H})^{92,111,164,191,223,236}$. A contagiosidade cessa 1 mês após o início da quimioterapia ${ }^{160}$. Para os portadores de HIV ou pacientes com AIDS, a $2^{\text {a }}$ fase terá a duração de 7 meses (tratamento de 9 meses) ${ }^{142,164,191,193}$. Uma vez que o M.bovis é resistente à pirazinamida, ela deverá ser substituída por outra droga de $1^{\mathrm{a}}$ linha, para o efetivo 
tratamento dos infectados por esse agente ${ }^{92}$.

A interrupção precoce do tratamento possibilita a multiplicação das micobactérias que se encontravam em estado de semilatência, causando a recidiva da tuberculose. O bacilo, escapando às ações da droga, pode permanecer no interior do macrófago ou do caseum em estado de latência ou de atividade metabólica extremamente reduzida. Esta persistência bacteriana, após o tratamento de um paciente, explica a reativação de um foco tuberculoso considerado curado ${ }^{191,236}$.

A quimioterapia é totalmente impraticável em animais por causa do tempo de duração e alto custo do tratamento, a freqüente recorrência da doença quando o tratamento é interrompido e a possibilidade de desenvolvimento de cepas multidrogaresistentes (MDR) de M.bovis 115, 216, 228, 267 . Só é justificada para o tratamento de animais raros ou de grande valor genético 132, 265, 267, além de animais de boa produção ou de alto preço ${ }^{116,204}$.

O emprego dos fármacos necessários representa uma carga financeira desproporcional aos benefícios, além disso, não é imprescindível conservar a vida do paciente como ocorre na medicina humana. O bovino, por exemplo, deve proporcionar um rendimento determinado (gestação, parto, produção de leite e carne) e dele dependerá a rentabilidade de sua exploração ${ }^{281}$.

Entretanto, em um experimento controlado na África do Sul, entre 1958 e 1963, concluiu-se que a isoniazida era terapeuticamente efetiva contra a tuberculose bovina, mas tinha certas limitações na erradicação da doença ${ }^{216,228 .}$

Apenas isoniazida é usada para tratar o bovino tuberculoso por causa de sua alta especificidade, baixa toxicidade e baixo preço, em países que não podem adotar o abate dos reatores e indenização dos proprietários ${ }^{169,216}$.

\section{7- PREVENÇÃO E CONTROLE}

A experiência de muitos anos na luta contra as doenças infecciosas, demonstrou que o controle ou erradicação das mesmas, só é possível quando existe a 
aplicação simultânea de medidas de combate às fontes de infecção, aos animais susceptíveis e também às vias de transmissão ${ }^{224}$.

Onde há interação entre infecção em animais domésticos e selvagens, a erradicação da doença torna-se impraticável ${ }^{61,199,216}$. Infelizmente, controle não é sinônimo de erradicação, e no caso do M.bovis, devido ao seu longo período de latência em adultos, mesmo que se erradique a tuberculose bovina em um país, a população humana continuará portando a infecção por alguns decênios $125,154,184,298,301$.

Em 1941, Louis Dublin da Metropolitan Life Insurance Company, predisse que a tuberculose seria erradicada em 1960. O slogan da Associação Nacional de Tuberculose foi, por décadas, "Não tuberculose em 1960". Com a introdução da estreptomicina, ácido para-aminosalicílico e isoniazida no tratamento da tuberculose, nas décadas de 40 e 50, muitos experts em saúde pública e medicina preventiva predisseram a eventual eliminação da tuberculose como um problema de saúde pública, em uma ou duas décadas. Em 1958, James Perkins, propôs um sério desafio para um "programa concentrado formal de erradicação da tuberculose em toda a face da terra". No ano seguinte, a Arden House Conference on Tuberculosis em Harriman, Nova York, considerou a erradicação da tuberculose um objetivo primordial ${ }^{300}$.

Literalmente, erradicação de uma infecção quer dizer o desaparecimento da infecção e a extinção do patógeno responsável. Como o nome supõe, erradicação é um processo absoluto e não uma meta relativa. Em outras palavras, ela segue o princípio do fenômeno "tudo ou nada" 300.

Uma questão freqüentemente levantada em saúde pública é: Existe atualmente alguma doença completamente erradicada? Em princípio, é possível reduzir uma infecção ao grau de extinção ou erradicação? Teoricamente falando, a resposta é sim. Certos pré-requisitos, contudo, têm que ser satisfeitos: a doença não deve ter indivíduos portadores ou reservatórios animais, deve ser facilmente diagnosticada e possuir úteis instrumentos profiláticos ${ }^{300}$.

Pouquíssimas doenças podem satisfazer esses critérios, com as notáveis 
exceções da varíola e sarampo ${ }^{300}$.

Experiências obtidas no estudo de muitas doenças infecciosas demonstraram que no momento em que a morbidade de uma doença atinge um nível muito baixo, uma infecção residual, usualmente, persiste na população estabelecendo um estado de equilíbrio entre o agente, o hospedeiro e o ambiente, que são os componentes do processo doença. Um exemplo dessa ocorrência, é que apesar dos programas de erradicação da malária terem sido executados em muitas partes do mundo, por mais de 6 décadas, casos da doença ainda são relatados, esporadicamente, nas denominadas áreas erradicadas, sendo que alguns casos são importados e outros nativos $^{300}$.

Os Estados Unidos e países da Escandinávia iniciaram extensos programas de erradicação da tuberculose bovina no final da década de 30 e início da de 40 . O abate do bovino infectado foi um aspecto essencial do programa, mas apesar dessa medida, a erradicação bacteriológica não foi obtida. A doença, contudo, atingiu um baixíssimo nível, que permanece estável há muitos anos, e deverá continuar assim por décadas no futuro ${ }^{300}$.

Alguns pesquisadores, percebendo a dificuldade de se alcançar a erradicação bacteriológica da doença, preferem usar a frase "erradicação como um problema de saúde pública”, a qual significa apenas o controle substancial ${ }^{300}$.

No homem as principais medidas para o controle da tuberculose no Brasil, são: procura de casos, tratamento, vacinação BCG e quimioprofilaxia ${ }^{191,236}$. Nos bovinos, as ações profiláticas apoiam-se na instalação do diagnóstico precoce e no tratamento ou no sacrifício dos animais reatores à prova da tuberculina Tanto o tratamento quanto o sacrifício, envolvem posturas profissionais que são assuntos polêmicos, mas, em ambos os casos, de grande impacto econômico para o proprietário ${ }^{225}$. Os dados sobre taxas de prevalência e tendência da tuberculose bovina nos animais e no homem são essenciais para o planejamento e realização de qualquer programa de controle e erradicação ${ }^{56}$.

No homem, a procura de casos, ou seja, dos sintomáticos respiratórios 
bacilíferos é efetuada na comunidade ou na própria demanda de uma unidade de saúde (postos, centros e hospitais) por meio da prova tuberculínica (PPD) e da baciloscopia ou cultura ${ }^{191,193}$.

O tratamento correto dos bacilíferos é a atividade prioritária de controle da tuberculose, uma vez que permite anular rapidamente as maiores fontes de infecção ${ }^{193}$.

\subsection{1- VACINA BCG}

A história da imunização contra a tuberculose no homem é uma história de revés, controvérsia e surpresa. Esta história, com particular referência a vacinação BCG, tem sido revista 159, 193, 216. A errônea conclusão de Koch, em 1901 de que a tuberculose humana diferia da bovina e não podia ser transmitida ao gado, encorajouo a preparar uma vacina, para uso veterinário, com o bacilo da tuberculose humana supostamente atenuado. Esta vacina, denominada "Tauruman" e a similar "Bovo vacina" produzida por von Behring e seus colegas, alcançaram alguma popularidade até que Griffith em 1913 demonstrou que a vaca vacinada, embora não adoecesse, excretava bacilos da tuberculose humana viáveis e virulentos em seu leite $e^{68,110,127,228}$.

Acredita-se que o ponto de vista de Koch, influenciou Calmette e Guérin em sua escolha de uma cepa bovina para a preparação de uma vacina para uso no homem $^{68,127,228}$. O M.bovis, cepa BCG, foi originalmente isolado de uma cultura virulenta, obtida por Nocard, do leite de uma vaca tuberculosa. As passagens experimentais em meios de cultura foram realizadas por Calmette e Guérin em 1908, os quais obtiveram após 13 anos (1920) e 231 subcultivos, uma cepa atenuada denominada Bacille Calmette-Guérin (BCG). Observaram que o bacilo, por mutação, tinha se tornado avirulento, não sendo mais patogênico para o novilho nem para animais de laboratório, pois estes, além de não adoecerem, tornaram-se resistentes ao M.bovis e ao M.tuberculosis. Uma vacina viva atenuada, com esta cepa BCG, foi produzida para uso profilático em 1921 e utilizada em uma criança, em Paris, cuja mãe havia falecido tuberculosa $34,71,137,142,191,193,216,236$. 
Apesar de sua eficácia protetora não ter sido vigorosamente avaliada, esta vacina foi cada vez mais utilizada na Europa durante a década de 20, até que um terrível acidente ocorreu em Lubeck, Alemanha, em 1930, no qual 72 (28.7\%) de 251 crianças morreram de tuberculose fulminante, após poucos meses de vacinação com BCG via oral. Um inquérito revelou que M.tuberculosis virulento havia sido guardado no mesmo incubador, que continha a vacina, e tinha sido administrado às crianças, no lugar da mesma 33, 34, 223, 228, 236 . O acidente deixou Calmette tão arrasado, a ponto dele mesmo desencorajar o uso da sua vacina. Somente depois deste evento, foram organizados os testes de controle da $\mathrm{BCG}^{216}$. A vacinação BCG (no nascimento ou logo depois) é uma importante estratégia para o controle da tuberculose em países em desenvolvimento ${ }^{33,228,257 .}$

A vacina BCG é um método preventivo utilizado nos indivíduos não infectados pelo bacilo de Koch. Sua ação é exercida, ao promover um primeiro contato do sistema imunológico com o bacilo da tuberculose, preparando-o para responder prontamente às infecções posteriores. Na verdade, funciona como uma infecção natural controlada, ou seja, na qual a possibilidade de evoluir para doença é desprezível, em condições normais ${ }^{191}$.

A eficiência da vacina é convencionalmente expressa em termos de sua eficácia protetora, definida como a porcentagem de redução no risco de adoecimento entre os vacinados, quando comparados com indivíduos não vacinados e expostos ${ }^{216}$. Estudos retrospectivos evidenciaram que, em crianças, a aplicação do BCG diminuiu a incidência de formas graves da tuberculose, como a doença miliar e a meningite tuberculosa, ao prevenir a disseminação do bacilo de um foco primário da infecção $127,130,191,193,236,257$.

Após vários estudos, concluiu-se que a eficácia da vacina BCG é da ordem de 75-80\%, e que resultados inferiores a estes são devidos às condições locais, que variam de região para região, nos vários países onde ela é aplicada 33, 89, 209, 216. Apesar de não completa explicação, é muito provável que sua eficácia seja afetada por diferenças na exposição de diversas populações às micobactérias ambientais ou bacilo da tuberculose, antes da vacinação; às variações genéticas na população; à 
cepa BCG utilizada e à viabilidade do bacilo nas diferentes preparações da vacina $^{50,89,149,209,216}$. Há evidências de que a proteção conferida pelo BCG decresce com a idade e com o tempo que transcorre após a vacinação ${ }^{50}$.

No Brasil, a vacina BCG é indicada prioritariamente para as crianças da faixa etária de 0 a 4 anos, sendo obrigatória para crianças menores de um ano, como dispõe a Portaria no 452, de 06/12/76, do Ministério da Saúde ${ }^{191,193}$. Utiliza-se a sub-cepa BCG-Moreau, recebida em 1925 por Assis, proveniente do Instituto Pasteur de Paris e conservada, desde então, em condições adequadas à preservação de sua inocuidade e imunogenicidade ${ }^{34,236}$. A vacina BCG é fabricada pela Fundação Ataulpho de Paiva, no Rio de Janeiro. A dose vacinante de $0,1 \mathrm{ml}$ contem de 800 mil a 1 milhão de bacilos vivos atenuados, e é suficiente para induzir alergia tuberculínica, mensurável com PPD, na maioria das pessoas vacinadas ${ }^{191,236}$.

O BCG oral foi, até 1973, utilizado com exclusividade no Brasil, porém hoje, a aplicação da vacina é efetuada por via intradérmica, em dose única de $0,1 \mathrm{ml}$, no braço direito, na altura do músculo deltóide, em caso de primo-vacinação, e 1 a $2 \mathrm{~cm}$ acima, na revacinação 34, 93, 191, 193, 236, 257 . Essa localização permite a fácil verificação da existência de cicatriz para avaliação do programa e limita as reações ganglionares à região axilar. A vacina $\mathrm{BCG}$ pode ser aplicada simultaneamente com outras vacinas, mesmo com as de vírus vivos ${ }^{191,193}$.

Quando conservada a uma temperatura de 4 a $8^{\circ} \mathrm{C}$, mantém sua atividade pelo prazo de 1 ano. Ela perde sua potência se exposta à luz solar direta, ou difusa, se for congelada, e se for mantida à temperatura ambiente ${ }^{191}$.

O Brasil adota, até o momento, as recomendações feitas pela OMS em 1993, para países de alto risco para tuberculose, ou seja, vacinar todas as crianças assintomáticas, independente de serem soropositivas ou soronegativas para HIV, ou filhos de mães soropositivas. A vacina BCG está contra indicada apenas em crianças soropositivas para HIV que apresentarem sinais e sintomas de AIDS 33, 111, 142, 191. Como existem casos de disseminação de M.bovis em pessoas infectadas pelo HIV, a quem a vacina foi administrada, a OMS recomenda também sua contra-indicação para crianças mais velhas e adultos assintomáticos ${ }^{121}$. A literatura mundial relatou 
até 1994, 22 casos de complicações à vacina BCG em pacientes HIV-positivos (18 crianças e 4 adultos), sendo a maioria dos casos confirmada como M.bovis cepa $\mathrm{BCG}^{142,216,253}$.

A aplicação da vacina BCG no bovino tem sido abandonada no mundo todo, não apenas por causa de seu baixo efeito protetor, mas também porque a vacinação BCG resulta na sensibilidade à tuberculina e, portanto, interfere em um alto grau, em esquemas de erradicação da doença, nos quais a base do programa é o teste tuberculínico 2, 71, 89, 125, 149, 209,216,261.

Segundo uma declaração do WHO/FAO Expert Committee on Zoonoses, muitas dificuldades são inerentes à aplicação de qualquer esquema de vacinação, sendo um dos mais importantes, a condição essencial de que somente animais livres da doença sejam vacinados ${ }^{216}$. Entretanto, alguns autores apontaram a necessidade de se desenvolver uma vacina para o controle da tuberculose bovina, especialmente nos países tropicais, e sugeriram que testes fossem realizados com micobactérias de origem ambiental que não interferissem no teste tuberculínico $71,89,149,209,216$. Em alguns países, como a Índia, crenças religiosas não permitem o abate do bovino, assim, a proteção do gado e de outros animais de criação contra a tuberculose poderia ser feita por meio de vacinação; que seria uma alternativa apropriada, caso fosse utilizada uma vacina realmente eficaz ${ }^{129,212}$.

No caso da tuberculose por M.bovis, vacinas deveriam ser desenvolvidas também para reservatórios animais selvagens ou domésticos, ou ambos, desde que conferissem proteção custo-efetiva em nível populacional, e no caso de animais domésticos, não interferissem na detecção de animais infectados pelo teste da tuberculina. O uso de um teste capaz de discriminar entre infecção e vacinação, seria um complemento essencial para a introdução da vacinação de animais domésticos ${ }^{199,216}$.

Em princípio, parece provável que a vacinação poderia contribuir, substancialmente, para reduzir a origem da infecção em animais selvagens e, portanto, realizar facilmente o controle em animais domésticos ${ }^{149,199,216}$. Vacinas que estão sendo produzidas com Mycobacterium vaccae poderão provar, 
futuramente, sua utilidade para uso na população selvagem. A vacina com M.vaccae parece ter uma vantagem decisiva, obtida experimentalmente, ao demonstrar que múltiplas doses orais desta vacina não induziram positividade à tuberculina no gado. No entanto, a BCG permanece como padrão ouro, e por isso, qualquer outra vacina deverá ser pelo menos tão boa, ou melhor, que a BCG, em fornecer longo período de proteção ${ }^{149,216 .}$.

A persistência da tuberculose bovina no sudoeste da Inglaterra, República da Irlanda e Irlanda do Norte, a proteção estatutária dos texugos nesses países, e o alto custo das operações de controle desses animais, favorecem o desenvolvimento de uma estratégia de vacinação ${ }^{149,209}$. Realmente tem havido um considerável interesse, na possibilidade de prevenção da infecção tuberculosa em texugos por meio de vacinas $100,125,149,210,228$, mas 2 aspectos devem ser considerados para que isso ocorra. Primeiro, se os texugos possuem um sistema imune que poderia induzir um nível de proteção capaz de destruir ou conter o bacilo, e segundo, se é possível ou realístico administrar uma vacina em uma população de animais selvagens ${ }^{125}$.

Existem poucos dados publicados sobre os efeitos da vacinação BCG em texugos. Diversas vias de aplicação da vacina, incluindo a vacinação oral por meio de cápsulas, a administração via aerossol e a inoculação, são dignas de consideração ${ }^{149,209}$.

A vacinação oral por meio de cápsulas seria adequada, uma vez que estudos comportamentais realizados em texugos demonstraram que esses animais não manifestam uma ação competitiva quando se alimentam, não limitando as cápsulas a poucos animais dominantes em qualquer território estudado. Os texugos normalmente mastigam as cápsulas, e poderiam assegurar a presença da vacina na cavidade oral e não diretamente no estômago. Como as fêmeas regurgitam sua comida para alimentar os filhotes, teoricamente, a vacina poderia ser transferida aos mesmos. Ainda não há comprovação de que isto realmente aconteça ${ }^{149}$.

A aplicação via aerossol, provavelmente lançaria a vacina nos pulmões, que é o sítio primário da infecção por M.bovis. Para texugos cativos, esse tipo de vacinação seria possível; mas para a população nativa seria impraticável, principalmente se seus 
setts atingissem grandes profundidades. Além disso, a dose de vacina recebida por um texugo, que ocupasse qualquer sett, não poderia ser controlada e outros animais comensais seriam expostos à vacina ${ }^{149}$.

A aplicação por inoculação evitaria os problemas acima mencionados, mas envolveria a captura dos texugos, o que tornaria extremamente difícil a imunização de grandes populações desses animais. Entretanto, em um estudo realizado durante o verão, em Gloucestershire, Inglaterra, foi possível realizar a captura de $100 \%$ dos filhotes e $40 \%$ dos adultos, em apenas dois dias de trabalho. Além disso, existiria o risco de se vacinar uma população de texugos estressados, que produziria efeitos negativos indesejados no sistema imune do animal ${ }^{149}$.

Qualquer que seja o sistema de aplicação escolhido para um programa de vacinação, estudos que levem em consideração as variações sazonais no comportamento territorial, movimentos e reprodução dos texugos, devem ser realizados previamente. Esses padrões de comportamento podem favorecer a aplicação de uma vacina durante os meses de outono ou início de inverno ${ }^{149}$.

Pesquisas sobre o desenvolvimento de uma vacina para texugos estão sendo empreendidas na Irlanda do Norte desde $1995^{149,216,279}$. Os objetivos imediatos das pesquisas de campo no município de Cork, República da Irlanda são: desenvolver um efetivo sistema de aplicação oral e estabelecer o impacto da preparação de uma vacina com Mycobacterium vaccae morta e denominada Badge-Vac, na prevalência e severidade da tuberculose bovina em texugos, e no nível da doença no gado na área estudada. A dose de $10^{9}$ bacilos M.vaccae autoclavados, é misturada com amido de batata e lactose pulverizada, e embalada em cápsulas de gelatina tamanho 2. Essas cápsulas são revestidas com chocolate e servem como iscas para atrair os texugos, que as consomem rapidamente. Contudo, a quantidade dessas cápsulas é crítica, porque uma overdose pode causar rejeição, além de ser um risco para o gado doméstico que pode ingeri-las acidentalmente e passar a apresentar sensibilidade ao teste tuberculínico ${ }^{120,149,209,216 .}$

As cápsulas são distribuídas no início da primavera e final do outono de cada ano. Uma vez que as fêmeas de texugos amamentam seus filhotes por pelo menos 12 
semanas, durante um ano, e os filhotes não saem de seus setts no subsolo até que tenham no mínimo 2 meses de idade, muitos deles podem ser infectados com M.bovis antes de consumirem as iscas contendo a vacina. Há evidências de que os filhotes realmente abrigam uma considerável proporção de infecção por M.bovis ${ }^{149,216}$. Embora nenhuma vacina tenha conseguido proteger os texugos contra a infecção por M.bovis, acredita-se que o problema não poderá ser resolvido até que se consiga uma vacina eficaz ${ }^{279}$.

Segundo dados disponíveis, quando a vacina BCG foi administrada em gambás pela rota oral ou intra-gástrica, não apresentou efeito protetor. Sugeriu-se que a viabilidade da vacina havia sido reduzida pela exposição às secreções gástricas e baixo $\mathrm{pH}^{149}$.

A vacinação pelo BCG tem sido capaz de produzir uma boa imunidade em macacos, sob condições experimentais, entretanto, seu uso é desaconselhado porque mascara o teste da tuberculina ${ }^{216}$.

A identificação de fatores responsáveis pela virulência micobacteriana, e pesquisas para mapear e sequenciar o genoma de muitas micobactérias, poderiam fornecer as informações necessárias para a produção de cepas micobacterianas atenuadas, que substituíssem a cepa BCG. A adequada atenuação de cepas bacterianas patogênicas requer o rompimento de genes definidos. Esta tecnologia ainda está pouco avançada para micobactérias, particularmente, para M.bovis e M.tuberculosis, os quais tendem a incorporar DNA alheio em seus cromossomas, produzindo cepas mutantes. Em longo prazo, devido a recentes progressos na manipulação genética de micobactérias, o desenvolvimento de cepas avirulentas de M.bovis com mutações definidas, poderá fornecer os mais importantes candidatos para novas vacinas ${ }^{209}$.

\subsection{2- QUIMIOPROFILAXIA}

A quimioprofilaxia significa o uso de drogas capazes de prevenir a infecção ou impedir que o indivíduo infectado adoeça. Mc. Dermot estabeleceu a 
quimioprofilaxia primária e secundária ${ }^{57,191,236}$.

A quimioprofilaxia da tuberculose no homem consiste na administração de isoniazida em pessoas não infectadas, com a finalidade de prevenir a evolução da infecção caso esta venha a ocorrer (quimioprofilaxia primária), e em pessoas infectadas (PPD reator forte), mas sem sinais de doença tuberculosa, para prevenir a evolução da infecção à doença (quimioprofilaxia secundária), na dosagem de $10 \mathrm{mg} / \mathrm{kg}$ de peso (até 400mg) diariamente, durante 6 meses ${ }^{3,142,191,193,223,236,257}$. A isoniazida foi escolhida pelo seu alto poder bactericida, poucos efeitos colaterais e baixo custo ${ }^{236}$.

O M.bovis é usualmente sensível à isoniazida, rifampicina e etambutol, mas não à pirazinamida. Apesar da profilaxia com isoniazida parecer apropriada para indivíduos infectados, mas, sem a doença ativa, o grau de proteção oferecido pela profilaxia para casos de infecção por M.bovis, não foi estudado ${ }^{108,216}$.

Portanto, a profilaxia do homem contra a infecção pelo bacilo bovino consiste principalmente no saneamento dos rebanhos infectados; em evitar, sempre que possível, o contato prolongado com esses animais; e especialmente, na proibição de beber leite não fervido ou não pasteurizado. Além disso, a higiene pessoal dos trabalhadores, rurais e a vacinação BCG para as crianças, são igualmente elementos profiláticos $93,254,282$.

As medidas profiláticas para os bovinos, contra a infecção pelo M.bovis, consistem na tuberculinização dos animais; na boa alimentação; na verificação da existência de portadores da infecção entre os ordenhadores, peões, suínos, gatos, cães e outros animais da propriedade; na atenção especial ao manejo do rebanho, para que os animais não tenham contato com outro bovino infectado através de cercas, dos alimentos e da água servida em cochos e bebedouros comuns; na observação constante do comportamento dos animais, por parte do fazendeiro e seus empregados, para saberem os que apresentam algum sintoma clínico; na higiene e desinfecção dos estábulos, bebedouros e currais usados por animais doentes; no aleitamento de bezerros com leite de vacas sadias e finalmente, na aquisição de animais somente com atestado negativo de tuberculinização ${ }^{116}$. 


\subsection{3- CONTROLE DA TUBERCULOSE BOVINA}

\section{a) No mundo.}

O método básico para a erradicação da tuberculose no bovino é a aplicação da prova tuberculínica intradérmica e a eliminação de todos os reatores positivos, enviando-os diretamente a um matadouro, o mais rapidamente possível $2,53,54,56,75$, 93, 199, 228, 237, 254, 259, 281 . Entretanto, como acontece na maioria das provas biológicas, o teste da tuberculina tem suas falhas, sendo a mais grave a frequiência de resultados negativos, nos estágios muito avançados da doença. Esta ocorrência é particularmente séria nas campanhas de erradicação da tuberculose bovina, todas elas baseadas na prova de tuberculina, porque pode poupar do isolamento ou sacrifício justamente os animais mais contagiantes na propagação da moléstia. Por isso, para se erradicar a tuberculose de um rebanho bovino, não basta apenas um teste tubercuínico; este deve ser repetido periodicamente e ser acompanhado da observação cuidadosa de cada animal, visando surpreender os casos que possam ter escapado à prova alérgica ${ }^{229,} 267$.

Nos países onde existem avançados programas de erradicação da tuberculose, o descobrimento de rebanhos afetados será baseado na confirmação laboratorial de lesões semelhantes à tuberculose, encontradas na inspeção de matadouros, durante o sacrifício dos animais $53,54,56,228,237$. O matadouro tem sido utilizado desde a sua introdução em Roma por Galeno, até os dias atuais, como instrumento de profilaxia das doenças transmissíveis e de vigilância epidemiológica, possibilitando o rastreamento e a descoberta de áreas de alto risco e dos focos das doenças ${ }^{232}$.

O método usado em muitos países europeus para eliminar bovinos tuberculosos dos rebanhos, como descrito por Bang em 1892, na Dinamarca, incluía a segregação dos animais tuberculina-positivos do resto do rebanho $2,92,110,196,228,237$. Os casos clínicos eram abatidos, os não reatores eram retestados a cada 6 meses, ou a cada ano, e os reatores removidos novamente. Os bezerros dos reatores eram removidos no nascimento e alimentados com leite de animais não reatores ou leite 
pasteurizado ${ }^{228,} 237$. Isto requeria o sustento e manutenção dos dois rebanhos separados e provou ser um lento processo, que prolongava a presença da tuberculose bovina nas regiões onde era aplicado ${ }^{92,228}$.

O sucesso dos esquemas de erradicação da tuberculose depende da eficiência na detecção e remoção dos animais infectados antes que eles atinjam os estágios iniciais da doença $92,228,281$. Por essa razão, as medidas de controle defendidas por Ostertag, um veterinário alemão, no qual apenas os animais com evidência clínica ou bacteriológica da doença eram removidos, estava destinado ao fracasso ${ }^{2,68,92,237}$. O método consistia no exame regular do rebanho, identificação e abate dos casos clínicos e ao mesmo tempo a remoção de bezerros no nascimento, alimentando-os com leite de vacas sadias ou leite pasteurizado ${ }^{92,110,228}$.

Este método foi modificado nos Estados Unidos e aplicado em muitos outros países, consistindo no abate de todo o gado tuberculina-positivo, com ou sem sinais clínicos da doença, e indenização dos proprietários ${ }^{92,228,237}$. A primeira cidade a aplicar esse programa de erradicação foi Washington, em $1906{ }^{92}$. Neste ano, nos Estados Unidos, houve o reconhecimento de que $25 \%$ das mortes por tuberculose em seres humanos eram devidas ao M.bovis, mas programas de erradicação da tuberculose no gado, no país todo, só foram iniciados em $1917^{42,110,228}$. Na Europa, um dos últimos países a adotarem esse sistema foi a Grã-Bretanha, em 1935, sendo ainda extremamente prejudicado durante a $2^{\mathrm{a}}$ Guerra Mundial, e não completo até $1960^{1,68,92,125,127,148,228 .}$

Um fato interessante prejudicou o desenvolvimento da campanha de erradicação da tuberculose nos Estados Unidos. Era inevitável que um grande número de criadores não concordasse em sacrificar os animais que, embora reagentes à tuberculina, apresentavam excelente aspecto exterior e cujo rendimento era idêntico, na ocasião do teste positivo, ao dos bovinos sem reação à tuberculina. A maneira mais simples, encontrada pelos criadores, para se livrarem do prejuízo imediato que lhes adviria do sacrifício de animais reagentes, foi a de não permitir que seu gado fosse submetido à prova ${ }^{110}$.

Com esta recusa entravam em conflito com a legislação em vigor, que tornava 
obrigatória a prática da prova tuberculínica nos rebanhos e, em inúmeras ocasiões, a disputa judicial chegava à Corte Suprema, que decidia a favor do veterinários. Frustrada a recusa, muitos criadores passaram a recorrer ao uso fraudulento da tuberculina, que injetada em grandes doses por via subcutânea no animal, tornava-o insensível durante várias semanas ao teste tuberculínico. Desse modo, conseguiam a permissão para a venda de animais infectados e temporariamente negativos à tuberculina $^{110}$.

Para impedir a fraude, foram promulgadas leis estabelecendo quarentena para os animais que seriam transferidos de um município, ou de um Estado para outro, assim como para os importados de outros países ${ }^{110}$.

Nessa época, fazendeiros da Irlanda, onde o bovino era essencial para a economia do país, também praticavam essa fraude. Infelizmente, outras técnicas de fraudes foram desenvolvidas com o passar dos anos e investigações realizadas em 1994, por Monaghan e col. (1994) ${ }^{197}$, em fazendas da Irlanda, constataram a utilização de dexamethasona em grupos de bovinos, naturalmente ou artificialmente sensibilizados, durante o teste tuberculínico. A administração desse medicamento reduzia muito o tamanho das reações à tuberculina, resultando na classificação da maioria dos bovinos tuberculosos como negativos ao teste tuberculínico ${ }^{197}$.

Nos anos 50 e 60, esforços consideráveis foram aplicados no mundo inteiro para combater a tuberculose bovina. Em numerosos países desenvolvidos, os casos tornaram-se raros e em alguns outros, a situação foi muito melhorada pela redução da incidência da doença. Alguns países passaram da tuberculinização voluntária à tuberculinização obrigatória, mas o abate dos animais reagentes necessitava de recursos financeiros suficientes para indenizar os criadores. E era na América do Sul, continente que possuía a população bovina mais numerosa, que a incidência da doença parecia ser a mais elevada ${ }^{160}$.

Segundo um Grupo Especial de Trabalho, reunido no México em 1988, durante o $2^{\circ}$ Simpósio Internacional sobre Tuberculose, seria necessário que se adotassem leis sobre a identificação e o movimento de animais, reações de tuberculina e quarentena de rebanhos. Este grupo definiu de maneira categórica, a 
necessidade de se empregar somente veterinários credenciados e registrados pelo Ministério da Agricultura, para a realização dos procedimentos do programa. De acordo com suas observações, um dos fatores primordiais na realização de programas seria a educação rural, anterior aos mesmos, com o objetivo de se obter uma total colaboração dos proprietários de bovinos, a fim de convencê-los que os benefícios superariam o custo, com o aumento da produtividade e o melhoramento da saúde pública ${ }^{56}$.

Necessitava-se também da colaboração dos sindicatos de trabalhadores de gado, das associações de fazendeiros, dos empacotadores de carne, da indústria leiteira, das cooperativas agrícolas e outras instituições ou órgãos privados interessados na saúde humana e animal ${ }^{56}$.

Para garantir a continuidade do programa seria da maior importância que se fizesse uma estimativa realista dos custos totais, que seriam definidos sobre uma base anual e por um período de 4 anos. A supervisão da inspeção de carne seria essencial para um programa econômico e efetivo, pois o custo de provas tuberculínicas extensivas e continuadas seria proibitivo e a erradicação adiada ${ }^{56}$.

Um programa nacional só alcançaria êxito, se fosse aplicado inicialmente em uma área pequena e expandindo-se à medida que a organização alcançasse maior experiência e eficiência operativa. A escolha da área deveria se basear nos seguintes fatores: na baixa prevalência de enfermidade, na disponibilidade de gado de reposição e na vontade da indústria pecuarista de apoiar o programa ${ }^{56}$.

Seriam declaradas Áreas Certificadas Livres de Tuberculose Bovina, aquelas com 5 anos de ausência de detecção de M.bovis, com vigilância e identificação de animais adequadas, e que mantivessem um bom registro dos procedimentos efetuados 56 .

Além do abate de todo o gado tuberculina-positivo, que constituem a fonte primária da infecção, deveria ser dada atenção especial ao adequado e oportuno tratamento e desinfecção das fontes secundárias da infecção, nas quais os bacilos se conservam viáveis durante períodos variáveis de tempo, que são: fezes (esterco), 
água, superfícies (sobre superfícies de cimento permanecem viáveis por até 37 dias), instalações, instrumentos cirúrgicos, equipamentos e outros ${ }^{35,118,273}$. Essas fontes secundárias poderiam estar contribuindo para a manutenção da tuberculose bovina no mundo, e retardando o sucesso dos programas de controle ${ }^{273}$.

Consequentemente, medidas para prevenir a transmissão da infecção, deveriam ser o principal objetivo de qualquer programa de controle. Boas práticas higiênicas no manejo, incluindo a quarentena dos animais adquiridos recentemente, para prevenir a introdução de animais infectados no rebanho; a pasteurização do leite; um bem treinado e organizado serviço de saúde pública e a população corretamente informada, seriam fundamentais para a realização desse objetivo $89,93,199,216,281$.

Quanto à importância do laboratório em um programa de controle, Wedman da Universidade de Iowa, Estados Unidos, insistia em que "a assistência do laboratório deveria ser parte integral de qualquer programa para o controle e erradicação da tuberculose animal encarregando-se de isolar e identificar microrganismos de lesões suspeitas de serem tuberculosas" 8 .

Atendendo à solicitação dos Ministros da Agricultura dos países das Américas (Norte, Latina e Caribe) durante a VII Reunião Interamericana de Saúde Animal a Nível Ministerial, realizada em Washington, em abril de 1991, o Diretor da Organização Panamericana de Saúde (OPS/OMS), convocou uma Reunião Internacional para a Erradicação da Tuberculose Bovina em Saltillo (Coahuila), México, entre 18 e 20 de novembro de 1991, na qual estavam presentes representantes de 20 países americanos, diversos órgãos e instituições de cooperação técnica e investigação, tanto nacionais como internacionais, além de várias associações mexicanas de criadores de gado 217,218 .

Neste evento, se fez uma revisão da situação epidemiológica da doença, analisaram-se os progressos tecnológicos disponíveis, particularmente em matéria de diagnóstico, houve intercâmbio de informações atualizadas acerca do estado em que se encontravam os programas em execução, em diferentes países da Região, e se considerou uma proposta de Plano de Ação para a Erradicação da Tuberculose Bovina nas Américas, constituindo um marco programático para um Programa 
Hemisférico de luta contra a doença ${ }^{217,218}$.

Durante a primeira fase de 10 anos esperava-se consolidar as metas de erradicação dos países que tinam programas avançados. Nos demais países houve fortalecimento da vigilância epidemiológica para conhecer a situação real da enfermidade, definição das áreas de risco e estabelecimento de programas adequados de controle e erradicação ${ }^{217,}{ }^{218}$. Seriam declaradas, oficialmente, isentas de tuberculose bovina, as regiões e os rebanhos que tivessem obtido resultados negativos em um mínimo de 3 provas tuberculínicas, aplicada a todo o bovino maior de 6 semanas de idade ${ }^{217,237 .}$.

Em 1993, um grupo de trabalho da WHO, concluiu que o teste da tuberculina e o método de abate do bovino tuberculoso deveriam permanecer como a política central para o controle da tuberculose no gado, nos países em desenvolvimento. Entretanto, modificações de algumas práticas (pelo fato de ser proibitivamente caro para algumas nações) como a segregação e abate periódico dos reatores, seriam necessárias, em certas situações. Manifestaram preocupação em relação à eficácia da vacinação e subsequente interferência com o teste da tuberculina, e também aos riscos associados com a quimioterapia, devido à possibilidade de resíduos das drogas entrarem na cadeia alimentar e contribuírem para o desenvolvimento de micobactérias multidroga resistentes (MDR) 89, 129, 216, 295, 296.

Na região das Américas, de maneira geral, em 1995 foram observadas baixas frequiências de tuberculose bovina, nos países com programas sistemáticos de controle e erradicação, que foram executados no Canadá, Estados Unidos, Costa Rica, Cuba, Jamaica, Panamá e Uruguai. Nos países tropicais, os focos de infecção detectados se encontravam nas bacias leiteiras, nas quais se praticavam sistemas intensivos de produção ${ }^{218}$.

A análise da situação epidemiológica atual da tuberculose bovina nas Américas, baseou-se nos informes remetidos pelos países à OPAS, durante o período 1990-1994, e nas informações contidas no Anuário de Saúde Animal entre 19901993. Em função da prevalência da doença os países foram agrupados em 3 categorias: 
a) países que estavam livres ou que apresentaram prevalências menores que $0,1 \%$ e que em conjunto concentravam 37,7\% (164,4 milhões) da população bovina estimada, de toda a região das Américas. Nesta categoria estavam os países e territórios do Caribe (com exceção do Haiti) e República Dominicana, América do Norte (Estados Unidos e Canadá) além de Belize, Colômbia, Cuba, Panamá, Uruguai e Venezuela ${ }^{217,218 .}$

b) países com prevalências superiores a $0,1 \%$, nos quais a população bovina estimada alcançava 251,3 milhões de cabeças (57,6\% do total). Eram eles: República Dominicana no Caribe; Costa Rica e Guatemala na América Central; México, país com situação completamente diferente conforme fossem áreas leiteiras ou de carne; e, na América do Sul, Argentina, Brasil, Chile e Paraguai ${ }^{218}$.

c) países dos quais se desconhecia a prevalência da tuberculose bovina ou os dados oficiais disponíveis eram escassos ou desatualizados, com um total estimado de 20,5 milhões de bovinos (4,7\% do total). Neste grupo incluíam-se: Bolívia, Equador, El Salvador, Guiana Francesa, Guiana, Haiti, Honduras, Nicarágua, Peru e Suriname $^{218}$.

Em relação à situação dos programas de controle e erradicação da tuberculose bovina, até 1996, os dados disponíveis indicaram o seguinte:

- Na América do Norte, os Estados Unidos continuavam com seu programa de erradicação da tuberculose bovina, e esperavam alcançar essa meta em 1998. Neste país, 41 Estados consideravam-se "livres" da doença ${ }^{218}$.

- O Canadá, cujo programa de erradicação iniciou-se em 1923, com uma prevalência de tuberculose bovina no gado, estimada em 4\%, a partir de 1978, incluiu no programa o abate de todo o animal tuberculoso ou exposto, suspendendo a tuberculinização de rotina dos rebanhos bovinos e implementando um sistema de vigilância epidemiológica em matadouros. Em 1993, de quase 2,5 milhões de bovinos sacrificados, apenas 158 tiveram lesões compatíveis com tuberculose bovina. Em 1994, não se encontrou nenhum rebanho infectado com M.bovis, e nem se isolou esse agente das lesões granulomatosas de porcinos, que 
são submetidas rotineiramente aos laboratórios de diagnóstico ${ }^{106,218}$.

- O México, em 1993 submeteu seu programa a uma revisão, fortalecendo-o nas áreas das bacias leiteiras onde, apesar de possuírem uma quantidade menor de gado (entre um quinto e um sexto da população bovina total), a prevalência de tuberculose bovina era várias vezes superior (aproximadamente 2\%) à que se observava nas áreas com predomínio de gado de corte (cerca de 0,1\%). Dados de 1995 indicaram que foram examinados 38.562 rebanhos e 2,37 milhões de bovinos, dos quais $0,23 \%$ resultaram reatores à prova tuberculínica $156,218,276$.

- Cuba, iniciou seu programa em 1964 e a doença foi considerada eliminada desde 1984 55, 156, 218, 219. Entretanto, um estudo retrospectivo efetuado a partir da detecção de animais com lesões compatíveis em matadouros, conduziu ao abate 2 rebanhos bovinos em 1993, e 97 búfalos em $1994^{55,218}$.

- A Jamaica, no período de 1992-1993 submeteu à tuberculinização uma importante proporção de seu rebanho bovino, sem encontrar reatores e tampouco animais com lesões compatíveis com a enfermidade, durante a inspeção de matadouros. As autoridades nacionais esperavam, em curto prazo, a certificação de país "livre" da doença ${ }^{218}$.

- Em El Salvador, em 1994, iniciou-se um projeto piloto de controle da brucelose e tuberculose, cuja ação e resultados, esperava-se que pudessem ser estendidos aos países afetados por estas doenças, na sub-região centro-americana ${ }^{218}$.

- O Panamá, em 1993, declarou-se "livre" da tuberculose bovina 156, 218.

- A Argentina, em 1983, iniciou um programa de saneamento, sobre base voluntária, nos grandes estabelecimentos de criação de bovinos, que continuava desenvolvendo-se, e em 1994, formulou um Programa de Controle e Erradicação da Tuberculose Bovina ${ }^{55,218}$.

- O Chile ampliou a cobertura do programa de luta contra a tuberculose, que estava circunscrito fundamentalmente no Sistema de Certificação de Propriedades Livres de Brucelose e Tuberculose Bovina, cuja meta era a de manter em um esquema 
voluntário, 2000 propriedades na condição de "livres", com monitoramento periódico e sistemático ${ }^{218}$.

- Uruguai, país que tinha uma baixa prevalência de tuberculose bovina, iniciou a

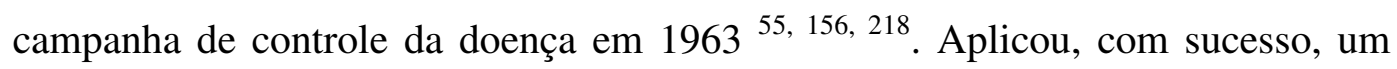
programa de eliminação da febre aftosa e elaborou um projeto priorizando a erradicação da brucelose e tuberculose bovina ${ }^{55,218}$. A prevalência da infecção por M.bovis em 1994, foi de $0,005 \%{ }^{156}$.

- Equador e Bolívia não possuíam informações disponíveis sobre o status da tuberculose bovina, mas dados de 1980, provenientes de estudos realizados no gado leiteiro, indicaram a prevalência de $12,7 \%$ e a presença de animais infectados em $18,6 \%$ dos rebanhos ${ }^{156}$.

- Colômbia, onde a enfermidade era de relativamente recente introdução, e com uma distribuição circunscrita somente a certas áreas de seu território, mantinha um programa de erradicação que não tinha conseguido consolidar-se plenamente $^{156,218}$.

- Venezuela, durante mais de 20 anos realizou um intenso trabalho de tuberculinização dos rebanhos bovinos (726.000 em 1993) e de eliminação dos reatores, conseguindo reduzir substancialmente a taxa de animais tuberculinapositivos $(0,02 \% \text { em } 1993)^{218,284}$.

Em 1996, programas de eliminação da tuberculose bovina no gado estavam em progresso na Austrália e Nova Zelândia, no Leste Europeu, Israel, e Japão ${ }^{196}$.

Nos países com programas efetivos de eliminação da tuberculose bovina, os principais problemas são:

$\Rightarrow$ o risco de reintrodução da doença pelos países vizinhos, nos quais a doença não tem sido eliminada;

$\Rightarrow$ a presença de várias espécies animais domésticas e selvagens, que podem agir como hospedeiros ou reservatórios da doença; 
$\Rightarrow$ a transmissão da infecção do bovino para humanos;

$\Rightarrow$ a presença de humanos imunodeprimidos por HIV/AIDS, com maior susceptibilidade à doença evidente após a infecção por M.bovis;

$\Rightarrow$ a crença por parte de alguns clínicos e veterinários que o M.bovis é de baixa virulência para humanos, e o fato de que o risco ocupacional, pela exposição profissional, é freqüentemente ignorado;

$\Rightarrow$ a freqüente falta de comunicação entre médicos e veterinários, resultando em uma falha na condução de investigações epidemiológicas completas e rastreamento dos contatos;

$\Rightarrow$ a transmissão de bacilos resistentes às drogas antituberculosas de $1^{\mathrm{a}}$ linha, pois a administração de isoniazida para o bovino pode ter favorecido o aparecimento de cepas resistentes de M.bovis ${ }^{196}$.

Para os países em desenvolvimento, a ameaça para a saúde pública da infecção por M.bovis e doença em animais domésticos e selvagens, é um grande problema, porque:

- não existem dados ou levantamentos a respeito da prevalência da doença nesses locais;

- os custos para o controle da tuberculose nos animais e para a inspeção de carnes e outros produtos animais, geralmente excedem os recursos disponíveis e, consequentemente, programas limitados têm pouco impacto;

- a tuberculose por M.bovis é subestimada;

- a falta de precauções básicas de saúde pública, como a pasteurização do leite, aumenta o perigo da infecção, particularmente para crianças;

- o problema é acentuado em algumas áreas por má nutrição ou fome, atingindo pessoas, particularmente crianças que são mais susceptíveis às formas severas de tuberculose, uma vez que nestas condições, todas as 
formas disponíveis de alimentos são consumidas, incluindo carne e leite de animais doentes ${ }^{196}$.

A União Européia (E.U.) incluiu a tuberculose devida ao M.bovis entre as 4 principais zoonoses que requerem vigilância específica e programas de investigação ${ }^{196}$.

\section{b) No Brasil}

No Brasil, as atividades de controle da tuberculose bovina iniciaram-se em 1936 com a tubercullinização do gado leiteiro, mas não havia qualquer medida compulsória para a eliminação dos reagentes. Em 1939, 2 decretos do governo de São Paulo, sanavam as falhas na produção e distribuição do leite, instituindo para a capital e várias cidades do interior, a obrigatoriedade da pateurização do leite e estabelecendo normas de engenharia sanitária que deveriam ser obedecidas na construção e manutenção de estábulos ${ }^{110}$.

Atualmente, essas atividades são executadas pelo Ministério da Agricultura, Secretarias de Agricultura Estaduais e entidades afins, mediante convênios celebrados entre as partes, contando ainda com a colaboração de médicos veterinários autônomos $188,189,190$.

No ano de 1987 foi firmado um Termo de Contrato entre o Banco Mundial e o Ministério da Agricultura, para a execução do Projeto de Controle das Doenças dos Animais, no qual a tuberculose foi contemplada. No entanto, apenas 14 Unidades da Federação foram beneficiadas, sendo incluídas as seguintes, por região:

- Nordeste - CE, PE e BA;

- Centro-oeste - MT, MS, GO e DF;

- Sudeste - MG, ES, RJ e SP;

- Sul - PR, SC e RS ${ }^{188}$.

As atividades relativas à tuberculose bovina são realizadas com maior 
intensidade nas granjas leiteiras produtoras de leite do tipo A e B e, com menor intensidade, no controle do trânsito de animais nas feiras e exposições agropecuárias $^{188,189,190 .}$.

Uma das fases do programa de controle e combate à tuberculose bovina, é a realização de exames para o diagnóstico da enfermidade, mediante as provas de tuberculinização dos animais. Dependendo do resultado do exame, os animais são classificados em negativos, suspeitos ou positivos a tal prova ${ }^{189,190}$. Tendo em vista que os animais suspeitos estão potencialmente predispostos à positividade, costumase somar os dois para uma melhor análise epidemiológica da enfermidade ${ }^{188,189}$. Embora não haja uma programação com recursos específicos para a indenização de animais sacrificados, bovinos com tuberculose são abatidos em todo o país, devido à conscientização dos criadores ${ }^{188,189,190 .}$

A tabela 2 demonstra os resultados do programa no período de 1986-96, sendo que os dados referentes ao período de 1994 a 1996 eram provisórios e fornecidos, pessoalmente, pelo Ministério da Agricultura, em Brasília 188, 189, 190. 


\section{Tabela 2 - Demonstrativo epidemiológico da tuberculose bovina no}

\section{Brasil (1986 - 1996)}

\begin{tabular}{c|c|c|c|c|c|c|c}
\hline ANOS & $\begin{array}{c}\text { FOCOS } \\
\text { (Propriedades } \\
\text { Positivas) }\end{array}$ & $\begin{array}{c}\text { ANIMAIS } \\
\text { TUBERCULINIZADOS }\end{array}$ & \multicolumn{3}{|c|}{ REAGENTES } & PREVALÊNCIA & $\begin{array}{c}\text { ANIMAIS } \\
\text { SACRIFICADOS }\end{array}$ \\
\cline { 4 - 5 } 1986 & 657 & 353.351 & 608 & 3.090 & 3.698 & 1,05 & $\ldots$ \\
1987 & 508 & 342.283 & 647 & 2.530 & 3.177 & 0,93 & 209 \\
1988 & 586 & 340.899 & 1.208 & 2.262 & 3.470 & 1,02 & 162 \\
1989 & 519 & 284.930 & 791 & 1.850 & 2.641 & 0,93 & 141 \\
1990 & 526 & 290.042 & 1.070 & 2.262 & 3.332 & 1,15 & 668 \\
1991 & 702 & 389.832 & 1.562 & 3.268 & 4.830 & 1,24 & 542 \\
1992 & 997 & 533.435 & 3.374 & 5.652 & 9.026 & 1,69 & 148 \\
1993 & 950 & 422.475 & 1.819 & 3.873 & 5.692 & 1,35 & 455 \\
$1994 *$ & 690 & 411.904 & 1.456 & 3.604 & 5.060 & 1,23 & 511 \\
$1995^{*}$ & 431 & 341.316 & 1.330 & 2.161 & 3.491 & 1,02 & 575 \\
$1996^{*}$ & 817 & 452.071 & 2.180 & 3.743 & 5.923 & 1,31 & 594 \\
\hline TOTAL & 7.383 & 4.162 .538 & 16.045 & 34.295 & 50.340 & 1,17 & 4.005 \\
\hline
\end{tabular}

(*) 1994, 1995, 1996 = dados provisórios fornecidos pessoalmente pelo Ministério da Agricultura, em Brasília.

\section{$(\ldots)=$ sem informação}

FONTE: Boletim de Defesa Sanitária Animal - Ministério da Agricultura e do Abastecimento 
Pelos dados observados na tabela 2 , constata-se que a prevalência da tuberculose bovina aumentou em $1992{ }^{104}$, sofreu uma queda gradativa até 1995, para em 1996 apresentar um novo aumento ${ }^{50}$.

No Brasil, o comércio clandestino (envolvendo compra e venda de bovinos doentes, laticínios contaminados, fabricação de carimbos da inspeção sanitária, currais de aparência medieval escondidos na periferia das metrópoles), apesar de proibido por ameaçar a saúde pública, é uma triste realidade ${ }^{9}$.

Em relação à carne bovina e ao leite para o consumo humano, a legislação brasileira manda abater os bovinos com tuberculose, mas nem sempre a lei prevalece e o próprio governo admite o comércio de gado com tuberculose no país ${ }^{11}$.

Entre janeiro e maio de 1998, notificaram-se no Ministério da Agricultura 257 casos de tuberculose bovina, mas o rebanho brasileiro soma 153 milhões de cabeças de gado. Portanto, os dados estatísticos disponíveis no Brasil, fornecem uma noção muito limitada do problema, não espelhando a realidade da doença no país ${ }^{11}$.

Quanto ao comércio clandestino do leite, devido às falhas na legislação e falta de estrutura, os governos estaduais não conseguem cadastrar todas as vacas leiteiras do país. Consequentemente, não possuem o histórico sanitário dos animais e nem ficam sabendo se mudaram de dono. Como as vacas tuberculosas, geralmente, exibem boa aparência, há proprietários que, em vez de descartá-las, as vendem. Por esse motivo, é possível encontrar vacas doentes de criadores legalizados e cujo abate havia sido recomendado por veterinários, em rebanhos de produtores de leite clandestino ${ }^{11}$.

A lei manda que, antes do consumo, o leite de vaca e seus derivados passem pela fiscalização sanitária do governo. O crivo deve ocorrer nas usinas de beneficiamento, onde o produto líquido e ainda cru precisa se submeter à pasteurização ou outros processos industriais que incluem o aquecimento a altas temperaturas, uma vez que o leite está entre os meios mais propícios à proliferação de microrganismos, destrutíveis pelo calor. Se não atendidas regras rígidas de produção, embalagem, transporte e armazenamento, o leite pode transmitir um 
número razoável de doenças, da tuberculose às diarréias ${ }^{9}$.

Apesar da lei, um recente trabalho do Pensa (programa da Universidade de São Paulo, que estuda o agrobusiness brasileiro) apontou para um quadro alarmante: $41 \%$ do leite bovino que se produziu no país em 1997 tinham origem clandestina, ou seja, dos 20 bilhões de litros produzidos, 8,2 bilhões de litros chegaram até o consumidor sem passar pelas usinas de beneficiamento, sem pagar impostos e, o mais perigoso, sem o aval da inspeção sanitária. Os brasileiros consumiram esse leite clandestino de 3 modos diferentes: na forma líquida (6 bilhões de litros), como queijo (200 mil toneladas) e como iogurte ou bebida láctea (80 mil toneladas) ${ }^{9}$.

Outra constatação importante foi a de que a informalidade do comércio clandestino está crescendo. Em 1990, a produção de leite ilegal atingiu 5 bilhões de litros e entre 1994 e 1995 já alcançava a casa dos 7 bilhões de litros. A distribuição clandestina do produto na forma líquida é feita às claras, quase sempre sem refrigeração, em peruas, carroças e até motocicletas. Muitos vendedores negociam o leite a granel, transportando-o em latões, e o comprador o recolhe com vasilhas. Outras vezes, a bebida chega em embalagens sem rótulo (normalmente sacos plásticos ou garrafas de refrigerante) ${ }^{9}$. Uma prática comum entre criadores clandestinos é a de "batizar" o leite, até mesmo com água não potável, para que renda mais. Essa fraude, além da fabricação de queijos e outros laticínios com matériaprima contaminada, colocam em risco a saúde do consumidor ${ }^{14}$.

Fabricantes clandestinos de queijo estão falsificando o carimbo do governo que é a garantia de que o produto passou pela fiscalização sanitária. De acordo com a legislação brasileira, só é permitido vender laticínios que exibam um carimbo dos serviços de inspeção federal (SIF), estadual (SISP, por exemplo) ou municipal (SIM). Às siglas, associa-se sempre um número, que identifica o produtor nos cadastros do governo. As fraudes estão se concretizando de quatro maneiras: os falsificadores reproduzem a embalagem, o rótulo e o número de uma queijaria que já fechou; criam uma marca nova, mas usam o número de uma empresa legalizada que atua em outro ramo alimentício; lançam uma marca nova e inventam o número; ou copiam o rótulo e o número de um fabricante de queijo que ainda esteja no mercado ${ }^{10}$. 
Os queijos com carimbo falso, raramente são vendidos nas grandes redes de supermercados, e sim nos estabelecimentos menores que não exigem notas fiscais. $\mathrm{O}$ Ministério da Agricultura em São Paulo detectou entre junho de 1997 e julho de 1998, pelo menos 10 casos de fraude, a maioria nas regiões de Campinas Ribeirão Preto. A adulteração afetou, principalmente, queijos do tipo Minas, mussarela e ricota. O mesmo problema já foi constatado em outros pontos do país, como o Rio de Janeiro ${ }^{10}$.

Na zona leste de São Paulo, em uma chácara urbana, existe um curral com 70 cabeças de gado, sendo que 25 são vacas. Os proprietários vivem do comércio clandestino do leite, distribuído em favelas, e da fabricação de queijos. O leite é acondicionado em garrafas plásticas de refrigerantes, que são lavadas precariamente; a distribuição é feita em carroças sem refrigeração, e não há controle sanitário em nenhuma etapa do processo ${ }^{15}$.

A legislação brasileira autoriza o comércio de leite cru em apenas um caso: nos lugares que não recebem o produto beneficiado. Mesmo assim, a distribuição só pode ocorrer, se o leite vier de currais higiênicos e de vacas sadias, sujeitas periodicamente à avaliação veterinária do governo. Exige-se também, que seja engarrafado e vendido no prazo máximo de 3 horas após a ordenha ${ }^{13}$.

Entretanto, na Paraíba estima-se que apenas 10\% dos municípios fiscalizam o leite consumido pela população. Mais de $70 \%$ da população da Paraíba só tem acesso a leite in natura, que é vendido de casa em casa, em vacarias ou em pequenos pontos de distribuição. Os vendedores de leite in natura utilizam bicicletas, motocicletas e carros na distribuição do produto aos clientes nas grandes cidades do interior paraibano. Em cidades menores, o leite chega a ser transportado por jumentos $^{22}$.

Algumas indústrias de pasteurização já tentaram entrar no mercado de leite do interior paraibano, mas não obtiveram êxito. As indústrias não conseguiram mudar o hábito da população de consumir o que se conhece como "leite puro, gordo e forte", existindo uma grande resistência ao leite pasteurizado ${ }^{22,23}$. Acredita-se também, que o hábito de ferver o leite destrua vitaminas e torna insolúvel parte do cálcio e do 
fósforo, inviabilizando sua absorção pelo organismo ${ }^{12}$.

No Pará, mais de dois terços do leite produzido anualmente no Estado (aproximadamente 300 milhões de litros), chegam ao consumidor, sem passar por nenhum tipo de fiscalização. Em 1997, por exemplo, o governo federal fiscalizou apenas 26 milhões de litros. Os produtores preferem vender o leite aos distribuidores informais, porque os laticínios oferecem menos da metade do preço pago por eles ${ }^{150}$.

Em Minas Gerais, dos 6 bilhões de litros de leite produzidos anualmente no Estado, estima-se que cerca de 2.4 bilhões (40\%) são vendidos sem fiscalização. O Estado possui 137 cooperativas que industrializam o leite e é o maior produtor do país, respondendo por $30 \%$ da produção ${ }^{44}$.

A fama de "leite forte" atrai consumidores de leite in natura na cidade de São José da Lapa em Minas Gerais. Algumas das justificativas dadas por consumidores do "leite de curral" são: "o leite é mais gordo", ou "ele tem sabor e cheiro diferentes do industrializado, que é um leite fraco", ou ainda "é muito nais gostoso". O maior produtor de leite informal da cidade entrega o leite de porta em porta todas as manhãs e diz que as cooperativas "não oferecem um produto com a qualidade que as pessoas querem". Ele se orgulha de "não tirar nada do leite, de vendê-lo nas mesmas condições em que sai das tetas de suas 10 vacas". Para ele, isso dá o "sabor" especial $^{43}$.

No Paraná, o município de Cambé vai usar leite não pasteurizado, proveniente de 30 produtores, na merenda escolar da cidade. Apesar de o consumidor ser orientado a ferver o leite antes do consumo, uma veterinária do setor de Inspeção de Leite da Universidade Estadual de Londrina, acredita que essa medida põe em risco a saúde dos alunos e da população local ${ }^{185}$.

Na realidade, o que ocorre no Brasil é um fenômeno social complexo. Em geral, os leiteiros ignoram os riscos sanitários do produto que comercializam. São criadores modestos, não organizados e de baixa escolaridade, que burlam a lei para sobreviver. Se vendessem o leite às usinas, acabariam sendo inviabilizados comercialmente, porque ganhariam menos do que lucram com a venda ilegal. A 
maioria dos compradores também não dispõe de informações mais sofisticadas sobre segurança alimentar. Consomem o leite cru por julgá-lo mais saudável e ainda contam com a vantagem de o produtor informal vender fiado ${ }^{9}$.

As áreas do governo que deveriam orientar a população, dar assistência técnica aos leiteiros e fiscalizar o cumprimento da lei, reconhecem a gravidade do problema, mas freqüentemente se omitem, alegando falta de recursos financeiros ${ }^{9}$.

\subsection{4- CONTROLE DA TUBERCULOSE POR M.bovis NOS} ANIMAIS DOMÉSTICOS E SELVAGENS

A eliminação da tuberculose no bovino, sempre foi uma medida decisiva na luta contra a tuberculose causada pelo M.bovis no homem, mas desde que algumas espécies de animais selvagens, principalmente os texugos no Reino Unido e Irlanda, o gambá na Nova Zelândia e o antílope na Zâmbia, têm sido reconhecidas como reservatórios significativos do M.bovis, com auto-manutenção endêmica da infecção, estas espécies, além de outras domésticas e selvagens pelo mundo todo, constituem um grande obstáculo aos programas de controle da doença e impedem a sua completa erradicação na população bovina ${ }^{19,149,199,216}$.

Quando há interação entre infecção em animais selvagens e domésticos, a erradicação da doença torna-se impraticável ${ }^{61,199,216}$. Ou ainda, se uma espécie animal selvagem pode manter a infecção em uma área, na ausência de transmissão cruzada de outras espécies de animais domésticos e selvagens, a total eliminação da doença nessa população torna-se uma meta ilusória ${ }^{199}$.

A manutenção de hospedeiros selvagens é caracterizada pela sua habilidade em produzir, temporariamente, a distribuição contínua da infecção em sua própria população 199, 216. Programas para erradicação da tuberculose bovina têm sido realizados em muitos países, para reduzir a incidência da infecção por M.bovis em humanos. Entretanto, porque sinais clínicos da doença não são comuns em muitas espécies animais até que a doença esteja avançada, e porque testes diagnósticos são limitados, a detecção e controle da transmissão de fontes não bovinas são muito 
difíceis ${ }^{263}$.

É indiscutível que medidas de controle contra uma doença transmissível não podem ser totalmente efetivas, se todos os reservatórios do agente etiológico não forem erradicados ${ }^{68}$. Medidas de controle para animais domésticos e selvagens em zoológicos, usualmente envolvem a eliminação dos animais afetados ${ }^{115,199}$.

Entretanto, em relação aos texugos, não existem garantias de que a política da destruição indiscriminada da população desses animais resolva os problemas da tuberculose no bovino ${ }^{125,149,203,210 .}$

Na República da Irlanda, os texugos são espécies protegidas sob os termos do Wildlife Act de 1976, por serem considerados ecologicamente importantes, apesar de, aparentemente, serem responsáveis por cerca de 10.000 cabeças de gado tuberculina-positivos por ano. Na Grã-Bretanha, são protegidos legalmente desde 1973, dificultando o controle da doença nesses hospedeiros ${ }^{149,210,216 .}$

Para muitas doenças infecciosas, acredita-se que uma pequena densidade populacional de hospedeiros primários, abaixo da qual a doença não pode persistir, produz um foco para indicar medidas de controle. Por isso, um modelo matemático da doença, elaborado em 1985, sugeriu que a colocação de armadilhas a cada 3-4 anos, seriam suficientes para reduzir a densidade populacional de texugos a níveis bastante inferiores, assegurando a erradicação da infecção pelo M.bovis nesses animais ${ }^{47,216}$. Mas, estudos posteriores demonstraram que, com o passar do tempo, a área era sempre recolonizada por outros texugos ${ }^{210}$.

Estudos comportamentais têm sido realizados em uma população rural de texugos em Cork, na República da Irlanda, desde 1987. Os texugos são capturados sob licença, por meio de iscas de amendoim em armadilhas, e anestesiados. Cada animal é rotulado com etiquetas plásticas na orelha, seu peso verificado e classificado pelo sexo. Amostras de fezes, sangue e, ocasionalmente, urina são colhidas para exames laboratoriais para evidenciar infecção pelo M.bovis ${ }^{216}$. Alguns texugos são etiquetados com rádio-transmissor e seu percurso tem fornecido informações sobre os movimentos desses animais, individualmente ${ }^{47,216}$. Tem sido constatado, que na 
população rural de texugos, tanto as fêmeas como os machos percorrem longas distâncias, algumas vezes fora de seu grupo territorial ${ }^{216}$.

No Wildlife Park de Doneraile, County Cork, três tipos de cercas elétricas foram avaliadas quanto à sua efetividade no controle dos movimentos dos texugos. $\mathrm{O}$ uso de arame farpado eletrificado com alta tensão foi o mais bem-sucedido e, apesar de caro, foi considerado a melhor opção para fazendeiros que possuem médios ou grandes rebanhos leiteiros e que desejam cercar as divisas de suas fazendas para prevenir o acesso de texugos ${ }^{216}$.

$\mathrm{Na}$ Grã-Bretanha, o controle de texugos por envenenamento de seus setts subterrâneos, com o bombeamento do gás cianeto de hidrogênio, para prevenir a transmissão da infecção por M.bovis entre texugos e bovinos, começou em agosto de 1975. A decisão para iniciar um programa de controle de texugos foi tomada, quando houve o reconhecimento de que texugos infectados com M.bovis poderiam desenvolver tuberculose clínica e eram uma potencial fonte de contaminação para as pastagens utilizadas pelo gado, e quando houve a associação entre infecção nos texugos e a ocorrência de bovinos reatores à tuberculina 63, 64, 68, 180, 203, 216, 279, 286. Vários protestos de conservacionistas foram gerados, afirmando que a técnica de envenenamento era desumana e ineficaz e levando a uma suspensão do método, em junho de $1982^{64,68,125,147,216,278,279 .}$

O controle foi novamente restabelecido em agosto de 1982, na região sudoeste da Inglaterra, onde havia evidências de que o gado tinha sido infectado por texugos tuberculosos $25,64,68,125,216,278$. Um total de 167 áreas semelhantes, com um tamanho médio de $7 \mathrm{~km}^{2}$, foram envenenadas ${ }^{216,279}$. O número observado de rebanhos de bovinos reatores à tuberculina, subseqüentemente ao ano do envenenamento (final de 1983), foi 320 rebanhos menos que o esperado, representando uma redução proporcional de $44,4 \%{ }^{216}$. A eficiência deste método foi de, aproximadamente, $90 \%{ }^{279}$.

Entretanto, foi substituído pela estratégia de captura dos texugos em áreas com surtos de tuberculose bovina, denominada "clean ring", por meio de armadilhas colocadas ao redor dos setts, sendo que todos eles eram mortos com um tiro, com 
exceção das fêmeas lactantes que eram liberadas, até que um anel livre de infecção fosse estabelecido ${ }^{147,279}$. O tamanho da área coberta por cada operação de controle, era de aproximadamente $7 \mathrm{~km}^{2}$ (a mesma para a campanha do gás) e sua eficiência foi de aproximadamente $80 \%$; mas a opinião pública também era contra ${ }^{147,278,279}$.

Em abril de 1986, foi introduzida outra estratégia, denominada "interim strategy" que permaneceu em vigor até 1994, e que consistia em operações de captura dos texugos, apenas nos locais de uma fazenda onde se acreditava que o gado havia contraído a doença desses animais, ou em toda a fazenda, se não havia a possibilidade dessa precisão. A área coberta por cada operação de controle, era de aproximadamente $1 \mathrm{~km}^{2}$. Todos os texugos capturados, com exceção das fêmeas lactantes, eram mortos e submetidos a exames post mortem ${ }^{147,278,279}$. A eficiência deste método ficou em torno de $70 \%{ }^{279}$. Esse método falhou porque os texugos eram removidos apenas se entrassem na área da fazenda onde havia ocorrido um surto, portanto, animais de outras áreas poderiam entrar na fazenda, e recolonizar os setts $^{147}$.

Uma nova estratégia, anunciada pelo MAFF em 1993, foi introduzida em novembro de 1994, e consistia basicamente na mesma estratégia anterior ("interim strategy"), mas aplicada em áreas do sudoeste da Inglaterra que não apresentavam uma história de tuberculose bovina no gado. Entretanto, nas fazendas onde havia ocorrido surtos de tuberculose, suspeitos de serem originários de texugos, três alternativas eram aplicadas. Na primeira, operações de controle só eram conduzidas se o proprietário da fazenda concordasse, a não ser que houvesse um surto subsequente de tuberculose no gado. Na segunda alternativa, a estratégia era a “interim strategy”, introduzida em 1986. E na terceira, a mesma estratégia seria conduzida, mas adicionada de um teste sangüíneo para o diagnóstico de tuberculose nos texugos, denominado "live test", que seria usado em todos os setts existentes, em um raio de aproximadamente $10 \mathrm{~km}^{2}$, para constatar se algum texugo também estava infectado com tuberculose bovina ${ }^{279}$.

O "live test" produziu uma pequena proporção de falso-positivos (90\% de especificidade), mas uma grande proporção de falso-negativos (41\% de 
sensibilidade). A sensibilidade também foi afetada pelo estado de infectividade do texugo. Para animais infecciosos, a sensibilidade foi de $62,0 \%$, e para os infectados, mas não contagiosos, de $36,6 \%{ }^{279}$.

Como o teste não pôde ser usado para detectar a infecção em animais individualmente, que era a intenção original, ele foi usado para identificar quais os setts continham texugos positivos ao teste. Todos os animais capturados na primeira semana foram testados e se um animal fosse encontrado infectado, a captura continuava naquele sett por mais 3 semanas, com o objetivo de apreender pelo menos 90\% de todos os texugos do sett positivo. Todos os texugos capturados, com exceção de fêmeas lactantes, foram mortos. Sua eficiência foi de aproximadamente 70$80 \%{ }^{279}$.

Clifton-Hadley e col. (1995) ${ }^{63}$, no período de 1966-92, realizaram um estudo no sudoeste da Inglaterra e concluíram que a erradicação da tuberculose nas populações de texugos de uma área definida, na qual ocorria tuberculose no bovino, resolvia a incidência da infecção por M.bovis no gado, por no mínimo 10 anos, se a ação de controle fosse radical e se providências fossem tomadas para impedir a recolonização da área por outros texugos, durante vários anos ${ }^{63}$.

Entretanto, no final de 1993, o MAFF havia empreendido 1.096 operações de controle de texugos (sendo 42 só no sudoeste da Inglaterra), e observou que apesar de algum sucesso local, não houve um declínio na incidência da tuberculose bovina no gado e a doença ainda estava confinada nas mesmas áreas ${ }^{278,279}$. Porém, desde 1996, intervenções envolvendo a remoção de texugos das áreas que apresentavam persistentes problemas de tuberculose pelo M.bovis, resultaram no declínio das taxas de infecção no gado, quando nenhuma outra espécie de animal selvagem estava envolvida ${ }^{64}$.

Desde que se comprovou que os texugos são importantes reservatórios de M.bovis, qualquer política de erradicação da tuberculose no bovino deve levar em consideração a ocorrência do M.bovis em texugos ${ }^{149}$.

Para animais como o gambá, na Nova Zelândia, onde é reconhecido como 
uma espécie pestilenta por razões que vão além da transmissão da tuberculose, acredita-se também que um misto de medidas para controle da população poderia oferecer vantagens sobre apenas o envenenamento da área ${ }^{149,199,216 .}$

A erradicação da tuberculose no bovino pelo controle da população local de gambás, em conjunção com o teste tuberculínico e abate dos bovinos reatores, começou em $1972{ }^{65}$. Desde então, gambás infectados por M.bovis foram controlados por meio de envenenamento em massa, com iscas contendo o veneno 1080 (Monofluoroacetato de sódio) utilizado por ser efetivo, relativamente seguro e rapidamente degradado no meio ambiente. Entretanto, seu custo tornou-se proibitivo ao longo dos anos 24, 63, 199, 216, 269 .

Outros mecanismos que estão em estudo são: o controle de fertilidade em adultos de um ou ambos os sexos, medidas para reduzir a dispersão de animais jovens infectados e o uso de fontes de veneno de acesso contínuo. No entanto, todas essas medidas requerem maiores investimentos em pesquisas e, provavelmente, não produzirão bons resultados em menos de 10 anos. Ao mesmo tempo, acumulam-se evidências de que existe a possibilidade da redução da infecção por M.bovis entre animais selvagens e animais domésticos, por meio de programas de controle aplicados nas fazendas. Estes programas locais poderiam ser montados, visando um efetivo controle da doença nos animais de criação, pelo uso de procedimentos de manuseio, cuidadosamente acompanhados no tempo, cujo objetivo seria o de minimizar interações comportamentais, que poderiam facilitar a transmissão da infecção entre estes animais e os selvagens ${ }^{199,216}$.

Na Nova Zelândia, durante a década de 80 , houve uma redução nos recursos financeiros empregados no controle dos gambás, e a incidência de tuberculose no gado aumentou. Em 1990, mantendo-se o mesmo nível de gasto anterior, o número de reservatórios selvagens infectados aumentou de 10 para $22 \%{ }^{24}$.

Mais recentemente, na Nova Zelândia começaram a ser desenvolvidos modelos matemáticos que têm desempenhado um importante papel nas políticas de controle da tuberculose bovina no país, baseados em sistemas de informação geográfica 24, 246, 269. Estes sistemas fornecem a situação da doença no país, 
monitorando os efeitos dos programas de controle por meio de mapas que descrevem o passado, o presente e o futuro simulado da doença, por regiões, através de análises descritivas e quantitativas das dinâmicas espaciais e temporais da propagação da infecção, na população de gambás e bovinos ${ }^{246}$.

Estes mapas de distribuição identificam as áreas de risco para o país, ao localizarem as habitações dos gambás e as fazendas da região, além de calcularem a densidade populacional de gambás e bovinos nas diferentes áreas geográficas ${ }^{246}$.

Através desses modelos matemáticos, estuda-se a possibilidade da doença ser eliminada do principal vetor selvagem, que é o gambá, por meio de estratégias de controle mais aperfeiçoadas, que estão sendo implementadas. Eles também são usados, para avaliar o provável sucesso de futuras opções de controle para os gambás, como a vacinação contra a tuberculose e a imunocontracepção, e de diferentes políticas de testes tuberculínicos e restrição de movimentos para rebanhos de bovinos 24 .

O planejamento no tempo dessas várias medidas deve tornar-se tão importante quanto a natureza das medidas tomadas. Entretanto, ainda não foram empregadas políticas de controle que não sejam a simples redução da população de gambás, pois acredita-se que se a transmissão da doença de animais selvagens para o bovino realmente ocorre, somente a total exterminação do animal responsável poderia ser efetiva e possível ${ }^{68,216}$.

Portanto, o desenvolvimento de estratégias melhores e mais custo-efetivas para o controle da tuberculose em ambos, gambás e bovinos, dependem de um melhor conhecimento a respeito de gambás infectados, métodos de propagação da infecção dentro das populações de gambás e a sua transmissão ao gado ${ }^{216}$.

Em vista do aumento no número de rebanhos de cervídeos domesticados em vários países, e a evidência da propagação do M.bovis do animal para o homem, bem como de animal para animal, existe a necessidade de desenvolvimento de medidas de controle para a industrialização de cervídeos, com a finalidade de reduzir a um risco mínimo a infecção humana. Pessoas de risco são os manipuladores de animais 
doentes e de carcaças, portanto, programas de proteção e acompanhamento regular desses trabalhadores são essenciais, até que a doença seja erradicada desta população animal $^{61,108,216}$.

Apesar da tuberculose por M.bovis em cervos de criação ser de mais difícil controle, devido a aparente alta transmissibilidade da doença entre esses animais na ausência de um reservatório selvagem, um teste tuberculínico confiável (associado a outras medidas como quarentena e cuidados no manuseio) e o abate de animais infectados em intervalos freqüentes, poderia eliminar a infecção da maioria dos rebanhos de cervídeos ${ }^{61,70,216,259,302}$.

Em suínos, algumas medidas de controle são: o cozimento de restos de restaurantes antes de alimentar os animais, abate dos suínos positivos ao teste da tuberculina, desinfecção das baias com desinfetantes fenólicos e troca do material da cama (serragem ou maravalha) ${ }^{215}$.

A prevenção e controle da infecção por M.bovis em animais exóticos adquiridos por zoológicos, parques animais ou colonias de primatas, são feitos pela aquisição de animais provenientes de rebanhos conhecidamente livres da doença e a aplicação de quarentena nos animais importados. O teste da tuberculina deve ser realizado nos primatas não humanos, em intervalos de 14 a 30 dias, e quando a tuberculose for diagnosticada, torna-se necessária a morte dos animais tuberculinapositivos e a limpeza e desinfecção dos locais habitados por eles. A desinfecção deve ser feita em 3 vezes e em intervalos de 14 a 21 dias ${ }^{96,261}$. 


\section{6- COMENTÁRIOS FINAIS}

Além da declaração feita pela Organização Mundial da Saúde em 1995, colocando a tuberculose em "estado de emergência" em todo o mundo, a preocupação desta instituição em relação à considerável e contínua importância em saúde pública da infecção pelo M.bovis no ser humano e animais, alertaram para a ameaça que a tuberculose representa atualmente para países desenvolvidos e em desenvolvimento.

O M.bovis é o agente etiológico da tuberculose bovina e possui uma das mais amplas cadeias de hospedeiros entre todos os patógenos conhecidos, sendo tão patogênico para o homem, como o M.tuberculosis. Portanto, diversas espécies mamíferas, incluindo o homem são susceptíveis ao bacilo bovino. $\mathrm{O}$ homem pode contrair a doença de diferentes animais e igualmente transmitir-lhes a infecção.

A tuberculose bovina é uma zoonose de distribuição mundial, com alta prevalência nos países em desenvolvimento e baixa nos desenvolvidos, devido a programas de controle e errradicação que envolvem o teste tuberculínico e o abate dos bovinos tuberculina-positivos, a inspeção de carnes e a pasteurização do leite. Essa zoonose ocasiona grandes prejuízos à economia de um país, vitimando o gado, diminuindo progressivamente sua capacidade produtiva e representando uma ameaça para a saúde humana.

Há uma notável falta de informações, no Brasil e nos Trópicos, a respeito da prevalência da tuberculose causada por M.bovis no homem e no bovino, mas relatos disponíveis sugerem que em 69\% dos países tropicais, existem significantes níveis de tuberculose bovina no gado e que, aproximadamente, $10 \%$ dos casos de tuberculose clínica em humanos, são causados pelo M.bovis, nos países em desenvolvimento. Nos países desenvolvidos, a prevalência da tuberculose humana por esse agente, varia de $0,1 \%$ na França a $5 \%$ no Reino Unido.

Há uma grande preocupação de que a pandemia HIV/AIDS aumente o número de casos de tuberculose humana causada por M.bovis, a exemplo do que ocorreu nos casos de tuberculose humana por M.tuberculosis. Este fato acarretaria 
também um aumento no grau de transmissão da infecção para outros seres humanos e animais domésticos ou de criação, e favoreceria a transmissão inter-humana do M.bovis, fazendo com que esse tipo de transmissão se torne predominante, no futuro, quando o tempo eliminar os casos de tuberculose resultantes da reativação endógena.

Não é possível observar diretamente em populações humanas, a prevalência da infecção pelo M.bovis, uma vez que nem o teste tuberculínico, e nem qualquer outro método de investigação populacional pode distinguir essa infecção daquela causada pelo M.tuberculosis. Laboratorialmente, devido à aparente similaridade na apresentação clínica, tratamento e prognóstico da infecção no homem pelo M.bovis e M.tuberculosis, sempre houve falhas na diferenciação entre estas micobactérias, em muitos países no mundo, não permitindo que novos casos fossem diagnosticados, principalmente naqueles onde se julgava erradicada a tuberculose bovina.

A falha na distinção desses bacilos induziu à falsa impressão que, medidas de controle, para os bovinos, fossem suficientes para se considerar a doença humana por M.bovis quase extinta em muitos países desenvolvidos.

Apesar do desenvolvimento de novas técnicas diagnósticas, o exame bacteriológico (baciloscopia e cultura) ainda é o padrão ouro para o isolamento do M.bovis e posterior identificação do bacilo pelos testes bioquímicos.

As novas técnicas de biologia molecular, apesar de constituirem um grande avanço tecnológico, ainda necessitam de maiores avaliações de sua sensibilidade e especificidade, principalmente porque, até o momento, nenhuma sequência única de DNA, para o M.bovis, foi encontrada.

No passado, dava-se pouca importância aos reservatórios animais domésticos e selvagens, como fontes de infecção pelo M.bovis, mas a gradual eliminação da tuberculose nos bovinos veio ressaltar o perigo que esses reservatórios representam, uma vez que animais selvagens infectados são responsáveis, no presente, por casos esporádicos de tuberculose bovina.

Portanto, desde que os texugos e gambás foram considerados os principais reservatórios endêmicos da infecção, assim como hospedeiros ideais para a 
manutenção do M.bovis, entre a população de animais selvagens (além de cervídeos e de uma infinidade de hospedeiros animais, inclusive os domésticos e cativos em zoológicos e parques animais, no mundo todo), qualquer política de erradicação da tuberculose no gado, deverá levar em consideração a ocorrência do M.bovis nesses animais, principalmente porque vacinas eficazes ainda não foram desenvolvidas e a quimioterapia não é recomendada para animais.

Apesar dos animais selvagens não serem de importância epidemiológica na transmissão da infecção pelo M.bovis, no Brasil, a luta que países como a GrãBretanha, República da Irlanda e Nova Zelândia vêm empreendendo no combate à essas fontes de infecção, servem como exemplo e um alerta às autoridades sanitárias brasileiras, para que se empenhem no combate à tuberculose bovina no gado, para evitar que, futuramente, esses reservatórios pertençam à cadeia epidemiológica da doença.

A eliminação da tuberculose no bovino, sempre foi uma medida decisiva na luta contra a tuberculose causada pelo M.bovis no homem, mas com a atual interação entre infecção em animais selvagens e domésticos, a erradicação da doença torna-se impraticável, uma vez que ela só é alcançada quando existe a aplicação simultânea de medidas de combate às fontes de infecção, aos animais susceptíveis e às vias de transmissão. Por isso, se uma espécie animal selvagem mantiver a infecção em uma área, na ausência de transmissão cruzada de outras espécies de animais domésticos e selvagens, a total eliminação da doença, nessa população, tornar-se-á uma meta ilusória, pois eles induzirão a distribuição contínua da infecção em sua própria população.

Devido à onipresença do M.bovis em tantos hospedeiros, deve-se pensar seriamente na possibilidade do M.bovis, futuramente, tornar-se endêmico, decorrente de uma mudança gradual no espectro de hospedeiros selvagens em diferentes partes do mundo, diminuindo as perspectivas de eliminação da infecção dessas espécies, e perpetuando os ciclos de transmissão da doença entre a população de animais domésticos e selvagens, o bovino e o homem, impedindo que a tuberculose bovina seja controlada e sejam atingidos os objetivos de erradicação da doença no bovino. 
Como os animais selvagens estão reintroduzindo a tuberculose em rebanhos livres, fazendo a tuberculose bovina ressurgir após a sua erradicação, em certas áreas, nos países desenvolvidos, sendo responsáveis por casos esporádicos ou surtos epidêmicos de tuberculose bovina, a efetiva colaboração entre os microbiologistas médicos e veterinários e profissionais de saúde pública, será essencial na investigação da importância zoonótica do M.bovis, futuramente.

Uma das questões ainda não respondidas, entre as várias formuladas recentemente, a respeito da transmissão inter-humana da infecção por M.bovis é que, se esse tipo de transmissão realmente ocorre, a possibilidade desta forma de tuberculose persistir na população humana na ausência de um reservatório animal da doença, seria viável. A transmissão humano-para-humano da tuberculose causada pelo M.bovis em pessoas HIV-positivas, já é confirmada. A possibilidade de que a infecção pelo HIV seja capaz de induzir a perpetuação dos ciclos de transmissão animal-para-humano, humano-para-humano e humano-para-animal, requer considerações cuidadosas.

Avanços no diagnóstico, no sentido de discriminar as cepas de M.bovis e M.tuberculosis, tornam-se necessários, uma vez que um diagnóstico falho produz falhas nos dados epidemiológicos referentes à prevalência da infecção por M.bovis no homem e no animal, e consequentemente, falhas no tratamento.

Apesar das técnicas de biologia molecular não estarem totalmente desenvolvidas, elas foram utilizadas, recentemente, na elucidação de dois surtos epidêmicos nosocomiais, devidos à transmissão inter-humana de cepas micobacterianas multidroga-resistentes, entre pacientes HIV-positivos em um hospital na França, descrito por Bouvet e col. em 1993, e em outro hospital na Espanha, descrito por Blásquez e col. em 1997.

No surto da França, as cepas foram identificadas bioquimicamente como sendo de M.bovis e no surto da Espanha, suspeitou-se que as cepas eram M.tuberculosis. Entretanto, análises posteriores realizadas por técnicas de biologia molecular, identificaram as cepas da França como sendo M.tuberculosis, e as da Espanha, como sendo M.bovis. 


\section{Será que no futuro, as provas de biologia molecular conseguirão demonstrar que os testes bioquímicos atuais para tipificação do complexo M.tuberculosis são falhos, e que muitos casos de cepas identificadas como M.bovis eram na realidade M.tuberculosis e vice-versa? Se isto realmente ocorrer, haverá uma revolução no estudo epidemiológico das tuberculoses humana e bovina.}

Desde que a pirazinamida passou a ser regularmente usada como uma droga antituberculosa de $1^{\mathrm{a}}$ linha, e cepas de M.bovis são naturalmente resistentes a essa droga, o perigo do desenvolvimento de cepas multidrogas-resistentes por tratamento inadequado ou incompleto (uma vez que exigem terapia prolongada e aumentam o período de comunicabilidade entre os doentes), poderá tornar a tuberculose humana por M.tuberculosis e M.bovis, incurável no futuro.

A erradicação da tuberculose bovina deve ser perseguida, uma vez que, atuais modismos, como o consumo de leite cru, voltam a despertar o interesse de pessoas no mundo todo.

No Brasil, o comércio clandestino envolvendo a compra e venda de bovinos tuberculosos, laticínios contaminados, fabricação de carimbos da inspeção sanitária e currais escondidos nas periferias das metrópoles, aliado à falta de dados estatísticos confiáveis sobre a realidade da tuberculose bovina no país, constituem uma grande ameaça à saúde pública.

É extremamente preocupante o fato de que $41 \%$ do leite bovino que se produziu no país em 1997 tinham origem clandestina, sem o aval da inspeção sanitária e que os brasileiros consumiram esse leite também na forma de queijos, iogurtes e bebidas lácteas, cujos fabricantes falsificavam carimbos dos serviços de inspeção federal, estadual ou municipal, vendendo esses produtos em estabelecimentos que não exigiam nota fiscal, colocando em risco a saúde do consumidor. Alegando falta de recursos financeiros, as autoridades competentes que deveriam orientar a população, prestarem assistência técnica aos produtores e fiscalizar o cumprimento da lei, frequëntemente se omitem, apesar de reconhecerem a gravidade do problema. 
Finalizando, essa revisão evidencia a importância zoonótica, em saúde pública, do M.bovis na tuberculose humana e animal causada por esse agente, principalmente após a reintrodução da tuberculose bovina pelos animais selvagens, nos países onde ela estava praticamente erradicada, e reforça a necessidade de concretização das recomendações da OMS, divulgadas em Genebra em 1993, as quais somente serão possíveis, mediante uma política de aporte de recursos materiais, humanos e financeiros que envolvam uma cooperação internacional de órgãos vinculados à saúde pública. 


\section{7- REFERÊNCIAS BIBLIOGRÁFICAS}

1- AlBRECHT, H.; STELlbRINK, H.J.; EGGERS, C. et al. A case Of disseminated Mycobacterium bovis infection in an AIDS patient. Eur. J. Clin. Microbiol. Infect. Dis., 14: 226-9, 1995.

2- ALHAJI, I. Bovine tuberculosis: a general review with special reference to Nigeria. Vet. Bull., 46: 829-37, 1976.

3- ALMEIDA, A.P. \& MAGARÃO, M.F. Situação do problema da tuberculose no Brasil. Rev. Serv. Nac. Tuberc., 13(51): 219-34, 1969.

4- ANDRADE, G.B.; RIET-CORREA, F.R.; MIELKE, P.V. et al. Estudo histológico e isolamento de micobactérias de lesões similares à tuberculose em bovinos no Rio Grande do Sul. Pesq. Vet. Bras., 11(3/4): 81-6, 1991.

5- ANDRADE, L.; SANTIAGO, A.C.; ANDRADE, E.M. Caso de tuberculose pulmonar por bacilo bovino na Guanabara. Rev. Div. Nac. Tuberc., 16(63): 372-90, 1972.

6- ANDRADE, L.E.C. Princípios de biologia molecular e suas aplicações em medicina. Rev. Assoc. Med. Bras., 39: 175-86, 1993.

7- ANDROSOVA, M.V.; VLADIMIRSKY, M.A.; VASILENKOVA, O.V. et al. Enzyme linked immunosorbent assay for identification of whole Mycobacterium bovis isolates with the monoclonal antibodies. Tuber. Lung Dis., 77: 348-352, 1996.

8- ANERIK, A.I. Estudio experimental sobre el diagnóstico de la tuberculosis bovina mediante pruebas de cultivo e inoculación animal. Cienc. Vet., Maracaibo, 4: 137-200, 1974.

\footnotetext{
*De acordo com:

UNIVERSIDADE DE SÃO PAULO. Faculdade de Saúde Pública. Serviço de Biblioteca e Documentação. Normas de referências bibliográficas aplicadas à saúde pública. São Paulo, 1990.
} 
9- ANTENORE, A. $41 \%$ da produção de leite é clandestina. Folha de São Paulo, São Paulo, 30 ago. 1998. Cad.3, p.1.

10- ANTENORE, A. Fabricantes de queijo fraudam certificado. Folha de São Paulo, São Paulo, 30 ago. 1998. Cad.3, p.4.

11- ANTENORE, A. Governo admite comércio de gado com tuberculose no país. Folha de São Paulo, São Paulo, 30 ago. 1998. Cad.3, p.4.

12- ANTENORE, A. Hábito de ferver destrói vitamina. Folha de São Paulo, São Paulo, 30 ago. 1998. Cad.3, p.2.

13- ANTENORE, A. Lei autoriza leite cru em um caso. Folha de São Paulo, São Paulo, 30 ago. 1998. Cad.3, p.2.

14- ANTENORE, A. Leite clandestino pode provocar tuberculose. Folha de São Paulo, São Paulo, 30 ago. 1998. Cad.3, p.2.

15- ANTENORE, A. Zona leste esconde curral de 70 cabeças. Folha de São Paulo, São Paulo, 30 ago. 1998. Cad.3, p.3.

16- ANTONUCCI, G.; GIRARD, E.; RAVIGLIONE, M.C. et al. Risk factors for tuberculosis in HIV-infected persons: a prospective cohort study. JAMA, 274: 143-8, 1995.

17- ARANAZ, A.; LIÉBANA, E.; MATEOS, A. et al. Spacer oligonucleotide typing of Mycobacterium bovis strains from cattle and other animals: a tool for studying epidemiology of tuberculosis. J. Clin. Microbiol., 34: 2734-40, 1996.

18- ARAÚJO, F.L. \& TURNES, C.G. Prevalência de brucelose, tuberculose e mastite subclínica nos rebanhos leiteiros de Cáceres, Mirassol D’oeste e Araputanga, Mato Grosso. In: Congresso Brasileiro de Medicina Veterinária, $16^{\circ}$, Salvador, BA, 1978. Anais Salvador, BA, Sociedade Brasileira de Medicina Veterinária, 1978. p.17. 
19- BADALÍK, L.; HONZÁTKOVÁ, Z.; KRISTÚFEK, P. et al. Surveillance of tuberculosis caused by Mycobacterium bovis in Slovakia. J. R. Soc. Health, 115: 310-3, 1995.

20- BAKUNZI, F.R.; ZYAMBO, G.C.N.; MORRIS, S. Bovine tuberculosis survey in the Molopo district of the North West Province. Tydskr. S. Afr. Vet. Ver., 66: 28-9, 1995.

21- BALIAN, S.C.; RIBEIRO, P.; VASCONCELLOS, S.A. et al. Linfadenites tuberculóides em suínos abatidos no Estado de São Paulo, Brasil: aspectos macroscópicos histopatológicos e pesquisa de micobactérias. Rev. Saúde Pública, 31: 391-7, 1997.

22- BARBOSA, A. Paraíba fiscaliza só $10 \%$ do que consome. Folha de São Paulo, São Paulo, 30 ago. 1998. Cad.3, p.7.

23- BARBOSA, A. População evita pasteurizado. Folha de São Paulo, São Paulo, 30 ago. 1998. Cad.3, p.7.

24- BARLOW, N.D. Bovine tuberculosis in New Zealand: epidemiology and models. Trends Microbiol., 2: 119-24, 1994.

25- BARROW, P.A. \& GALLAGHER, J. Aspects of the epidemiology of bovine tuberculosis in badgers and cattle. I. The prevalence of infection in two wild animal populations in south-west England. J. Hyg., Lond., 86: 237-45, 1981.

26- BARROW, P.A. Aspects of the epidemiology of bovine tuberculosis in badgers and cattle. II. The development and use of a typing system for Mycobacterium bovis. J. Hyg.; Lond., 86: 247-57, 1981.

27-BARRY, T.; GLENNON, M.; SMITH, T. et al. Detection of Mycobacterium bovis in bovine blood by combined PCR and DNA probe methods. Vet. Rec., 132: 66-7, 1993. 
28-BARUSELLI, P.S.; OLIVEIRA, J.F.S.; MENDES, M.L.M. et al. Diagnóstico da bubalinocultura do Vale do Ribeira. Campinas, 1993. (Documento Técnico CATI, 94).

29- BASILE, B.H.; BALARIN, O.F.; BALARIN, M.R.S. et al. Tuberculose genital em vaca Nelore (Bos indicus), relato de um caso. Semina, 6: 2-4, 1985.

30- BENGIS, R.G.; KRIEK, N.P.J.; KEET, D.F. et al. An outbreak of bovine tuberculosis in a free-living African buffalo (Syncerus caffer - Sparrman) population in the Kruger National Park: a preliminary report. Onderstepoort J. Vet. Res., 63: 15-8, 1996.

31- BENHAM, P.F.J. \& BROOM, D.M. Responses of dairy cows to badger urine and faeces on pasture with reference to bovine tuberculosis transmission. Br. Vet. J., 147: 517-33, 1991.

32- BERGEY'S manual of systematic bacteriology. Edited by Sneath, P.H.A. et al., Williams \& Wilkins, Baltimore, 1986. v.2, sec.16, p.1435-57.

33- BHAT, G.J.; DIWAN,V.K.; CHINTU, C. et al. HIV, BCG and TB in children: a case control study in Lusaka, Zambia. J. Trop. Pediatr., 39: 219-23, 1993.

34- BIER, O. Bacteriologia e imunologia. $19^{\mathrm{a}}$ ed. São Paulo, Edições Melhoramentos, 1978. p.585-610: Micobactérias.

35- BLANCOU, J. \& CHENEAU, Y. Recherche du bacille de Koch dans le sang et les muscles de bovins tuberculeux. Rev. Elev. Mèd. Vét. Pays Trop., 29: 11-5, 1976 .

36- BLÁZQUEZ, J.; LOS MONTEROS, L.E.E. de; SAMPER, S. et al Genetic characterization of Multidrug-Resistant Mycobacterium bovis strains from a hospital outbreak involving human immunodeficiency virus-positive patients. J.Clin.Microbiol., 35: 1390-3, 1997.

37- BLOOD, D.C. \& HENDERSON, J.A. Clínica veterinária. $7^{\mathrm{a}}$ ed. Rio de Janeiro, Guanabara Koogan, 1993. 
38- BLUNDEN, A.S. \& SMITH, K.C. A pathological study of a mycobacterial infection in a cat caused by a variant with cultural characteristics between Mycobacterium tuberculosis and M.bovis. Vet. Rec., 27: 87-8, 1996.

39- BOLLA, G.J. de. Tuberculosis in a cat. [Letter] Vet. Rec., 134: 336, 1994.

40- BÖLSKE, G.; ENGLUND, L.; WAHLSTRÖM, H. et al. Bovine tuberculosis in Swedish deer farms: epidemiological investigations and tracing using restriction fragment analysis. Vet. Rec., 136: 414-7, 1995.

41- BOUVET, E.; CASALINO, E.; MENDOZA-SASSI, G. et al. A nosocomial outbreak of multidrug-resistant Mycobacterium bovis among HIV-infected patients: a case-control study. AIDS, 7(11): 1453-60, 1993.

42- BOVINE tuberculosis: Pennsylvania. Morb. Mortal. Wkly. Resp., 39(12): 201-3, 1990.

43- BRAGON, R. Fama de leite "forte" atrai em Minas Gerais. Folha de São Paulo, São Paulo, 30 ago. 1998. Cad.3, p.6.

44- BRAGON, R. MG não fiscaliza 40\% do leite. Folha de São Paulo, São Paulo, 30 ago. 1998. Cad.3, p.6.

45- BRETT, J.L. \& HUMBLE, M.W. Incidence of human tuberculosis caused by Mycobacterium bovis. N. Z. Med. J., 104(904): 13-4, 1991.

46- BROD, C.S.; MARTINS; L.F.S.; ARANALDE, A. A. et al. Prevalência da tuberculose bovina In: Encontro de Pesquisa Veterinária, $1^{\circ}$, Pelotas, RS, 1976. Anais. Pelotas, RS, Sociedade Brasileira de Medicina Veterinária, 1976. p.39.

47- BROWN, J.A.; HARRIS, S.; WHITE, P.C.L. Persistence of Mycobacterium bovis in cattle. Trends Microbiol., 2(2): 43-6, 1994.

48- BRUNINI SOBRINHO, R. Tuberculose no homem e nos animais. Casa Agric., 10(2): 17-8, 1988. 
49- CAFFREY, J.P. Status of bovine tuberculosis eradication programmes in Europe. Vet. Microbiol., 40: 1-4, 1994.

50- CALERO, J.R. Incremento de la tuberculosis y coinfeccion con el SIDA. An. $R$. Acad. Nac. Med. Madr., 12: 21-42, 1995.

51- CANOLA, J.C.; MARQUES,L.C. Tuberculose bovina: o raio x como meio auxiliar do diagnóstico. In: Encontro de Pesquisas Veterinárias, $13^{\circ}$, Jaboticabal, São Paulo, 1989. Resumos dos trabalhos. Jaboticabal, UNESP, 1989. p.109.

52- CENTRO PANAMERICANO DE ZOONOSIS. Metodos de laboratorio de micobacteriologia veterinaria para el aislamento $e$ identificacion de micobacterias. Ramos Mejia, Buenos Aires, 1973. (Serie de Monografias Cientificas y Tecnicas, C.P.Z., 6).

53-CENTRO PANAMERICANO DE ZOONOSIS Bacteriologia de la tuberculosis humana y animal. Ramos Mejia, Buenos Aires, 1979. (Serie de Monografias Cientificas y Tecnicas, C.P.Z., 11).

54- CENTRO PANAMERICANO DE ZOONOSIS Programas de control $y$ erradicación de la tuberculosis bovina. Ramos Mejia, Buenos Aires, 1983. (Publicación Especial, 4).

55- CENTRO PANAMERICANO DE ZOONOSIS. Situación de la tuberculosis bovina en América Latina y el Caribe. Buenos Aires, 1988. (Publicación Especial, 8).

56- CENTRO PANAMERICANO DE ZOONOSIS. Guia para proyetos de tuberculosis bovina. Buenos Aires, 1989. ( Nota Técnica, 15. rev. 1 ).

57- CHALMERS, J.W.T.; JAMIESON, A.F.; RAFFERTY, P. An outbreak of bovine tuberculosis in two herds in south west Scotland: veterinary and human public health response. J. Public Health Med., 18: 54-8, 1996. 
58- CHEESEMAN, C.L.; WILESMITH, J.W.; STUART, F.A. Tuberculosis: the disease and its epidemiology in the badger, a review. Epidemiol. Infect., 103: 113-25, 1989.

59- CLANCEY, J.K. The incidence of tuberculosis in lechwe (Marsh antelope). Tubercle, 58: 151-6, 1977.

60- ClERCX, C.; COIGNOUL, F.; JAKOVLJEVIC, S. et al. Tuberculosis in dogs. A case report and review of the literature. J. Am. Anim. Hosp. Assoc., 28: 207-11, 1992.

61- CLIFTON-HADLEY, R.S. \& WILESMITH, J.W. Tuberculosis in deer: a review. Vet. Rec., 129: 5-12, 1991.

62-CLIFTON-HADLEY, R.S.; WILESMITH, J.W.; STUART, F.A. Mycobacterium bovis in the European badger (Meles meles): epidemiological findings in tuberculous badgers from a naturally infected population. Epidemiol. Infect., 111: 9-19, 1993.

63- CLIFTON-HADLEY, R. S.; WILESMITH, J. W.; RICHARDS, M.S. et al. The occurrence of Mycobacterium bovis infection in cattle in and around an area subject to extensive badger (Meles meles) control. Epidemiol. Infect., 114: 179-93, 1995.

64- CLIFTON-HADLEY, R.S. Badgers, bovine tuberculosis and the age of reason. [Editorial] Br. Vet. J., 152: 243-5, 1996.

65- COLEMAN, J.D. Distribuition, prevalence and epidemiology of bovine tuberculosis in brushtail possuns, Trichosurus vulpecula, in the Hohonu Range, New Zealand. Aust. Wildl. Res., 15: 651-63, 1988.

66- COLLINS, C.H.; YATES, M.D.; GRANGE, J.M. A study of bovine strains of Mycobacterium tuberculosis isolated from humans in south-east England, 1977-1979. Tubercle, 62: 113-6, 1981. 
67- COLLINS, C.H.; YATES, M.D.; GRANGE, J.M. Human-to-human spread of infection by M.bovis. [Letter] Tubercle, 63: 143-4, 1982.

68- COLLINS, C.H. \& GRANGE, J.M. The bovine tubercle bacillus: a review. J. Appl. Bacteriol., 55: 13-29, 1983.

69- COLLINS, D.M.; LISLE, G.W. de; GABRIC, D.M. Geographic distribuiton of restriction types of Mycobacterium bovis isolates from brush-tailed possums (Trichosurus vulpecula) in New Zealand. J. Hyg. Lond., 96: 431$8,1986$.

70- COLLINS, D.M.; GABRIC, D.M.; LISLE, G.W. de. Typing of Mycobacterium bovis isolates from cattle and other animals in the same locality. N. Z. Vet. J., 36: 45-6, 1988.

71- COLLINS, F.M. The immune response to mycobacterial infection: development of new vaccines. Vet. Microbiol., 40: 95-110, 1994.

72- COLlinS, D.M.; LISLE, G.W. de; COLLINS, J.D. et al. DNA restriction fragment typing of Mycobacterium bovis isolates from cattle and badgers in Ireland. Vet. Rec., 134: 681-2, 1994.

73- COLLINS, D.M.; RADFORD, A.J.; LISLE, G.W. de et al. Diagnosis and epidemiology of bovine tuberculosis using molecular biological approaches. Vet. Microbiol., 40: 83-94, 1994.

74- COMISION NACIONAL DE ZOONOSIS. La tuberculosis bovina en la Republica Argentina. Buenos Aires, 1982. p. 39-62.

75- COOK, A.J.C.; TUCHILI, L.M.; BUVE, A. et al. Human and bovine tuberculosis in the Monze district of Zambia: a cross-sectional study. $B r$. Vet. J., 152: 37-46, 1996.

76- CORMICAN, M.G. \& FLYNN, J. Tuberculosis in the west of Ireland 19861990. Ir. J. Med. Sci., 161(3): 70-2, 1992. 
77- CORNER, L.A. \& NICOLACOPOULOS, C. Comparison of media used for the primary isolation of Mycobacterium bovis by veterinary and medical diagnostic laboratories. Aust. Vet. J., 65(7): 202-5, 1988.

78- CORNER, L.A. Post mortem diagnosis of Mycobacterium bovis infection in cattle. Vet. Microbiol., 40: 53-63, 1994.

79- CORREA, C.N.M. \& CORREA, W.M. Mycobacterium. Classificação de amostras isoladas de bovinos e suínos. In: Congresso Brasileiro de Medicina Veterinária, 13º, Brasília, DF, 1972. Anais. Brasília, DF, Sociedade Brasileira de Medicina Veterinária, 1972. p.292.

80- CORREA, W.M. \& CORREA, C.N.M. Mycobacterium: classificação das principais espécies isoladas do homem e dos animais. Rev. Div. Nac. Tuberc., 17(67): 332-40, 1973.

81- CORRÊA, C.N.M. \& CORREAA, W.M. Tuberculose humana por bacilo bovino em São Paulo, Brasil. Arq. Inst. Biol., São Paulo, 41: 131-4, 1974.

82- CORREA, C.N.M.; CORREA, W.M.; SPAGO, N. et al. Tuberculose nervosa em vaca leiteira. Arq. Esc. Vet. UFMG, 32: 265-9, 1980.

83- COSTALLAT, L.F.; CASTRO, A.F.P.; SIMON, F. et al. Mycobacteriosis in monkeys: a report of two cases. Vet. Med. Small Anim. Clin., 73: 651-5, 1978.

84- COTTER, T.P.; O'SHAUGHNESSY, E.; SHEEHAN, S. et al. Human Mycobacterium bovis infection in the south-west of Ireland 1983-1992: a comparison with M.tuberculosis. Ir. Med. J., 89: 62-3, 1996.

85- COTTER, T.P.; SHEEHAN, S.; CRYAN, B. et al. Tuberculosis due to Mycobacterium bovis in humans in the south-west region of Ireland: is there a relationship with infection prevalence in cattle? Tuber. Lung Dis., 77(6): 545-8, 1996. 
86- COUSINS, D.V.; WILLIAMS, S.N.; ROSS, B.C. et al. Use of a repetitive element isolated from Mycobacterium tuberculosis in hybridization studies with Mycobacterium bovis: a new tool for epidemiological studies of bovine tuberculosis. Vet. Microbiol., 37: 1-17, 1993.

87- COUSINS, D.V.; FRANCIS, B.R.; CASEY, R. et al. Mycobacterium bovis infection in a goat. Aust. Vet. J., 70: 262-3, 1993.

88- CRUZ, J.B.; BERSFORD Jr., H.S.; GUEDES, F.V. et al. Tuberculose pulmonar em cão. Diagnóstico histopatológico. In: Congresso Brasileiro de Zoonoses, Rio de Janeiro, 1987. Anais . p.46.

89- DABORN, C.J. \& GRANGE, J.M. HIV/AIDS and its implications for the control of animal tuberculosis. Br. Vet. J., 149: 405-17, 1993.

90- DABORN, C.J.; GRANGE, J.M.; KAZWALA, R.R. The bovine tuberculosis cycle: an African perspective. J. Appl. Bacteriol., 81 (Suppl.): 27S-32S, 1996.

91- DALOVISIO, J.R.; STETTER, M.; MIKOTA-WELLS, S. Rhinoceros' rhinorrhea: cause of an outbreak of infection due to airborne Mycobacterium bovis in zookeepers. Clin. Infect. Dis., 15: 598-600, 1992.

92- DANKNER, W.M.; WAECKER, N.J.; ESSEY, M.A. et al. Mycobacterium bovis infections in San Diego: a clinicoepidemiologic study of 73 patients and a historical review of a forgotten pathogen. Medicine, Baltimore, $\mathbf{7 2}$ : 11-37, 1993.

93- DAVID, H.; BRUM, L.; PRIETO, E. Manual de micobacteriologia em Saúde Pública. princípios e métodos. Lisboa. Instituto de Higiene e Medicina Tropical, 1994.

94- DESHPANDE, B.R.; SARDESHPANDE, P.D.; SANE, C.R. et al. Tuberculous endometritis in a buffalo cow. Indian Vet. J., 43: 288-90, 1966. 
95- DI LONARDO, M.; ISOLA, N.C.; AMBROGGI, M. et al. Mycobacteria in HIV-infected patients in Buenos Aires. Tuber. Lung Dis., 76(3): 185-9, 1995.

96- DINIZ, L.S.M. Tuberculose em primata. CCV: Clín. Cir. Veterinária., 1:(1): 22, 1982.

97- DINIZ, L.S.M. \& MARTIN, B.W. Clinical aspects of tuberculosis in a chimpanzee. Vet. Med. Small Anim. Clin., 78: 1289-91, 1983. 275-DINIZ, L.S.M. Tuberculose em primata. CCV: Clín. Cir. Veterinária., 1:(1): 22, 1982.

98- DINIZ, L.S.M.; COSTA, E.O.; FAVA NETTO, C. et al. Tuberculose em Cebus sp (macaco-prego) mantidos em cativeiro. [Resumo]. Ciênc. Cult., 40(Supl.,parte.I): 306, 1993. [Apresentado à 45ª Reunião Anual da SBPC, Pernambuco, 1993].

99- DINIZ, L.S.M.; COSTA, E.O.; FAVA NETTO, C. Importância e avaliação do teste de hipersensibilidade do tipo tardio - Tuberculina - em mamíferos silvestres mantidos em cativeiro São Paulo, Brasil. Hora Vet., 14(82): 52-4, 1994.

100-DOLAN, L.A. \& LYNCH, K. Badgers and bovine tuberculosis. Ir. Vet J., 45 : 133-5, 1992.

101-DOLIN, P.J.; RAVIGLIONE, M.C.; KOCHI, A. Global tuberculosis incidence and mortality during 1990-2000. Bull. Pan. Am. Health Organ., 72: 21320, 1994.

102-DREESEN, D.W. \& WOOD, A.R. A human case of Mycobacterium bovis infection in Georgia. Am. Rev. Respir. Dis., 101: 289-92, 1970.

103-DUFFIELD, B.J. \& YOUNG, D.A. Survival of Mycobacterium bovis in defined environmental conditions. Vet. Microbiol., 10:193-7, 1985. 
104-DUMARS, A.; ROBLOT, P.; BURUCOA, C. et al. Tuberculose généralisée à Mycobacterium bovis chez une malade âgée en dehors de l'infection à VIH. Rev. Méd. Interne, 16(2): 143-5, 1995.

105-EKDAHL, M.O; SMITH, B.L.; MONEY, D.F.L. Tuberculosis in some wild and feral animals in New Zealand. N. Z. Vet. J., 18: 44-5, 1970.

106-ESSEY, M.A. \& KOLLER, M.A. Status of bovine tuberculosis in North America. Vet. Microbiol., 40: 15-22, 1994.

107-FANNING, A. \& EDWARDS, S. Mycobacterium bovis infection in humans exposed to elk in Alberta. Can. Dis. Wkly. Rep., 17(44): 239-43, 1991.

108-FANNING, A. \& EDWARDS, S. Mycobacterium bovis infection in human beings in contact with elk (Cervus elaphus) in Alberta, Canada. Lancet, 338: 1253-5, 1991.

109-FARMERS call for overhaul of badger control policy. Vet. Rec., 4: 475-6, 1995.

110-FELDMAN, J. Tuberculose humana de origem bovina: contribuição ao seu estudo no Estado de Minas Gerais. Minas Gerais, 1955. [Tese de concurso para catedrático de Tisiologia - Faculdade de Medicina da Universidade de Minas Gerais].

111-FESTENSTEIN, F. \& GRANGE, J.M. Tuberculosis and the acquired immune deficiency syndrome: a review. J. Appl. Bacteriol., 71: 19-30, 1991.

112-FIFIS, T.; CORNER, L.A.; ROTHEL, J.S. et al. Cellular and humoral immune responses of cattle to purified Mycobacterium bovis antigens. Scand. J. Immunol., 39: 267-74, 1994.

113-FIGUEIREDO, R.C.P.S. Estudo da utilização do método bacteriológico no diagnóstico da tuberculose pulmonar no município de Taubaté- São Paulo, 1993-94. São Paulo, 1996. [Dissertação de Mestrado - Faculdade de Saúde Pública da Universidade de São Paulo] 
114-FISON, T. Bovine TB in south Sudan. [Letter] Vet. Rec., 139: 244, 1996.

115-FLAMAND, J.R.B.; GRETH, A.; HAAGSMA, J. et al. An outbreak of tuberculosis in a captive herd of arabian oryx (Oryx leucoryx): diagnosis and monitoring. Vet. Rec., 134: 115-8, 1994.

116-FONSECA, F.C. Como combater a brucelose e tuberculose. Agric. Hoje, 8(84): 20-4, 1982.

117-FONTAINE, G.A. Tuberculose des carnivores: données actuelles et perspectives. Point. Vét., 26(159): 45-8, 1994.

118-FRANCIS, J. Very small public health risk from flesh of tuberculous cattle Aust. Vet. J., 49: 496-7, 1973.

119-FREITAS, J.A. Tuberculose em um búfalo (Bubalus bubalis var. bubalisLinneus,1758) In: Congresso Brasileiro de Medicina Veterinária, $18^{\circ}$, Balneário Camboriú, SC, 1982. Anais. Balneário Camboriú, SC, Sociedade Brasileira de Medicina Veterinária, 1982. p.365.

120-GALlAGHER, J.; MUIRHEAD, R.H.; BURN, K.J. Tuberculosis in wild badgers (Meles meles) in Gloucestershire: pathology. Vet. Rec., 98: 9-14, 1976.

121-GARCÍA, M.L.G.; GÓMEZ, J.L.V.; SANCHO, M.C.G. et al. Epidemiology of AIDS and tuberculosis. Bull. Pan. Am. Health Organ., 29: 37-51, 1995.

122-GAY, W.I. Tuberculosis in the eye of a monkey. J. Am.Vet. Med. Assoc., 127: 225-6, march, 1955.

123-GOODGER, J.; NOLAN, A.; RUSSEL, W.P. et al. Serodiagnosis of Mycobacterium bovis infection in badgers: development of an indirectMycobacterium bovis infection. Vet. Microbiol., 40: 137-51, 1994. 
124-GOODGER, J.; RUSSEL, W.P.; NOLAN, A. et al. Production and characterization of a monoclonal badger anti-immunoglobulin $\mathrm{G}$ and its use in defining the specificity of Mycobacterium bovis infection in badgers by western blot. Vet. Immunol. Immunopathol., 40: 243-52, 1994.

125-GRANGE, J.M. \& COLLINS, C.H. Bovine tubercle bacilli and disease in animals and man: special article. Epidemiol. Infect., 92: 221-34, 1987.

126-GRANGE, J.M.; COLLINS, J.D.; O’REILLY, L.M. et al. Identification and characteristics of Mycobacterium bovis isolated from cattle, badgers and deer in the Republic of Ireland. Ir. Vet. J., 43: 33-5, 1990.

127-GRANGE, J.M. \& YATES, M.D. Zoonotic aspects of Mycobacterium bovis infection. Vet. Microbiol., 40: 137-51, 1994.

128-GRANGE, J.M. \& YATES, M.D. Guidelines for speciation within the Mycobacterium tuberculosis complex. Geneva, World Health Organization, (WHO/Zoon./94.174), 1994.

129-GRANGE, J.M.; DABORN, C.; COSIVI, O. HIV-related tuberculosis due to Mycobacterium bovis. [Editorial] Eur. Respir. J., 7: 1564-6, 1994.

130-GRANGE, J.M. Human and bovine tuberculosis: new threats from an old disease. [Editorial] Br. Vet. J., 152: 3-4, 1996.

131-GREENE, G.E. Infectious diseases of the dog and cat. Philadelphia, W.B. Saunders, 1990. p.558-66: Mycobacterial infections.

132-GRETH, A.; FLAMAND, J.R.B.; DELHOMME, A. An outbreak of tuberculosis in a captive herd of arabian oryx (Oryx leucoryx): management. Vet. Rec., 134: 165-7, 1994.

133-GRIFFIN, J.F.T.; HESKETH, J.B.; MACKINTOSH, C.G. et al. BCG vaccination in deer: distinctions between delayed type hypersensitivity and laboratory parameters of immunity. Immunol. Cell Biol., 71: 559-70, 1993. 
134-GRIFFIN, J.F.T. \& BUCHAN, G.S. Aetiology, pathogenesis and diagnosis of Mycobacterium bovis in deer. Vet. Microbiol., 40: 193-205, 1994.

135-GRIFFITH, A.S. Tuberculosis of the domesticated species of animals. J. Comp. Pathol., 45: 53-75, 1928.

136-GRIFFITH, A.S. Tuberculosis of the domesticated species of animals. J. Comp. Pathol., 45: 109-22, 1928.

137-GRIFFITH, A.S.; TYTLER, W.H.; CUMMINS, S.L. et al. Bacillus tuberculosis. In: Fildes, P. \& Ledingham, J.C.G, (ed.) A system of bacteriology in relation to medicine. London, Medical Research Council / His Magesty's Stationery Office, 1930. v.5, chap.4: 151-325.

138-GROSSET, J. \& MOUTON, Y. Is PCR a useful tool for the diagnosis of tuberculosis in 1995?. Tuber. Lung Dis., 76: 183-4, 1995.

139-GUNN-MOORE, D.A. \& JENKINS, P.A. Tuberculosis in cats [Letter; comment]. Vet. Rec., 134: 395, 1994.

140-GUTIÉRREZ, M.; SAMPER, S.; GAVIGAN, J.A. et al. Differentiation by molecular typing of Mycobacterium bovis strains causing tuberculosis in cattle and goats. J. Clin. Microbiol., 33: 2953-6, 1995.

141-HABIB, N.I. \& WARRING, F.C. A fatal case of infection due to Mycobacterium bovis. Am. Rev. Respir. Dis., 93: 804-10, 1966.

142-HADAD, D. J. Micobactérias isoladas de pacientes portadores do vírus da imunodeficiência humana na Grande São Paulo: aspectos microbiológicos, epidemiológicos, clínicos e laboratoriais. São Paulo, 1994. [Dissertação de Mestrado - Escola Paulista de Medicina].

143-HANCOX, M. Cattle TB: 'VL, open' cases...or 'NVL, non-infectious' cases?. [Letter] Respir. Med., 89: 712, 1995. 
144-HANCOX, M. Badgers and bovine TB: a reappraisal of 'VL/NVL' infectious cattle. Lett. Appl. Microbiol., 22: 95-6, 1996.

145-HANCOX, M. New human light on bovine TB in cattle and wildlife? [Letter] Respir. Med., 90:184, 1996.

146-HANCOX, M. Bovine TB in badgers: a reappraisal of aetiology and pathogenesis. [Letter] Respir. Med., 90: 371-3, 1996.

147-HARD decisions on TB. Vet. Rec., 140: 437, 1997.

148-HARDIE, R.M. \& WATSON, J.M. Mycobacterium bovis in England and Wales: past, present and future. Epidemiol. Infect., 109: 23-33, 1992.

149-HUGHES, M.S.; NEILL, S.D.; ROGERS, M.S. Vaccination of badger (Meles meles) against Mycobacterium bovis. Vet. Microbiol., 51:363-79, 1996.

150-INDRIUNAS, L. Prefeituras fiscalizam leite no Pará. Folha de São Paulo, São Paulo, 30 ago. 1998. Cad.3, p.7.

151-ISAAC, J.; WHITEHEAD, J.; ADAMS, J.W. et al. An outbreak of Mycobacterium bovis infection in cats in an animal house. Aust. Vet. J., 60(8): 243-5, 1983.

152-ITOH, R.; KAGABU, Y.; ITOH, F. Mycobacterium bovis infection in a herd of japanese shika deer (Cervus nippon). J. Vet. Med. Sci., 54: 803-4, 1992.

153-KANTOR, I.N. \& LESSLIE, I.W. Aislamiento de mutantes resistentes a drogas antituberculosas en cepas salvajes de M.bovis. Medicina, Buenos Aires, 34: 244-8, 1974.

154-KANTOR, I.N. La tuberculose bovina en el hombre. Rev. Argent. Tuberc. Enferm. Pulm. Salud Publica, 43: 11-6, 1982.

155-KANTOR, I.N.; LOPEZ, B.; TORRES, P. et al. Preliminary evaluation of a simple method for detection of bovine tuberculosis: the glutaraldehyde test. J. Vet. Med. B, 40: 27-30, 1993. 
156-KANTOR, I.N. \& RITACCO, V. Bovine tuberculosis in Latin America and the Caribbean: current status, control and eradication programs. Vet. Microbiol., 40: 5-14, 1994.

157-KAVINSKI, L.C. \& KLEINER NETO, j. Tuberculose em cães e gatos. Inf. CRMV-3, Curitiba., 1(4):iv, 1984.

158-KAY, H.D. Metodos de pasteurizacion: descripcion general e inspecion de los resultados. In: Organizacion Mundial de La Salud Higiene de la leche. Ginebra, 1966. p. 277-89.

159-KITCHING, R.P. Tuberculosis and AIDS: a deadly combination. [Editorial] Br. Vet. J., 149: 403-4, 1993.

160-KLEEBERG, H.H. Tuberculose humaine d'origine bovine et santé publique. Rev. Sci. Tech. Off. Int. Epiz., 3: 33-54, 1984.

161-KOCHI, A. The global tuberculosis situation and the new control strategy of the World Health Organization. Tubercle, 72: 1-6, 1991.

162-KÖRMENDY, B. Achievements and dificulties in maintaining the tuberculosisfree status of hungarian cattle herds. Acta Vet. Hung., 43: 377-84, 1995.

163-KOVALYOV, G.K. On human tuberculosis due to M.bovis: a review. J. Hyg. Epidemiol. Microbiol. Immunol., 33: 199-206, 1989.

164-KRITSKI, A.; DALCOLMO, M.; BIANCO, R. del et al. Associação tuberculose e infecção pelo HIV no Brasil. Bol. Oficina Sanit. Panam., 118: 542-54, 1995.

165-LANGENEGGER, C.H.; MENKE, L.J.; LANGENEGGER, J. Micobactérias isoladas de lesões tuberculóides de linfonodos cervicais de suínos do Paraná, Brasil. In: Congresso Brasileiro de Medicina Veterinária, 13º, Brasília, DF, 1972. Anais. Brasília, DF, Sociedade Brasileira de Medicina Veterinária, 1972. p.292. 
166-LANGENEGGER, C.H.; LEITE, R.C.; LANGENEGGER, J. et al. Linfadenites tuberculóides em suínos de abate da região de Brasília. In: Congresso Brasileiro de Medicina Veterinária, 14º São Paulo, 1974. Anais. São Paulo, Sociedade Brasileira de Medicina Veterinária, 1974. p.88-9.

167-LANGENEGGER, C.H. \& LANGENEGGER, J. Resistência do gambá, Didelphis albiventris, à tuberculose. Pesq. Vet. Bras., 5: 103-7, 1985.

168-LANGENEGGER, J. Diagnóstico alérgico da tuberculose bovina. Pesq. Vet. Bras., 7(2):vii-viii, 1988.

169-LANGENEGGER, J.; LEITE, G.O.; OLIVEIRA Jr., J. Tratamento intermitente da tuberculose bovina com isoniazida. Pesq. Vet. Bras., 11(3/4): 55-9, 1991.

170-LATINI, M.D.S. de; LATINI, O.A.; LOPEZ, M.L. et al. Tuberculosis bovina en seres humanos $2^{a}$ parte: período 1977-1989. Rev. Argent.Torax, 51: 13-6, 1990.

171-LEÃO, S. C. Tuberculosis: new strategies for the development of diagnostic tests and vaccines. Braz. J. Med. Biol. Res., 26: 827-33, 1993.

172-LEITE, R.C.; MOTA, P.M.P.C.; MONTEIRO, J.X. et al. Incidência da tuberculose bovina em rebanhos produtores de leite tipo "B". In: Encontro de Pesquisa, $7^{\circ}$, Belo Horizonte, MG, 1978. Resumos dos trabalhos. Belo Horizonte, MG, Escola de Veterinária da UFMG, 1978.

173-LEPPER, A.W.D. \& CORNER, L.A. Naturally occurring mycobacterioses of animals. In: Ratledge, C. \& Stanford, J. The biology of the Mycobacteria. London, Academic Press., 1983. v.2, p. 417-521.

174-LESSLIE, I.W. Cross infections with mycobacteria between animals and man. Bull. Union Int. Tuberc., 41: 285-8, 1968. 
175-LESSLIE, I.W.; MAGNUS, K.; STEWART, C.J. The prevalence of bovine type tuberculous infection in man in the English rural population. Tubercle., 53: 198-204, 1972.

176-LIÉBANA, E.; ARANAZ, A.; MATEOS, A. et al. Simple and rapid detection of Mycobacterium tuberculosis complex organisms in bovine tissue samples by PCR. J. Clin. Microbiol., 33: 33-6, 1995.

177-LISLE, G.W. de \& HAVILL, P.F. Mycobacteria isolated from deer in New Zealand from 1970-1983. N. Z. Vet. J., 33: 138-40, 1985.

178-LISLE, G.W. de; COLLINS, D.M.; LOVEDAY, A.S. et al. A report of tuberculosis in cats in New Zealand, and the examination of strains of Mycobacterium bovis by DNA restriction endonuclease analysis. N. Z. Vet. J., 38: 10-3, 1990.

179-LISS, G.M.; WONG, L.; KITTLE, D.C. et al. Occupational exposure to Mycobacterium bovis infection in deer and elk in Ontario. Can. J. Public Health, 85: 326-9, 1994.

180-LITTLE, T.W.A.; SWAN, C.; THOMPSON, H.V. et al. Bovine tuberculosis in domestic and wild mammals in an area of Dorset. II. The badger population, its ecology and tuberculosis status. J. Hyg. Lond., 89: 211-24, 1982.

181-LITTLE, T.W.A.; SWAN, C.; THOMPSON, H.V. et al. Bovine tuberculosis in domestic and wild mammals in an area of Dorset. III. The prevalence of tuberculosis in mammals other than badgers and cattle. J. Hyg. Lond., 89: 225-34, 1982.

182-MADDOCK, E.C.G. Studies on the survival time of the bovine tubercle bacillus in soil, soil and dung, in dung and on grass, with experiments on the preliminary treatment of infected organic matter and the cultivation of the organism. J. Hyg. Lond., 33: 103-17, 1933. 
183-MAGNUS, K. Morbidity of respiratory tuberculosis among persons infected from bovine and human sources. Bull. Union Int. Tuberc., 35: 349-54, 1964.

184-MAGNUS, K. Epidemiological basis of tuberculosis eradication. 3. Risk of pulmonary tuberculosis after human and bovine infection. Bull. World Health Organ., 35: 483-508, 1966.

185-MASCHIO, J. Produto sem pasteurização vai para a merenda escolar. Folha de São Paulo, São Paulo, 30 ago. 1998. Cad.3, p.6.

186-McINERNEY, J.; SMALL, K.J.; CALEY, P. Prevalence of Mycobacterium bovis infection in feral pigs in the Northern Territory. Aust. Vet. J., 72: 448-51, 1995.

187-MIGLIANO, M. F. Tuberculose em cães. In: Congresso Brasileiro de Medicina Veterinária, $12^{\circ}$, Porto Alegre, RS, 1970. Anais. p.87-128.

188-MINISTÉRIO DA AGRICULTURA E DO ABASTECIMENTO. Secretaria de Defesa Agropecuária. Departamento de Defesa Animal. Bol. Def. Sanit. Anim., 22(1-4), 1989. [Edição publicada em 1992].

189-MINISTÉRIO DA AGRICULTURA E DO ABASTECIMENTO. Secretaria de Defesa Agropecuária. Departamento de Defesa Animal. Bol. Def. Sanit. Anim., 25(1-4), 1992. [Edição publicada em 1996]

190-MINISTÉRIO DA AGRICULTURA E DO ABASTECIMENTO. Secretaria de Defesa Agropecuária. Departamento de Defesa Animal. Bol. Def. Sanit. Anim., 26(1-4), 1993. [Edição publicada em 1997].

191-MINISTÉRIO DA SAÚDE. Secretaria Nacional de Programas Especiais de Saúde. Divisão de Pneumologia Sanitária. Campanha Nacional contra a Tuberculose. Controle da tuberculose: uma proposta de integração ensinoserviço. $4^{\mathrm{a}}$ ed. Brasília, 1994. 
192-MINISTÉRIO DA SAÚDE. Fundação Nacional de Saúde. Centro de Referência Professor Hélio Fraga. Manual de bacteriologia da tuberculose. $2^{\mathrm{a}}$ ed. Rio de Janeiro, 1994.

193-MINISTÉRIO DA SAÚDE. Fundação Nacional de Saúde. Centro Nacional de Epidemiologia. Coordenação Nacional de Pneumologia Sanitária. Manual de normas para o controle da tuberculose. $4^{\mathrm{a}}$ ed. Brasília, 1995. (Série A: Normas e Manuais Técnicos, 13).

194-MIRSKY, M.L.; MORTON, D.; PIEHL, J.W. et al. Mycobacterium bovis infection in a captive herd of sika deer. J. Am. Vet. Med. Assoc., 200: 1540$2,1992$.

195-MITTAINE, J. Leches distintas de la leche de vaca. In: Organizacion Mundial de La Salud. Higiene de la leche. Ginebra, 1966. p.733-46.

196-MODA, G.; DABORN, C.J.; GRANGE, J.M. et al. The zoonotic importance of Mycobacterium bovis. Tuber. Lung Dis., 77: 103-8, 1996.

197-MONAGHAN, M.L.; DOHERTY, M.L.; COLLINS, J.D. et al. The tuberculin test. Vet. Microbiol., 40: 111-24, 1994.

198-MONTANER, G.L.J.; ABBATE, E.H.; DI LONARDO, M. et al. Human tuberculosis caused by Mycobacterium bovis: report of 66 cases. Tuber. Lung Dis., 76: 110, 1995.

199-MORRIS, R.S.; PFEIFFER, D.U.; JACKSON, R. The epidemiology of Mycobacterium bovis infections. Vet. Microbiol., 40: 153-77, 1994.

200-MOTA, P.M.P.C. Diagnósticos alérgicos da tuberculina bovina. Inf. LANARA, Brasília, 4(18): 55-62, 1982.

201-MOTA, P.M.P.C. \& NAKAJIMA, M. Tuberculose bovina. In: Charles, T.P. \& Furlong, J. Doenças dos bovinos de leite adultos. Coronel Pacheco, EMBRAPA - CNPGL, 1992. p. 97-122. 
202-MOTA, T.M.B.; ALBUQUERQUE, A.J.D.; SANTOS, A.F. Micobactérias isoladas de gânglios linfáticos de bovinos, tuberculina positivos. Rev. Cent. Ciênc. Rurais, 7: 9-14, 1977.

203-MUIRHEAD, R.H.; GALLAGHER, J.; BURN, K.J. Tuberculosis in wild badgers in Gloucestershire: epidemiology. Vet. Rec., 95: 552-5, 1974.

204-NAZÁRIO, W.; MARTINI, M.; CAMBRIA, A.M. Tuberculose: um poderoso inimigo que deve ser evitado. Balde Branco, 22(271): 24-6, 1987.

205-NEILL, S.D.; O'BRIEN, J.J.; HANNA, J. A mathematical model for Mycobacterium bovis excretion from tuberculous cattle. Vet. Microbiol., 28: 103-9, 1991.

206-NEILL, S.D.; HANNA, J.; MACKIE, D.P. et al. Isolation of Mycobacterium bovis from the respiratory tracts of skin test-negative cattle. Vet. Rec., 131: 45-7, 1992.

207-NEILL, S.D.; CASSIDY, J.; HANNA, J. et al. Detection of Mycobacterium bovis infection in skin test-negative catlle with an assay for bovine interferon-gamma. Vet. Rec., 135: 134-5, 1994.

208-NEILL, S.D.; POLLOCK, J.M.; BRYSON, D.B. et al. Pathogenesis of Mycobacterium bovis infection in cattle. Vet. Microbiol. 40: 41-52, 1994.

209-NEWELL, D.G. \& HEWINSON, R.G. Control of bovine tuberculosis by vaccination. Vet. Rec., 136: 459-63, 1995.

210-NOLAN, A. \& WILESMITH, J.W. Tuberculosis in badgers (Meles meles). Vet. Microbiol., 40: 179-91, 1994.

211-NOONAN, N.L.; SHEANE, W.D.; HARPER, L.R. et al. Wild-life as a possible reservoir of bovine tuberculosis. Ir. Vet. J., 29: 1, 1975.

212-NORTON, R.E.; LUMB, R.; SHAW, D.R. Mycobacterium bovis meningitis. [Letter] Med. J. Aust., 162: 276-7, 1995. 
213-OLIVEIRA, P.R.; COELHO, H.E.; REIS, D.O. et al. Prevalência da tuberculose em carcaças e vísceras de bovinos abatidos em Uberlândia. Arq. Bras. Med. Vet. Zoot., 38: 965-71, 1986.

214-OLIVEIRA, S.J. de; PIANTA, C.; RAMOS, E.T. et al. Salud publica veterinaria: un estudio sobre tuberculosis en ganado lechero. Bol. Oficina Sanit. Panam., 94: 142-9, 1983.

215-OLIVEIRA, S.J. Tuberculose em suínos. Hora Vet., 9(49): 31-6, 1989.

216-O'REILLY, L.M. \& DABORN, C.J. The epidemiology of Mycobacterium bovis infections in animals and man: a review. Tuber. Lung Dis., 76 (Supplement 1): 1-46, 1995.

217-ORGANIZACIÓN PANAMERICANA DE LA SALUD. Reunión internacional para la erradicación de la tuberculosis bovina en las Américas. Bol. Oficina Sanit. Panam., 113: 357-60, 1992.

218-ORGANIZACIÓN PANAMERICANA DE LA SALUD. Situacion de la tuberculosis bovina en las Americas Washington, D.C., 1995. (RIMSA 9/INF/26. Esp.)

219-ORTIZ, R.E. Cuba: eradication of bovine tuberculosis. World Anim. Rev., 59: 34-7, 1986.

220-PACKER, R.A. Veterinarians challenge Dr. Robert Koch regarding bovine tuberculosis and public health. J. Am. Vet. Med. Assoc., 196: 574-5, 1990.

221-PANDE, T.K.; HIRAN, S.; RAO, V.V.B. et al. Primary lingual tuberculosis caused by M.bovis infection. Oral Surg. Oral Med. Oral Pathol. Oral Radiol. Endod., 80: 172-4, 1995.

222-PASSOS, E.C.; ITO, F.H.; VASCONCELLOS, S.A. et al. Investigação epidemiológica sobre as zoonoses de maior constatação em matadouros.I. suínos. Rev. Fac. Med. Vet. Zootec. Univ. S. Paulo, 26: 39-51, 1989. 
223-PAULA, A. Tuberculose: ontem, hoje e amanhã. JBM., 55: 74-100, 1988.

224-PINHEIRO, S.R. Influência da matéria orgânica na atividade micobactericida de cinco desinfetantes químicos de uso pecuário. São Paulo, 1990. [Dissertação de Mestrado - Faculdade de Medicina Veterinária e Zootecnia da Universidade de São Paulo].

225-PINHEIRO, S.R. Influência da origem da estirpe AN5 de Mycobacterium bovis, da temperatura de contato e da matéria orgânica sobre a atividade micobactericida do hipoclorito de sódio ou de aldeídos. São Paulo, 1994. [Tese de Doutorado - Faculdade de Medicina Veterinária e Zootecnia da Universidade de São Paulo].

226-PORTUGAL, M.A.S.C.; GIORGI, W.; SIQUEIRA, P.A. Ocorrência de tuberculose em rebanho bubalino (Bubalus bubalis var. bubalisLinneus, 1758) no Estado de São Paulo. Arq. Inst. Biol., São Paulo., 38:231-8, 1971.

227-PORTUGAL, M. A. S. C.; CALILI, E.M.B.; FARINHA, F.B.N. et al. Surto de tuberculose em criação de chinchilas (Chinchilla lanígera). Arq. Inst. Biol., São Paulo., 57: 57-61, 1990.

228-PRITCHARD, D.G. A century of bovine tuberculosis 1888-1988: conquest and controversy. J. Comp. Pathol., 99: 357-99, 1988.

229-PUSTIGLIONE NETO, L. Saúde animal. In: Curso Internacional sobre Tecnologia da Carne, $1^{\circ}$, Campinas, São Paulo, 1978. Campinas, Instituto Tecnológico de Alimentos, 1978. p.2.1-2.6.

230-RAVIGLIONE, M.C.; SNIDER, D.E.; KOCHI, A. Global epidemiology of tuberculosis: morbidity and mortality of a worldwide epidemic. JAMA, 273: 220-6, 1995.

231-REILLY, L.V. Human tuberculosis of bovine origin in northern Ireland. J. Hyg. Lond., 48: 464-71, 1950. 
232-RICCETTI, R.V.; VASCONCELLOS, S.A.; ITO, F.H. et al. Investigação epidemiológica sobre as zoonoses de maior constatação em matadouros. II. Bovinos. Rev. Fac. Med. Vet. Zootec. Univ. S. Paulo, 26: 61-8, 1989.

233-RITACCO, V.; KANTOR, I.N.; BARRERA, L. et al. Assessment of the sensitivity and specificity of Enzime-Linked Immunosorbent Assay (ELISA) for the detection of Mycobacterial antibodies in bovine tuberculosis. J. Vet. Med. B., 34: 119-25, 1987.

234-RITACCO, V.; LÓPEZ, B.; BARRERA, L. et al. Further evaluation of an indirect enzime-linked immunosorbent assay for the diagnosis of bovine tuberculosis. J. Vet. Med. B., 37: 19-27, 1990.

235-RITACCO, V. \& KANTOR, I.N. Zoonotic tuberculosis in Latin America. [Letter;comment] J. Clin. Microbiol., 30: 3299-300, 1992.

236-ROSEMBERG, J.; TARANTINO, A.B.; PAUlA, A. et al. Tuberculose. In: Tarantino, A.B. Doenças Pulmonares. $3^{\mathrm{a}}$ ed. Rio de Janeiro, Guanabara Koogan, 1990. p.233-97.

237-ROSEMBERGER, G. Enfermedades de los bovinos. Buenos Aires, Editorial Hemisferio Sur, 1983. v.2. p.139-51.

238-ROXO, E.; ALBERTI, H.; ALBERTI, A.L.L. Ocorrência de tuberculose avançada em bezerro. Arq. Inst. Biol., São Paulo., 57(Supl.): 74, 1990.

239-ROXO, E.; DIAS, B.C.; PORTUGAL, M.A.S.C. Tuberculose genital em bovinos. In: Congresso Brasileiro de Microbiologia, 17º, Santos, SP, 1993. Resumos dos trabalhos. São Paulo, Sociedade Brasileira de Microbiologia, 1993. p.170.

240-ROXO, E. Avaliação da resposta imunoalérgica cutânea à tuberculina em bubalinos (Bubalus bubalis). São Paulo, 1996. [Tese de Doutorado Faculdade de Medicina Veterinária e Zootecnia da Universidade de São Paulo]. 
241-ROXO, E. Tuberculose e brucelose em búfalos. In: Oliveira, G.J.C.; Almeida, A.M.L.; Souza Filho, U.A., ed. O búfalo no Brasil Cruz das Almas, BA, Escola de Agronomia da UFBA, 1997. p.185-96. [Anais do Simpósio Brasileiro de Bubalinocultura, Cruz das Almas, BA, 1996].

242-ROXO, E.; VASCONCELLOS, S.A.; PINHEIRO, S.R. Estudo comparativo da estrutura da pele de bubalinos (Bubalus bubalis) e bovinos (Bos taurus). Arq. Inst. Biol., São Paulo, 64:117-20, 1997.

243-ROXO, E.; VASCONCELLOS, S.A.; PINHEIRO, S.R. et al. Evaluation of tuberculin skin reaction in buffaloes (Bubalus bubalis). Arq. Inst. Biol., São Paulo, 65: 81-92, 1998.

244-SALIBA, A.M.; MORENO, G.; MIGLIANO, M.F. Tuberculose em gato produzida pelo Mycobacterium tuberculosis. Arq. Inst. Biol., São Paulo, 37:77-9, 1970.

245-SAMPAIO, S.B. A tuberculose ataca o homem e os animais. Produtor Leite, 8(40): 60, 1977.

246-SANSON, R.L.; PFEIFFER, D.U.; MORRIS, R.S. Geographic information systems: their application in animal disease control. Rev. Sci. Tech. Off. Int. Epiz., 10: 179-95, 1991.

247-SANTOS, V.T.; SANTOS, A.F.; SANTOS, T. et al. Verificação do comportamento de duas amostras de tuberculina (PPD) empregadas intradermo-caudamente, frente a um surto de tuberculose bovina, em gado de corte, no Rio Grande do Sul. Rev. Cent. Ciênc. Rurais, 8: 199-204, 1978 .

248-SAURET, J.; JOLIS, R.; AUSINA, V. et al. Human tuberculosis due to Mycobacterium bovis: report of 10 cases. Tuber. Lung Dis., 73: 388-91, 1992. 
249-SCHULTSZ, C.; KUIJPER, E.J.; SOOLINGEN, D. van et al. Disseminated infection due to multidrug-resistant Mycobacterium bovis in a patient who was seropositive for human immunodeficiency virus. Clin. Infect. Dis., 23: 841-3, 1996.

250-SILVA, N.Q.; ARAÚJO, P.G.; PRATA, F.G. Um caso de tuberculose genital em touro. Rev. Bras. Reprod. Anim., 4(1/2): 23-5, 1980.

251-SJÖGREN, I. \& SUTHERLAND, I. Studies of tuberculosis in man in relation to infection in cattle. Tubercle, 56: 113-27, 1974.

252-SKUCE, R.A.; BRITTAIN, D.; HUGHES, M.S. et al. Genomic fingerprinting of Mycobacterium bovis from cattle by restriction fragment length polymorphism analysis. J. Clin. Microbiol., 32: 2387-92, 1994.

253-SMITH, E.; THYBO, S.; BENNEDSEN, J. Infection with Mycobacterium bovis in a patient with AIDS: a late complication of BCG vaccination. Scand. J. Infect. Dis., 24: 109-10, 1992.

254-SOOLINGEN, D. Van; HAAS, P.E.W. de; HAAGSMA, J. et al. Use of various genetic markers in differentiation of Mycobacterium bovis strains from animals and humans and for studying epidemiology of bovine tuberculosis. J. Clin. Microbiol., 32: 2425-33, 1994.

255-STEELE, J.H. Bacterial, Rickettsial and mycotic diseases. In: Handbook series in zoonosis. CRC Press, 1979. Section A. p. 3-13.

256-STETTER, M.D.; MIKOTA, S.K.; GUTTER, A.F. et al. Epizootic of Mycobacterium bovis in a zoologic park. J. Am. Vet. Med. Assoc., 207(12): 1618-21, 1995.

257-SUCCI, R.C.M. Tuberculose. Clin. Pediatr., 2(12): 30-8, 1976.

258-SZEWZYK, R.; SVENSON, S.B.; HOFFNER, S.E. et al. Molecular epidemiological studies of Mycobacterium bovis infections in humans and animals in Sweden. J. Clin. Microbiol., 33: 3183-5, 1995. 
259-TB and deer farming: return of the king's evil?. [Editorial] Lancet, 338 (8777): 1243-4, 1991.

260-THOEN, C.O.; RICHARDS, W.D.; JARNAGIN, J.L. Mycobacteria isolated from exotic animals. J. Am. Vet. Med. Assoc., 170(9): 987-90, 1977.

261-THOEN, C.O.; KARLSON, A.G.; HIMES, E.M. Mycobacterium tuberculosis complex. In: Kubica, G.P. \& Wayne, L.G. The Mycobacteria: a sourcebook. New York, Marcel Dekker, 1984. Part B. p. 1209-35.

262-THOEN, C.O. \& HIMES, E.M. Pathogenesis of Mycobacterium bovis infection. Prog. Vet. Microbiol. Immun., 2: 198-214, 1986.

263-THOMPSON, P.J.; COUSINS, D.V.; GOW, B.L. et al. Seals, seal trainers, and Mycobacterial infection. Am. Rev. Respir. Dis., 147: 164-7, 1993.

264-THOREL, M.F. Le rôle du laboratoire dans le contrôle de la tuberculose chez les animaux. Point Vét., 26(159): 35-40, 1994.

265-THOREL, M.F. \& MOUTOU, F. Tuberculose et animaux sauvages. Point Vét., 26(159): 27-34, 1994.

266-TÖRNING, K. Bovine tuberculosis: with a case report and some remarks. Dis. Chest, 47: 241-6, 1965.

267-TUBERCULOSE bovina. Rev. Criadores, 42(510): 94, 1972.

268-TUBERCULOSIS and badgers. [news] Vet. Rec., 129(21): 458-9, 1991.

269- TWEDDLE, N.E. \& LIVINGSTONE, P. Bovine tuberculosis control and eradication programs in Australia and New Zealand. Vet. Microbiol., 40: 23-39, 1994.

270-VAITSMAN, J. Importância dos animais na expansão e transmissão da tuberculose humana. Agric. Hoje, 1(6): 22-3, 1975. 
271-VALE, W.G.; MENDES, J.P.V.; BRAGA, M.S. Tuberculose genital em búfala - Bubalus bubalis Lin. In: Congresso Brasileiro de Medicina Veterinária, 16 , Salvador, BA, 1978. Anais. Salvador, BA, Sociedade Brasileira de Medicina Veterinária, 1978. p.151-2.

272-VASCONCELLOS, S.A. Epidemiologia da tuberculose: tema apresentado no Painel sobre Tuberculose. Comun. Cient. Fac. Med. Vet. Zootec. Univ. S. Paulo, 3(1/2): 81-9, 1979.

273-VERA, A.; COTRINA, N.; BOTELlO, A. et al. Experiencias sobre la eliminación de la tuberculosis bovina en un distrito ganadero y su efecto sobre la producción láctea. Rev. Cubana Cienc. Vet., 15: 17-24, 1984.

274-VETERINARY public health: zoonotic tuberculosis (Mycobacterium bovis). Wkly. Epidemiol. Rec., 69(19): 139-40, 1994.

275-VINCENT, V. Epidémiologie de la tuberculose chez l'homme. Point Vét., 26 (159): 41-4, 1994.

276-WALKER, E. Tuberculosis persists in US livestock. J. Am. Vet. Med. Assoc., 209: 1529-30, 1996.

277-WARDS, B.J.; COLLINS, D.M.; LISLE, G.W. de. Detection of Mycobacterium bovis in tissue by polymerase chain reaction. Vet. Microbiol., 43(2-3): 22740, 1995.

278-WHITE, P.C.L.; BROWN, J.A.; HARRIS, S. Badgers (Meles meles), cattle and bovine tuberculosis (Mycobacterium bovis): a hypothesis to explain the influence of habitat on the risk of disease transmission in southwest England. Proc. R. Soc. Lond. B, 253(1338): 277-84, 1993.

279-WHITE, P.C.L. \& HARRIS, S. Bovine tuberculosis in badger (Meles meles) populations in southwest England: an assessment of past, present and possible future control strategies using simulation modelling. Phil. Trans. R. Soc. Lond. B, 349(1330): 415-32, 1995. 
280-WHITING, T.L. \& TESSARO, S.V. An abattoir study of tuberculosis in a herd of farmed elk. Can. Vet. J., 35: 497-501, 1994.

281-WIESNER, E. Enfermedades del ganado bovino. Zaragoza, Acribia, 1973. p. 123-9.

282-WIESNER, E. Enfermedades del ganado bovino. Zaragoza, Acribia, 1973. p. $370-1$.

283-WIGLE, W.D.; ASHLEY, M.J.; KILLOUGH, E.M. et al. Bovine tuberculosis in humans in Ontario: the epidemiologic features of 31 active cases occurring between 1964 and 1970. Am. Rev. Respir. Dis., 106: 528-34, 1972.

284-WILD, R. Bovine tuberculosis eradication deadline extended. [News] Aust. Vet. J., 67: 69-70, 1990.

285-WILESMITH, J.W.; LITTLE, T.W.A.; THOMPSON, H.V. et al. Bovine tuberculosis in domestic and wild mammals in an area of Dorset. I. Tuberculosis in cattle. J. Hyg. Lond., 89: 195-210, 1982.

286-WILESMITH, J.W. Epidemiological methods for investigating wild animal reservoirs of animal disease. Rev. Sci. Tech. Off. Int. Epiz., 10: 205-14, 1991.

287-WILESMITH, J.W. \& CLIFTON-HADLEY, R.S. Tuberculosis in cats. [Letter; comment] Vet. Rec., 134: 359, 1994.

288-WILKINS, E.G.L.; GRIFFITHS, R.J.; ROBERTS, C. Bovine variants of Mycobacterium tuberculosis isolated in Liverpool during the period 1969 to 1983: an epidemiological survey. Q. J. Med., 59(230): 627-35, 1986.

289-WILLIAMS, R.S. \& HOY, W.A. The viability of B.tuberculosis (bovinus) on pasture land, in stored faeces and in liquid manure. J. Hyg. Lond., 30: 4139, 1930. 
290-WOLINSKY, E. Nontuberculous mycobacteria and associated diseases. Am. Rev. Respir. Dis., 199: 107-59, 1979.

291-WOOD, P.R.; CORNER, L.A.; PLACKETT, P. Development of a simple, rapid in vitro cellular assay for bovine tuberculosis based on the production of gama-interferon. Res. Vet. Sci., 49: 46-9, 1990.

292-WOOD, P.R.; CORNER, L.A.; ROTHEL, J.S. et al. Field comparison of the interferon-gamma assay and the intradermal tuberculin test for the diagnosis of bovine tuberculosis. Aust. Vet. J., 68: 286-90, 1991.

293-WOOD, P.R.; CORNER, L.A.; ROTHEL, J.S. et al. A field evaluation of serological and cellular diagnostic tests for bovine tuberculosis. Vet. Microbiol., 31: 71-9, 1992.

294-WOOD, P.R. \& ROTHEL, J.S. In vitro immunodiagnostic assays for bovine tuberculosis. Vet. Microbiol., 40: 125-35, 1994.

295-WORLD HEALTH ORGANIZATION. Report of the Who meeting on zoonotic tuberculosis (Mycobacterium bovis) with the participation of FAO. Geneva, 1993.

296-WORLD HEALTH ORGANIZATION. Zoonotic tuberculosis (Mycobacterium bovis): memorandum from a WHO meeting with the participation of FAO. Bull. World Health Organ., 72: 851-7, 1994.

297-YATES, M. D. The differentiation and epidemiology of the tubercle bacilli and a study into the identification of certain other mycobacteria. London, 1984. [Thesis submitted for the degree of Master of Philosophy].

298-YATES, M.D. \& GRANGE, J.M. Incidence and nature of human tuberculosis due to bovine tubercle bacilli in south-east England: 1977-1987. Epidemiol. Infect., 101: 225-9, 1988. 
299-ZACARÍAS, F.; GONZÁLES, R.S.; CUCHÍ, P. et al. HIV/AIDS and its interaction with tuberculosis in Latin America and the Caribbean. Bull. Pan. Am. Health Organ., 28: 312-23, 1994.

300-ZAKI, M.H. \& HIBBERD, M.E. The tuberculosis story: from Koch to the year 2000. CADUEUS, 12: 43-60, 1996.

301-ZANON, U.; MAGARÃO, M.F.; MONDIM, E.L. Atividade tuberculicida de desinfetantes hospitalares. Rev. Div. Nac. Tuberc., 18(69): 5-15, 1974.

302-ZOMBORSZKY, Z.; KÖRMENDY, B.; TUBOLY, S. et al. The value of immunodiagnostic tests in detecting tuberculosis in an infected red deer herd and in eradication of the disease by selection. Acta Vet. Hung., 43: 385-92, 1995. 